\title{
WestVirginiaUniversity
}

THE RESEARCH REPOSITORY @ WVU

Graduate Theses, Dissertations, and Problem Reports

2001

\section{Dutch women in New Netherland and New York in the seventeenth century}

\author{
Michael Eugene Gherke \\ West Virginia University
}

Follow this and additional works at: https://researchrepository.wvu.edu/etd

\section{Recommended Citation}

Gherke, Michael Eugene, "Dutch women in New Netherland and New York in the seventeenth century" (2001). Graduate Theses, Dissertations, and Problem Reports. 1430.

https://researchrepository.wvu.edu/etd/1430

This Dissertation is protected by copyright and/or related rights. It has been brought to you by the The Research Repository @ WVU with permission from the rights-holder(s). You are free to use this Dissertation in any way that is permitted by the copyright and related rights legislation that applies to your use. For other uses you must obtain permission from the rights-holder(s) directly, unless additional rights are indicated by a Creative Commons license in the record and/ or on the work itself. This Dissertation has been accepted for inclusion in WVU Graduate Theses, Dissertations, and Problem Reports collection by an authorized administrator of The Research Repository @ WVU.

For more information, please contact researchrepository@mail.wvu.edu. 


\title{
Dutch Women in New Netherland and New York in the Seventeenth Century
}

\author{
Michael E. Gherke \\ Dissertation submitted to the College of Arts and Sciences \\ at West Virginia University in partial fulfillment of the \\ requirements for the degree of \\ Doctor of Philosophy \\ in History
}
Mary Lou Lustig, Ph.D., chair Jack Hammersmith, Ph.D. Matthew Vester, Ph.D. Caroline Litzenberger, Ph.D. Martha Shattuck, Ph.D.

Department of History

Morgantown, West Virginia 2001

copyright @ Gherke, Michael E. All rights reserved. 


\section{Abstract \\ Dutch Women in New Netherland and New York in the Seventeenth Century Michael E. Gherke}

The European settlers who emigrated to America in the seventeenth century were decidedly patriarchal. Nevertheless, significant cultural differences in expressions of patriarchy among them existed. Specifically, the Dutch of New Netherland defined the gendered roles of women differently than did other European cultures. More than deputy-husbands, but less than full partners, seventeenth-century Dutch women in New Netherland were integral to the survival and promotion of their families' interests and preservation of the colony. English expropriation of New Netherland in 1664 and permanent acquisition in 1674 inaugurated a process of patriarchal acculturation that over time submerged the roles of Dutch women. However, it did not obliterate them.

Family was the basic unit in Dutch society and Dutch law in New Netherland, which mirrored the jurisprudence of Holland, reinforced family structure. Specifically, Dutch law reinforced social stability through laws affecting marriage. As an institution that came under civil law, marriage could be legally dissolved. Nevertheless, most wives appear in court records as defenders and promoters of their family's interests. Therefore, the paradox of seventeenth-century Dutch women was that while their primary roles were wives and mothers, they exercised considerable independence within marriage. Owing to the commercial orientation of New Netherland, decision making by wives was important to the viability of New Netherland and New York economy in the seventeenth century.

New Netherland was founded during the golden age of Dutch commerce. Most histories of that age have focused on transoceanic trade, but local commerce was also 
important particularly for wives. In a population drawn together in close proximity by geography, historically many wives were formally and informally involved in local commerce as shopkeepers, teachers, and occasional traders. As a consequence, young women were educated and trained early for a married life that involved commerce.

This work shows the behavior of women in New Netherland was governed by distinctive social, legal, and cultural expectations that governed the lives of Dutch women in the United Provinces of the Netherlands. Specific focus on Dutch women emphasizes the significance of the diversity of culture and gender identities in early America. 
To Shelly, David, and Rachel 


\section{ACKNOWLEDGMENTS}

I am thankful to many people for their tireless efforts in helping bring this work to fruition. Among the most important is my dissertation advisor and friend, Mary Lou Lustig. This work could not have been completed without her incisive commentaries, precise editing, and gentle nudges to finish. She personifies my ideal of a superior educator.

I am also indebted to Martha Shattuck who offered suggestions and commentary during the writing process and assistance with the peculiarities of seventeenth-century Dutch language. I am particularly thankful for her insights regarding Rachel Vinje and her husband, Cornelius van Tienhoven, her observations regarding Jeremias van Rensselaer's relationship with his mother, Anna, and for her ever present encouragement of my efforts. Chapter three of her dissertation, "A Civil Society: Court and Community in Beverwijck, New Netherland, 1652-1664," gave me a greater understanding of partnership marriage among the seventeenth-century Dutch and provided a blueprint for my study.

I am thankful for the advice and efforts of the remainder of my committee, Jack Hammersmith, Matthew Vester, and Caroline Litzenberger. They served faithfully under extraordinary circumstances.

David Voorhees' assistance was invaluable. He graciously sent me copies of letters and legal documents from the Leisler papers that enhanced my knowledge and understanding of women's roles in Leisler's Rebellion. As a consequence, I was able to 
assess women's involvement in the Rebellion from a broader cultural perspective.

There are very many people along the way whose assistance was brief but essential. Correspondence from authors like Donald Haks, Adriana van Zwieten, and archivists at the International Information Centre and Archives for the Women's Movement in Amsterdam provided valuable information that added depth to my effort.

Finally, I would be remiss by not acknowledging the assistance of many librarians and staff members at the institutional libraries where research took place. Among them are the librarians and staff at Wise Library at West Virginia University, the Ezra Lehman Library at Shippensburg University in Shippensburg, PA., and the ShadekFackenthal Library at Franklin and Marshall College in Lancaster, PA.

Most of all I want to thank my family, Shelly Hykes, my wife, and my children David and Rachel. Inasmuch as my graduate study began the same week Shelly and I were married, these dear ones have known only struggle. In particular, the sacrifices made by Shelly to see this work through to completion were greater than I can adequately describe. I pray my responsibilities for "good partnership" with her will be accomplished hereafter. 


\section{Table of Contents}

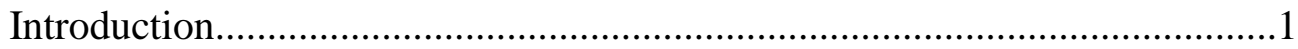

Chapter One: More than Deputy Husbands.................................................24

Chapter Two: Dysfunctional Marriages and the Transition from Dutch to English Law........................................................64

Chapter Three: Women, the Colonial Economy, and Institutional Anglicization.

Chapter Four: Women and Power in New Netherland and Seventeenth-Century New York: A Different Model of Patriarchy in Early America.

Chapter Five: The Experience of Dutch Widows in New Netherland and Seventeenth-Century New York......................................215

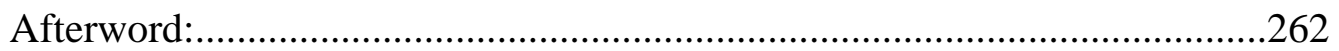

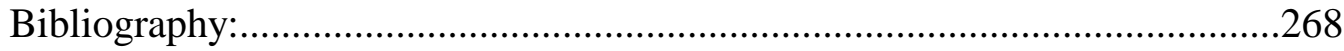




\section{Tables and Charts}

\section{Tables}

Table 1: Debt Litigation Cases Involving Women.......................................144

Table 2: Outcome of Court Decisions Involving Women............................145

Table 3: Widowed Women and Men and Their Children..............................228

Table 4: Numerical Distribution of Widows with Children.........................230

\section{Charts}

Chart 1: Percentages of Debt Litigation Cases Involving Women.................144

Chart 2: Percentages of Outcome of Court Decisions Involving

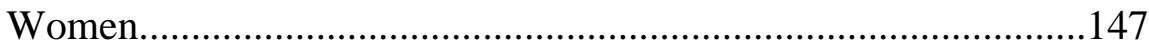

Chart 3: Percentages of Widowed Women, Men, and their Children..............228

Chart 4: Distribution of Children by Parental Sex........................................2230 


\section{Introduction}

"I may boldly say, that the women of these parts, are above all other truely taxed with this unnatural domineering over their husbands."1

Jasper Dankaerts was a Dutch member of an obscure Protestant sect known as Labadists, a group who followed the teaching of Jean de Labadie. In 1679, the sect sent Dankaerts and Peter Sluyter from Amsterdam to America to scout New York and adjacent environs for a place to begin colonization for members of the order. On June 8, 1679, they contracted with Margaret Hardenbroeck Philipse, owner of the King Charles, for passage to America. Viewed as parsimonious by Dankaerts, Philipse, who accompanied Dankaerts, other passengers, and trade goods on the King Charles, had emigrated to New Netherland twenty years earlier as a factor for her cousin, merchanttrader Wolter Valck. In New Netherland, she established herself as an astute merchanttrader who, with her second husband, Frederick Philipse, built a large family fortune. ${ }^{2}$

If Margaret Hardenbroeck was the only seventeenth-century New York woman whose actions reflected decisiveness and authority, she would be an anomaly. ${ }^{3}$ Like many elite women in many early modern European cultures, Hardenbroeck had access

${ }^{1}$ Fynes Moryson, An Itinerary containing his ten yeares travell through the twelve dominions of Germany, Bohmerland, Sweitzerland, Netherland, Denmarke, Poland, Italy, Turky, France, England, Scotland \& Ireland, 4 vols. (London, 1617; rpt. Glasgow, 1907-1908), 4: 469.

${ }^{2}$ Henry C. Murphy, ed. Journal of a Voyage to New York and a Tour in Several American Colonies in 1679-1680 by Jasper Dankers and Peter Sluyter (Brooklyn, 1867; rpt. New York, 1952), 86, [hereafter cited as Dankaert's Journal].

${ }^{3}$ Referring to married women by their patronymic was common among the seventeenth-century Dutch. 
to opportunities her poorer neighbors had neither the wealth nor leisure time to pursue.

However, it may be argued, her expressions of self-reliance as she conducted transoceanic trade was more the product of her cultural heritage than her status. The scale of involvement in commercial and other public activities by particularly married Dutch women varied according to status. Still, despite status, many did so with decisiveness and resolution.

England, the United Provinces of the Netherlands, and other western European cultures were decisively patriarchal in the seventeenth century. However, there were subtle differences in ways patriarchy was expressed in each culture. Insofar as they affected seventeenth-century America, my attention is on the differences between the patriarchal cultures of England and the United Provinces. English expropriation of New Netherland in 1664 which was made permanently legal by the Treaty of Westminster in 1674, inaugurated a process of acculturation in seventeenth-century New York. Over time, the hegemonic ascent of English patriarchy obscured Dutch patriarchal characteristics. The process was gradual owing to the reluctance of English administrators to effect wholesale changes that had potential to incite resistance among the majority Dutch population. ${ }^{4}$ Between 1664 and the early eighteenth-century,

\footnotetext{
${ }^{4}$ While the population of New Netherland was majority Dutch, the colony was comprised of immigrants from many European countries. However, many of the non Dutch had previously immigrated to the United Provinces of the Netherlands and came to New Netherland after a period of Dutch acculturation. See, Joyce Goodfriend, “"Too Great a Mixture of Nations': The Development of New York City Society in the Seventeenth Century," (Ph.D. dissertation, University of California at Los Angeles, 1975); David Steven Cohen, "How Dutch Were the Dutch of New Netherland?" New York History, 62 (January, 1981), 43-60; Oliver Rink, "The People of New Netherland: Notes on Non-English Immigration to New York in the Seventeenth Century," New
} 
characteristics of Dutch patriarchy and specifically the roles of women, were submerged by administrative, legal, and demographic changes that reflected English culture. Among the changes were increased English institutionalization of law, cultural intermarriage between Dutch and English couples, and increased English immigration. ${ }^{5}$ Nevertheless, contrary to the opinions of some historians, Dutch expressions of patriarchy were never completely suppressed by these events. Therefore, they continued to help shape the foundations of American civilization. ${ }^{6}$

Few historians have explored the cultural foundations of the activities of Dutch women in early America and how English expropriation of New Netherland affected that activity. This is particularly surprising considering the efforts of historians of Dutch-American culture to translate and publish primary records from the Dutch period

York History, 62 (January, 1981), 5-42.

${ }^{5}$ Patricia Bonomi, A Factious People: Politics and Society in Colonial New York (New York and London, 1971), 25-26.

${ }^{6}$ Firth Haring Fabend, A Dutch Family in the Middle Colonies, 1660-1800 (New Brunswick and London, 1991), traced the enduring "Dutchness" of the Haring family from the seventeenth-century to the beginning of the nineteenth-century. See also, David E. Narrett, "Dutch Customs of Inheritance, Women, and the Law in Colonial New York City," in William Pencak and Conrad Edick Wright, eds. Authority and Resistance in Early New York (New York, 1988), 27-55: 29, who provided a detailed analysis of wills that showed the persistence of Dutch customs of inheritance. Bonomi, A Factious People, 28-29, placed part of the reason for persistence of Dutch customs on the failure to establish representative government in New York that resulted in intense localism. See also, Goodfriend, Before the Melting Pot: Society and Culture in Colonial New York City, 1664-1730 (Princeton, 1992), 13; Sung Bok Kim, Landlord and Tenant in Colonial New York: Manorial Society, 1664-1775 (Chapel Hill, 1979), 5. Bok maintained Dutch society was never firmly established, which is a position with which I disagree. David Hackett Fischer, Albion's Seed: Four British Folkways in America (New York, 1989), is well known for its marginalization of non-English cultures in early America. 
of New York history. Unlike particularly court records of American colonies founded by English immigrants, the public records of the Dutch in New Netherland reflect intense commercial and social activity by Dutch women. Civil litigation by Dutch women was so frequent in New Netherland that their appearance in court records was commonplace. However, an important characteristic of women's court appearances was they acted from responsibility they acquired in their roles as wives and mothers. Nevertheless, the perception Dutch wives' public appearances were solely as adjuncts for interests that were primarily the responsibility of their husbands is untenable. ${ }^{7}$

Among the requirements for investigating the lives of part women is a willingness to challenge accepted opinions, pursue innovative topics, and research underused or overlooked sources. If, as Abigail J. Stewart maintains, studying women means

"choosing individual women-who were, by definition, always less 'important' than male counterparts-as worthy of study,"

and,

"that in our studies of women we define as 'important' we look for what has been overlooked, unconceptualized, and not noticed, but may be very

${ }^{7}$ Martha Dickinson Shattuck, "A Civil Society: Court and Community in Beverwijck, New Netherland, 1652-1664," (Ph.D. dissertation, Boston University, 1993), 156. Chapter three, "Wives, Mothers, and Businesswomen," 140-191, of "A Civil Society" and the author's personal encouragement of my efforts inspired my belief a more thorough investigation of Dutch women in New Netherland and seventeenthcentury New York could be accomplished and possibly add to greater academic appreciation for the influences of Dutch culture on early New York. 
central to women's experience,"»

then leaving Dutch women out of the experience of early American women lessens the accuracy and therefore, the vibrancy of early American history.

The reasons for neglect of the Dutch in early American historiography include marginalization that precedes Anglocentrism. There are several reasons for neglect of the Dutch by historians of early American history. Among them is the brevity of Dutch rule of New Netherland compared with English rule of New York and other North American colonies. Dutch political control of New Netherland last from the early 1620s to 1664. Second, unexplored presumptions about Dutch administration of New Netherland exist. Specifically, rule by the Dutch West India Company and absence of a formally established representative assembly are viewed as antithetical to the character of American cultural development. ${ }^{9}$

Another reason for Dutch marginalization is the difficulties presented by a

${ }^{8}$ Carol E. Franz and Abigail J. Stewart, eds. Women Creating Lives: Identities, Resilience, and Resistance (Boulder, Sand Francisco, and Oxford, 1994), 14.

${ }^{9}$ Goodfriend, “The Dutch Colonial Legacy: 'Not Hasty to Change Old Habits for New'," de Halve Maen, 65 (Spring, 1992), 5-9; "Writing/Righting Dutch Colonial History," New York History, vol. 80, no. 1 (Jan., 1999), 5-28. Some of the most egregious examples of marginalization of the Dutch exists among historians of New York colonial history. John Fiske, The Dutch and Quaker Colonies in America, 2 vols. (Boston, 1901); Albert E. McKinley, "The English and Dutch Towns on New Netherland," American Historical Review, no. 6 (1900), 1-18; Sung Bok Kim, Landlord and Tenant in Colonial New York, Thomas J. Condon, New York Beginnings: The Commerical Origins of New Netherland (New York, 1968). Condon wrote, "Institutional forms planted in New Netherland were ephemeral things which never acquired any real definition throughout the Dutch period [119]." Deborah A. Rosen, "Mitigating Inequality: Women and Justice in Colonial New York," in Larry Eldridge, ed. Women and Freedom in Early America (New York and London, 1997), 313-329. 
polyglot population that does not fit the models of English settlement in New England and the Chesapeake. That is, although the non Dutch population of New Netherland was influenced by predominant Dutch culture, their origins complicate methodologies for investigating early American women. ${ }^{10}$ Specifically, investigating the subtleties of cultural diversity increases the need for investigating the cultural origins of New York residents. ${ }^{11}$

Assignment of the Dutch to irrelevancy has allowed historians of early American women to ignore the experience and lasting influence of Dutch women. One of the most recent examples is an anthology of early American women that Linda Kerber and Jane Sherron De Hart edited. Referencing the Louisiana purchase in the introduction to chapter one, the editors recognized the community property component of marriage under Spanish and French law. However, they failed to mention community property governed Dutch marriages in New Netherland in the seventeenth century. ${ }^{12}$

${ }^{10}$ This theory about neglect of the middle colonies and New York in particular was advanced by Milton Klein, "New York in the American Colonies: A New Look," in Jacob Judd and Irwin H. Polishook, eds. Aspects of Early New York Society and Politics (Tarrytown, N.Y., 1974), 8-28; Bonomi, A Factious People, 3-5, traced generalizations of New York pre-Revolutionary history to Carl Becker, The History of Political Parties in the Province of New York, 1760-1776 (Madison, Wis., 1909), chapter one. Becker's generalizations may have also influenced subsequent historians of New York social and economic history.

${ }^{11}$ In correspondence with Donald Haks, author of Huwelijck en Gezin in Holland in de 17de and 18de eeuw [Marriage and Family in Holland in the Seventeenth and Eighteenth Century], (Assen, 1982), Haks lamented the lack of communication and cooperation between European and American historians.

${ }^{12}$ Linda K. Kerber and Jane Sherron De Hart, eds. Women's America: Refocusing the Past (New York, 1995), 26. 
More often, Dutch women are given token inclusion in histories of early

American women. For example, Carol Berkin's 1996 work, First Generations: Women in Colonial America, exploration of Dutch women was restricted to commentary about Margaret Hardenbroeck. ${ }^{13}$ Hardenbroeck was an important woman in New Netherland and therefore early America, but her elite status was not indicative of most Dutch women. Deborah A. Rosen's article, "Mitigating Inequality: Women and Justice in Colonial New York," failed to recognize Dutch legal influence on women's recourse to equity justice in eighteenth-century New York. ${ }^{14}$ Submission of disputes to arbiters was an important feature of Dutch legal administration. Marylynn Salmon's Anglocentric focus on early American intestacy laws in her 1986 work that investigated women and property led her to ignore valuable information about Dutch women. She briefly reflected on David E. Narrett's work on New York will that showed sexual equality in property divisions, but did not elaborate on the legal implications of the Dutch practice. Owing to her reverence for the diversity of early American law, this is an interesting omission. $^{15}$

${ }^{13}$ Carol Berkin, First Generations: Women in Colonial America (New York, 1996), 79-87.

${ }^{14}$ Deborah A. Rosen, "Mitigating Inequality: Women and Justice in Colonial New York," in Larry D. Eldridge, ed. Women and Freedom in Early America (New York, 1997), 313-329. See also, Rosen's, Courts and Commerce: Gender, Law, and the Market Economy in Colonial New York (Columbus, OH., 1997).

${ }^{15}$ Marylynn Salmon, Women and the Law of Property in Early America (Chapel Hill, 1986), 142. David Narrett's efforts on New York wills are well known to historians of New Netherland and seventeenth-century New York. Some of his conclusions are revealed in, "Patterns of Inheritance in Colonial New York City, 16641775: A Study in the History of the Family," (Ph.D. dissertation, Cornell University, 
Historians who have investigated women in seventeenth-century Dutch culture in America recognized differences with early American English culture. The most important work to recognize the differences was Linda Biemer's 1979 study of the effects of English expropriation on Dutch women's proprietary interests. ${ }^{16}$ However, after a brief background on the differences between Dutch and English law in regard to women, the work was biographical with focus on elite women. The work's failure to investigate early American Dutch women along a broader social spectrum left room for further investigation. The gaps left by Biemer have been partially filled by authors who presented their work in articles and dissertation chapters. Shattuck's chapter, "Wives, Mothers, and Businesswomen," of her 1993 dissertation is a significant contribution to the historiography of early American Dutch women. By relating the legal and cultural foundations of Dutch women's activities in Beverwijck, New Netherland, Shattuck set the scene for contrasts with Anglo-American culture. ${ }^{17}$

Building on Shattuck's work, David Voorhees' 1997 article on women in

1981); Inheritance and Family Life in Colonial New York City (Ithaca, N.Y., 1992); "Men's Wills and Women's Property Rights in Colonial New York," in Ronald Hoffman and Peter J. Albert, eds. Women in the Age of the American Revolution (Charlottesville, VA., 1989), 91-133; "Dutch Customs of Inheritance, Women, and the Law in Colonial New York City," in Pencak and Wright, eds. Authority and Resistance, 27-55. Relegation of Dutch law to the periphery owing to English expropriation of New Netherland is also seen in, Lawrence M. Friedman, A History of American Law (New York, 1973), 19; Peter Charles Hoffer, Law and People in Colonial America (Baltimore and London, 1992), 28-29.

${ }^{16}$ Linda Biemer, Women and Property in Colonial New York: The Transition from Dutch to English Law, 1643-1727 (Ann Arbor, MI., 1983).

${ }^{17}$ Shattuck, “A Civil Society,” chapter 3: 140-191. 
Leisler's Rebellion showed ways traditional Dutch definitions of gender influenced women's active participation in the event. He wrote, "The independent nature of New York's women was a direct result of the province's Dutch legal and cultural heritage."18 He further developed a convincing hypothesis that Dutch women's roles in the rebellion were partly due to erosion of their economic and legal independence resulting from English cultural ascendance. ${ }^{19}$

Also building on the work of Shattuck, Adriana van Zwieten's recent article reveals the intensity with which Dutch women in New Netherland participated in the economic and social life in the colony as a whole. ${ }^{20}$ Like Shattuck, van Zwieten focused exclusively on the Dutch period and therefore, did not reflect on the changing status of women in the late seventeenth and eighteenth centuries.

My effort builds upon the work of Shattuck, van Zwieten, Narrett, and the aggregate body of work presented on New Netherland and New York in the seventeenth century. Women had broad responsibilities in seventeenth-century Dutch society that required them to represent themselves and their families in public venues like court and the marketplace. Consequently, they appear in public records with uncommon

${ }^{18}$ Voorhees, “'how ther poor wives do, and are delt with': Women in Leisler's Rebellion," de Halve Maen, 70 (Summer, 1997), 41-48.

${ }^{19}$ Ibid., 42-43. Edwin G. Burrows and Mike Wallace, Gotham: A History of New York City to 1898 (New York, 1999), 93, made the assertion a 1684, "Act for Quieting Men's Estates," that eroded married women's legal independence contributed to their involvement in Leisler's Rebellion.

${ }^{20}$ Adriana van Zwieten, “'[O]n her woman's troth': Tolerance, Custom, and the Women of New Netherland," de Halve Maen, vol. 55, no. 1 (Spring, 1999), 3-14. 
frequency. Exploration of the lives of Dutch women in early America is important for two reasons. First, it reveals the paradoxical character of seventeenth-century Dutch society in America. Wife and mother were the primary roles open to Dutch women in Europe and America in the seventeenth century. Nevertheless, women were required to carry out duties associated with law and commerce that placed them in public arenas.

Second and more significantly, investigating the lives of Dutch women in New Netherland and New York in the seventeenth century provides opportunities for exploring the experiences of early American women. English women in colonial America are not completely absent from public documents like court records. However, owing to application of laws that defined married women as feme covert in most English colonies, their appearances in public forums like court went unrecorded. ${ }^{21}$ Logic dictates the conditions of colonial life in early America required English women to carry out duties aimed at survival and prosperity that were most often the prerogatives of men. Some historians of early American women have explored the vital roles, some of which placed them in public forums, played by English women. ${ }^{22}$

${ }^{21}$ Feme covert is a legal term that refers to former legal disabilities of married women under English law. It contrasts with the term, feme sole, which described the condition of unmarried women. Henry Campbell Black, Black's Law Dictionary (St. Paul, MN., 1990), 617.

${ }^{22}$ For example, Julia Cherry Spruill, "Participation in Public Affairs," Women's Life and Work in the Southern Colonies (New York and London, 1938; rpt. 1972), chapter eleven: 232-254; Laurel Thatcher Ulrich, Good Wives: Image and Reality in the Lives of Women in Northern New England, 1650-1750 (New York, 1980); Joan M. Jensen, Loosening the Bonds: Mid-Atlantic Farm Women, 1750-1850 (New Haven and London, 1986); Ruth Swartz Cowen, More Work for Mother: The Ironies of Household Technology from the Open Hearth to the Microwave (New York, 1983); Lois Green Carr and Lorena S. Walsh, "The Planter's Wife: The Experience of White Women in 
Therefore, this work does not deny the contributions of English women in early America. Nevertheless, by convention English culture and law as it was expressed in early America often denied particularly married women identification beyond their roles as wives and mothers. ${ }^{23}$ For example, when a woman in the English colonies married, she lost her individual identity as represented in loss of her name. ${ }^{24}$ Dutch women retained their patronymic when they married.

One paradox of early modern Dutch culture was, while marriage and family were the primary means of self expression by women, the responsibilities they carried out as wives and mothers often went beyond home and hearth. In July 1662, Jeremias van Rensselaer wrote to his brother, Jan Baptist. Among other news he informed Jan Baptist of his marriage to Maria van Cortlandt. In the letter, he informed his brother, "I thank the good Lord for having granted me such a good partner and we shall beseech

Seventeenth-Century Maryland," William and Mary Quarterly, $3^{\text {rd }}$ ser., no 34 (1977), 542-571; Sarah F. McMahon, "Gender, Dietary Decisions, and the Technology of Food Preservation in New England Households, 1750-1850," in Judith A. McGaw, ed. Early American Technology: Making and Doing Things from the Colonial Era to 1850 (Chapel Hill and London, 1994), 164-196; Terri Lynn Snyder, "'Rich Widows Are The Best Commodity This Country Affords': Gender Relations and the Rehabilitation of Patriarchy in Virginia" (Ph.D. dissertation, University of Iowa, 1992);

${ }^{23}$ Marylynn Salmon, "Conveyances," Women and the Law of Property in Early America, chapter two: 14-40; Kathleen M. Brown, "Gender and English Identity on the Eve of Colonial Settlement," Good Wives, Nasty Wenches, and Anxious Patriarchs: Gender, Race, and Power in Colonial Virginia (Chapel Hill and London, 1996), chapter one: 13-41. Kerber and De Hart, "Gender and the New Women's History," Women's America, 3-23: 13.

${ }^{24}$ Ulrich, Good Wives, 7. 
Him that He may let us live together long in peace and health." ${ }^{25}$ Unfortunately for Maria van Rensselaer, none of these were forthcoming.

The patroonship of Rensselaerswijck was perpetually in debt. Following the birth of her first child, named Kiliaen, on August 24, 1663, Maria contracted what historians using medical knowledge believe was septic arthritis compounded by osteomyelitis of the femur. ${ }^{26}$ She subsequently had at least four more children while married to Jeremias and was left widowed on October 12, 1674, twelve years after her marriage. ${ }^{27}$ Jeremias' death came at a particularly inopportune time for Maria.

Creditors and investors pressured her for repayment and return from the patroonship. The New Netherland Dutch regained the colony in September 1673, only to have it permanently ceded to England by Treaty in February $1674 .{ }^{28}$ Finally, after the death of Jeremias van Rensselaer, Robert Livingston devised unscrupulous machinations to

${ }^{25}$ A.J.F. van Laer, trans. and ed.. Correspondence of Jeremias van Renssearlaer, 1651-1674 (Albany, 1932), 297, [hereafter cited as CJVR]. Jeremias died on October 12, 1674 and, following the birth of her first child, Maria van Rensselaer was plagued by health problems for the remainder of her life. Van Laer, trans. and ed., Correspondence of Maria van Rensselaer, 1669-1689 (Albany, 1935), 16 [hereafter cited as $C M V R$ ]; Following the birth of that child, named Kiliaen, on August 24, 1663, Maria contracted what historians using medical knowledge believe was septic arthritis compounded by osteomyelitis of the femur. Peter Christoph, "'Worthy, Virtuous Juffrow Maria van Rensselaer'," de Halve Maen, vol. 70, no. 2 (Summer, 1997), 2540: 25-26.

${ }^{26}$ Peter Christoph, “'Worthy, Virtuous Juffrow Maria van Rensselaer',” de Halve Maen, vol. 70, no. 2 (Summer, 1997), 25-40: 25-26.

${ }^{27}$ CJVR, 6.

${ }^{28} \mathrm{New}$ Netherland was formally surrendered to the English on November 10, 1674. CMVR, 4. 
acquire Rensselaerswijck. ${ }^{29}$ Only someone with inordinate skill and resolve could have surmounted these difficulties.

Therefore, Jeremias van Rensselaer's comment about a good partner should not be viewed as a hyperbolic conventional expression. Instead, it serves well as a template for further investigation. Specifically, what did it mean for a Dutch wife to be a good partner? What prerequisites were necessary for a woman to be a good partner to her husband? Maria and Jeremias van Rensselaer were among the colony's elite. Did status affect a woman's ability to be a good partner? What if a wife or, a husband for that matter, was not a good partner? Could they dissolve the partnership? War marital partnership the only role open to women in New Netherland and New York in the seventeenth century? Finally, were marital partnership and Dutch women affected by institutional and other changes that led to English cultural hegemony? I have attempted to answer these and a host of corollary questions in this work.

My approach to investigation of these questions is eclectic, but not convoluted. Methodologically, I selected specific sociological topics that I believe show the Dutch cultural foundations of Dutch women's experience in New Netherland and New York in the seventeenth century. Secondarily, I show ways English appropriation of the colony affected Dutch women. Much of the effort relies on court records and other legal documents that reveal ways Dutch women interacted in their families and communities. Many works about early American women rely heavily on a formal body of law, court

\footnotetext{
${ }^{29}$ Ibid., 117, 118, 125-126, 156.
} 
records, wills, and other legal documents to establish and reinforce their theses. ${ }^{30}$ In that respect, my effort is not different. However, although seventeenth-century RomanDutch law forms a background for my research, the application of laws as recorded in court minutes and other records provides evidence for my conclusions. I have relied heavily on seventeenth-century Dutch jurist, Hugo Grotius [Hugo de Groot], who compiled his, Inleiding tot de Hollandsche Rechtsgeleerheyd (Introduction to the Jurisprudence of Holland) between 1619 and 1621 for his son's legal instruction. ${ }^{31}$ This was the system of law applied in the northern provinces of Holland and Friesland. Referred to as "laws of the fatherland" in seventeenth-century court minutes, this body of law formed the basis for adjudication in New Netherland. ${ }^{32}$ Reference to Dutch jurisprudence is particularly important owing to use of Dutch legal forms and laws after English expropriation of New Netherland. Continuation of Dutch practices must have seemed expedient to English administrators governing a population accustomed to Dutch jurisprudence and language. As a result, introduction of English jurisprudence to

${ }^{30}$ Salmon, Women and the Law of Property, xii.

${ }^{31}$ R.W. Lee, trans. The Jurisprudence of Holland (Oxford, 1926), preface. Although referred to as Roman-Dutch law since the seventeenth-century, the laws of the United Provinces of the Netherlands were a combination of Roman law, Germanic customs, and local adaptations. The legal combination was systematized in the seventeenth century and applied in the provinces of Holland and Friesland. Biemer, Women and Property in Colonial New York, 1.

${ }^{32}$ See for example, Berthold Fernow, ed. "Minutes of the Court of Burgomasters and Schepens, 1653-1655," Records of New Amsterdam, From 1664-1674, 7 vols. (New York, 1857; rpt., Baltimore, 1976), 1: 273, [hereafter cited as RNA], in which a case concerning Isaak Greveraet mentioned reference to "the Custom and written law of the Fatherland." 
the colony was did not occur uniformly throughout the colony. A hybrid system of jurisprudence was created in which some aspects were Dutch and Puritan, while others had elements of common, equity, and ecclesiastical law. ${ }^{33}$ As confusing as this is for modern historians, at times it proved highly inconvenient to litigants and judicial authorities in seventeenth-century New York. $^{34}$

The five chapters that follow topically reveal the experience of seventeenthcentury Dutch-American women and offer a different model for patriarchy in early America. I relate their activities to their Dutch cultural foundations and reveal some ways English acquisition imposed different cultural standards through institutional change. Dutch women in New Netherland and New York in the seventeenth century viewed domestic roles and functions in society differently than did many seventeenthcentury English women. At the heart of Dutch women's self-concept were cultural traditions seventeenth-century English travelers to the Netherlands did not care to understand. Those traditions were shaped by history and influenced by religious, political, and economic events in early modern European history.

Chapter one develops the cultural foundations of wives' domesticity as defined

\footnotetext{
${ }^{33}$ Friedman, A History of American Law, 44-45; Herbert Alan Johnson, "The Advent of Common Law in Colonial New York," in George A. Billias, ed. Selected Essays: Law and Authority in Colonial America (Barre, MA., 1965), 74-91: 75; "The Prerogative Court of New York, 1686-1776," in Johnson, Essays on New York Colonial Legal History (Westport, CT., and London, 1981), 55-105: 56; Julius Goebel, Jr., "The Courts and the Law in Colonial New York," in David H. Flaherty, ed. Essays in the History of Early American Law (Chapel Hill, 1969), 245-277: 255.

${ }^{34}$ For example, Dutch jurists were unaccustomed to jury trials, which English administrators insisted on and introduced with the Duke's Laws. Johson, "Advent of Common Law," 81.
} 
by the Dutch. Marriage and motherhood were as central to Dutch women in early modern Europe and America as they were to women in other European cultures. Nevertheless, gender was defined differently for Dutch women than it was for women in other early modern Western European cultures that influenced seventeenth-century America. Most Dutch women were wives and mothers, but their responsibilities and opportunities in those roles went far beyond their homes, into the marketplace, court, and abroad. Gender for seventeenth-century Dutch wives in Europe and America is a study in contradictions because seventeenth-century Dutch culture was contradictory. Marriage and children were often centers of life for Dutch wives, but they were not merely adjuncts to their husbands nor did they suffer anonymity. They could not have executed duties beyond home and hearth without independent decision making ability.

Most Dutch women in Europe and America were trained for the domestic and non domestic duties of marriage and motherhood through cultural examples set by their mothers and grandmothers. Wills and other New Netherland records clearly show formal education, particularly reading and keeping accounts, of daughters was important to parents. However, instruction in skilled crafts associated with domesticity like knitting and sewing appears frequently. Therefore, from an early age many Dutch women in Europe and America were instructed in the curious dichotomy of domestic and public responsibilities they would need as wives and mothers. ${ }^{35}$

\footnotetext{
${ }^{35}$ Owing to mixed evidence from primary records, there is a healthy debate among historians about the importance of formal education for girls in the seventeenthcentury Netherlands. However, given the importance of religion in the lives of seventeenth-century Netherlanders, historical links between religion and formal education, and the influence of mothers on particularly young children, at least an ability
} 
Chapter two explores the history of marital discord and legal dissolutions of marriages in New Netherland and seventeenth-century New York. As with other aspects of seventeenth-century Dutch culture, attitudes toward irreconcilable differences in marriage were ambiguous. The early modern period in Europe was an age in which marriage was intimately attached to religion, Protestant and Catholic. For example, in England marital litigation was the prerogative of ecclesiastical courts. The Protestant Reformation in the United Provinces lessened the grip of ecclesiastical authorities over marriage, but not much. While minor details changed, the most significant alteration from Catholicism was that marriage was no longer considered a sacrament. ${ }^{36}$ One of the most important consequences of this change was that while the Reformed Church could not grant marital dissolutions, civil magistrates could. Clergymen (and the courts for that matter) worked diligently to repair dysfunctional marriages. However, if church officials could not mend differences in marriages, they sent irreconcilable couples to magistrates for dissolutions.

Dutch dissolution of marriage presented a problem for English authorities who assumed control of New Netherland in 1664 and again in 1674. The Anglican Church had legal prerogative over marriage and no ecclesiastical courts existed in colonial

to read (the Bible and religious exigeses) may have been very important for young women in the United Provinces. See, A.T. van Deursen, "Upbringing," Plain Lives in a Golden Age: Popular culture, religion, and society in seventeenth-century Holland (Cambridge, 1991), chapter eight: 115-133.

${ }^{36}$ Manon van der Heijden, "Secular and Ecclesiastical Marriage Control: Rotterdam, 1550-1700," in Anton Schuurman and Pieter Spierenburg, eds. Private Domain, Public Inquiry, Families and Life-Styles in the Netherlands and Europe, 1550 to the Present (Hilversum, 1996), 39-60: 42. 
America. Therefore, governors assumed responsibility for deciding dissolution cases. Among other assertions in this chapter, I challenge accepted opinions about the role of Dutch precedent in English governor's decision to grant dissolutions.

However, this chapter also reinforces the importance of marriage among the early modern Dutch in Europe and America. Legal separations and divorces occurred in the United Provinces, New Netherland, and in seventeenth-century New York, but they were rare. Although marriage was not longer a sacrament in the Protestant United Provinces, marriage and the family connections marriages created were too important to the social order to allow indiscriminate dissolutions. Like women in other European cultures, the primary avenue of financial security and economic advancement for Dutch women was marriage. This may be one reason some wives tolerated behaviors in their husbands that would be unacceptable in the twentieth-century.

Chapter three is an investigation of women's commercial involvement in the economy of New Netherland and ways institutional changes created by the English expropriation affected their commercial activity. Deborah A. Rosen explained the decline of women's involvement in the economy of eighteenth-century New York, but failed to recognize the Dutch foundations of their activity in trade. ${ }^{37}$ This study explores ways Dutch women in the seventeenth century influenced the prosperity of their families and the colonial economy through active involvement in trade and other commercial endeavors. During the Dutch period women were given greater legal latitude to protect and advance the financial interests of their families. Women overall and wives in

\footnotetext{
${ }^{37}$ Rosen, Courts and Commerce.
} 
particular frequently represented their families as defendants and plaintiffs in debt litigation and other civil suits.

In chapter four, I explore expressions of power by Dutch women in New Netherland and New York in the seventeenth century. Defined as self determination and ability to purposefully influence the actions of others, expressions of power by women took several forms in New Netherland and New York in the seventeenth century. Expressions of power by elite women were more prevalent, but often more subtle. When women like Maria van Rensselaer displayed uncommon hospitality to English governors, an implied reciprocal identification based on status was expressed. ${ }^{38}$ It also implied social intimacy that could result in tangible expressions of gratitude. However, elite status had limits on influence. In 1677, Margaret Hardenbroeck Philipse petitioned Sir John Werden, secretary to James, duke of York, to have a Dutch ship she intended to purchase declared an English ship. Werden, on behalf of the duke, refused her request owing to, "strict orders of late prohibiting any of those practices though frequent heretofore." ${ }^{39}$ Nevertheless, Werden recognized the relationship based on status between Philipse and Governor Edmund Andros and informed him he had, "diswaded her from it all I could." 40

Elite women in seventeenth-century New York, particularly those like Maria van

${ }^{38} \mathrm{CMVR}, 11,123$.

${ }^{39}$ E.B. O'Callaghan, trans. Documents Relative to the Colonial History of the State of New York, 11 vols. (Albany, 1853; rpt. 1969), 3: 246-247, [hereafter cited as $N Y C D$ ]. See, Shattuck, "A Civil Society," 2n2, for commentary on these documents.

${ }^{40}$ Ibid., 247. 
Rensselaer and Margaret Hardenbroeck Philipse, found ways to adapt to institutional changes brought by English acquisition. One way they did so was traditionally Dutch. They used family affiliations. Maria van Rensselaer's brother, Stephanus van Cortlandt, who helped administer Rensselaerswijck after the death of Jeremias and his brother, Nicolas, was a member of the governor's council as was Margaret Philipse's husband, Frederick. Nevertheless, latent resentment of women's changing status may have contributed to their participation in Leisler's Rebellion. ${ }^{41}$

Leisler's Rebellion occurred in 1689-1691, in response to the Glorious Revolution in England and social, religious, economic, and ethnic tensions in New York. Historians widely disagree about the ratio of these elements in bringing about the Rebellion, but other facts are well known. ${ }^{42}$ Jacob Leisler, a German and staunch Calvinist by birth, emigrated to New Netherland in 1659 as a Dutch-English translation expert for the Dutch West India Company (WIC). ${ }^{43}$ In subsequent years, Leisler

\footnotetext{
${ }^{41}$ Burrows and Wallace, Gotham, 93; Voorhees, “"how ther poor wives do, and are delt with'."

${ }^{42}$ Jerome R. Reich, Leisler's Rebellion: A Study of Democracy in New York, 1664-1720 (Chicago, 1953); Bonomi, A Factious People, 76; David S. Lovejoy, The Glorious Revolution in America (New York, 1972), 98-121; 276-277, 360-361; J.M. Sosin, English America and the Revolution of 1688: Royal Administration and the Structure of Provincial Government (Lincoln, NB., 1982), 112-113; John M. Murin, "English Rights as Ethnic Aggression: The English Conquest, the Charter of Liberties of 1683, and Leisler's Rebellion in New York," in Pencak and Wright, Authority and Resistance, 56-94: 56-58; Voorhees, "Leisler's Pre-1689 Biography \& Family Background," de Halve Maen, vol. 62, no.4 (December, 1989), 1-7; Christoph, "Social and Religious Tensions in Leisler's New York," de Halve Maen, vol.67, no.4(Winter, 1994), 87-92.

${ }^{43}$ Voorhees, "Leisler's Pre-1689 Biography," 3; Murrin dates Leisler's arrival to 1660. "English Rights as Ethnic Aggression," 67.
} 
prospered as a merchant and militia captain. In 1689, in the absence of Governor Edmund Andros and rapid exit of after that of Lieutenant-Governor Francis Nicholson, Leisler and a group of supporters assumed authority of the colony in the name of William of Orange, the new monarch of England. ${ }^{44}$ His administration was difficult owing in part to pockets of opposition from various groups in New York City and other geographic areas of New York. When Leisler surrendered the colony to Colonel Henry Slaughter, sent from English to assume authority, in 1691, anti-Leislerians like Nicholas Bayard were reinstated on the Governor's Council. They subsequently brought about Leisler's trial and execution. ${ }^{45}$

Leislerian and anti-Leislerian women were overtly and subtly involved in events that brought Leisler to a position of authority and those that led to his demise.

However, as with most activities involving women in their contacts beyond their homes, their participation in Leisler's Rebellion was expressed through traditional Dutch cultural and social channels. Family relationships and social connections were more important to women involved in the Rebellion than political and ethnic identifications. Some wives, like Judith [Judick] Verleth, wife of Nicholas Bayard, who vehemently opposed Leisler, had begun adjusting to English administration through connections associated with her elite status. She deeply resented Leisler and worked with her

\footnotetext{
${ }^{44}$ Charles Andrews, ed. "A Modest and Impartial Narrative, Introduction," Narratives of the Insurrection, 1675-1690 (New York, 1915; rpt., 1959), 317-354: 317319.

45'“Instructions for Colonel Slaughter, Governor of New York," NYCD, 3: 685691.
} 
husband against him.

Chapter five explores the realities of the lives of widows in New Netherland and New York in the seventeenth century. The experiences of Dutch widows in New Netherland and New York in the seventeenth century were similar to those of others in the American colonies. Marriage and motherhood were primary, child mortality was high, and widowhood and remarriage occurred often. However, the uncommon responsibilities expected of particularly Dutch wives and requisite skills and training to carry them out efficiently gave Dutch women advantages when they became widowed. Many responsibilities of marriage and motherhood were similar or the same for Dutch women as they were for women living in colonies founded by the English.

Nevertheless, responsibilities of marriage that included family financial management, entrepreneurship, and representing their families' interests in court, enabled many Dutch widows to function without male assistance. Widowhood was an extraordinarily difficult period for some Dutch widows, but the education, skills, and experiences they acquired earlier in life made the loss of their partner less onerous than it might have been otherwise.

Marriage and motherhood formed the primary raison d'etre for Dutch women in New Netherland and New York in the seventeenth century. Consequently, in that respect their lives were very similar to those of women of other cultures in early America and Europe. Nevertheless, for many Dutch women domesticity represented duties that women in many other cultures did not experience. To carry out those duties, Dutch women received education and experiential training that enabled them to exercise 
their uncommon responsibilities efficiently. In many early modern European cultures, those duties and requisite knowledge to accomplish them were most often associated with males. Compared with the aggregate number of women in early America, the number of Dutch women in New Netherland and New York in the seventeenth century was small. Nevertheless, owing to Dutch women's enhanced responsibilities, particularly in marriage, seventeenth-century New Netherland and New York records offer uncommon opportunities to explore the experience of colonial women. 


\section{Chapter One}

\section{More Than Deputy Husbands}

"They testify, that they give to each other, out of their love as married people, all the proceeds and benefits from all property ... they mutually trust each other and are sure, that the survivor will not defraud his or her children."1

On February 17, 1663, Maritie Jans Joncke [Joncker] gave a detailed inventory of assets and liabilities attached to her estate to notary public Walewyn van der Veen. She was very specific about the people and amounts owing to her and for which she was indebted. Specificity was important because, "in childbed and sick a-bed of the children's pocks," following the birth of her third child, a daughter, Maritie was preparing for her death. Predictably, the next document in the record was her will. In it she made provisions for the welfare of her children, but following Dutch practice made no distinctions based on sex for the care of her two sons and infant daughter. Perhaps she had little confidence in the chances for survival of a motherless new-born; infant

1"Will of Juriaen Blank and Tryntie Klaessen, August 21, 1663,” Berthold Fernow, trans. and ed., Minutes of the Orphanmaster's Court of New Amsterdam, 16521663, 2 vols. (Albany 1907), 2: 20. 
deaths were common in early America under the best conditions. ${ }^{2}$ Nevertheless, these were legal documents and her thoughts about such things went unrecorded. More generally, however, the information in the documents reveals a wife who was a careful and knowledgeable administrator of property she and her late husband accumulated. Furthermore, it shows a mother concerned about the future for what she thought were her soon to be orphaned children. ${ }^{3}$ Moreover, skillful management of her family's financial and legal affairs by Maritie Jans Joncke was common for Dutch wives in New Netherland and seventeenth-century New York. ${ }^{4}$

The duality of responsibilities implied by Maritie Jans Joncke's inventory and will reveals features of marriage unique to the Dutch and others common to most European cultures in early America. When Dutch marriages worked well, spouses in seventeenth-century Dutch society in the Netherlands and America acted as consorts. Each spouse assumed responsibilities as necessary to provide family cohesion and social

${ }^{2}$ John Demos, "Demography and Psychology in the Historical Study of Family Life: A Personal Report," in Peter Laslett and Richard Walls, eds. Household and Family in Past Time (Cambridge, 1972), 566; Lois Green Carr and Lorena Walsh, "The Planter's Wife: The Experience of White Women in Seventeenth-Century Maryland," William and Mary Quarterly, vol 34, no. 4 (October, 1977), 552 [hereafter cited as $W M Q]$; Adriana E. van Zwieten, “' $\mathrm{O}[\mathrm{n}]$ her woman's troth': Tolerance, Custom, and the Women of New Netherland," de Halve Maen (Spring, 1999), 12-13; for contravening evidence regarding infant mortality in specific early American communities see, Philip J. Greven, Jr. "Family Structure in Seventeenth-Century Andover, Massachusetts," $W M Q$, vol. 23, no. 2 (April, 1966); Barry J. Levy, “"Tender Plants': Quaker Farmers and Children in the Delaware Valley, 1681-1735," Journal of Family History, vol. 3, no. 2 (Summer, 1978).

${ }^{3}$ Maritie survived the illness; Van Zwieten, “'O[n] her woman's troth',” 4.

${ }^{4}$ Maritie Jans Joncke's will is recorded in, Fernow, Minutes of the Orphanmaster's Court of New Amsterdam, 2: 34-38. 
conformity through pursuit of personal and normative goals and values. But, that was the ideal Dutch marriage. In practice, Dutch wives assumed a significant share of responsibilities in marriage. Application of partnership among early modern Dutch couples often imposed domestic and nondomestic responsibilities upon wives. More than deputy-husbands but collectively recognized for domestic achievements, many wives balanced household work with duties requiring extra time, talents, knowledge, and frequently absence from home. ${ }^{5}$ In the Netherlands and among the seventeenthcentury Dutch in America, women lived in a patriarchal culture that limited their roles to wives and mothers. However, the dichotomy of domestic and nondomestic responsibilities experienced by Dutch wives reflected flexibility in gender roles in marriage that went beyond legal and religious proscriptions. ${ }^{6}$ Consequently, the enhanced responsibilities of many Dutch women and opportunities arising therefrom were unlike those experienced by most women in seventeenth-century Europe and America. $^{7}$

${ }^{5}$ Dankaert's Journal, 318; as applied here, the concept of deputy-husband is as described by Laurel Thatcher Ulrich, "Deputy-Husbands," Good Wives, chapter 2: 3550; the activities of Dutch women prior to the English expropriation of New Netherland, are described in Shattuck,"Wives, Mothers, and Businesswomen," "A Civil Society," chapter 3: 140-191.

${ }^{6}$ David G. Hackett, The Rude Hand of Innovation: Religion and Social Order in Albany, New York, 1652-1836 (New York and Oxford, 1991), 19-20; Biemer, Women and Property in Colonial New York, 1-6; Shattuck, "A Civil Society," 153-156.

${ }^{7}$ Susan L. Irwin, ed. and trans., Anna Maria van Schurman: Whether a Christian Woman Should Be Educated, and other writings from her intellectual circle (Chicago, 1998), 3; Kloek, "Introduction," 14; Anne Laurence, "How free were English women in the seventeenth-century," 127-135; Mary Prior, "Freedom and autonomy in England and the Netherlands: Women's lives and experiences in the seventeenth-century, A response 
Notwithstanding, flexibility in gender roles in marriage experienced by Dutch wives was an extension of their domesticity rather than an expression of their independence. After England assumed political control of New Netherland, the transition to English cultural practices affecting wives was assimilative owing partly to the continuing presence of a majority Dutch and Dutch acculturated population. ${ }^{8}$ However, particularly in domestic roles as wives and mothers, Dutch women shared with other women an acquiescence to the patriarchal underpinnings upon which social organization of western culture was based. ${ }^{9}$ More specifically, in pre-industrial patriarchal European America, Dutch and English wives shared common gender-based labor and attitudes about their roles in their respective cultures. ${ }^{10}$ However, their

to Anne Laurence, 137-140, in Kloek, Women of the Golden Age; Shattuck, "A Civil Society," 153; Sherrin Marshall, "Protestant, Catholic, and Jewish Women in the Early Modern Netherlands," in Sherrin Marshall, ed. Women in Reformation and Counter Reformation Europe (Bloomington, 1989), 127; Michael Kammen, Colonial New York: A History (New York, 1975), 91-94.

${ }^{8}$ For research on the non-Dutch population of New Netherland see, David Steven Cohen, "How Dutch Were the Dutch of New Netherland," New York History, vol. 62, no. 1 (January, 1981), 43-60; Cohen, The Dutch-American Farm (New York and London, 1992), 11-21. A small number of authors have reflected upon the effect of English cultural hegemony on wives. Biemer, Women and Property in Colonial New York, inaugurated the investigation of changes resulting from ascendance of English law, but her work focuses on a limited number of elite women. More important is David E. Narrett's exhaustive study of New York Dutch wills. See particularly, Inheritance and Family Life in Colonial New York City (Ithaca, N.Y., 1992).

${ }^{9}$ Steven Ozment, When Fathers Ruled: Family Life in Reformation Europe (Cambridge, MA., 1983); Robert Shoemaker, Gender in English Society, 1650-1850: The Emergence of Separate Spheres? (London and New York, 1998), 113-128.

${ }^{10}$ For a discussion of women's acquiescence to the patriarchal paradigm see, Gerda Lerner, The Creation of Patriarchy (New York and Oxford, 1986), 217-219; and, Shoemaker, Gender in England Society, 271. 
responsibilities in marriage differed sharply, with Dutch wives assuming duties often reserved for husbands in English society.

In addition to domesticity and patriarchy, another useful category for the study of Dutch wives in New Netherland and seventeenth-century New York is status. Like most women in early America, opportunities for Dutch women were often determined by the status of the family into which they were born and the families into which their husbands were born. Dutch women experienced social expectations imposed by the normative contours of Dutch society, but how they responded to their gendered positions was influenced by the opportunities they were afforded as a result of status. Maria van Cortlandt was seventeen when she married Jeremias van Rensselaer, director of the patroonship of Rensselaerswijck. Born into affluent New Netherland families and individually possessed of attractive qualities, van Cortlandt and van Rensselaer were judicious about their choice of a mate. For Jeremias, who unlike Maria was without benefit of parental involvement in choosing a spouse, the decision to marry Maria came only after considering her, "a year or two before, when now and then I did an errand to the Manhatans." 11 As a business associate of Maria's father, Oloff Stevensen van Cortlandt, Jeremias van Rensselaer must have had several opportunities to assess Maria's character and abilities, as she and her father did his. In a letter to his mother informing her of his marriage to Maria a month earlier, van Rensselaer related

\footnotetext{
11“Jeremias van Rensselaer to Anna van Rensselaer, August 19, 1662," CJVR, 300.
} 
he believed his bride would be a good partner. ${ }^{12}$ This was not merely hyperbole intended to influence his mother who lived an ocean away and had played no role in her son's choice of a mate. As a husband, Jeremias van Rensselaer may have desired a wife with potential to produce healthy children and who could manage common domestic duties. Nevertheless, as director of Rensselaerswijck, he also needed a partner with the requisite skills and training to assist in managing the large and often financially unstable patroonship. ${ }^{13}$

Maria van Cortlandt grew up in a society which was decidedly patriarchal, but not as circumscriptive for women as implied in the works of seventeenth-century Dutch authors like poet Jacob Cats and playwright, Gerbrand Bredero. ${ }^{14}$ However, few women in the Netherlands and New Netherland aspired to a life of independence. The centrality of family and women's roles as wives and mothers were too entrenched for most women to consider a contrary lifestyle. Even the intellectually powerful Anna Maria van

${ }^{12}$ Ibid., 300-301.

${ }^{13}$ Rensselaerswijck covered over one million acres, most of which was undeveloped. Shattuck, "A Civil Society," 48.

${ }^{14}$ Bredero and Cats were critical observers of seventeenth-century Dutch society. Cats in particular was fond of dispensing advice on the proper conduct of women. Among the works of the two authors are, Bredero, The Spanish Brabanter David Brumble, III, trans. and ed. (Binghamton, N.Y., 1982); Cats, Huwelijk [Marriage], A. Agnes Sneller, comp. (Amsterdam, 1993); Moral Emblems Richard Pigot, trans. and ed. (London, 1862); see also a Cats' excerpt addressing the conduct of women in, Thomas Heywood, Pleasant Dialogues and Dramas (London, 1637; rpt. Louvain, 1903), 203-230. Critical essays addressing the treatment of women by these authors include, Giesla van Oostveen, "It Takes All Sorts to Make a World: Sex and Gender in Bredero's Farce of the Miller," 55-64; Sneller, "Reading Jacob Cats," 21-34, in Kloek, Women of the Golden Age. 
Schuurman, whose life and career were antithetical to the images of domesticity prescribed by authors like Cats, maintained women inclined to scholarship should pursue learning for the benefit of their families. ${ }^{15}$

Most women in the Netherlands and New Netherland were conditioned in their roles as wives through education and training that started early in life. While training for the majority of young Dutch women included domestic skills, their level of formal education was often predicated upon factors like their family's occupation and affluence. ${ }^{16}$ Reared in a wealthy merchant family, Maria van Cortlandt received training and education consistent with her family's status. Her training and education was designed to make her a good partner for someone of similar status; someone like Jeremias van Rensselaer. ${ }^{17}$ Therefore, Maria's training was uncommon for many young

\footnotetext{
${ }^{15}$ Anna Maria van Schuurman (Schurman in German) was one of the most educated women in seventeenth-century Europe. A skilled and learned linguist and author, she published in Latin, The Learned Maid, or Whether a Maid May Also Be a Scholar, English ed. (London, 1659). In that work, she argued the right of women to use their intelligence. Alice Carter, "Marriage Counseling in the Early SeventeenthCentury: England and the Netherlands Compared," in Jan van Doorsten, ed. Ten Studies in Anglo-Dutch Relations (Leiden, 1974), 100. Van Schuurman fully explored affirmative and opposing arguments relating to the formal education of women in, "A Practical Problem: When the Study of Letters is Fitting for a Christian Woman," in Irwin, Anna Maria van Schurman, 25-37.

${ }^{16}$ Van Deursen, Plain Lives in a Golden Age, 115; Wayne E. Franits, Pargons of Virtue: Women and Domesticity in Seventeenth-Century Dutch Art (New York, 1993), 130.

${ }^{17}$ However, Oloff Stevensen van Cortlandt originally immigrated to New Netherland in 1637 as a soldier in the employ of the Dutch West India Company. Cohen, "How Dutch Were the Dutch of New Netherland," 48. Such a rise in wealth and status, while unusual, was not singular. Frederick Philipse, second husband of merchant-trader Margaret Hardenbroeck Philipse, came to New Netherland as a carpenter in the employ of the West India Company. His marriage to Hardenbroeck
} 
Dutch women and her education was exceptional. ${ }^{18}$

Formal education was practical as well as symbolic of status among the seventeenth-century Dutch. The fictional prostitutes, Tryn Jans and Pale An, in Bredero's satire, The Spanish Brabanter, affected refinement in their efforts to read the writing on a pawn ticket. Perhaps modeled after people encountered by Bredero on the streets of Amsterdam, the characters were from poor working class families as indicated by their start as maidservants as the age of seven. ${ }^{19}$ However, their inability to read may have been the result of a lost skill rather than one never acquired. ${ }^{20}$

While perhaps not as poor as Bredero's fictional characters, non-fictional Isabella de Moerloose was also from a working class family as affirmed by her tenure as a governess and later career as a schoolmistress. Her formal education afforded opportunities unavailable to women like the prostitutes in The Spanish Brabanter. In 1695 she became an author with publication of her autobiography entitled, Vrede Tractaet, gegeven van de hemel voor vrouwenzaet (Peace Tract: given by heaven through woman's seed). Unfortunately, the ability to read and write also provided

afforded access to the widow's substantial wealth and her acute business acumen, which he used to accumulate a sizeable fortune. That fortune is often ascribed to his efforts alone. Mary Booth, History of the City of New York, from Its Earliest Settlement to the Present Time (New York, 1858), 829; Cohen, The Dutch-American Farm, 14-15; Christoph, "Worthy, Virtuous Juffrow."

${ }^{18}$ While a record of Maria's education is non-existent, a good indication of the extent is revealed in her letters.

\footnotetext{
${ }^{19}$ Bredero, The Spanish Brabanter, act 2: 580-587, 730-780.

${ }^{20}$ Van Deursen, Plain Lives in a Golden Age, 98, 124.
} 
avenues for exploring her religious convictions. When she turned away from Reformed Christian orthodoxy and began to make her views known to her pupils, she was arrested, found guilty of teaching, "godless and abominable things," and sentenced to a term of years in the spinhuis (women's house of correction in Amsterdam). ${ }^{21}$

Women in the Netherlands who received advanced formal education were exceptional and often acquired instruction owing to special circumstances. The Visscher sisters, Anna and Maria, who showed intellectual talents at a young age, were encouraged by their wealthy merchant, poet, and social commentator father, Roemer Visscher. Previously mentioned Maria van Schuurman, whose family eventually settled in Utrecht after fleeing Cologne as religious refugees, received a university education but was required to sit behind an obstruction in which eye-holes were cut so that she might observe without being observed. Presumably, her presence was considered a potential distraction for the faculty and other students, all of whom were male and had never seen a female university student. ${ }^{22}$

The formal education of young women in New Netherland perhaps had less in common with that of women like Anna Maria van Schuurman, Anna and Maria Visscher, and even Isabella de Moerloose than with Bredero's fictional characters.

\footnotetext{
${ }^{21}$ Herman T. Roodenburg, "The Autobiography of Isabella de Moerloose: Sex, Childrearing, and Popular Belief in Seventeenth Century Holland," Journal of Social History (Summer, 1985), 518. Roodenburg described de Moerloose's status as subelite. [519]

${ }^{22}$ Schama, The Embarrassment of Riches, 408; Carter, "Marriage Counseling in the Early Seventeenth Century," 99; Mirjam De Baar, "Transgressing Gender Codes: Anna Maria van Schuurman and Antoinette Bourignon as Contrasting Examples," in Kloek, Women of the Golden Age, 145; Irwin, Anna Maria van Schurman, 4-5.
} 
Literacy levels for New Netherland and seventeenth-century New York are difficult to determine because, as in the Netherlands, schoolmasters charged per pupil fees based on levels of instruction. ${ }^{23}$ For example, Evert Pietersen charged by the quarter for each pupil, 30 stuivers, for "abc, spelling and reading," 50 stuivers for reading and writing, and 60 stuivers for reading, writing, and cyphering. ${ }^{24}$ Therefore, an important qualification about formal education for Dutch women in New Netherland and seventeenth-century New York is, that it does not necessarily follow that women who made marks rather than signatures in affirmations on public documents could not read. ${ }^{25}$

However, affirmations on public documents do reveal disparities in the level of formal education offered Dutch women and men in seventeenth-century America. In his study of Dutch schools in New Netherland and colonial New York, William Kilpatrick found 60 percent of women who affirmed information in legal documents in Albany, Flatbush, and "other portions of the colony," made marks rather than signatures. The

${ }^{23}$ Van Deursen, Plain Lives in a Golden Age, 118.

${ }^{24} \mathrm{Fernow}$, Minutes of the Orphanmaster's Court of New Amsterdam, 2: 116; In 1909 equivalents, a stuiver was worth 2 cents. Peter R. Christoph, Kenneth Scott, and Kenn Stryker-Rodda, eds. New York Historical Manuscripts: Dutch, Kingston Papers, 2 vols. (Baltimore, 1976), 2: 763, [hereafter cited as Kingston Papers]. Pietersen's charges were significantly higher than those found by van Deursen, Plain Lives in a Golden Age, 118, for Holland and Utrecht. The higher fees undoubtedly reflected competition for the services of a limited number of qualified teachers.

${ }^{25}$ Complicating any assertions about literacy rates based on signatures on public documents were people who could read and write but continued to use a mark rather than a signature. See the circumstance of Willem Fredericksz[en] Bout, in Shattuck, "A Civil Society," 59. 
percentage of men in Albany and Flatbush who could sign their names was $80 .{ }^{26}$ These percentages are reinforced by more recent similar research for other areas of the colony by Martha Shattuck and David E. Narrett. ${ }^{27}$

While statistics indicate discrepancies in the level of formal education offered women and men, some New Netherland parents valued formal education for their children and stepchildren, including daughters. Aryaentie Cornelius, a widow with six children, was required by the Orphanmaster's Court of New Amsterdam to settle the patrimony of her children prior to marriage to Albert Leendersen. Leendersen assisted Cornelius in determining the value of her assets after her husband died. Leendersen and Cornelius promised the Orphanmasters to, "bring up the six children aforesaid, to feed them, to care for them, [and] to have them taught to read and write." Most interesting about their promise was that neither Cornelius nor Leendersen could write, as revealed when they make marks rather than signatures in affirmation of the information in the document. ${ }^{28}$ Tryntie Hendricks, a widow with three children, may have been more confident about her promise to educate her children prior to marriage since, while she could not write, her fiancee, Frederick Leebersen, could. ${ }^{29}$

Affirming the domestic training of young women, pledges to educate daughters

${ }^{26}$ William Heard Kilpatrick, The Dutch Schools of New Netherland and Colonial New York (New York, 1969), 228-229. 225.

${ }^{27}$ Shattuck, "A Civil Society," 60-61; Narrett, Inheritance and Family Life, 223-

${ }^{28}$ Minutes of the Orphanmaster's Court of New Amsterdam, 1: 25-26.

${ }^{29}$ Ibid., 40-41. 
often included promises to teach domestic skills, chiefly sewing. In January 1657, Claes Pietersen Cos, a widowed parent of a daughter, desired to marry. He was required by law to settle the estate of his deceased wife, Neel Engle, on his daughter prior to his marriage to Grietie Maes. Cos satisfied the legal requirement by promising in addition to a cash amount, "to make her learn as opportunity offers, to read, write, sew and some other useful knowledge." ${ }^{30}$ Abel Hardenbroeck, brother of Margaret Hardenbroeck Philipse, finally met his legal obligation regarding his stepchildren after marriage to Annetje Meinders, by promising to provide for his wife's daughter from a previous marriage, "food, clothing, in health and sickness, to instruct her in God's Word, let her go to school, have her taught to sew and to do all, which pious and good parents are bound to do."’31

Assurances made by future spouses to satisfy legal requirements for marriage to widowed parents implies mutual acceptance of the obligations of parenthood, but in practice Dutch mothers and fathers differed in their roles as parents. Steven Ozment's study of Reformation Europe reveals parenting was too important to be left to one parent, but that individual responsibilities differed with the ages of their children. The responsibilities of fathers increased, particularly with sons, as children approached age seven. ${ }^{32}$ However, seventeenth and eighteenth century iconographic and literary evidence from the Netherlands implies intimacy between fathers and their children.

\footnotetext{
${ }^{30}$ Ibid., 28.

${ }^{31}$ Ibid., 231.

${ }^{32}$ Ozment, When Fathers Ruled, 132.
} 
This was particularly true for non-elite families. Such evidence refutes the image of parental indifference toward children sometimes associated with early modern patriarchal families. $^{33}$

However, there is little direct evidence from New Netherland that indicates emotional attachment between fathers and their young children. For example, in apparent recognition of his and his wife's respective roles in their new-born son, Kiliaen's life, Jeremias van Rensselaer wrote, "our son . . . is a beloved child to his mother and a welcome son to his father." Well aware of high infant mortality, after Kiliaen was a month old van Rensselaer dispassionately reflected, "Young Kiliaen, it seems, will abide with us, for he has already had the jaundice and the rash and is fond of suckling.,"34

Lack of supporting evidence showing attention is not necessarily proof of inattention by fathers toward their young children. However, death of adults from a variety of causes, from Indian attacks, to boating accidents, to disease, occurred frequently in New Netherland. These deaths often left children in the care of one parent. Therefore, logic dictates some fathers had responsibility for the care of young children. However, they did not always desire the obligations of being a single parent. Information gleaned from the Orphanmaster's Court of New Amsterdam records

${ }^{33}$ Lawrence Stone, The Family, Sex, and Marriage in England, 1500-1800 (New York, 1979), 82-89; Schama, The Embarrassment of Riches, 541-544; Benjamin Roberts, "Fatherhood in Eighteenth-Century Holland: The Van Der Muelen Brothers," Journal of Family History, vol. 21, no. 2 (April, 1996), 218-219; Shoemaker, Gender in English Society, 1650-1850 (London, 1998), 122-128.

${ }^{34}$ CJVR, 327, 329. 
indicates the rate of remarriage of widowed fathers was eighty-one percent while that of widowed mothers was sixty percent. ${ }^{35}$ While conclusions are tentative because most often the ages of the children went unrecorded and because the numbers in the samples are small, widowed fathers were more likely to remarry than widowed mothers. The implication is widowed fathers were less inclined to assume sole responsibility for the care of their children.

Death of a spouse and remarriage also complicated family relationships, sometimes with tragic results. Such was the circumstance with Nicolaes Langvelthuysen [Velthuysen], who married Janneke Willems, a widow with two sons, Cornelius and Hendrick de Graff. Upon the death of Willems, Langvelthuysen was incapable or unwilling to care for his stepsons. A friend of Willems, Isaak de Forest, reported to the Court of Orphanmaster's, that the younger of the two boys, presumably Hendrick, complained that his stepfather, "got drunk daily and squandered the property [of the maternal estate] and requested him [de Forest] inform the Orphanmasters.” De Forest was fulfilling a promise he made to Willems just before her death, "to keep an eye on the child." As a result of de Forest's report, the Court required Langvelthuysen to take an inventory of his deceased wife's property and make a settlement upon her children. ${ }^{36}$

\footnotetext{
${ }^{35}$ The Orphanmaster's Court of New Amsterdam required settlement of individual estates of deceased spouses when the survivor sought remarriage. A total of eleven widowed fathers were recorded, nine of whom intended to marry again. Twenty widowed mothers were recorded, only twelve of whom intended to remarry. Records of the Orphanmaster's Court, passim.
}

${ }^{36}$ Ibid., 1: 87-88. 
Langvelthuysen could not or would not follow the New Amsterdam Court's order which resulted in appointment of independent administrators to ascertain the details of Willems' estate. However, Langvelthuysen delayed turning over information required by the administrators in discovering Willems' assets. The Orphanmaster's Court of New Amsterdam subsequently on several occasions ordered Langvlethuysen to cooperate with the administrators. Rather than do so, Langvelthuysen absconded, leaving the fate of his stepsons legally to the Orphanmaster's Court. The record provides no information on Cornelius, who may have been old enough to assume responsibility for himself. However, Hendrick was hired for three years of service to New Amsterdam merchant-trader, Nicolaas Boot. ${ }^{37}$

While some fathers may have been reluctant to assume sole responsibility for the care of young children, the obligations of mothers did not end as their children aged. When ten year old Lysbet Anthony was arrested, tried, and owing to her own admission, found guilty of stealing sewant (wampum) from her employer, Elizabeth Drisius, and her landlord, Juriaanzen Becker, the magistrates ordered her mother to administer punishment. ${ }^{38}$ Ostensibly recognizing the superiority of parental authority but using it to exercise public prerogative, the court ordered the girl's mother, "To chastise her, or in

\footnotetext{
${ }^{37}$ Ibid., passim. Boot or Boodt was an inter-colonial and international merchanttrader. Fernow, RNA, 2: passim.

38، Sewan (seawan, zeewant, etc.) Wampum; strings of beads made from clam shells by the Indians, used by the settlers as scrip in the absence of hard cash. It was usually worth less than the stated value, 16 guilders in sewan being equivalent to 5 guilders in coin." Christoph, Kingston Papers, 2: 760. Elizabeth Drisius was the wife of Domine Samuel Drisius, a clergyman in the Dutch Reformed Church in New Amsterdam.
} 
case of refusal to let the same be done." Administration of punishment by the court was unnecessary because, “[Lysbet's mother] Mary, undertaking it, has with the assistance of Long Anna, severely punished and whipped her daughter in the presence of the W[orshipful] Magistrates." 39

Parents who hired out their daughters to work in the homes of wealthier neighbors sometimes placed themselves and their children at risk, albeit of different kinds. Maria Becker sued Maria Portogys for, "five and twenty guilders and five stuivers for clothes, etc. given her daughter, hired to her and gone away before her time." The decision went against Portogys who was not present at the proceeding. ${ }^{40}$ The case of Aucke Jansen's daughter was more complicated but illustrates the risks to daughters when they were hired out. It also reveals the confusion that sometimes occurred when husbands and wives shared domestic authority.

In January 1665, Assur Levy sued Balthazar Bayert [Bayard] for the return of Aucke Jansen's daughter, who had been employed by him as a maidservant and had left prior to completion of her term of service. During the proceeding it was discovered the girl had contracted to work for Bayert with the help of her father. When Levy learned about Jansen's role, he decided to bring action against him. In Levy's suit against Jansen, Jansen maintained his daughter had suffered much from Levy and further, produced a witness who testified Levy's wife had agreed Jansen could find another

\footnotetext{
${ }^{39} R N A, 3: 315$. The full names of Mary and Long Anna were not recorded.

${ }^{40}$ Ibid., 242.
} 
family to employ her. ${ }^{41}$ Neither the age of the girl nor the nature of Levy's alleged abuse were revealed in the record, but inasmuch as Levy's wife agreed to the girl's release from service she may have been suspicious or was at least uncomfortable with the presence of another women living in her home. Regardless of the nature of the abuse, Levy deferred to his wife's wishes and accepted the magistrates' ruling which, in addition to releasing the girl from service, required Asser Levy to pay her back wages and allowed her to keep the clothing he had purchased for her. Nor did Levy seek legal action against Aucke Jansen for defamation in regard to the accusation of abuse, which the magistrates specifically indicated would be heard at a later session if Levy so desired. $^{42}$

A similar action illustrative of the confusion that sometimes occurred over domestic authority within Dutch marriages was the suit of Eechie Gerrets against Jan Willemsen Hoochteylingh for wages earned by her daughter while she was in Hoochteylingh's service. Living with the Hoochteylinghs during her term of service, Gerrets' daughter returned later than expected one evening and upon knocking at the door was refused entry by Hoochteylingh's wife. ${ }^{43}$ The girl stated to her, "Mistress, then I am going to my mother to sleep." Witnesses Jacob Elemendorp and Magadelena Blanchen confirmed the event between Hoochteylingh's wife and the girl. Moreover,

${ }^{41}$ The names of the women in the case were not recorded.

${ }^{42} R N A$, 5: 176-177, 191-192.

${ }^{43}$ Neither the name of Gerrets' daughter nor Hoochteylingh's wife were recorded. 
according to another witness, Cornelius Hoogeboom, the following day Eechie Gerrets visited the Hoochteylingh's residence to inquire about her daughter's status.

Hoogeboom reported that while Mr. Hoochteylingh was willing to keep Gerrets' daughter in their employ, his wife was not. Further, Mr. Hoochteylingh admitted it was his wife who had originally hired the girl. In light of these revelations, the magistrates found in favor of Eechie Gerrets. ${ }^{44}$

From a different perspective, daughters hired out as maidservants also indicates the ubiquity of a gendered division of labor in early America. Using different methodologies, historians like Laurel Thatcher Ulrich, Ruth Swartz Cowen, and John Mack Faragher have provided details and analyses of gender-defined labor based on English cultural traditions in pre-industrial America ${ }^{45}$ Most Dutch women in early America were no less responsible for domestic labor than the women described by these authors. Hiring out daughters to work as maidservants eased the burdens of women in families that could afford to hire them, but deprived the mothers of their daughter's valuable labor at home. Unable to replace the lost labor of their daughters, who were often sent out at a young age, mothers in less affluent families experienced the full responsibility for domestic labor.

Life for most Dutch women in New Netherland and seventeenth-century New

${ }^{44}$ Kingston Papers, 1: 321-322.

${ }^{45}$ Ulrich, Good Wives; A Midwife's Tale: The Life of Martha Ballard, Based on Her Diary, 1785-1812 (New York, 1990); Ruth Swartz Cowen, More Work for Mother: The Ironies of Household Technology from the Open Hearth to the Microwave (New York, 1983); John Mack Faragher, Women and Men on the Overland Trail (New Haven, CT., 1979). 
York was a succession of interconnected activities and relationships defined by their sex and physically and psychologically connected to their roles as wives and mothers. ${ }^{46}$ On a voyage across the Atlantic on one of her own ships, merchant-trader Margaret Hardenbroeck Philipse ordered retrieval of a mop that had fallen overboard while being cleaned. According to religiously zealous fellow passenger and diarist, Jasper Dankaerts, turning the ship for such a trivial item was time-consuming and potentially dangerous for the sailors sent to the task. He attributed the incident to Hardenbroeck's “miserable covetousness." ${ }^{47}$ However, in reading Simon Schama's detailed cultural history of the seventeenth-century Dutch, Hardenbroeck's act may have been more complicated.

Schama maintained the seventeenth-century Dutch were sedulously clean in their environments to the point of an obsession, which he ascribed to a collective moral imperative. In that context, the cleaning brush was emblematic of what it meant to be Dutch in the United Provinces. Characteristic of the metaphoric expressions of patriotism using representations of cleanliness, was naval hero Admiral Maarten Tromp's attaching a broom to the bowsprit of his flagship. The message he conveyed was an intent to "sweep the English from the sea." Hardenbroeck's order to retrieve a

\footnotetext{
${ }^{46}$ Kathleen M. Brown, Good Wives, Nasty Wenches, and Anxious Patriarchs: Gender, Race, and Power in Colonial Virginia (Chapel Hill, 1996), 24-25; Ulrich, "The Ways of Her Household," Good Wives, chapter 1: 13-34; Julia Cherry Spruill,'Housewives and Their Helpers," Women's Life and Work in the Southern Colonies (Chapel Hill, 1938; rpt. New York and London, 1972), chapter 4: 64-84; Mary Beth Norton, Founding Mothers and Fathers: Gendered Power and the Forming of American Society (New York, 1996), passim.

${ }^{47}$ Dankaerts Journal, 53.
} 
lost mop was practical rather than metaphoric. However, the time and possible danger involved were out of proportion to the cost of the item, which may indicate its psychological significance rather than Hardenbroeck's parsimony. ${ }^{48}$

Schama maintained the tools of domesticity represented the cleanliness of home and hearth over the pollution of worldliness for the Dutch. Nevertheless, in the practical reality of pre-industrial America, these tools also expressed a mutually exclusive interdependent sexual division of labor between wives and husbands. To be sure, the division of labor was not always sharply defined, but wives generally accepted the lion's share of labor associated with home and hearth. ${ }^{49}$ Where many Dutch wives contrasted with most English wives was in their acceptance of responsibilities associated with the public sphere. ${ }^{50}$

Examples of the dichotomy of wives' private and public responsibilities are numerous, but often subtle. In 1668, Jeremias van Rensselaer wrote to Oloff van Cortlandt, his father-in-law, to request the dowry of Maria, his wife. He made the request on Maria's behalf so she could, "trade with it a little and order some goods ....

${ }^{48}$ Schama, "Housewives and Hussies: Homeliness and Worldliness," The Embarrassment of Riches, chapter 6, 375-480; the broom incident is recorded on 379.

${ }^{49}$ Particularly in dairy production, the division of labor was not necessarily distinctly defined. For New England see, Sarah McMahon, "Laying Food By: Gender, Dietary Decisions, and the Technology of Food Production in New England Households, 1750-1850," in Judith McGaw, ed. Early American Technology: Making and Doing Things from the Colonial Era to 1850 (Chapel Hill, 1994), 164-196: 166169.

${ }^{50}$ For wonderful examples of English women who went beyond domestic responsibilities see, Antonia Fraser, "With the War - Stronger Grown," The Weaker Vessel (New York, 1984), Part 2: 161-264. 
“In this correspondence van Rensselaer acknowledged his wife's desire and ability to contribute financially to the family and perhaps the patroonship, which was growing increasingly difficult to manage financially. However, Maria might have made the request herself. That she did not may have meant tacit deference to the intimate business relationship between her husband and her father. However, it is also possible Maria van Rensselaer was too busy. When the letter was written to her father, in June 1668, Maria was the mother of three young children, the youngest seven months. She also managed the patroonship's brewery. ${ }^{51}$

The status of the van Rensselaers was not typical for most families in New Netherland and seventeenth-century New York. Nevertheless, Jeremias van Rensselaer's expression of conjugal partnership within the context of patriarchy was common despite status. Another example of the phenomenon was expressed in the action against Annetie [Anna] Webber brought by Schepen [Magistrate] Jan Vinje. The reason for the suit was not revealed because Annetie's husband, Wolfert Webber, appeared in her place. Schepen Vinje refused to take action against the husband acting on his wife's behalf, maintaining, "the matter in dispute concerns only the woman ... that he is not bound to institute action against him, Webber." The Court of Burgomasters and Schepens ordered the appearance of Annetie, "but Webber may also appear as husband and guardian." Ignorance of the nature of the action against Annetie Webber prevents conclusions about the Court's refusal to allow her husband to act in her place, but Wolfert Webber's willingness to do so acknowledged his recognition of

${ }^{51}$ CJVR, 377, 393, 401; Christoph, "Worthy, Virtuous Juffrow,” 26. 
his marriage as a partnership. Further, the Court's reference to the husband as his wife's guardian shows he was officially recognized as the superior partner. ${ }^{52}$

Another subtle, but profound example of the dichotomy of women's domesticity is contained in the suit of a woman shopkeeper named in the record only as Mrs. Anthonie against Jan Harmensen, a cooper. Anthonie maintained a churn made by Harmensen was poorly constructed and therefore, "not merchantable." Unable to accept Mrs. Anthonie's opinion of his work, Harmensen offered to submit the churn to the judgment of two independent coopers..$^{53}$

Individually, the case is significant for what it indicates about Mrs. Anthonie. As a married woman living and conducting her business under English rule, for the case occurred in 1671, she expressed considerable independence in challenging the livelihood of an experienced craftsman. As a Dutch shopkeeper, however, her action was consistent with her cultural heritage and her sense of responsibility to her customers.

Equally important is what the churn represents. In making churns, barrels, and other containers, Jan Harmensen practiced a craft with a rich tradition and long history dating to ancient Egypt. He may have learned his craft under the careful tutelage of his father or perhaps a master cooper with whom he served an apprenticeship. Knowledge of wood and tools he may have acquired from his teacher, but experience gave him the skill to exploit their relationship. Yet, it is unlikely he would have known how to make

\footnotetext{
${ }^{52} R N A, 2: 81-82$

${ }^{53}$ Ibid., 6: 304.
} 
butter with the product of his labor sold to Mrs. Anthonie. Butter-making was also a specialized skill requiring initial supervision and practice to learn well and, therefore, was most often performed by someone experienced in domestic arts. While variables like occupation, location, and status influenced the amount of domestic labor done by wives, because butter was a staple of the colonial American diet and required considerable skill to make, it was often the responsibility of the matron of the house rather than children or servants. ${ }^{54}$

The existence of a churn made by a Dutch craftsman in seventeenth-century New York reinforces the gender-defined interdependent labor of wives and husbands in early America. In combination with artifacts and literary evidence from New England and the southern colonies, a churn mentioned in the records of seventeenth-century New York shows the cooperative labor of early American women and men was pervasive. ${ }^{55}$ As did New England wives, Dutch wives churned butter and performed other labors of domestic production for family and commercial use while their husbands

${ }^{54}$ Cowen, More Work for Mother, 29-30; for a brief description of dairying in the context of a farming family in early New York see, Fabend, A Dutch Family in the Middle Colonies, 82-83; for discussion of early American dairy production in colonial New England, chiefly Plymouth, from an archaeological perspective see, James Deetz, In Small Things Forgotten: The Archaeology of Early American Life (New York, 1977), 53-59; a very good description of the technology and skill required for butter-making in early America is, Joan M. Jensen, "Churns and Butter-Making Technology," Loosening the Bonds: Mid-Atlantic Farm Women, 1750-1850 (New Haven and London, 1986), chapter 6: 92-113.

${ }^{55}$ Deetz, In Small Thing Forgotten, 53-56; Spruill, Women's Life and Work in the Southern Colonies, 312; Ulrich, Good Wives, 22. 
cared for the animals that provided the raw materials processed by their wives. ${ }^{56}$ If the colonial family is viewed as a unit of production in which tasks were interdependent, the division of labor based on sex made sense for early Americans because it was efficient. However, it worked because early American women and men accepted the patriarchal model on which it was based.

England and Dutch women's acquiescence to their patriarchy defined roles as wives and mothers is further indicated by defamation suits. Specifically, in contrast with those of men, defamation suits involving women were more likely to consist of slanders of a sexual nature. Laura Gowing, for example, maintains that married, single, and widowed women's suits in ecclesiastical courts in seventeenth-century London were five times more likely to involve accusations of sexual slander than other causes. Using a methodology similar to Mary Beth Norton's for colonial Maryland, Kathleen M.

Brown maintains women and men in Virginia in the seventeenth century were far more likely to, "cast doubt upon reputations for sexual 'honesty'," when the targets of their invective were women. ${ }^{57}$

Similarly, cases involving women as victims in defamation suits among the

${ }^{56}$ Adriaen van der Donck, A Description of New Netherlands Thomas F. O'Donnell, ed., Jeremias Johnson, ed. (Syracuse, 1968), 41. Originally published in 1655 as Beschrijvinge van Nieuw Nederlandt.

${ }^{57}$ Laura Gowing, "Language, power and the law: women's slander litigation in early modern London," in Jenny Kermonde and Garthine Walker, eds. Women, Crime and the Courts in Early Modern England (Chapel Hill, 1994), 26-47: 26; Mary Beth Norton, "Gender and Defamation in Seventeenth-Century Maryland," WMQ, vol. 44, no. 3 (1987), 3-39; Brown, Good Wives, Nasty Wenches, and Anxious Patriarchs, 99100 . 
Dutch in America were usually over sexual gossip. When married women were slandered, the gossip was often adultery. Brown asserts one of the purposes of sexual gossip aimed at Virginia women was to create, "informal political networks in which women could wield influence over the behavior of their neighbors." In contrast, sexual slander against Dutch women and suits resulting therefrom were more likely to involve other family members and neighbors. ${ }^{58}$ The suit for damages for slander by Marretie Joris, wife of Nicolaas Boot, against Gabriel de Haes stemmed from a debt de Haes claimed Joris owed. When Joris denied the debt, de Haes replied, "whores and rogues act so." Joris called in two witnesses whom de Haes attempted to discredit by claiming they were servants of Joris. After the witnesses testified they were not Joris' servants, de Haes admitted the epithet against her and was fined six guilders to be paid to the deaconry of the city. However, the claim for restitution of Joris' honor and pecuniary recompense for the insult, which was common in such cases, were dismissed by the court. $^{59}$

Cases of slander against married women frequently brought their husbands into court to defend their wives' honors. In another case involving a disclaimed debt, Abraham Lucena sued Romain Servyn for a debt of 11 guilders, 16 stuivers and for slandering his wife as a whore when she pressed him for payment. Servyn maintained the amount of the debt was less than stated and, while denying the insult to Lucena's

\footnotetext{
${ }^{58}$ Dennis Sullivan, The Punishment of Crime in Colonial New York: The Dutch Experience in Albany During the Seventeenth-Century (New York, 1997), 112.

${ }^{59} R N A, 1: 328-329$; Restitution of honor was known as, "making amends," under Dutch law. See, Sullivan, The Punishment of Crime in Colonial New York, 111.
} 
wife, accused her of calling him a rogue. Abraham Lucena revealed, "he did not summon the deft. so much for the debt, as for the injury [to his wife's honor]." The case was continued for three sessions and in the final arbitration, in which Lucena's wife appeared as co-plaintiff, the court forced Servyn and Lucena's wife to affirm each other's virtue. Supporting Abraham Lucena's claim that the injury to his wife's honor was of greater importance, Servyn's outstanding debt was not prosecuted. ${ }^{60}$

As some authors have asserted, family and community were very important to the Dutch. ${ }^{61}$ Sexual slander cases emphasize the validity of that observation. In addition to husbands, other family members, neighbors, and friends participated in sexual slander litigation as plaintiffs, defendants, and witnesses. When Jan van Leyden [Iselsteyn] was accused by Anna Webber of making rude sexual comments, which included, “whore!, every man's whore!, and, I will have my pleasure of you, even though it be on the street before the pigs," he called as witnesses, "Abram Plancks wife, her two daughters, and two sister's daughters and the wife of Augustyn Heermans." ${ }^{92}$

${ }^{60} R N A, 3: 166,168,174$.

${ }^{61}$ Marshall, "The Core Family Unit and Lineage: Identity, Relations, and Realities," The Dutch Gentry, 1500-1650 (Westport, CT., 1987), chapter 1; Bertha Mook, The Dutch Family in the Seventeenth and Eighteenth Centuries: An ExplorativeDescriptive Study (Ottawa, 1977); for New Netherland see, Goodfriend, “"Too Great a Mixture of Nations': The Development of New York City Society in the Seventeenth Century," (Ph.D. dissertation, University of California, 1976); Fabend, A Dutch Family in the Middle Colonies; Donna Merwick, "Review of A Dutch Family in the Middle Colonies," Journal of American Ethnic History (Summer, 1995), 77-80; "Dutch Townsmen and Land Use: A Spatial Perspective on Seventeenth-Century Albany, New York,” WMQ, 37 (1980), 53-78: 68; Shattuck, “A Civil Society.”

${ }^{62} R N A, 1: 334-335$. 
Anna Webber was able to call in only one witness, Jannetie Hamel, who had been passing by Webber's house when the incident occurred. Hamel confirmed she heard van Leyden say, "Whore,” and, “The Gunner's Whore! For 12 English Shillings, thou hast served him; the cows hast, thou hast earned by adultery." In addition, Webber had marks on her face to affirm her claim Leyden had assaulted her physically as well as the testimony of another witness who claimed Leyden had physically assaulted him the same evening. ${ }^{63}$

The purpose of van Leyden's witnesses is unclear since their testimony was not recorded. Nevertheless, van Leyden may have used them to defend his character which was already known. In reaching its final decision in the case, the magistrates reflected, "the good inhabitants know of old, that the aforesaid Jan van Iselsteyn is a troublesome and quarrelsome person." He was fined, “one hundred Rix dollars [rijksdaelder]” and banished from the colony. ${ }^{64}$

Neither Wolfert Webber nor van Leyden had been strangers to slander litigation in which families had been involved. Six months earlier, in February 1655, in a suit over payment for the purchase of a sow, van Leyden counter-sued cooper Jan Harmensen because Harmensen's son had, "berated his wife for a whore and threatened to cut out her tongue.” In a separate suit, Wolfert Webber sought action against Judith and Sarah Verleth for, "striking him, in his own house and flinging stones at him." However, Judith Verleth testified they did so because Webber had, "berated her for a

\footnotetext{
${ }^{63}$ Ibid., 339.

${ }^{64}$ Ibid., 356; a rijksdaelder was 2 and $1 / 2$ guilders. Kingston Papers, 2: 763.
} 
whore and strumpet, and threatened in his own house to strike her with the whip." ${ }^{\circ 5}$

Further illustrating the importance of family in slander litigation was the suit of Anneken Felle against Lysbet Willems, who had called Felle a whore in the presence of Felle's father, Adriaan Vincent. Vincent and Felle's husband, Simon Felle, demanded redress. Anneken Felle was in court to interpret for her father, but was not named as a plaintiff. Willems was found guilty and was ordered to, "remain quiet for the future and to utter no more such infamous words, and keep herself still.",66

I believe two general conclusions are evident from the slander cases revealed in court records from Dutch courts in seventeenth-century America. First, regardless of literacy levels of Dutch-Americans in comparison to that of other European cultures in America, all shared limits imposed by the exigencies of pre-modern, pre-industrial life. In the seventeenth century informal verbal communication was often more important and faster than formal written correspondence. Many Dutch lived in communities with trade connections to other communities in America and Europe. In a colony founded on commerce in which trade was vital to the personal economic survival of many, a good reputation was essential. ${ }^{67}$

Second, however, sexual slander of women had more to do with the patriarchal

\footnotetext{
${ }^{65}$ Ibid., 290, 326.

${ }^{66}$ Ibid., 3: 55-56.

${ }^{67}$ Shattuck, "A Civil Society," 142.
} 
foundations of Dutch culture than economic security. ${ }^{68}$ Dutch wives were partners of their husbands within the context of marriage and motherhood. Sexual slander threatened women's roles as wives and mothers. Therefore, the slander indirectly negatively reflected upon the ability of men to control women. However, though their wives were open to verbal assault, Dutch husbands accepted and needed their wives' abilities and willingness to participate in the larger sphere of finances.

\section{Wives as Family Financial Managers}

While Dutch and English women shared common limits in the roles they were assigned in their respective cultures, the responsibility of wives for the economic welfare of their families in Dutch culture was greater. Specifically, Dutch wives were often required to manage the finances of their families. Importantly, however, married Dutch women appeared frequently in court over financial activities because they practiced family financial management as an element of domestic responsibility rather than an expression of independence.

An essential feature of wives' responsibility for family financial management among the Dutch in America was it developed from Dutch tradition rather than the

${ }^{68}$ Van Deursen, Plain Lives in a Golden Age, 81; "Jacob Cats and the married woman: a response to Agnes Sneller," 37; Laurence, "How free were English women," 131-132; Maria-Teresa Leuker, "Women's sphere and honour: the rhetorical realism of Bredero's farces," 68, Kloek, Women of the Golden Age; Schama, The Embarrassment of Riches, chapter 6. 
colonial American environment. ${ }^{69}$ Published accounts were left by English travelers in the Netherlands in the seventeenth century that indicate Dutch wives' roles for financial management was a curiosity for the English and more than a temporary fashion in the Netherlands. Commenting on his travels through the Netherlands in the early part of the seventeenth century, Fynes Moryson wrote, "the Woemen ... manage most part of the businesse at home ... they take all accompts. ${ }^{.70}$ More than fifty years later, in 1673, William Temple observed about the United Provinces, "women ... have the whole care and absolute management of all their Domestique." ${ }^{.71}$ Although hyperbolic, the comments of Moryson and Temple indicate need for further investigation and interpretations of Dutch women's roles as family financial managers.

While partnership was the theoretical foundation of Dutch marriages, some wives in New Netherland performed duties of financial management independently of their husbands. For some, like Maritie Tomas, it was a responsibility carried from marriage to marriage. Tomas was in her third marriage when her children from the earlier marriages demanded their inheritances. In order to comply, it was necessary for Tomas to give a detailed inventory of assets prior to her current marriage. She provided a list of property and monetary transactions that included,

${ }^{69}$ Van Deursen, Plain Lives in a Golden Age, 83; Schama, The Embarrassment of Riches, 403.

${ }^{70}$ Fynes Moryson, An Itinerary Containing His Ten Yeares Travell (Glasgow, 1907-1908), 58-59.

${ }^{71}$ William Temple, Observations Upon the United Provinces of the Netherlands, George Clark, ed. (Oxford, 1972), 89. 
"four iron hoops for a [hay] stack, a plough share and what else belongs to a plow, a cow and her first calf, two goats, 70 skepels of wheat, a hogshead of tobacco, delivered at 14 st[uivers] the pound, and cash paid for it and delivered, [and] half an aem of brandy." 72

Although Tomas' husband, Poulous van der Beeck, made use of the estate, he was neither present at the deposition nor assisted his wife in verifying the details. The document was signed by a notary, a witness, and significantly, Maritie Tomas made a mark rather than signed her name. ${ }^{73}$

Widowhood was not a prerequisite for women's knowledge and responsibility for family finances. Representative of the cases in which wives' responsibility for maintaining accounts is illustrated was the suit of Matewis Vos, acting as curator for the estate of Andries Johan Cristman [Kristman], against Poulous Heymans. On March 10, 1653, Vos sued Heymans for 28 florins, 10 stuivers, he claimed Heymans owed the Cristman estate. Heymans countered with the claim Cristman died owing him 38 florins, 10 stuivers. The justices ordered Heymans to prove his assertion at the next session of the court. ${ }^{74}$

At the following session, on March 24, 1653, Heymans brought suit against Vos for the difference in the claims, showing sworn proof. Vos, however, was not satisfied by the affidavit and demanded an oath to its accuracy. Heyman's wife, Tryntie Barents,

${ }^{72} \mathrm{~A}$ skepel was equivalent to approximately three-fourths a bushel while and aem or aam was equal to about forty gallons. Kingston Papers, 2: 765.

\footnotetext{
${ }^{73}$ Minutes of the Orphanmaster's Court, 2: 33-34.

${ }^{74} R N A, 1: 63$.
} 
subsequently appeared at the following week's session on March 31, 1653, and offered to make an oath declaring the accuracy of the account. Her offer was sufficient for the magistrates and they ruled in favor of Heymans. Vos was ordered to deduct the amount from what Barents, not her husband, owed to the Cristman estate. ${ }^{75}$

Neither sex nor ignorance were acceptable reasons for failing to meet financial obligations. On March 11, 1661, Metje Greveraat, a seamstress, was questioned by the Burgomaster's Court about why she had not paid her Rattle Watch and Burgherright taxes. ${ }^{76}$ She related she believed she should be excused from paying since, "she does not earn as much as a man." Showing little sympathy for her plight and reasoning, the court ordered the Rattle Watch fee paid while it temporarily suspended the Burgherright

\footnotetext{
${ }^{75}$ Ibid., 76-78. The record does not reveal all the information. Otherwise, the Cristman estate would have owed Heymans 10 florins. The conclusion is Tryntie Barents had an account with Cristman exclusive of her husband, but when a balancing of accounts was necessitated by Vos' suit the individual and family accounts were combined.

${ }^{76}$ Rattle-watch fees went for paying appointed individuals to patrol their communities through the night. Among other duties, those appointed in Beverwijck were required to, "sound the rattle every hour from 10:00 p.m. until 4:00 a.m. as they made their rounds." Sullivan, The Punishment of Crime in Colonial New York, 41; Burgherright, which was initiated to help stem the tide of illegal trade, allowed citizens of New Netherland to conduct business in the colony. Among the differences between the Great Burgherright and Small Burgherright in New Amsterdam, were the fees charged for each. The former was 50 guilders while the latter, which Metje Greveraat had not paid, was 20 guilders. E. B. O'Callaghan, Laws and Ordinances of New Netherland, 1638-1674 (Albany, 1868), 301-302; Dennis Maika, "Citizenship in Seventeenth-Century Manhattan: The Local Politics of Inclusion in the Changing World of Atlantic Commerce, 1657-1675," paper presented at the Fourth Annual Conference of the Omohundro Institute of Early American History and Culture, Worcester, MA., June, 1998, p. 10. Paper cited with permission.
} 
fee requirement. ${ }^{77}$

In a case related to the estate of Andries Johan Cristman, curator Vos sued Anneke Hendrick, who was represented by her husband, Jan van der Bil. Van der Bil was not sure if his wife had paid the debt of 24 florins, 18 stuivers and had no documentation to prove she had. In the presence of van der Bil's doubt and absence of records, the court ordered the amount paid. ${ }^{78}$

The concept of mutual responsibility for financial affairs as practiced by the Dutch was continued under English administration during the proprietorship of James, duke of York. In September 1666, William Teller petitioned the Court of Assizes to overturn an earlier ruling by the Albany court which had decided the case according to Dutch law. The Albany court had, "Ordered [Teller] to give in Particular of his Estate, as it was at the dec[ease] of his former wife, that her Childrens porcions might be ascertain'd and secured." Under English law a detailed accounting of the maternal estate was not required. Teller first argued through his attorneys that it was impossible to give the specifics owing to the lapse of time and his memory. To that he added a challenge to the basis on which the Albany court had arrived at its decision by revealing his, "ignorance of the [Dutch] Customes of Albany." In response to Teller's arguments, the defendants in the case, the executors of the estate of Cornelius Bogardus, Teller's wife's first husband, argued Teller was pretending ignorance in order to defraud his stepchildren of their inheritances. The Court of Assizes agreed and upheld the basis of

\footnotetext{
${ }^{77}$ Minutes of the Orphanmaster's Court, 2: 85; RNA, 4: 136.

${ }^{78}$ Ibid., 1: 63.
} 
the earlier ruling when it ordered Teller to give a detailed inventory of his late wife's estate. $^{79}$

Most Dutch wives accepted legal responsibility for financial affairs regardless of their level of education. Aafie Leender's husband, Jan Perier, was at sea when she petitioned the court for 700 florins owed to her husband from Captain Augustyn Beaulieu, whose assets had been attached by Capt. Roselyn [Rooselyn]. In spite of Roselyn's protestations and arguments to the contrary, Leenders successfully argued the money should be deposited with the court until her husband's return. That she did so successfully is remarkable considering she could neither read nor write. The court gave consideration to her illiteracy and her husband's absence in arriving at their decision. Sadly, however, Aafie Leender's husband was later ship-wrecked and never returned to New Netherland. The efforts of her creditors to collect on outstanding debts owed by Leenders and her husband eventually forced her into destitution. ${ }^{80}$

Consistent with the level of education of most women in the Netherlands and New Netherland and, therefore, appearing in the records more often, were wives who could read but not write. In spite of their limited education, they were competent managers of family assets and liabilities. The woman with whom this chapter began,

\footnotetext{
${ }^{79}$ Peter R. Christoph and Florence A. Christoph, eds. New York Historical Manuscripts, English: Records of the Court of Assizes for the Colony of New York, 1665-1682 (Baltimore, 1983), 29-30 [hereafter cited as Records of the Court of Assizes]; Under English law husbands had control of their wives' property until death. Narrett, "Dutch Customs of Inheritance," 31-40; Marylynn Salmon, Women and the Law of Property, 183. For the legal requirements for making inventory of deceased parents' property see, R.W. Lee, An Introduction to Roman-Dutch Law (Oxford, 1931), 93-96.

${ }^{80} R N A$, 3: passim.
} 
Maritie Jans Joncke, was very specific about the people and amounts, including monetary and barter transactions, owed to her and for which she was indebted. Yet, she made a mark rather than signed her name to the inventory and will. ${ }^{81}$ Neither she nor her late husband, Cornelius van Langevelde, kept an account book. In affirming the accuracy of the information given the notary, Maritie testified, "on her woman's troth and according to the best of her knowledge." 82

While many women in New Netherland did not or were unable to maintain written accounts, the books of those who did were an important source of legal evidence. Seletje Arens' frequent appearances in court were the result of arguments and counter-arguments in her efforts to assert a claim against Teunis Tomazen Quick for 92 guilders and 8 pennings. ${ }^{83}$ Arens consistently presented her account book to enforce her claim. In one session, Arens' son was called in to verify Quick had, in his presence, signed his mother's book for the debt in question. Quick continued his efforts to avoid payment, which given the persistence of Arens, only delayed the inevitable. The case was finally decided in her favor when the magistrates of the Court of Burgomasters and Schepens, acting as arbiters, used her account book to determine the amount owed by Quick. $^{84}$

${ }^{81}$ See the possibility of exceptions to using marks rather than signatures, fn24.

${ }^{82}$ Minutes of the Orphanmaster's Court, 2: 35-36.

${ }^{83} \mathrm{~A}$ penning was equal to one-sixteenth a stuiver and a stuiver was equal to onetwentieth of a guilder. Kingston Papers, 2: 763.

${ }^{84} R N A$, 4: 298-329: passim. 
However, existence of an account book sometimes worked to a wife's disadvantage, as in the case of the wife of Viela Roy. ${ }^{85}$ Anthony Casko built a cellar for the Roy family and on June 5, 1683, he sued Mrs. Roy in the Court of Albany for his wages. The account book of the defendant was entered as evidence and Casko used it to successfully prove his claim. ${ }^{86}$ Mrs. Roy's account book is also evidence Dutch women continued maintenance of family accounts after the English assumed political authority in the colony.

Financial management by literate wives was not confined to keeping account books. In October 1663, to collect an outstanding debt on a house she and her husband owned, Anneken (Annetie, Anneke) van Borssum, the wife of Eghbert Borssum, produced a deed. The house had been sold to Albert van Heemst who subsequently sold it to Pieter Lucasen, apparently without informing him of the outstanding debt. Lucasen challenged the van Borssum's claim to ownership and the outstanding debt, which resulted in their suit against him. It is not clear if Eghbert van Borssum was present at the proceeding. Nevertheless, Anneken van Borssum's production of the original mortgage to the property was sufficient for the court to rule in the couple's favor. ${ }^{87}$ In another example, in March 1664, Eghbert Meindersen sought release from a contract to purchase land from Arien Huybersen owing to Huybersen's inability to produce a deed.

${ }^{85}$ Her name was not recorded.

${ }^{86}$ Van Laer, trans. and ed., Minutes of the Court of Albany, Rensselaerwyck, and Schenectady, 1680-1685, 3 vols. (Albany, 1926-1932), 3: 351.

${ }^{87} R N A, 4: 321-322$. 
Representing the interests of her family, Huybersen's wife produced the deed and explained the delay was the result of her inability to procure the services of the surveyor. Regardless, the court ruled in Meindersen's favor. ${ }^{88}$

While available records indicate many wives were competent financial managers, most performed that responsibility in concert with their husbands. In that regard, marriage was the partnership individuals like Jeremias van Rensselaer professed ${ }^{89}$ There are many expressions of conjugal partnership in administering family finances in the court records of New Netherland and seventeenth-century New York, but none more cogent than those presented by the previously named Anneken and Eghbert van Borssum. They appear many times over a thirteen year period in the Records of New Amsterdam, diligently protecting and promoting the financial interests of their marital partnership. In one instance, Eghbert was named as defendant in a suit brought by mason Roeloff Jansen, who claimed van Borssum owed him wages for unspecified contracted work. While not named a defendant, Anneken van Borssum appeared with her husband to challenge Jansen's claim of completion of the work according to the contract. They mutually agreed to pay Jansen when the work was complete. ${ }^{90}$

In another instance, the van Borssums filed suit against Frans Janzen van Hooghten for wages earned by their sons, Barent and Hendrick. The boys had been

\footnotetext{
${ }^{88}$ Ibid., 5: 40.

${ }^{89}$ CJVR, 297, 300.

${ }^{90} R N A, 2: 20$.
} 
contracted by their parents to work for van Hooghten, who maintained that due to lost time their term of service was not over. The suit was initiated by Eghbert van Borssum on November 1, 1664, but van Hooghten was in default. At the following week's session, at which van Hooghten was present and in van Hooghten's counter-suit the following month, Anneken represented the interests of her family. Another eighteen months passed before the case was finally settled in the van Borssum's favor. Eghbert represented the family at the final hearing. ${ }^{91}$

The activities of Anneken van Borssum illustrate the essential role played by wives within their marriages for financial affairs, but there is also evidence husbands reciprocated. In January 1657, when Sarah Pietersen was too sick to come to court as plaintiff in a suit against Dirck de Noorman for a debt of 12 guilders, 16 stuivers, her husband, Willem Koeck, appeared for her. He produced an account book, ostensibly maintained by his wife, in which the debt was recorded. ${ }^{92}$

In another example, this one touching on domesticity, Hendrick Willemsen sued Jan Cornelissen van Horne over a muff that his wife gave to Van Horne for alteration. Willemssen claimed the muff was ruined by Van Horne and demanded payment or return of the muff. ${ }^{93}$ Van Horne denied the muff was ruined, maintaining it was taken in

${ }^{91}$ Ibid., 5: 150, 153, 171; 6: 12.

${ }^{92}$ Ibid., 2: 257. Presumably, the suit was settled out of court. De Noorman claimed an off-setting amount owed by Pietersen and the suit was turned over to arbiters for reconciliation. Reconciliation by arbiters was a common practice under Dutch jurisprudence. condition.

${ }^{93}$ Willemsen was apparently demanding the muff be restored to its original 
rather than cut off. The court ordered the matter turned over to arbiters to decide. ${ }^{94}$

Wives conducting duties as family financial managers and husbands and wives acting in concert or representing each other in financial affairs illustrates several important features of Dutch culture in early America. First, wives' responsibility for maintaining accounts was not only acceptable, but an essential function within some families. Husbands like Poulous Heymans and Eghbert van Borssum were dependent upon their wives' knowledge and abilities for maintenance of family and business accounts.

Second, court appearances that reveal cooperative conduct between wives and husbands in financial management shows the application of partnership in early American Dutch marriages. Some authors express Dutch wives' knowledge and conduct in handling financial affairs in ways similar to that of Laurel Thatcher Ulrich's deputy-husbands; i.e., as adjuncts to their husbands. ${ }^{95}$ However, Dutch wives were often more than surrogates attending to affairs in which their husbands were the primary participants. Many individual wives and husbands assumed primary responsibilities for financial and other nondomestic activities as needed.

Third, wives performed nondomestic responsibilities within the context of patriarchy. Maritie Jans Joncke was a good steward of her family's assets in her roles as a wife and mother. The level of family stewardship by some wives, like Mrs. Anthonie

${ }^{94} R N A, 3: 33$.

${ }^{95}$ Ulrich, "Deputy-Husbands," Good Wives, chapter 2; Kammen, Colonial New York, 91-94; Shattuck, “A Civil Society,” 165. 
who challenged cooper Jan Harmensen about a churn and Maritie Tomas who managed her assets from widowhood into remarriage, is difficult to discern. However, as the activities of Maria van Rensselaer, who was a mother, brewer, trader, and wife and Anneken van Borssum, who defended remuneration for her son's labor, show; the nondomestic activities of many married women were integral to their roles as wives and mothers. In addition, as defamation suits reveal, women were more likely than men to have their moral integrity impugned, which further reflects on their roles as wives and mothers. ${ }^{96}$

Dutch culture in Europe and America was patriarchal, but in ways significantly different for women than patriarchy in England and the rest of seventeenth-century America. Marriage and family were too important in Dutch culture for most women to consider a life of independence from men. Nevertheless, their roles as wives entailed and even required them at times to act with autonomy in pursuit of financial and other goals associated with their families. Many young women received formal education and training that prepared them for domestic and nondomestic responsibilities in marriage. Owing to that, wives and husbands were mutually reliant to manage the public affairs of their families and represent their family's interests in public forums like court. There are no records from New Netherland and seventeenth-century New York that show Dutch wives were more satisfied with their roles than other women in early America. Nevertheless, with their knowledge and willing assistance, women were integral to the success of their families and therefore to colonial Dutch society.

\footnotetext{
${ }^{96}$ Sullivan, The Punishment of Crime in Colonial New York, 113.
} 
Chapter Two

Dysfunctional Marriages and the Transition from Dutch to English Law 
"If there was a church for unmarrying as well as marrying, I would go there right away, and I believe I should get followers.

Who, in order to be the first ones there, would walk so hard they would gasp for breath."

On Monday February 18, 1658, New Netherland merchant-trader, Nicolaas

Boot, filed a formal complaint against his wife, Merritje Joris, in the Court of

Burgomasters and Schepens of New Amsterdam. Expressing regret that action by the

Court was necessary to resolve his differences with her, he called on the magistrates to, "reprimand her for her irregular life, and if she will not amend, that they separate one from the other." Among his complaints about her, Boot charged Joris with, "drinking in all the groggeries and holes [taverns], and being so drunk he cannot keep house with her."2

Rather than waiting to hear Joris' testimony on the next court day, which would have been common, the magistrates ordered her appearance immediately. When she was asked about the behaviors reported by Boot, Joris expressed a level of dissatisfaction with her marriage comparable to her husband's. She neither denied Boot's assertions nor affected contrition for her behavior. Instead, she revealed contempt for her husband and asserted social equality based on financial independence. She maintained, "she drinks her own and not his substance ... that he himself goes

${ }^{1} \mathrm{~J}$. van Volten, Het Nederlansche Kluchspel van de 14e tot 18e eeuw, 3 vols. (Haarlem, n.d.), 2: 292, in van Deursen, Plain Lives in a Golden Age, 92.

${ }^{2} R N A, 2: 335$. 
drinking, rollicking and full." 3 Furthermore, when the court ordered her to live in peace with her husband in spite of her expressed intent not to do so, she challenged the magistrates' decision by offering an additional expression of independence; maintaining she and Boot,

"always had wine and beer in the house, and that he had not put either wine or beer in the house for her, which is the reason she goes now and again for half a Mutje and a couple of pots of beer and he does not pay the cost."

However, Joris did not only rely on expressions of gender-based equality and financial independence. She also maintained her husband, "frequently beat her and diverse times shut her out." ${ }^{5}$ Denied by Boot, the accusation was enough to lead to his arrest by the Schout. ${ }^{6}$ Had Boot been prosecuted and found guilty, he may have experienced imprisonment and, in this circumstance, "such punishment as the Magistrates shall judge proper as an example to others."

${ }^{3}$ Ibid.

${ }^{4}$ Ibid. A mutjie [mutje, mutsje] was equal to 15 fluid ounces, English measure. Kingston Papers, 2: 765n1.

${ }^{5} R N A, 2: 335$.

${ }^{6}$ A Schout was a combination sheriff and public prosecutor. Stefan Bielinski, "The Shout in Rensselaerswijck: A Conflict of Interests," in Nancy Anne McClure Zeller, ed. A Beautiful and Fruitful Place: Selected Rensselaerswijck Seminar Papers (Albany, 1991), 3-12: 3.

${ }^{7}$ Hugo Grotius, Jurisprudence of Holland, R.W. Lee, trans. (Oxford, 1926), 29. The quote is from $R N A, 2: 338$. 
this chapter, Boot was not tried for spousal abuse in this circumstance or after a later similar accusation of abuse made by Joris. ${ }^{8}$

Records of marital litigation like the one between Boot and Joris are symptomatic of conflicts some Dutch couples experienced as a consequence of their cultural heritage. Seventeenth-century Dutch culture in Europe and America conferred responsibilities on wives that were uncommon for women in the rest of Europe and America. Yet, Dutch culture had patriarchal models that limited social and legal opportunities for women that were similar to those of other countries. While it is impossible to determine if Merritje Joris' alledged excessive consumption of alcohol was a cause or consequence of her unhappy marriage, her expressions of financial independence from her husband were consistent with her responsibilities and those of many other Dutch wives in New Netherland and seventeenth-century New York. Moreover, Joris' inference that her husband's behavior, "drinking, rollicking and full," made her own similar behavior acceptable, particularly since he would not provide wine and beer for her, implies frustration over the limits of socially defined gender roles. Boot's indignation about his wife's behavior was consistent with social expectations of decorum for married women. Joris' assertion of Boot's failure to supply her with wine and beer also addressed social mores by implying he failed as a provider. The couple's differences were never completely resolved. They finally achieved a legal separation from bed and board because their frustrations at each other's behavior proved enduring

\footnotetext{
${ }^{8}$ Ibid., 4: 304.
} 
enough to overcome religious, social, and legal impediments to dissolution. ${ }^{9}$

Divorce and separation initiated by either spouse were possible under Dutch law.

And, Dutch wives exercised responsibilities and expressed independence uncommon for married English women living in Europe and America. ${ }^{10}$ Notwithstanding, few spouses sought litigation against their partners with the intent of dissolving their marriages.

While marital dissolutions were possible under Dutch civil law, interrelated religious and social factors affected opinions about the permanence of marriage and influenced

${ }^{9}$ The terms divorce, separation, and less frequently, annulment were used interchangeably in the records of marital litigation in New Netherland, but each had specific requirements and consequences under Dutch law and the legal systems of other Western European countries. One of the most important consequences was the option of remarriage to a third party, which divorce and annulment conferred but separation from bed and board did not. Roderick Philips, Putting asunder: a history of divorce in Western Society (Cambridge, 1988), 3-5; Lee, Introduction to Roman-Dutch Law, 8892; Simon van Leeuwen, Commentaries on Roman-Dutch Law, C.W. Decker, ed. J.G. Kotze, trans. 2 vols. (London, 1921), 1: 120, [hereafter cited as Commentaries]. Van Leeuwen's Commentaries was originally published in Dutch in 1664 under the title, Het Roomsch Hollandsche Recht. Some scholars consider van Leeuwen's work secondary only to Grotius', De Inleiding tot do Hollancsche Rechtgelerheid [Introduction to the Jurisprudence of Holland], originally published in 1631. Sullivan, The Punishment of Crime in Colonial New York, 286n1.

${ }^{10}$ Much of this difference was prescriptive rather than actual, except at common law and particularly wive's control of property. Antonia Fraser, The Weaker Vessel, challenged the validity of separate spheres for women and men by discussing the realities of life for seventeenth-century English women. See also, Shoemaker, Gender in English Society, 1650-1850. For assertions of practical expressions of women's legal disabilities in early American English culture see, Norton, Founding Mothers and Fathers; and, Brown, Good Wives, Nasty Wenches, and Anxious Patriarchs. The realities of women's experience asserted by authors like Norton and Brown are challenged in several works including, Ulrich, Good Wives; Cowen, More Work for Mother; McMahon, "Gender, Dietary Decisions, and the Technology of Food Preservation"; Faragher, "The Midwestern Farm Family, 1850," Women and Men on the Overland Trail, chapter 2, reprinted in, Kerber and De Hart, eds. Women's America, 117-129. 
laws that militated against dissolutions. Therefore, dissolutions were rare in Dutch society, but did occur when spouses persisted in their efforts to obtain them.

An array of personal and social conditions likely shaped the decisions of Dutch wives and husbands to stay in dysfunctional marriages. Another possibility was the reluctance of Dutch magistrates to grant dissolutions. Dutch magistrates were limited by civil laws with religious foundations. Clerics in the Dutch Reformed Church and other Protestant denominations in the United Provinces accepted civil divorce in extreme circumstances, but there were no provisions for ecclesiastical dissolutions. Consequently, irreconcilable couples were sometimes referred to civil authorities by reluctant clerics. ${ }^{11}$ The official position of insolubility of marriage by the Dutch Reformed Church and other Protestant sects influenced the formation of civil laws governing marriage that helped to form the foundation upon which judicial decisions in dissolution cases rested. Consequently, even in cases in which civil grounds for permanent dissolutions were met, Dutch magistrates rarely granted them unconditionally. Dissolutions usually occurred only after repeated attempts by court officers to effect reconciliations between disputing couples. With little regard for victims of abuse, magistrates often assiduously insisted on reconciliations in the face of repeated instances of abuse and admonitions to offending husbands to reform their abusive behaviors.

\footnotetext{
${ }^{11}$ Manon van der Heijden, "Secular and Ecclesiastical Marriage Control: Rotterdam, 1550-1700," in Anton Schuurman and Pieter Spierenburg, eds. Private Domain, Public Inquiry: Families and Life-Styles in the Netherlands and Europe, 1550 to the Present (Hilversum, 1996), 39-60: 57; Van Deursen, Plain Lives in a Golden Age, 92.
} 
If marital dissolution was difficult in Dutch courts, it was extremely rare among the English. Specifically, English law made no provision for civil dissolution of marriage. Marital litigation was the prerogative of the Anglican Church, which through ecclesiastical courts, rarely granted marital dissolutions for any reason. ${ }^{12}$ As a result, some historians have characterized early modern England as a divorceless society. ${ }^{13}$ While it has been argued recently that dissolutions occurred in England among all strata of society in spite of ecclesiastical prerogative, complexity of prerequisites and questions of legality forced many desiring dissolutions to choose extra-legal means like desertions, wife-sales, and private separations. ${ }^{14}$

In spite of the legal complexities of marital dissolution under English law, during the proprietary period [1664-1673, 1674-1685], at least two of New York's governors, Lovelace and Andros, granted marital dissolutions. They granted them without regard to nationality to a handful of Dutch and English couples. In 1955, New

\footnotetext{
${ }^{12}$ While rare, ecclesiastical courts in England sometimes granted dissolutions for adultery, incest, bigamy, and more rarely, cruelty. Lawrence Stone, Road to Divorce: England, 1530-1987 (Oxford and New York, 1990), 24, 141-230.

${ }^{13}$ Lawrence M. Friedman, A History of American Law (New York, 1985), 203; Peter Charles Hoffer, Law and People in Colonial America (Baltimore and London, 1992), 76-77; Matteo Spalletta, "Divorce in Colonial New York," New York Historical Society Quarterly, vol. 39, no. 4 (Oct., 1955), 422-440: 427; Stone, The Family, Sex, and Marriage, 34; Nancy F. Cott, "Divorce and the Changing Status of Women in Eighteenth-Century Massachusetts," WMQ, vol. 33 (Oct., 1976), 586-614: 588-589. In England, the Marriage Act of 1653 made marriage a civil act that required a ceremony before a justice of the peace but did not provide for dissolution of marriage. The act expired with the Restoration. Philipse, Putting asunder, 130-131.

${ }^{14}$ Stone, Road to Divorce, 141-230; Stone, Broken Lives: Separation and Divorce in England, 1660-1857 (New York, 1993), passim.
} 
York legal scholar, Matteo Spalletta found the dissolutions granted by Lovelace and Andros untenable on the presumption they used dissolutions granted earlier under Dutch authority as a common law precedent. ${ }^{15}$ There is evidence the New York governors considered marital litigation cases administered by Dutch authorities, but several mitigating factors not mentioned by Spalletta were present in proprietary New York that may have also been considered. Regardless of why they were granted in apparent violation of English law, separations and divorces granted by English governors did not occur without careful contemplation of specific circumstances in each case and several failed attempts to reconcile litigious couples. While jurisprudence in marital litigation cases differed for the Dutch and English in Europe and America, both cultures emphasized preservation of marriage even when law and circumstances permitted dissolutions. ${ }^{16}$

In spite of the Protestant Reformation, insolubility persisted as a legal and social characteristic of marriage formation in England and the United Provinces. In England and other Protestant countries, few areas of ecclesiastical law gave Protestant reformers and civil authorities more difficulty than settling the question of marital dissolution. Accustomed as many in the twenty-first century West are to the ubiquity of divorce, Reformation opinions upon which laws governing marriage were based are archaic or at least seem little changed from those that formed the foundation of Catholic Canon law.

${ }^{15}$ Spallatta, "Divorce in Colonial New York," 434-435.

${ }^{16}$ Owing to Puritan settlement and the recognition of marriage as a civil union, New England permitted marital dissolutions. Cott, "Divorce and the Changing Status of Women," 589. 
Part of the reason for that was Protestant reformers who favored greater availability of dissolutions based their opinions on reinterpretations of biblical passages used by the clerics in the Catholic Church to argue against dissolutions. The reformers did not offer innovative approaches to new circumstances. ${ }^{17}$ Therefore, it is not surprising the evolution of marital dissolution varied between countries and cultures in Protestant Europe.

More difficult than interpreting influences on laws governing marital dissolution in Reformation Europe is determining the causes of marital strife among the Dutch in America. The absence of letters and diaries of discontented couples in America results in uncommon reliance on court documents that are inadequate for drawing definitive conclusions. Unlike Nancy F. Cott, who was able to discern causes of marital discord from seventeenth and eighteenth-century Massachusetts court records, the records from New Netherland and seventeenth-century New York are more circumspect about marital litigation. ${ }^{18}$ Owing to the length of time covered by her studies, i.e., 100 years, and the frequency of marital litigation in Massachusetts, Cott enjoyed use of a large number of cases in comparison to New Netherland and seventeenth-century New York. In addition, the system of court recording in eighteenth-century Massachusetts was more

\footnotetext{
${ }^{17}$ Phillips, Putting asunder, 1, 40-94.
}

${ }^{18}$ Cott., "Divorce and the Changing Status of Women"; Eighteenth-Century Family and Social Life Revealed in Massachusetts Court Records," Journal of Social History, 10 (1979), 20-42. Contrary to Massachusetts, New Netherland records rarely reveal the testimony of witnesses in marital litigation cases. 
detailed than in New Netherland and seventeenth-century New York. ${ }^{19}$ Court records from New Netherland and seventeenth-century New York often reflect the final stages of marital dysfunction. They rarely show the processes individuals and couples followed in arriving at decisions to seek legal intervention in their differences. Specifically, the dynamics of dysfunction are often difficult to distinguish and therefore result in confusion over whether specific behaviors were the cause of marital strife or the result of it.

As a consequence, the majority of records of marital litigation from New Netherland and seventeenth-century New York reveal behaviors consistent with those indicated in the records of marital dysfunction in Europe and in New England and the Chesapeake in the seventeenth and eighteenth centuries. ${ }^{20}$ However, among the Dutch, social and legal reluctance to accept marital dissolution within an ostensibly flexible patriarchal social structure produced distinguishable conflicts for some wives. Dutch couples lived in a culture that valued nondomestic contributions and required uncommon responsibilities of wives, but limited their opportunities owing to their sex. Dutch court records indicate wives acted independently and in concert with their husbands in promoting the interests of their families more often than did wives in English culture in Europe and America. Consequently, some Dutch wives developed a

${ }^{19}$ Cott, "Divorce and the Changing Status of Women," 387-388.

${ }^{20}$ Stone, Road to Divorce, passim; Phillips, Putting asunder, passim; Spruill, "Conjugal Felicity and Domestic Discord," Women's Life and Work in the Southern Colonies, chapter 8: 163-184; Brown, Good Wives, Nasty Wenches, and Anxious Patriarchs, 336-342; Ulrich, Good Wives, 110-113. 
self-reliance that caused them to rebel against husbands who behaved in ways that conflicted with distinctly Dutch perceptions of marriage as a partnership of shared opportunities and responsibilities.

While dissolution of marriage was difficult for Dutch and English couples in Europe and America in the early modern period, creation of marriages was complicated by social and religious trends that conflicted with pre-Reformation traditions. Protestant reformers who influenced the religious cultures of England and the United Provinces of the Netherlands retained vestiges of the Catholic Church's definition of marriage and edicts governing marriage derived therefrom. The Catholic background was expressed in various ways in the laws that prescribed the steps necessary for creating legal marital unions within each country. ${ }^{21}$ One reason for similarities between Catholic and Protestant positions on marriage was acceptance of the biblical imperative that marriage established a permanent temporal bond.

Without minimizing significant differences between Catholic and Protestant theological positions on marriage, it is not surprising that Protestant countries devised laws governing marriage similar to those based on Catholic doctrine. Like the rules governing Catholic marriages, Protestant reformers based their opinions about marriage on biblical interpretations. For example, Luther and Calvin used logic to reinterpret biblical passages upon which the Catholic doctrine of marriage as a sacramental union

\footnotetext{
${ }^{21}$ Phillips, Putting asunder, 15-30; Stone, "The Law and Custom of Marriage," Road to Divorce, chapter 2: 52-66.
} 
was based. ${ }^{22}$ Marital dissolution was so repugnant to Martin Luther, he once suggested than rather than dissolution, wives married to impotent husbands should consider conceiving a child through union with another man, perhaps her husband's brother. He suggested keeping such unions secret and ascribing the offspring to her husband. ${ }^{23}$

Religious prescriptions about the permanence of marriage affected social constructs in marriage formations. There is disagreement about when affective unions began to replace contracted marriages in significant numbers in northern Europe and America. For England, Lawrence Stone maintained the eighteenth-century was an important period of transition in the rise of affective marital unions, but recognized the beginning of the process in a much earlier period. Nancy F. Cott recognized a similar rising patterns of affective unions in the latter half of eighteenth-century Massachusetts. $^{24}$

Historians of Dutch history maintain one consequence of the Reformation in the Netherlands and Erasmian humanism was an increase in affective unions. ${ }^{25}$ Manon van der Heijden maintains that, "marital love became the most important object of

${ }^{22}$ Phillips, Putting asunder, 27, 43.

${ }^{23}$ Ibid., 42-43.

${ }^{24}$ Stone, "The Companionate Marriage," The Family, Sex, and Marriage, chapter 8: 217-253; Cott, "Eighteenth-Century Family and Social Life," 32.

${ }^{25}$ Van Deursen, Plain Lives in a Golden Age, 84-95; Schama, The Embarrassment of Riches, 421; Van der Heijden, "Secular and Ecclesiastical Marriage Control," 42. 
marriage."26 Inasmuch as writers like van der Heijden focused on a specific place, the argument about when affective unions began to supplant arranged marriages comes down to absolute numbers, which is very difficult if not impossible to determine. Further, as Schama and van Deursen indicate, status was an important factor in whether arrangement of marriage followed through family connections or independent action. ${ }^{27}$

Another factor that influenced how marriage formations took place was endogamy. While age of majority and the requirement for parental consent were redefined after the Reformation, independent decisions to marry based on affective attraction were militated by the limits of early modern social environments and levels of technology. Specifically, most people married within their family's social and economic position and, given the difficulties and hazards of travel, seldom went too far afield to live or search for a mate. In combination with the force of the convention of parental involvement in marriage formations and the perception that marriage created an irrevocable bond, these factors resisted independent action in choosing marriage partners. $^{28}$

However, emigration to America complicated the role of Dutch parents in influencing the choice of mates for their children. One example was the marriage of Jeremias van Rensselaer and Maria van Cortlandt. Wealth and social status, which was

${ }^{26}$ Ibid.

${ }^{27}$ Van Deursen, Plain Lives in a Golden Age, 85; Schama, The Embarrassment of Riches, 421.

${ }^{28}$ Christoph, "Social and Religious Tensions in Leisler's New York," de Halve Maen, vol. 67, no. 4 (Winter, 1994), 87-92: 88-89. 
considerable for the van Rensselaer family, may have been important considerations in choosing spouses for children in both families. Jeremias van Rensselaer and, for that matter, Maria's father, Oloff Stevensen van Cortlandt, might have used family or business connections to arrange a match with someone in the United Provinces. Depending on details, an arrangement like that would have required time consuming and potentially hazardous Atlantic crossings by one or both the affianced. However, why go to those lengths if not necessary? Maria van Cortlandt came from a family with a financial standing similar to the van Rensselaers and she possessed qualities important to someone with Jeremias van Rensselaer's responsibilities. ${ }^{29}$

While the records do not indicate the level of involvement by Maria's family in the marriage arrangements, Jeremias went forward without consulting his family. ${ }^{30} \mathrm{He}$ was justifiably apprehensive when informing his mother, Anna van Rensselaer, after the fact. Before corresponding directly with her after his marriage, van Rensselaer wrote to his brother, Jan Baptist, who was in the Netherlands at the time. He requested Jan Baptist to inform their mother of his marriage. He wrote, "After giving my greetings to

\footnotetext{
${ }^{29}$ While the van Rensselaer and van Cortlandt families were not of the same social standing, owing in part to the van Rensselaer's longer standing wealth and financial diversity, the two families had mutual business dealings. For example, see the letter, "Oloff Stevensen van Cortlandt to Jeremias van Rensselaer, June 19, 1657," CJVR, 50-51, in which van Cortlandt acknowledged receipt of a letter concerning trade items from Anna van Rensselaer, Jeremias' mother.

${ }^{30}$ Since Maria was a minor, permission from Oloff Stevensen van Cortlandt was legally required. She and van Rensselaer were married on July 12, 1662, eight days prior to Maria's seventeenth birthday. Van Laer,'Introduction," CJVR, 3; Christoph, "Worthy, Virtuous Juffrow," 25-26, maintains Maria was seventeen or almost seventeen depending on the family record or church record of her birth.
} 
mother you will please tell her also that I have married Maria van Cortlandt and tell her that if we had not been so far from each other I should not have ventured to do so without her knowledge." ${ }^{31}$ Anticipating Anna's reaction and concerns when she heard the news from Jan Baptist, Jeremias supplied him with the most potent argument to use with their mother by implying holy sanction to the union. He indicated God had brought Maria to him and assured Jan Baptist, they would rely on God for "peace and health," in their marriage. ${ }^{32}$

Anna van Rensselaer was apparently close to her son, Jeremias, and the news of his marriage must have been something of a shock to her. Information in a letter she wrote to him soon after his arrival in New Netherland in 1656 to assume the duties of director of Rensselaerswijck illustrate. In the letter, Anna van Rensselaer expressed concern her son might be led astray without parental supervision in what she believed was an uncivilized environment. She admonished him to "shun the company of light [i.e., loose] women of whom New Netherland is full."33 And, she rarely ignored opportunities in her letters to him to mention concern about the state of his soul. When he delayed in joining the Dutch Reformed Church after his arrival in New Netherland, she reflected he had failed to do so,

"because you wish to have a freer rein and to indulge in greater dissipation in this corrupt world, which grieves me exceedingly. It is

\footnotetext{
${ }^{31}$ CJVR, 296-297.

${ }^{32}$ Ibid.; Sullivan, Punishment of Crime in Colonial New York, 132.

${ }^{33}$ CJVR, 131.
} 
namely, plainly written that God can be found only by those who seek Him and that one must first of all seek the kingdom of God and His justice and that then all things will be bestowed upon us." 34

No greater indication of Jeremias' apprehension about personally informing his mother of his marriage exists than his delay in writing directly to her about it. ${ }^{35} \mathrm{He}$ wrote to Jan Baptist the day after his wedding to Maria, on July 13, 1662, but did not write to Anna until the August 19 of that year.

In his August 19 letter to Anna, Jeremias tried to anticipate and alleviate her concerns that his marriage was made in haste. In contrast to what he wrote to Jan Baptist that time and distance had prevented informing the family, he related to his mother he, "had been thinking of her [Maria] already for a year or two before when now and then I did an errand at the Manhattans," traveling from the Rensselaerswijck patroonship. As with Jan Baptist, he then invoked holy sanction of the union by defending his new wife's moral character, reflecting, "for to live in peace together so calmly and peacefully with a wife who has always led a good life and feared the Lord God is the best thing I could wish for here on earth." ${ }^{, 36}$

${ }^{34}$ Ibid. Jeremias joined the church soon after receipt of this letter from his mother. Anna van Rensselaer wrote the letter in February 1659 and Jeremias related to her in a letter dated June 1660 he had joined the church the previous year.

${ }^{35}$ Jeremias and Anna sometimes went for long periods of time without writing to each other. However, it is clear from the context of his letters he was concerned about her silence regarding his marriage. Thirteen months after he initially informed Anna of his marriage, he announced the birth of her grandson, Kiliaen, but also admonished her for not writing since the announcement of his marriage. Ibid., 328.

${ }^{36}$ Ibid., 300-301. 
Jeremias' anxiety about his mother's reaction to news of his marriage was apparently well founded, because while Anna sent, "hearty greetings, presents you with two cheeses, one with caroway seeds and one Edam cheese," through Jan Baptist, she did not respond directly to Jeremias about his marriage. ${ }^{37}$ Her silence about his marriage troubled Jeremias and he desired some word from her about it. In May 1663, he wrote to Jan Baptist, "I am longing very much to have one (letter) from her (Anna) and should be pleased and happy to know how she reconciles herself to it that I thus entered the married state. ${ }^{38}$ He finally wrote to Anna again in August 1663, which was his first letter to her since writing her about his marriage. In the August 1663 letter he expressed his desire to hear from her, stating, "The reason why since then I have not written to you is that I was always longing to get a letter from you in reply." ${ }^{39}$ Anna did not directly correspond with Jeremias for over twenty months after being informed of his marriage to Maria and then, the occasion was news of the birth of Jeremias' first child, her grandson, Kiliaen.

It may be argued that Jeremias' concern about his mother's reaction to his independent decision to marry was based on bonds of affection. His response to her subsequent silence may have indicated concern for her feelings after she was left out of the decision to marry. Nevertheless, Jeremias van Rensselaer's independent decision to marry Maria van Cortlandt represented departure from social and religious tenets and

\footnotetext{
${ }^{37}$ Ibid., 318.

${ }^{38}$ Ibid., 322.

${ }^{39}$ Ibid., 328.
} 
Dutch law. Owing to the van Rensselaer family's wealth and social position and the importance of marriage in creating ties of affinity and property between families,

Jeremias' independence from his family had greater financial and social significance than for most New Netherlanders. Further, had Anna van Rensselaer known about Jeremias' intent to marry she could have used legal means to prevent it from going forward.

According to seventeenth-century Dutch jurists, Hugo Grotius and Simon van Leeuwen, parental approval or, in the absence of approval, judicial permission, was necessary for children in their majority to marry. ${ }^{40}$ Specifically, Grotius indicated

"persons above (the ages of 25 and twenty, male and female, respectively), whose parents were alive, in the event the parents opposing the the proposed marriage, must summon them before the ministers of the Church, or before persons appointed thereto by the magistrates: and if they failed to appear within fourteen days after they had been advertised of the matter, such neglect was taken for consent; if they appeared, their grounds for opposition were heard, and effort made to compose the differences; this failing, the local magistrates, after cognizance of the circumstances, made such order as seemed to them convenient and reasonable." ${ }^{41}$

While it rarely occurred in the Netherlands, parental objections to the marriages of their adult children sometimes prevented the marriages from going forward. ${ }^{42}$ Simon Schama described a case in which the objections of a Holland father and, after his death,

${ }^{40}$ Grotius, Jurisprudence of Holland, 25-27; Commentaries, 1: 103.

${ }^{41}$ Grotius, Jurisprudence of Holland, 27.

${ }^{42}$ There were no cases of parental objections to the marriages of their adult children in New Netherland. Nevertheless, inasmuch as New Netherland laws were based on the laws of Holland and Friesland, had they desired to stop the marriages of their adult children, parents had that option. 
his widow, to the marriage of their adult daughter were upheld by the Hof van Holland (High Court of Holland, to which cases like this one came on appeal). The daughter was not married to the man of her choice until she was thirty-three years old and then only because she had moved out of the jurisdiction of Holland. Dutch painter, Johannes Vermeer and his affianced, Catherina Bolnes, were so concerned about religious objections to their marriage by Catherina's mother they requested and received from her a notarized affidavit indicating she would not legally oppose the marriage. The reason for their concern was Catharina's Catholicism and Vermeer's Protestantism. ${ }^{43}$

Regardless of the legal rights of parents in preventing the marriage of their children, the marriage bond was considered so permanent that once marriage took place in the legally prescribed manner, the courts in the United Provinces and New Netherland were reluctant to dissolve them. Even when the law and magistrates upheld parents' authority in opposing the marriages of minors, the magistrates sometimes advised reconsideration in order to prevent complications. Publication of banns, a remnant of Catholicism with practical applications in the American colonies and Europe, was not merely a formality before marriage. When publication of banns took place following the procedure prescribed by law, the affianced were usually required to follow through with marriage regardless of subsequent personal decisions to terminate the process. That is, completion of publication of banns on three consecutive Sundays or market

\footnotetext{
${ }^{43}$ Vermeer belonged to the Dutch Reformed Church. Schama, The Embarrassment of Riches, 441-442; Donald Haks, "The household of Johannes Vermeer," in Donald Haks and Maria Christine van der Smee, eds. Dutch Society in the Age of Vermeer, Wendie Shaffer, trans. (The Hague, 1996), 95.
} 
days resulted in recognition of the existence of marriage notwithstanding that confirmation by ceremony had not taken place. ${ }^{44}$

In 1654, Maria Verleth [Varleth] and Johan van Beeck, residents of New Amsterdam and minors, were so intent on marriage despite the objections of their parents, they twice sought publication of banns in defiance of their parents and the law. The father of Johan, Johannes van Beeck, was adamantly opposed to the marriage and blocked the banns before they were completed. ${ }^{45}$ However, the Court of Burgomasters and Schepens of New Amsterdam recommended Johannes van Beeck to reconsider his opposition. The grounds for their recommendation were religious and social, but not necessarily legal. They believed Johannes should rescind his legal opposition because,

"The danger that in such circumstances matters by long delay might come to be disclosed between the aforesaid young people, which would bring disgrace to both families, as well as on one side or the other.

'Tis true that our Theologians say, and that correctly, that we must not tolerate or permit lesser sins, in order thereby to avoid greater ones. Therefore, we think (with due submission) that by a proper solemnization of marriage (for the Apostles to the Hebrews calls the

\footnotetext{
${ }^{44}$ However, in New Netherland an ordinance was published that punished couples who did not follow through with a ceremony in a church or before a magistrate with a fine of 100 florins per month. O'Callaghan, Laws and Ordinance of New Netherland, 1638-1674 (Albany, 1868), 328-329, [hereafter cited as LO]. See also, $R N A, 1: 38$ and 2: 304. The New Netherland ordinance regarding the necessity of a ceremony may have been based on the 1580, Orodontie van de Policien binnen Hollandt (Political Ordinances of Holland) which, while it placed no requisites on form, bound couples to publication of banns and a ceremony in a church or before a magistrate. J.W. Wessels, History of Roman-Dutch Law, (Cape Colony, 1898), 438439; Shattuck, "A Civil Society," 25.

${ }^{45}$ The court records sometimes used the same name for the elder and junior van Beeck. Only the context reveals the difference. For clarity in this chapter, I use Johan to refer to the younger and Johannes to refer to the elder.
} 
marriage-bed honorable) the lesser and greater sins are prevented." 46

The Court of Burgomasters and Schepens recognized what Johannes van Beeck refused to acknowledge. His son was determined to marry Maria Verleth regardless of objections and, the law gave only limited ability to prevent the marriages of their children to unacceptable spouses. Johan and Maria were eventually married, but only after absconding to Connecticut where a ceremony in a Congregational church was held. $^{47}$

Johan van Beeck's death in the Indian uprising of September 15, 1655, brought a tragic end to his marriage with Maria. ${ }^{48}$ They had been married less than a year when Johan was killed. Despite the Court of Burgomasters and Schepens recognition of the legality of the marriage, Johan's brother, Joost van Beeck, took up the torch for his father and opposed Maria's claims as Johan's widow. He repeatedly challenged Maria's right to his brother's property, including several letters that had arrived by ship after Johan's death. Joost even refused to act as a guardian of his dead brother's child.

\footnotetext{
${ }^{46} R N A, 165$. The reference to Hebrews refers to the passage that it is better to marry than burn in lust.

${ }^{47}$ Esther Singleton, Dutch New York (New York, 1909), 213-214; At the request of Johannes van Beeck, the marriage was initially declared illegal by the Court of Burgomasters and Schepens. However, when the legality of the marriage was challenged the following year, the magistrates rescinded their earlier decision. They feared the consequences of declaring illegal a marriage effected in another jurisdiction and through a different Protestant sect. In Jurisprudence of Holland, 25, Grotius indicated that prior to the Orodontie van de Policien Hollandt of 1580, couples who were required to obtain consent and married without it were punishable by law. Nevertheless, the marriage could not be nullified.

${ }^{48}$ Fernow, Minutes of the Orphanmaster's Court of New Amsterdam, 1: 3.
} 
However, despite his efforts to prevent official recognition of legal ties between his family and the Verleth family through Maria and her child, the Court of Burgomasters and Schepens and Orphanmaster's Court of New Amsterdam consistently upheld Maria's rights as Johan's widow. ${ }^{49}$

When viewed in the context of the seventeenth century perception of marriage as an insoluble union, the events in the Verleth-van Beeck litigation take on greater significance than when considered as an isolated incident. The underlying reason for the opposition by the van Beeck family may have been recognition of the permanent ties of property and, in time, perhaps affinity, with the Verleth family that would be created by the marriage of Johan and Maria. ${ }^{50}$ Further, regardless of Joost van Beeck's efforts to prevent legal recognition of Maria's status as Johan's widow, the van Beeck's may have understood that if the Court recognized the validity of the marriage, the ties between the families would be irrevocable.

The Court's recommendation to Johannes van Beeck that the marriage of his son to Maria Verleth be allowed to go forward shows the practical application of law in New Netherland. While the law was clearly in Johannes' favor, the Court recognized its limits in preventing behaviors unacceptable to religious tenets and social standards. It

\footnotetext{
${ }^{49}$ Ibid. For suits against Maria Verleth brought by Joost van Beeck see, RNA, 2: passim.

${ }^{50}$ It is interesting to note Maria's father, Casper Verleth, initially joined with Johannes van Beeck in opposition to the marriage of his daughter to Johan. However, he withdrew his objections prior to the Court of Burgomasters and Schepens recommendation the marriage be allowed to go forward. Ibid., 1: 165.
} 
was better for the couple to marry than risk an out of wedlock pregnancy. ${ }^{51}$

As complicated as the exigencies of the colonial American environment made creation of marriages in Dutch tradition, legal termination of marriages followed Dutch precedent established in Europe. While Dutch law afforded opportunities for marital dissolutions, qualifications were built into the law that prevented dissolutions on specious grounds. Important among them was repeated insistence on reconciliations. For example, Merritje Joris accused her husband, Nicolaas Boot, of abusing her. Notwithstanding the illegality of spousal abuse under Dutch law and its inclusion by Merritje among her reasons for request of dissolution, the Court of Burgomasters and Schepens neither prosecuted Boot nor acted with haste to bring about a dissolution. Indeed, they repeatedly insisted on reconciliation between Joris and Boot. However, their decisions were wholly consistent with Dutch law.

According to seventeenth-century jurist, Hugo Grotius, an important qualification limited spousal abuse as grounds for legal separation. Specifically, only repeated instances of abuse were sufficient to grant separations. ${ }^{52}$ However, while it may be presumed the law referred to physical abuse, Grotius did not specify. ${ }^{53}$ Further,

${ }^{51}$ Other considerations of the magistrates may have been the potential for further litigation in the event of birth of an illegitimate child and the possibility that such a child would become a public expense. Sullivan, Punishment of Crime in Colonial New York, passim, makes this point about magistrates in Albany.

${ }^{52}$ Grotius, Jurisprudence of Holland, 29.

${ }^{53}$ Merritje Joris' assertion that Boot had, "diverse times shut her out," implies what the law considered abuse went further than physical violence against her person. $R N A, 2: 335$. 
he related with ambiguity that, "long continuance of abuse," established grounds for marital dissolution. ${ }^{54}$ Therefore, the magistrates in Holland and New Amsterdam were at liberty, with consideration of legal precedent, to interpret what constituted abuse and how much was sufficient for granting legal separations. In the circumstance of Nicolaas Boot and Merritje Joris, Boot was never formally tried for abusing her even though she made the accusation on at least two occasions. The first time was on February 18, 1656, and the second was September 18,1663, when she cited his abuse as the reason why she created a public disturbance for which she was arrested and threatened with banishment. ${ }^{55}$ More significantly, after the second incident, Nicolaas Boot repeated his request for a legal separation from Merritje, which was five years and seven months after making the request the first time. Nevertheless, still hopeful the couple might reconcile their differences after the 1663 incident, the magistrates reported, "having heard parties find no sufficient reason to separate parties from each other, but order them to live in peace."${ }^{.56}$

Despite efforts of the Court of Burgomasters and Schepens, differences between Boot and Joris were never reconciled. Interestingly, it was action by Merritje Joris that brought about final dissolution. She requested the Court appoint arbiters to settle her differences with her husband. Govert Loockermans and Mattheus de Vos were chosen for the task. They were ordered to, "exert every possible means to reconcile parties to

\footnotetext{
${ }^{54}$ Grotius, Jurisprudence of Holland, 29.

${ }^{55} R N A, 2: 335 ; 4: 304$.

${ }^{56}$ Ibid.
} 
each other if possible, to arrange the matter, and not coming to any arrangement to report their conclusions to the Court." ${ }^{57}$ Loockermans and de Vos decided reconciliation was not possible and recommended to the Court that Nicolaas Boot should pay Merritje Joris a yearly maintenance and that she be required to inventory the couple's silverware. In effect, after many unsuccessful efforts to reconcile the couple and with great reluctance, the magistrates were forced to recognize the marriage could not be saved and that Boot, Joris, and likely the community at large, were better served if they parted ways.

However, what gave Merritje Joris confidence to believe she could support herself without a husband? It may be argued that life with Nicolaas Boot had become so unbearable she was forced to ignore the financial consequences of separation. In addition to abuse, Joris complained, "she has not slept with him in a long time, but were she a younger woman he would have more affection for her." 58 Or, she may have counted on a court ordered maintenance like the one the magistrates ended up granting to her. ${ }^{59}$ However, the latter argument is not tenable because while Joris may have been confident she would receive some maintenance, she could not have anticipated the amount the Court would grant.

\footnotetext{
${ }^{57}$ Ibid., 324.
}

${ }^{58}$ Ibid., 2: 335. Joris made this complaint when the couple's differences were first brought before the magistrates. Therefore, it was not a factor in the later granting of a separation. Was Boot having an affair? The record does not reveal it if he was.

${ }^{59}$ The Court of Burgomasters and Schepens granted her, "twelve hundred pounds of good Virginia tobacco," per year. Ibid., 4: 328. 
I argue Merritje Joris was confident in her ability to support herself financially based on her record of management of her own financial affairs and those of her family, including her husband. The evidence is specific and implied. First, when Nicolaas Boot initially filed a complaint against his wife, she asserted financial independence from him by declaring her ability to pay for her own drinking. ${ }^{60}$

The financial independence Joris asserted in the first record of the couple's legal request for court intervention in their differences may have come about through her role as the wife of a merchant-trader who was frequently away on trading missions. In addition to handling accounts for his business activities, Joris transacted business for herself. Acting in her own behalf and in concert with her husband's interests, Joris frequently appeared in the Court of Burgomasters and Schepens of New Amsterdam in pursuit of unpaid debts and as a defendant in collections brought by others. For example, on March 6, 1656, she defended herself against Arent Calebuys who accused Joris of, "lifting," 33 florins, "contrary to the order of the Court, which had arrested." He requested, "she shall prove it belongs to her." Joris produced an account that showed eleven florins of the money was owed to her and offered to swear an oath that another eleven was due to her. ${ }^{61}$

In the next session of the Court of Burgomasters and Schepens, March 13, 1656, Joris was the plaintiff in a suit in which she demanded 234.09 florins from Jacob van

${ }^{60}$ Ibid., 2: 335.

${ }^{61}$ Ibid., 58. Lifting refers to taking monies the court ordered sequestered for payment of a debt. In this case it appears Calebuys accused Joris of accepting money in payment of a debt which he had sequestered from an unrecorded third party. 
Cowenhoven. As in the previous session, she produced a written account showing the debt was owed. However, in this instance the debt was owed for business conducted by her husband. Van Cowenhoven maintained that while he did not refuse Joris what legally belonged to her, he wished to reach a settlement with her husband. ${ }^{62}$

These records and others indicate Joris was handling finances for her own accounts and her husband's trading ventures. The latter may have been because Boot was frequently absent. Like the "deputy-husbands," of New England described by Laurel Thatcher Ulrich, Joris' efforts enabled her husband to be absent for long periods while she handled accounts at home. This enabled him to extend the capacity of his business. ${ }^{63}$ Yet, Joris' role was very much unlike that of most English wives in America because she was Dutch and living under Dutch law. Contrary to most English wives described by Ulrich and other historians of early American women, Joris' activities describe what was common for Dutch wives in America rather than what was permissible. $^{64}$

The court records of New Netherland indicate many wives acted in their own interests and those of their families in transacting business affairs. Martha Shattuck found that all of the identified married women of Beverwijck (Albany) represented

${ }^{62}$ Ibid., 60.

${ }^{63}$ Ulrich, Good Wives, 35-50.

${ }^{64}$ Ibid., 36; Elizabeth Dexter, Colonial Women of Affairs: Women in Business and the Professions in America Before 1776 (Boston and New York, 1924); Spruill, Women's Life and Work, 165. 
themselves in court and at least fifteen represented their husbands. ${ }^{65}$ The records of the Court of Burgomasters and Schepens of New Amsterdam reflect similar levels of activity by married Dutch women. More importantly, when asked to provide specific information about their accounts, it was common for husbands to defer to their wives. In January 1654, Adriaen Keyser sued “[Jan] Harmensen the Cooper” for a debt of 49 florins, 12 stuivers. It was a debt Keyser claimed had been outstanding for two years. Harmensen maintained ignorance; stating, "that there was something due at that time, but as his wife has gone to Fatherland, and he does not know if she has paid pltf.. he requests delay until his wife's return." ${ }^{66}$ Similarly, in March 1656, Jacob van Cowenhoven sued Tuenis Kraey for seven hundred florins. Kraey claimed ignorance of the account because, "he would never account with him [van Cowenhoven], but always with his wife." 67

Regardless of the extraordinary responsibilities of Dutch wives and the legal avenues for dissolution of marriage, surprisingly few wives sought litigation against their husbands. Identically, few husbands sought legal resolution to differences with their wives. Several factors account for this. As stated, religious, social, and legal prohibitions militated against marital dissolution. Another reason was that some couples and individuals tried to end their marriages without involving the courts. That

${ }^{65}$ Shattuck, "A Civil Society," 162-163.

${ }^{66} R N A, 1: 147$. While the records do not reflect prolific instances of wives' independent travel abroad, their absences from New Netherland and their husbands to attend business in the Netherlands was not unusual.

${ }^{67}$ Ibid., 2: 57. 
is, some individuals tried illegal separations. While Anneke Schaets, who moved from Albany to New York City after her marriage to Thomas Davidse[n] Kikebull, eventually reconciled with her husband, she initially appeared resolute in her decision to illegally separate from him. Schaets left Kikebull in 1681 and returned to Albany, during the proprietary period of New York history, while Lieutenant Governor Anthony Brockholls served as acting governor in the absence of Edmund Andros. She returned to her father, Domine Gideon Schaet's, house in Albany. After speaking with Kikebull, acting Governor Brockholls directed the Court of Albany, Rensselaerswijck, and Schenectady to order Schaets' return to New York City and her husband. Following the acting Governor's directive, the Court, "notified and expressly ordered [Anneke] by the first yacht that will sail ... to depart for New York [City] with your children to your lawful husband. ${ }^{96}$

It is unsurprising an English governor directed the return of a Dutch wife to her husband, particularly a wife who had absconded with the couple's children. In the early modern period in England, husbands were legally entitled to lock up their wives if the latter absconded with their children. ${ }^{69}$ There was a tradition of patriarchal conservatism in laws governing marriage in England that transferred to the American colonies.

Furthermore, the Duke's Laws, which governed most of New York during the

\footnotetext{
${ }^{68}$ Van Laer, Minutes of the Court of Albany, Rensselaerswijck, and Schenectady 3 vols. (Albany, 1920), 3: 120-121, [hereafter cited as MCARS]. For Brockholls' roles in early New York see, Robert Ritchie, The Duke's Province: A Study of New York Politics and Society, 1664-1691 (Chapel Hill, 1977); and, Stephen Saunders Webb, 1676: The End of American Independence (Cambridge, MA. and London, 1985).

${ }^{69}$ Stone, Broken Lives, 18.
} 
proprietary period, reflected that conservatism. ${ }^{70}$ For example, under the Duke;'s Laws, wives who had left their husbands, "Causelessly," were subject to forfeiture of their dowries. ${ }^{71}$ More applicable to the Anneke Schaets case, but not enforced against Anneke's father, Domine Gideon Schaets, was a law that stated, "No man shall harbour, conceal or detain Contrary to the concent of the Husband any Married woman, upon penalty of five shillings for every hour that such Married woman remains under his roof." 72

Anneke Schaets was eventually reconciled to her husband, but the road to rapprochement was tortuous. She was initially forced to return to Kikebull, but "she was ... obstinate and would not depart without interference of the schout and constable." ${ }^{73}$ After her forced return to New York City, she fled again to her father, who was then sued by Kikebull for harboring her, presumably under the Duke's Laws prohibiting the harboring of an absconding wife.

During the hearing of Kikebull's suit, Anneke reported to the magistrates, "he [Kikebull] is not a man with whom she can live and that she would prefer to be dead or

${ }^{70}$ The Duke's Laws were introduced in 1665 , but were never uniformly applied although their enforcement increased throughout the colony during the proprietorship. The Duke's Laws came into disuse in 1691 following Leisler's Rebellion. Goebel, "The Courts and the Law in Colonial New York," 269.

${ }^{71}$ Charles Z. Lincoln, ed. The Colonial Laws of New York from the Year 1664 to the Revolution, 5 vols. (Albany, 1896), 1: 32.

${ }^{72}$ Ibid. 46. It is unknown if Gideon Schaets was not prosecuted because he was Anneke's father or because he was a clergyman. The law was apparently written without thought of blood relations to absconding wives.

${ }^{73}$ MCARS, 3: 133. 
imprisoned for life rather than live with him. ${ }^{, 74}$ In consideration of her expression of inflexibility in a public forum, it is surprising Anneke reconciled with Kikebull. However, the records hint at why she did so. While the Court was waiting for the arrival of witnesses called by Anneke Schaets to testify about Kikebull's behavior toward her, court-appointed mediators interceded. The mediators included her father and two aldermen from New York City.

The mediators were successful in their efforts to reconcile Schaets and her husband as evidenced by Schaets' reversal of her declaration not to live with Kikebull under any circumstances. The record intimates what the mediators devised in order to convince Schaets to reconsider her position. Recorded in the minutes are gender specific pledges given by each spouse to live together in peace as wife and husband. For his part, Kikebull also requested court-appointed observers, "to supervise his good conduct." ${ }^{75}$ Did Anneke Schaets insist on Kikebull's agreement to outside supervision? There is no way to be certain. However, her insistence and his acquiescence would have been consistent with her decision to return to him after she had adamantly refused to do so.

The Schaets-Kikebull litigation also subtly reflected gender-based expectations in Dutch marriages. While the records do not specify the nature of Kikebull's behavior that caused Schaets to leave him, Domine Gideon Schaets' provision of sanctuary to his daughter and Kikebull's agreement to observers of his behavior upon reconciliation

\footnotetext{
${ }^{74}$ Ibid., 149.

${ }^{75}$ Ibid., 148-151.
} 
implies spousal abuse. While the Duke's Laws forbade harboring an absconding wife, Domine Schaets may have escaped prosecution because of another of the Duke's Laws. It indicated that wives could seek refuge from physically abusive husbands. ${ }^{76}$

The records do not provide enough information to know why Anneke Schaets chose to abscond from her husband rather than seek legal intervention. We cannot be certain she even considered intervention by the civil authorities. Given her eventual reconciliation, perhaps she never intended to make the separation permanent. However, one reason why she may have avoided litigation against her husband was social and legal insistence on marital insolubility notwithstanding spousal abuse, which was consistent with Dutch and English culture in Europe and America.

While the colony was still under Dutch rule, prior to her marriage to Kikebull, Anneke Schaets was involved in an affair with Arendt van Curler. Van Curler was married and a prominent member of the local and provincial governments before and after English acquisition of New Netherland. ${ }^{77}$ Owing to van Curler's prominence and perhaps that of Anneke Schaets' father, but more so because of the birth of an illegitimate child to Anneke and van Curler, the affair became public knowledge. The affair was the subject of gossip and innuendo about Anneke's character for several years

${ }^{76}$ Lincoln, The Colonial Laws of New York, 1: 32.

${ }^{77}$ At one time Curler represented the director of Rensselaerswijck. He was also an Indian agent and one of the founders and Schenectady. He was so respected by the Iroquois, they continued to refer to all English governors by his name. Sullivan, Punishment of Crime in Colonial New York, 23, 141; Oliver Rink, Holland on the Hudson: An Economic and Social History of Dutch New York (Ithaca, 1986), 222; Van Laer, The Van Rensselaer Bowier Manuscripts (Albany, 1908), 817. 
after it ended and affected her father's roles as a clergyman. As the moral and spiritual leader of Beverwijck, Gideon Schaets was caught in a particularly awkward circumstance by his daughter's affair that played out between him and his congregation when he sought to defend his daughter. His daughter's relationship with van Curler affected Gideon Schaets' ability to effectively serve his congregation, which caused concern among local and provincial authorities, including Director-General Petrus Stuyvesant. $^{78}$

While available records reveal the affair between Anneke Schaets and Arendt van Curler occurred, little mention was made of van Curler's wife, Anthonia Slaaghboom. However, it is known that Slaaghboom publicly condemned her husband for it and as a consequence was severely beaten by him. The beating added further grist for the rumor mill. ${ }^{79}$ Nevertheless, like Nicolaas Boot, van Curler was not prosecuted for spousal abuse. The reason may have been because Anthonia Slaaghboom showed no inclination to prosecute him or seek a separation. Inasmuch as adultery was grounds for divorce under Dutch law, she could have chosen that option, but did not. ${ }^{80}$

While Dutch law prohibited abuse of wives by their husbands and long

${ }^{78}$ MCARS, 3: 98-100; Sullivan, Punishment of Crime in Colonial New York, 141143; O'Callaghan, History of New Netherland or New York Under the Dutch, 2 vols. (New York, 1848; rpt., Spartensburg, S.C., 1966), 2: 567-568.

${ }^{79}$ The degree to which the Schaets-van Curler affair affected the local population of Beverwijck is clouded by the absence of records from Fort Orange and Beverwijck during the period when the affair occurred. However, Stuyvesant was compelled to make an inquiry through Johannes La Montagne, schout and vice-director of Beverwijck. Sullivan, Punishment of Crime in Colonial New York, 141, 143.

${ }^{80}$ Ibid., 142; Grotius, Jurisprudence of Holland, 29. 
continuance of abuse constituted grounds for separation from bed and board, Dutch law and its application clearly favored the husbands of discontented wives. Various authors have commented on some of the proprietary disadvantages that accrued to Dutch women when they married. There were some similarities with the femme covert status of English wives in that Dutch wives were considered sub tutela, or under the guardianship of their husbands. ${ }^{81}$ Nevertheless, Dutch law implied reciprocal and even complimentary responsibilities for husbands and wives. Laws that protected community property and property owned separately by wives from the ravages of profligate husbands reflected the Dutch definition of marital partnership. If the law gave husbands superior property rights it also imbued them with responsibilities to be good stewards of the property. Moreover, the law provided wives with options, albeit qualified, for denying their husbands control of property. ${ }^{82}$

In 1659, Schout Nicasius de Sille, the civil officer who arrested Nicolaas Boot for spousal abuse the previous year, petitioned the Court of Burgomasters and Schepens of New Amsterdam for a divorce from his wife, Catharina Croegers. Like Boot, de Sille complained of his wife's drunken behavior in public. In addition, he also complained his wife, "wasted property without his knowledge." 83 In doing so, de Sille acknowledged a husband's legal superiority over property accumulated during marriage.

${ }^{81}$ Morris, Studies in the History of American Law, 128; Biemer, Women and Property in Colonial New York, 1-3; Shattuck, "A Civil Society," 154.

${ }^{82}$ Grotius, Jurisprudence of Holland, 29-33.

${ }^{83} R N A, 3: 90$. 
According to Grotius, even though husbands could alienate and encumber property accumulated during marriage without permission from their wives, wives could not reciprocate. However, wives' roles and interests in property changed as a consequence of commercial expansion of the Netherlands. Wives' authority over property produced by their own hands, e.g., sewing, baking, and brewing, was greatly expanded when the Netherlands experienced rapid commercial growth in the late sixteenth and seventeenth centuries. ${ }^{84}$ Women's traditional domestic roles as wives and mothers were adapted to the changed circumstances in order to maintain the convention of marital partnership. ${ }^{85}$ However, antenuptial agreements and separation of goods also limited husbands' authority over common property. In the former, prior to marriage a contract spelling out respective authority over property was agreed upon. In the latter, Grotius explained, "if she sees her husband is going to reduce her to poverty, she may take proceedings for separation of goods, and have her husband interdicted upon from administering her property." ${ }^{86}$ That is, husbands' control of property was not absolute under Dutch law. Available records indicate Catharina Croegers married Nicasius de Sille with the legal understanding of manus. That is, she was legally under de Sille's guardianship, which included the debility that she could not represent herself in court without her husband's permission. Yet, Croegers appeared in the Court of Burgomasters and

\footnotetext{
${ }^{84}$ Grotius, Jurisprudence of Holland, 31.

${ }^{85}$ This concept is explored in greater detail in chapter 3, "Women and the Colonial Economy."

${ }^{86}$ Grotius, Jurisprudence of Holland, 31.
} 
Schepens of New Amsterdam as a plaintiff and defendant in civil suits on several occasions without her husband. For example, in April 1656, Croegers had the property of Roger Kilvert "arrested," i.e., sequestered, because he had paid his debt to her with poor quality tobacco, which according to Croegers, "was not worth the debt he owed to her." ${ }^{87}$ In 1665, Merritje Joris sued Croegers for fifty guilders, "for half a years wages for her daughter," who was apparently working as a maidservant for Croegers and her family. ${ }^{88}$

Did Croegers have permission from her husband, verbal or otherwise, to represent herself in court as Grotius indicated was necessary for wives under manus? In at least one circumstance prior to his request for a divorce from Croegers, Nicasius de Sille appeared with his wife in the Court of Burgomasters and Schepens. It involved a suit brought by Jacobus Backer in which Croegers was the defendant. However, on the day de Sille appeared with his wife, Backer did not appear and the case was continued. With one further exception, in which de Sille appeared alone for his wife to request dismissal of Backer's suit, he never again represented his wife in court. In one session, on March 13, 1656, in which Backer's suit was again continued owing to his absence, Croegers responded to the suit in writing. She offered to produce documents that proved she had paid the debt in question. Interestingly, it was only after his wife's assertion of proof through documentation that the debt was paid that de Sille appeared at

\footnotetext{
${ }^{87} R N A, 2: 86$.

${ }^{88}$ Ibid., 191, 194.
} 
a later session to request dismissal on her behalf. ${ }^{89}$ It is clear Croegers was managing at least some of the couple's financial affairs and that they treated their marriage as a partnership prior to their falling out.

Catharina's ability to manage accounts prior to separation from her husband served her well afterward. On October 28, 1668, Sara Bridges sued Croegers for a debt that Croegers maintained was owed by her estranged husband. As she had done in the Backer litigation, Croegers produced written proof indicating the debt was owed by de Sille. In light of the evidence she produced, the Court of Burgomasters and Schepens ordered de Sille to pay the debt and court costs. ${ }^{90}$

Clearly, under Dutch law wives could not appear in court and dispose of property without the written, i.e., given the power of attorney, or verbal approval of their husbands. ${ }^{91}$ Nevertheless, the presence or absence of written approval by husbands is rarely mentioned in the records as grounds for denial of litigation. Further, it is impossible to measure how many wives were acting with the formal or informal verbal approval of their husbands. However, based on appearances in court of wives like Catharina Croegers, Merritje Joris, and many others whose marriages were more secure, management of property and finances was a function of Dutch wives that was accepted and perhaps expected by their husbands. Objections to their wives' management of

${ }^{89}$ Ibid., 2: 47, 54, 62, 71. Backer was again absent on the day Croegers produced the documentation, which is why the case was continued and resulted in de Sille's appearance in his wife's place.

${ }^{90}$ Ibid., 6: 149.

${ }^{91}$ Grotius, Jurisprudence of Holland, 29; Shattuck, “A Civil Society,” 154. 
property and finances by husbands also rarely appears in the records of New Netherland. ${ }^{92}$ Therefore, the appearance in court of wives with their husbands and independently to protect family and personal interests reveals legal acceptance of responsibilities for women that was uncommon in other western cultures. Moreover, it reveals wives' elevation to positions of importance in the economic and social structures of New Netherland society.

Wives' exercise of responsibility for financial affairs and management of property does not appear as a major factor in bringing about decisions to seek legal intervention in dysfunctional marriages. However, it was present in marriages in which spouses sought dissolutions. For example, as late as 1670, when Catharina Croegers and Nicasius de Sille were living apart and disagreeing in court about a division of property, the Mayor's Court of New York City appointed a commission to attempt a reconciliation of the couple. The commissioners found de Sille, "more inclined [to a reconciliation] than his wife." 93

The events in the de Sille-Croegers litigation are instructive for several reasons. First, Catharina Croegers' resolution to end her marriage represents disintegration of a marriage that at one time was considered a partnership by both spouses. However, while de Sille's complaints against his wife were used in an effort to bring about a separation, Croegers' complaints about her husband were not used in conjunction with

${ }^{92}$ Shattuck, "A Civil Society," 163, found only one court case in Beverwijck of a husband's objection to his wife's role as a financial administrator.

${ }^{93} R N A, 6: 227$. 
requests for a dissolution. Yet, when reconciliation was made optional rather than mandatory by the magistrates, Croegers chose dissolution. Her resistance to another compromise with her husband was resolute in the absence of a maintenance agreement and property settlement. It is clear Catharina had been living independently of her husband for some time following de Sille's initial complaint about her behavior. However, whether her decision to resist reconciliation was based on abject despair of living with de Sille again, confidence in her ability to support herself, or a combination of factors, when presented with an opportunity to reconcile with him, she refused. ${ }^{94}$

Inasmuch as final dissolution of the de Sille-Croegers marriage occurred in 1670, it was adjudicated by English authorities. English administrators may have accepted the outcome because litigation began while the colony was still under Dutch rule. However, when litigation for dissolutions originated in English administered courts, magistrates were as reluctant as their Dutch predecessors to grant them. In January 1672, in the Court of Sessions at Kingston [formerly Wiltwijck], Elizabedt Crafford petitioned for a divorce from her husband, Jeroen Dowersen, who had left her. Appearing by order of the Court, Dowersen maintained Crafford, "cannot serve him as wife, and will not serve him as servant, and further says that she has said she never loved him, but says that he never said that he would leave her." After investigating the differences between Crafford and Dowersen, the Court found no grounds for a

\footnotetext{
${ }^{94}$ The records indicate de Sille had two adult daughters from a previous marriage; therefore, maintenance of children was not a consideration. The record further indicates that on an unspecified date in 1670, de Sille disappeared and was not heard from again. $R N A, 6: 228$.
} 
separation and Dowersen was ordered to inventory his effects and give security to prevent his absconding. Nevertheless, the order of the Court was insufficient to bring about a reconciliation and four months later, in April 1672, acting on complaints from Crafford, the Kingston Court ordered Dowersen, "to support his wife, as a legal husband is obliged to support his lawful wife." 95

The Crafford-Dowersen and de Sille-Groegers cases and other records of marital litigation in early New York are instructive about the difficulties that developed after English administrators assumed authority. English administrators tried to apply English jurisprudence to a majority non-English, non-Anglican population without the adequate legal structures available to do so. ${ }^{96}$ Therefore, marital litigation cases like CraffordDowersen and de Sille-Croegers illustrate the unique legal circumstances encountered by English administrators during the proprietary period of New York history. ${ }^{97}$ The proprietor appointed governors and their subordinates were charged with the often contradictory responsibility of conforming to the laws of England while peacefully governing a majority foreign population. Governing a non-English, non-Anglican, but

${ }^{95}$ Kingston Papers, 2: 478-479, 481.

${ }^{96}$ Increased application of common law to American cases had not yet come to fruition and unlike England, there were no ecclesiastical courts in America. Described as labyrinthine by legal scholars, the court system in New York during the proprietorship of James, duke of York, and after his succession to the throne, King James II, conferred broad adjudicative powers on governors and through them, their councils. Herbert A. Johnson, "The Prerogative Court of New York, 1686-1776," in Johnson, Essays on New York Colonial Legal History (Westport, CT., 1981), 66; Goebel, "The Courts and the Law in Colonial New York," 253-259.

\footnotetext{
${ }^{97}$ Those administrators were often Duke appointed governors, who were the final judges in many marital litigation cases.
} 
Protestant Christian population accustomed to adjudication under Dutch law while bringing about English institutions was awkward and painstaking. ${ }^{98}$ Therefore, while English authorities often denied requests for dissolutions of marriages, at other times they granted them. The granting of dissolutions by English authorities has perplexed scholars owing to the absence of information about their legal foundations.

There were a total of six marital dissolutions granted by two proprietary governors. Francis Lovelace granted four divorces and one annulment and Edmund Andros granted one divorce. While there is evidence these dissolutions were based on Dutch precedent, the governors did not necessarily use the dissolutions granted under Dutch rule to speciously establish a common law for the colony in marital litigation cases as asserted by Mateo Spalletta in $1955 .{ }^{99}$ Diverse variables likely influenced initial decisions to hear marital litigation cases and helped to determine the validity of grounds for dissolutions.

Matthias Nicolls, secretary of the province of New York and perhaps the author of the Duke's Laws, and Thomas Willet, who acted as a consultant in formation of the laws had practical experience in the government of Plymouth colony. ${ }^{100}$ From that experience, they acquired a view of marriage as a civil contract subject to administration by the courts. ${ }^{101}$ That may explain why the Duke's Laws included provisions for marital

\footnotetext{
${ }^{98}$ Ritchie, The Duke's Province, 34-36.

${ }^{99}$ Spalletta, "Divorce in Colonial New York," 435, 435n20.

${ }^{100}$ Nicolls' authorship of the Duke's Laws is debated by historians.

${ }^{101}$ Goebel, "The Courts and the Law in Colonial New York," 250.
} 
dissolutions, which was contrary to English precedent. Specifically, swearing a false oath to the Justices [about previous marriages or affinity], willful or unintentional desertion, and adultery were listed as grounds for marital dissolution. ${ }^{102}$

All of the dissolutions granted by Lovelace and Andros were based on adultery or sexual misconduct. ${ }^{103}$ Therefore, granting dissolutions was consistent with the Duke's Laws, but did not conform to the laws of England. In granting divorces to Daniel Denton and Thomas Pettit on grounds their wives committed adulteries, Lovelace indicated his decision conformed, "to the laws of this government, as well as to the practice of civil law and the law of our nation of England." 104 However, while his reference to English law was ostensibly incorrect, it may have been a pro forma recognition of the ultimate authority from which he acted rather than reference to a specific body of English law. The royal charters granted for the colonies of Massachusetts Bay, Maryland, and to James, duke of York for New York, included

${ }^{102}$ Spalletta, "Divorce in Colonial New York," 426.

${ }^{103}$ The annulment granted by Lovelace was based on the potential for adultery. Eleazar Leveridge had been unwilling or unable to have sexual intercourse with his wife, Rebecca Leveridge, during their seven years of marriage. In granting the annulment, Lovelace indicated one of the intentions of marriage is, "to Extinguish those fleshly desires \& appetites incident to Humane nature." Further, since the marriage had not been consummated, in the words of Lovelace, it was a, "pretended marriage," and therefore never legally existed. Victor Hugo Paltists, ed. Minutes of the Executive Council of the Province of New York, Administration of Francis Lovelace, 1668-1673, 2 vols. (Albany, 1910), 1: 336 [hereafter cited as Executive Council Minutes]. The divorce granted by Andros was based on a petition by Katherine Lane that her husband, Daniel Lane, had committed adultery and incest with their daughter. Christoph, ed. Records of the Court of Assizes, 155-156, 161.

${ }^{104}$ Paltists, Executive Council Minutes, 2: 751; Spalletta, "Divorce in Colonial New York," 428. 
clauses with similar wording. In addition, to which body of English law did Lovelace and the charters refer; ecclesiastical, common, equity, or local? ${ }^{105}$ In the circumstance of Massachusetts Bay and New York, lack of specificity resulted in inclusion of legal provisions for marital dissolution. ${ }^{106}$

Another consideration for early English administrators in New York was Dutch legal precedent and jurisprudence. That is, there are indications of English familiarity with the Dutch jurisprudence upon which dissolution cases had been decided when the colony was under Dutch rule. In writing the Duke's Laws, Matthias Nicolls had access to the ordinances of New Netherland. ${ }^{107}$ While nothing in the ordinances specifically addressed marital dissolution, the legal grounds for marital dissolutions that were granted were consistent with Dutch law as it was practiced in Holland and other Dutch provinces. ${ }^{108}$ In addition, Edmund Andros' decision to grant a divorce may have been influenced by his personal knowledge of Dutch jurisprudence acquired along with the Dutch language during his years of service to the Stuarts ensconced at The Hague between 1651 and $1661 .^{109}$

${ }^{105}$ Marital litigation in England was the prerogative of the ecclesiastical courts. While dissolutions were rarely granted by the ecclesiastical courts, they did so in extreme cases. Stone, Road to Divorce, 141-230; Shoemaker, Gender in English Society, 107-108.

${ }^{106}$ Friedman, History of American Law, 38-39; Ritchie, The Duke’s Province, 31.

${ }^{107}$ Ibid., 34.

${ }^{108}$ Grotius, Jurisprudence of Holland, 23-29.

${ }^{109}$ Webb, 1676: The End of American Independence, 310-312. 
Finally, the divorces granted by Lovelace and Andros were consistent with the hybrid development of English law in New York during the first few decades of English rule. The hybridism of early New York jurisprudence and specifically the way marital litigation was adjudicated were mandated by the necessities of governing a population accustomed to a culturally and religiously distinct jurisprudence. In receiving the charter for New York from his brother, Charles II, James was required to follow a policy, "fit and necessary," for the circumstances so long as it was not, "contrary to the laws and statutes of this Our Realm of England but as near as may be agreeable thereunto."110 James' instructions to Richard Nicolls have not survived, but based on Nicolls' actions and those of subsequent proprietary governors, the governors of the colony were given broad discretionary power within a fixed policy of executive authority. ${ }^{111}$ Owing to their instructions, the difficulties inherent in governing a nonEnglish, non-Anglican, Protestant population and the absence of ecclesiastical courts, early New York governors had little recourse but to hear testimony, determine an outcome based on the merits of each case, and on occasion, grant dissolutions to irreconcilable couples.

For reasons not revealed in the records, there were no more marital dissolutions after $1675 .^{112}$ More importantly, there were no dissolutions between 1675 and 1691.

${ }^{110}$ O’Callaghan, NYCD, 2: 296-297.

${ }^{111}$ Ritchie, The Duke's Province, 34-36. Theoretically, appeals could be made from the Court of Assizes, made up of the governor, his council, sheriff, and justices of the peace, to the king.

${ }^{112}$ Spalletta, "Divorce in Colonial New York," 435-436. 
After 1691, in the wake of Leisler's Rebellion, there was an attempt to reduce confusion in the court structure of New York through passage of the "Act for Establishing Courts of Judicature." The Act signaled fruition of legal anglicization of New York and more specifically increased use of English common law precedent by the courts. ${ }^{113}$

Several explanations for the absence of marital dissolution cases in court records between 1675 and 1691 are possible. From a practical standpoint, given the small number of total dissolution cases under the Dutch government and early English proprietary government, the most probable reason may be no one sought litigation against their spouses.

More importantly, the period of the 1670s saw accelerated anglicization of the colony. The Dutch predilection for resolving domestic differences privately within their families was a factor that may have kept Dutch couples out of courts administered by English authorities. Dutch and English legal methods for handling domestic discord were subtly different. Insistence on reconciliations ordered by Dutch magistrates were usually effected through private action rather than appointment of arbiters. The position of magistrates, which reflected Dutch law, was family members were more likely to bring about reconciliations than court appointed mediators. In the Court of Albany, Rensselaerswijck, and Schenectady, which retained Dutch jurisprudence longer than some areas of New York, the court appointed mediators who tried to resolve the

${ }^{113} \mathrm{Up}$ to that point adjudicators relied on previous decisions by earlier governors. Goebel, "Courts and the Law in Colonial New York," 260-261; Johnson, "The Advent of Common Law in Colonial New York," in George Billias, ed. Law and Authority in Colonial America (New York, 1986), 74-91: 86. 
differences between Anneke Schaets and Thomas Davidtsen Kikebull included Anneke's father. ${ }^{114}$ In the case of Rebecka and Eleazar Leveridge, Governor Lovelace ordered appointment of commissioners to discover the couple's differences rather than allow a hearing in open court. The sensitive nature of the couple's differences, i.e., male impotence, which may have prevented Lovelace from allowing and open hearing, resulted in the appointment of a commission that subsequently ordered examinations of Rebecka and Eleazar by qualified medical practitioners. Notwithstanding, Rebecka's father, Nicolas Wright's role in representing his daughter before the court, investigation was handled by non-family members. The implication was more formal procedures in marital litigation cases were being introduced. ${ }^{115}$

Another practical factor of jurisprudence reflecting on the absence of marital litigation between 1675 and 1691, particularly among Dutch couples, was the change from Dutch to English language by the courts. When he assumed his duties as governor of New York in 1674, Edmund Andros ordered the change from Dutch to English language by the courts. ${ }^{116}$ It is impossible to ascertain how many people were bilingual in Dutch and English in the colony, but some who were, like Robert Livingston, were much in demand. Livingston provided important services to the provincial government

\footnotetext{
${ }^{114}$ Goebels, "The Courts and the Law in Colonial New York," 254; MCARS, 3: 133.

${ }^{115}$ Paltists, Executive Council Minutes, 1: 331-333; Ritchie, The Duke's Province, 143.

${ }^{116}$ Ibid., 140.
} 
and enjoyed advantages denied to those who were not bilingual. ${ }^{117}$

Increased anglicization of the proprietary period courts and restructuring of the court system that took place in 1691, following Leisler's Rebellion, resulted in greater application of English common law. In England, marital litigation was the prerogative of the church courts, but no such courts developed in colonial America. Therefore, the English common law that developed in colonial America in the eighteenth-century never recognized the legality of marital dissolutions. ${ }^{118}$ Consequently, irreconcilable couples were without recourse to legal dissolutions until after the American Revolution. From the last legal dissolution granted by Governor Andros in 1675 to 1787, couples and individuals desirous of ending their marriages did so illegally. Nevertheless, irreconcilable New York couples were not unique in using illegal dissolutions.

Private separations and more importantly, tacit recognition of them by civil authorities in the American colonies without legal avenues for dissolution of marriage, developed in the absence of ecclesiastical courts. One early American historian related mutually agreed upon private separations were common in the southern colonies of Maryland, Virginia, and North Carolina in the seventeenth and eighteenth centuries. Regardless of the absence of legal sanction, private separations in these colonies were sometimes published in newspapers and followed by remarriage to third parties. ${ }^{119}$

\section{${ }^{117}$ Ibid., 138.}

${ }^{118}$ As indicated earlier, Massachusetts continued to allow civil dissolutions of marriage in the eighteenth-century owing to Puritan foundations that relied on civil recognition of the married state.

${ }^{119}$ Spruill, Women's Life and Work in the Southern Colonies, 183. 
Legally sanctioned marital dissolutions discontinued after 1675 in New York, but contrary to the assertion by Matteo Spalletta, marital litigation did not. ${ }^{120}$ In 1710, Elizabeth Sydenham petitioned the Supreme Court of Judicature for relief from ill treatment by her husband. Five years later in 1715, she petitioned the same court, "for separate maintenance for (from) her husband, George Sydenham." ${ }^{121}$ In May 1709, Vincent Delamontagne was, "ordered to allow his wife and children to live in the great room of his house in Sclavonai in the Bowery Division [of New York City]." ${ }^{122}$ The New York City Court of Quarter Sessions ordered Samuel and Ann Mortimer in 1735, "to maintain their two children (the younger aged 2 months) and to live together as man and wife." ${ }^{123}$ The last example was that of Frederick Williams who was jailed in 1740 for failure to produce, "sureties required by his wife Mary; (and) she has the peace continued against him until he is finally discharged." ${ }^{24}$

Marital litigation was sometimes hidden in New York records under adultery and other indications of domestic dysfunction. Significantly, the above cases ostensibly

${ }^{120}$ Spalletta, "Divorce in Colonial New York," 434.

${ }^{121}$ Paul M. Hanlin and Charles E. Baker, eds. Annotated Minutes of the Supreme Court of Judicature of the Province of New York, 1691-1724, 3 vols. (New York, 1959), 1: 339-340. 1982), 24.

${ }^{122}$ Kenneth Scott, comp. New York City Records, 1684-1760 (Washington, D.C.,

${ }^{123}$ Ibid., 47.

${ }^{124}$ Ibid., 54. 
involved English litigants. ${ }^{125}$ Prosecutions for adultery were sometimes expressions of marital dysfunction and therefore, may be considered marital litigation. However, because English authorities were more ardent than the Dutch in prosecuting adultery, each case must stand on its own merits as an expression of marital dysfunction.

Prosecutions for adultery began within a few years of English acquisition of New Netherland. For example, in 1670, Peter Bucklien was imprisoned and fined for adultery and ordered thereafter to financially maintain the child he fathered with his wife's sister. ${ }^{126}$ After legal dissolutions ceased in 1675, prosecutions for adultery increased. In 1679, Annetie Dircks and her married paramour, Titus Serix, were prosecuted for adultery. Perhaps reflecting an increase in the financial debility of women, Serix was fined an unrevealed amount and court costs while Dircks was given, "7 lashes on her bare back, at the common Whipping Post." ${ }^{127}$ The Court of Quarter Sessions for New York City indicted Henry Cordus, a brick maker, in February 1709 for adultery with Arriantie Delamontagne, wife of the above mentioned Vincent Delamontagne. Vincent Delamontagne refused to accept responsibility for maintenance of his wife and children after Arriantie's prosecution for adultery, but did not sue for

${ }^{125}$ It is possible some of the names were anglicized by the early eighteenthcentury, particularly second generation Dutch. Further, as New York became more anglicized, Dutch women dropped the custom of retaining their patronymic. They increasingly were identified through the names of their husbands.

${ }^{126}$ Christoph, Court of Assizes Records, 115.

${ }^{127}$ Ibid., 256. Another reason for her punishment may have been male enjoyment of its lascivious nature. 
separation or divorce. Rather than allow a private separation that would result in destitution for Arriantie and the Delamontagne children, the court ordered Vincent Delamontagne to at least allow his wife and children to live in his house. ${ }^{128}$

Private separations and adultery were two of several expressions of marital dysfunction after the New York courts stopped granting dissolutions. In 1726, Thomas Byng was executed by hanging for murdering his wife, Martha. ${ }^{129}$ While instances of spousal abuse did not show a substantial increase over earlier periods, neither did they decline. For example, in August 1732, Elizabeth Smith requested a peace bond against her husband, Jepthath, who had been abusing her. ${ }^{130}$ In November 1740, Peter Stoutenburgh had his wife, Margaret, declared non compos mentis, a general legal term embracing all varieties of mental infirmity, claiming he could not care for her. She was sent to the, "house of corrections," ... but, "As she has recovered her senses, it is ordered that she be discharged." ${ }^{\prime 31}$ We cannot be certain Stoutenburgh had his wife committed specifically because of marital dysfunction, but the brevity of her commitment is suspicious. Further, that he was able to have his wife legally committed was indicative of official support of husbands' authority over their wives' behavior. That is, his assertion that he could not care for her may have been stated in order to make her confinement legally tenable.

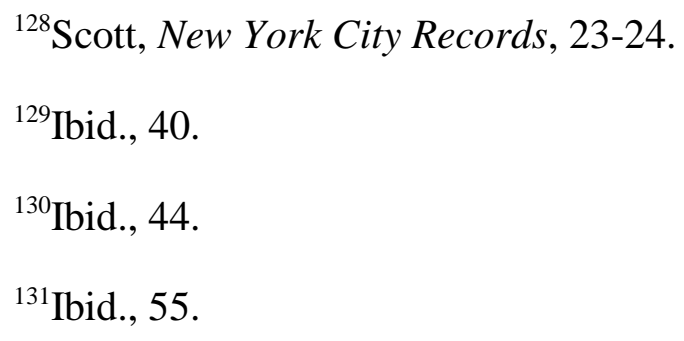


Owing to the presence of large Dutch and Puritan populations in seventeenthcentury New York accustomed to Dutch civil law, early English administrators carefully avoided wholesale changes. The English officials desired to avoid cultural and religious fractures that might incite opposition to their administration of the colony. That helps to explain inclusion of marital dissolution in the Duke's Laws. However, when dissolution cases came before Lovelace and Andros, they balanced local precedent with English procedure and were careful to conform to the sections on dissolution in the Duke's Laws. As with other expressions of cultural hybridism in proprietary New York, expression of law in marital litigation cases indicates anglicization was evolutionary rather than forced on an unwilling population. Intransigence by English authorities in marital litigation and other areas of jurisprudence may have resulted in crystallization of ethnic differences with accompanying and potentially overwhelming immediate and long-range consequences. In allowing legal marital dissolutions, governors like Lovelace and Andros were expressing their desire to avoid substantial divergence from established precedent.

However, English jurisprudence in marital litigation cases was ambiguous owing to the absence of ecclesiastical courts in colonial America. Therefore, a handful of legally sanctioned marital dissolutions in proprietary New York cannot be considered significant anomalies. More importantly, the dissolutions granted by Lovelace and Andros did not serve as precedents for marital litigation for the remainder of the colonial period. Legally sanctioned dissolutions ended in New York as the process of anglicization of law progressed. Use of English procedure and discontinuance of the 
Dutch language in the courts of the colony gave dysfunctional Dutch and English couples two alternatives; they either stayed together or followed extra-legal channels for ending their marriages. There was no other recourse for decidedly irreconcilable couples. However, in that regard they were no different from irreconcilable couples in England and most of England's other colonies in America.

The few circumstances of marital dissolution in New Netherland and seventeenth-century New York offer few definitive conclusions about Dutch society compared to non-Anglican English society in colonial America. However, if we include them in the larger perspective of marriage and marital dysfunction, they provide deeper appreciation for the social, religious, and legal insistence on insolubility that characterized early modern marriage among the Dutch and English. Moreover, they help reveal the subtle cultural differences between the Dutch and English in ways insolubility was expressed.

Marital litigation makes up a small fraction of the total cases included in the extant records of New Netherland and seventeenth-century New York. Like Nicolaas Boot's expression of regret that intervention by the Court of Burgomasters and Schepens of New Amsterdam was necessary to resolve his differences with Merritje Joris, most individuals experiencing marital dysfunction were probably reluctant to reveal their differences in open court. Taking a spouse to court meant private efforts by individual couples and their families to effect reconciliations had failed. As the process of anglicization developed, expressions of which included mandated use of English by the courts and greater attention to insolubility, marital litigation between Dutch couples 
became nearly non-existent. However, even when the colony was administered by the Dutch, requests for separations or divorces were few. Civil dissolution under Dutch law merely provided a safety valve for couples who could not resolve their differences any other way. The process of marital litigation resulting in dissolution was tortuously slow under Dutch law. Illiberal interpretation of Dutch law enforced a policy of insolubility that was supported by Dutch society and the Dutch Reformed Church that resulted in repeated magisterial insistence on reconciliation. The Dutch magistrates made their insistence despite overwhelming evidence of incompatibility. Marital insolubility was characteristic of English culture as well, but legal dissolutions were much more difficult to obtain. Progression of anglicization and greater reliance on English common law by New York courts resulted in extra-legal consequences that were sometimes tragic for irreconcilable couples. As anomalous as the dissolutions granted by Lovelace and Andros appear, they were characteristic of the prudent flexibility English administrators exercised during the transition from Dutch to English law. 


\title{
Chapter Three
}

\section{Women, the Colonial Economy, and Institutional Anglicization}

\begin{abstract}
"To those who say that women are fit for the household and no more, then I would answer that with us, many women, without forgetting the house, practice trade and commerce and even arts and learning."1
\end{abstract}

In the autumn of 1668, cargo bound for New York City languished in the hold of a ship diplomatically named, the King Charles, while it was moored in the port of Amsterdam. The cargo on board belonged to a group of New York City particuliere koopleiden, or merchant-traders. They petitioned the government of King Charles II of

${ }^{1}$ Jan van Beverwijck, Uitnementhyt de Vroulicken Geslachts [On the Excellence of the Female Sex] (Dordrecht, 1643), 211; qtd. in Schama, The Embarrassment of Riches, 419. 
England for an exemption from the laws holding their cargo in port. Specifically, exemption from the Navigation Acts would allow their ship to proceed. ${ }^{2}$ The unfortunate merchant-traders and the owner of the ship, Margaret Hardenbroeck, were caught in the vacillating application of seventeenth-century English commercial policies when an exemption granted in 1667 for three ships per year to sail between New York and the Netherlands was rescinded by the Crown in $1668 .{ }^{3}$ However, with a favorable recommendation from the Board of Trade, in December 1668, the King granted an exemption for the King Charles, "to make one voyage and no more to New Yorke this year only, and to returne againe without any hinderance or molestation ... His Royall Highness do not for the future grant any other Passe or Passes to any Dutch Shipp or Shipps whatsoever to trade to New Yorke." ${ }^{4}$

The order from the Crown came only four years after the English had taken possession of New Netherland. However, the language of the document indicates the British government was reluctant to make any exceptions to the Navigation Acts for the Dutch in New York. More importantly, this was an age of legally circumscribed

${ }^{2}$ O'Callaghan, "Petition of Steven[sen] van Cortlandt and others," NYCD, 3: 178-179. Merchant-trader is used here to refer to entrepreneurs who engaged in transoceanic wholesale and retail trade. Merchant refers to those who participated in local retail trade. My inclusion of intermittent traders, providers of services, and relations between sellers and consumers in this discussion prevented use of the nomenclature, "shopkeepers and merchants," used by Jean P. Jordan, "Women Merchants in Colonial New York," New York History (Oct., 1977), 412-439: 413. Jordan's focus was primarily on those I refer to as merchant-traders.

${ }^{3} N Y C D, 3: 175-176$; Order in Council, Nov. 18, 1668, Ibid., 177-178.

${ }^{4}$ Ibid., 178-179; quote p.179. 
property rights for most married women in Europe and America. Therefore, a greater anomaly was Margaret Hardenbroeck's ownership of the King Charles and her management of transoceanic commercial activities. Hardenbroeck was married to merchant-trader Frederick Philipse, who originally came to New Netherland as a carpenter for the Dutch West Indian Company. His marriage to Margaret enabled him to accrue one of the largest fortunes in seventeenth-century New York. He parlayed their wealth into important political associations with English provincial authorities. ${ }^{5}$ However, if Philipse influenced the favorable recommendation of the Board of Trade for an exemption for his wife's ship, there is no record of it. While Hardenbroeck was among the signers of the petition for an exemption for the King Charles, her husband was not. Nevertheless, Margaret Hardenbroeck frequently acted independently in commercial pursuits. Viewing her activities through the lens of an uncompromising religious conviction, Jasper Dankaerts attributed the eccentricities of Hardenbroeck's commercial activities to "miserable covetousness." Nevertheless, regardless of her motivations, before and after her marriage to Philipse, Hardenbroeck accompanied passengers and cargo in her own ships on transatlantic voyages from the Netherlands to New Netherland and then seventeenth-century New York. It was on one of those

${ }^{5}$ Dankaerts Journal, 258, 253; Booth, History of the City of New York, 829; Ritchie, The Duke's Province, 60.

${ }^{6}$ Dankaerts Journal, 53. The Labadists, were a Protestant (originally Catholic) sect that followed the teachings of Jean de Labadie, a French mystic. Uncharacteristic of Dutch acceptance of different sects and religions during the seventeenth-century, the Labadists were denied full religious expression in Holland and emigrated to Wieward, a village in Friesland. Murphy, "Introduction," Ibid., ix-xlvii: xii-xiv. 
voyages in 1679 that as a passenger, Dankaerts was close enough to Hardenbroeck to observe and judge her activities. ${ }^{7}$

Except for a limited number of elite women, commercial activity on Hardenbroeck's level was rare for married women in England and its colonial dominions in America. However, while independent participation in intercontinental commerce by married women in Europe and America was atypical in most cultures, it was more common among the Dutch. When Hardenbroeck first arrived in New Netherland in 1659 as a factor for her cousin, Amsterdam particuliere koopleiden, Wolter Valck, many women in the colony participated in commerce on one level or another. ${ }^{8}$ In general, there were two levels of commercial activity by married women, but the division is arbitrary. Few women were directly involved in transoceanic trade as merchant-traders like Margaret Hardenbroeck, but most had enough knowledge about markets, keeping accounts, and the legalities of trade to function well within their spheres of commercial activity. Differences between the commercial activities of women like Hardenbroeck and those whose trading activity was more modest were characterized by resources and relationships rather than ability and legal opportunity. Therefore, in theory with favorable circumstances any intelligent seventeenth-century Dutch woman in the United Provinces and America could have achieved the same level

\section{${ }^{7}$ Ibid., 1.}

${ }^{8}$ Dennis Maika, "Commerce and Community: Manhattan Merchants in the Seventeenth-Century," (Ph.D. dissertation, NYU, 1995). Perhaps having met him in Amsterdam, Hardenbroeck married Peter Rudolphus DeVries soon after her arrival in New Netherland (Oct., 10, 1659). Rudolphus died within two years of their marriage. Beimer, Women and Property in Colonial New York, 34. 
of commercial activity that Hardenbroeck did. ${ }^{9}$

Debt litigation and other court records, published journals, and a limited number of published personal correspondence from the late Dutch period and English proprietary period [1664-1673, 1674-1685] of New York history affirm many married women assertively promoted personal and family commercial interests. Male litigants outnumbered female litigants in debt litigation suits in New Netherland and seventeenth-century New York. ${ }^{10}$ Nevertheless, when married women appeared in court to prosecute commercial claims or defend commercial interests, they did so with confidence borne from intimate knowledge of disputed accounts. Even when female defendants in debt litigation suits admitted knowledge of the debts, they sometimes revealed enough knowledge of legal intricacies of commerce to delay judicial decisions. For example, Margaret Hardenbroeck was particularly skilled in delaying judgments against her commercial interests. ${ }^{11}$

In concert with their husbands and independently when husbands could not or chose not to participate, married Dutch women in America aggressively pursued favorable decisions from the courts in debt litigation cases. Assumption of legal

${ }^{9}$ Those circumstances might have included a favorable marriage or perhaps an unexpected financial windfall.

${ }^{10}$ Beimer, Women and Property in Colonial New York, 7. Biemer revealed numbers of female traders and proprietors in New Netherland and seventeenth-century New York from 1654 to 1674 . However, there was little analysis of particularly less affluent women.

${ }^{11}$ Michael E. Gherke, "Margaret Hardenbroeck: New York Merchant," (unpublished paper, First Annual West Virginia University History Forum, 1997), 8. 
responsibilities for finances related to commerce by married Dutch women came about from a variety of historic factors that caused development of a uniquely Dutch perception of marital partnership and the roles women were expected to assume in Dutch society. However, after the English expropriation of New Netherland, wives' assumption of commercial responsibilities as a nonpareil expression of European culture in America was replaced by increasing economic anonymity and financial marginalization of women.

During the first decade of English control of New York, 1664-1673, married Dutch women continued to actively participate in commerce. However, except among elite women like Margaret Hardenbroeck, Maria van Rensselaer, and a few others, after 1674 when England acquired uncontested permanent legal possession of New Netherland, women's participation in commerce began a precipitous decline from which it did not recover until the twentieth-century. ${ }^{12}$ The decline in women's commercial activity after 1674 was one response to the increasing influence of English patriarchic culture in New York communicated through increasing anglicization. Anglicization occurred to promote English commercial policies and the interests of the Duke of York and his provincial appointees, who had their own group of colonial favorites to satisfy. ${ }^{13}$

\footnotetext{
${ }^{12}$ Rosen, "The Economic Marginalization of Women," Courts and Commerce, Part 3: 93-194.

${ }^{13}$ Many authors have analyzed the ascent of a political elite in proprietary New York and their connections with different governors. Among the authors are Ritchie, The Duke's Province and Maika, "Manhattan Merchants in the Seventeenth-Century." Emphasis on anglicization here does not imply there was no "Batavianization," as John Murrin phrased the assimilation of cultures in seventeenth-century New York. That is, initially dominant aspects of English culture were grafted onto the mixture of cultures
} 
Particularly among non elite women, institutional and demographic changes resulting from England's permanent acquisition of New Netherland through the Treaty of Westminster in 1674 brought about reluctance or inability to pursue commercial activities. $^{14}$

Commercial activity by married Dutch women in the seventeenth-century Netherlands and America was a cultural characteristic of the Dutch. Increased expression of commercial activity by women occurred in the commercial orientation of the Netherlands in the early modern period. Owing to the geographic location of the Netherlands between England and the German states, the northern Dutch provinces were particularly well-positioned when commercial activity accelerated in the late Middle Ages. ${ }^{15}$ By the last quarter of the sixteenth-century when the phrase "golden age" came into metaphoric use for the acceleration of Dutch commerce, provinces like Holland were predisposed to commercial capitalism. ${ }^{16}$ For example, by the beginning of the seventeenth-century commercial agriculture was important to the economy of Holland. ${ }^{17}$

and nationalities that comprised the New York population. Murrin, "English Rights as Ethnic Aggression," 66; Goodfriend, Before the Melting Pot, 6.

${ }^{14}$ While the 1664 expropriation brought increased English immigration, many did not stay permanently. Ibid., 52.

${ }^{15}$ K.H.D. Haley, "from Boniface to Erasmus," The British and the Dutch: Political and Cultural Relations Through the Ages (London, 1988), 15-26.

${ }^{16}$ For a historiographic discussion of use of the phrase "golden age," see Els Kloek, "Introduction," Women of the Golden Age, 9-18.

${ }^{17}$ Jan Folkerts, "Kiliaen van Rensselaer and Agricultural Productivity in His Domain: A New Look at the First Patroon and Rensselaerswijck Before 1664," in Zeller, A Beautiful and Fruitful Place, 295-308: 295-296. 
The urban population of Holland promoted local retail trade and geographic orientation to the sea encouraged transoceanic trade with particularly England. ${ }^{18}$ A combination of other factors also influenced women's roles in commerce. A foundation of Roman law, particularly the code of Justinian, traditional male occupations like fishing and longdistance commerce that kept husbands away from home, and rapid acceleration of commerce in the early modern period greatly expanded responsibilities of wives beyond their households and domestic duties.

Throughout the seventeenth century, English male visitors to the United Provinces expressed uneasiness and dismay about the commercial activity of Dutch women. ${ }^{19}$ Seeing Dutch women in roles that in England were most often conducted by males threatened English cultural constructs about patriarchy and the domesticity of women. However, seventeenth-century English male visitors failed to comprehend the relationship between domesticity and commercial activity by women in the Netherlands. The commercial orientation of the Dutch economy expanded boundaries of domesticity

${ }^{18}$ A.M. van der Woude, "Variations in the size and structure of the household in the United Provinces of the Netherlands in the seventeenth and eighteenth centuries," in Peter Laslett, ed. Household and Family in Past Time (Cambridge, 1972), 299-318: 303.

${ }^{19}$ Albert Ivatt, ed. The Memoirs and Travels of Sir John Reresby, Bart., 16341689 (Cambridge, 1904), 137; Fynes Moryson, An Itinerary containing his ten yeares travell, 4 vols. (Glasgow, 1907-1908), 4: 58; William Temple, Observations Upon the United Provinces of the Netherlands, George Clark, ed. (Oxford, 1972), 89. Not all travelers to the Netherlands in the seventeenth-century were male and critical of Dutch women's roles. Antonia Fraser, The Weaker Vessel, 125-127, related the story of Mary Ward, an English Catholic who, in order to freely practice her religion, emigrated to the Netherlands where she established a school, St. Omer, for young English Catholic women. Ward was condemned by men within the English Catholic Church for encouraging formal education for women. 
by giving married women responsibilities for trade in addition to other duties associated with marriage and motherhood. In addition, the influence of Roman law opened legal avenues for expression of these responsibilities. ${ }^{20}$ That was why Jan van Beverwijck could defend Dutch women in 1643 by writing, "many [Dutch] women, without forgetting the house, practice trade and commerce ...."21

An area where domesticity and commerce frequently merged in urban Dutch society was the family dwelling. ${ }^{22}$ Retail trade conducted by married women within areas of their homes specifically designed for that purpose was common in provinces like Holland. Physical barriers guarded private areas from areas open to the public and thereby psychologically guarded the purity of domesticity from the unseemliness of the outside world. Nevertheless, commerce on this scale was conducive to performance of other duties associated with domesticity. ${ }^{23}$ Specifically, as with indoor handicraft textile production, local retail trade conducted in private homes enabled wives to perform gender related responsibilities identified with marriage and motherhood. ${ }^{24}$

In ways similar to seventeenth-century English male writers, some male Dutch

${ }^{20}$ Grotius, Jurisprudence of Holland, 11.

${ }^{21}$ Van Beverwijck, Van de Uitnementhyt Geslachts, 211.

${ }^{22}$ Mertine Segalen, "The House Between Private and Public: A Socio-historical Overview," in van Schuurman, Private Domain, Public Inquiry, 240-253: passim.

${ }^{23}$ Schama, The Embarrassment of Riches, 375-397: 391. Schama's work emphasized the cultural contradictions of the early modern Dutch, of which women's participation in commerce in a patriarchal society was one expression.

${ }^{24} \mathrm{Haley}$, The British and the Dutch, 19; Irwin, Anna Maria van Schurman, xiv; Schama, The Embarrassment of Riches, 391. 
writers expressed discomfort with proliferation of commercial activity by women in the Netherlands. Writers like the frequently didactic Jacob Cats, some of whose writings are interpreted as avant-guarde early feminism, expressed dogmatic ideas regarding the roles of women. ${ }^{25}$ Writing in Huwelijk [Marriage], Cats related,

"De man moet op de straat om zinjin handel gaan; Het wiif moet in de huis de kucken gadesloon. Het vlitig straatwoel wordt in de man geprezen; Maar in een tere vrouw een stil en zedig wesen. Gij, reist dam maarstig man, en past op uw gezin. Gij, zet $u$, O jonge vrouw, en let op uw gezin." ${ }^{26}$

trans.

"The husband must be on the street to practice his trade; the wife must stay at home to be in the kitchen. The diligent practice of street wisdom in man be praised. But with the delicate wife, there should be quiet and steady ways. So you, industrious husband, go to earn your living. While you, O young wife, attend to your household." 27

Despite the difficulties of translation, little of Cats' intent is lost. Cats'

prescription for the commercial activity of wives and husbands reflects the early modern

${ }^{25}$ The assertion Cats promoted sexual equality is based on interpretations of Wereldts begin, midden, eynde, besloten in de Trouringh [The Beginning, Middle, and End of the World Enclosed in a Wedding Ring] (Dordrecht, 1637), by authors like Arie van Deursen, "Jacob Cats and the married woman, A response to Agnes Sneller," in Kloek, Women of the Golden Age, 35-38: 38. Through what she labels, "assertive," i.e., deconstructive, reading of de Trouringh, Sneller, "Reading Jacob Cats," ibid., 21-34, asserts subtle reading of Cats' work shows sexist thought consistent with his time.

${ }^{26}$ Cats, Huwelijk, A. Agnes Sneller, ed. (Hilversum, 1993), 72.

${ }^{27}$ Schama, The Embarrassment of Riches, 400. 
Dutch attraction to classical and biblically based cultural orthodoxy. Divinely ordained, historically supported social order based on gender psychologically comforted the Dutch, as it did most Europeans. ${ }^{28}$ The didacticism of Cats was clear; the commercial functions of Dutch husbands were public and self-directed while those of their wives were domestic and determined by the needs and desires of their families. Therefore, many in seventeenth-century Dutch society were more comfortable with women's participation in commerce when it was viewed as an amplification of domesticity.

Establishing a relationship between domesticity and the commercial activity of women provides an intellectually satisfying patriarchal explanation for the unconventional roles performed by Dutch women in the early modern period. However, the relationship is inadequate to explain the intellectual independence of unmarried women like Anna Maria van Schuurman, and the financial independence of women like Margaret Hardenbroeck. ${ }^{29}$ Commercial participation as an expression of domesticity combined with powerful intellectual, religious, and economic events in the early modern Netherlands to create an environment that encouraged expansion of women's responsibilities. That environment encouraged an expansion of women's responsibilities and opened avenues of self-expression for them. Through expansion of the parameters of domesticity, women began to achieve recognition for activities unrelated to domesticity.

In the Netherlands, the Renaissance, Reformation and commercial revolution

\footnotetext{
${ }^{28}$ Irwin, Anna Maria van Schurman, 3.

${ }^{29}$ Van Schuurman was one of the most learned women in early modern Europe.
} 
combined to provide a fertile environment for the political struggle for independence from Spain. These movements also worked together to transform the culture of the seven northern Dutch provinces that became the United Provinces of the Netherlands. In combination with domestic training and opportunities for formal education, these powerful movements also increased opportunities for self-expression by women in the Netherlands that were uncommon to all but elite women in most European cultures. Specifically, humanism and Calvinism redefined Dutch culture by questioning fundamental relationships. However, the Dutch did not experience a reformation in patriarchy and an end to misogyny through the influences of Erasmus, Spinosa, and Calvinist Protestantism. Nevertheless, the individualism inherent in humanism and Calvinist Protestantism emphasized the positive attributes of self-expression over dogmatic dictates of convention. ${ }^{30}$ The religious and economic climate in the Netherlands in the sixteenth and seventeenth centuries stimulated political and commercial revolutions. ${ }^{31}$ In combination with expressions of humanism and Calvinist Protestantism, the commercial and political revolutions created unusual responsibilities and opportunities for women.

However, the United Provinces of the Netherlands was not an anomalous early

\footnotetext{
${ }^{30}$ For example, while the Dutch Reformed Church was the only officially sanctioned church in the United Provinces, membership was voluntary and other Christian sects, including Catholicism, and other religions like Judaism, were tolerated if not necessarily enthusiastically embraced. Van Deursen, Plain Lives in a Golden Age, 266.

${ }^{31}$ The political, religious, and commercial revolutions in the Netherlands have been extensively researched in the works of many authors. They are included in the bibliography.
} 
example of a lost opportunity for social and economic equality for women. While intellectuals like Anna Maria van Schuurman, a woman highly respected for her scholarship, were advocates of increased opportunities for women, their advocacy was firmly connected to the conventions of their culture and age. In deference to biblically based, traditional dogma that asserted the primacy of domesticity for women, van Schuurman's writing reflected the social and religious standards of early modern Europe. In a tract she wrote to theologian, André Rivet, in which she developed a syllogistic argument in support of formal education for women, van Schuurman wrote,

"The goal of studies [for women] is presumed to not be vainglory and show or idle curiosity, but rather the general goal of the glory of God and the salvation of one's soul in order that she may also emerge the better and happier and may educate and guide her family (if that duty fall to her) and even be useful to her whole sex, to the extent that that is possible." ${ }^{32}$

It was difficult for Rivet and other learned men with whom van Schuurman corresponded to refute the practical logic used by van Schuurman that so neatly combined domesticity, Christian salvation and proselytization, and patriotism. Nevertheless, as van Schuurman recognized about herself, men like Rivet believed she was a singular force with limited opportunities for changing the status of women. ${ }^{33}$ Commercial capitalism in the early modern Netherlands proved a more powerful

\footnotetext{
${ }^{32}$ Van Schuurman, Whether the study of letters is fitting for a Christian woman," A Practical Problem: For the venerable and distinguished theologian, Mr. André Rivet; Irwin, Anna Maria van Schurman, 26. Italics are mine.

33““André Rivet to Anna Maria van Schuurman, March 18, 1638,” Ibid., 48-54.
} 
motivator for expanding roles for Dutch women than the intellectual sophism of van Schuurman.

Humanism and Calvinism contributed intellectual and religious foundations for proliferation of commercial activity by married Dutch women. However, no factor was as important as the rapid acceleration of commercial capitalism that was tied to the political struggle for independence from Spain. Discussing husbands' legal liabilities resulting from commercial activity by their wives, jurist Hugo Grotius explained how the golden age of Dutch commerce advanced wives' power to make contracts. He wrote,

"in time of old, a husband whose wife was want to bake or brew, might lose by her an oven-ful of bread or a brew of beer, without the husband being able to do anything against it; likewise, if a man's wife was want to sell or buy woollen yarn or linen, he might lose by her a stone-weight: even if the wife did not carry on public trade, her husband might suffer to the extent of four pennies. This existing, but later, the commerce and wealth of the country being greatly increased, the principle was extended, so that to-day a married woman, engaged in public commerce or trade, may contract in all matters relating thereto, and consequently may bind herself and her husband ... "34

Although civil litigation caused by the legal ability of wives to make contracts occurred between spouses, the above passage expressed the basis of Dutch marital partnership rather than polarity in gender roles. The legal capacity of married women to make contracts, represent themselves and their families in court, and otherwise legally bind themselves and their husbands, was a significant indication of Dutch society's

\footnotetext{
${ }^{34}$ Grotius, Jurisprudence of Holland, 31.
} 
dependence on women to act responsibly for the benefit of their families, and through them, for the benefit of their country. With little variation, this characteristic of Dutch marriage and the roles of women in the United Provinéces was abundantly expressed by the Dutch communities of seventeenth-century America.

Inasmuch as New Netherland was a creation of seventeenth-century Dutch capitalism, records from the colony reflect intense commercial activity by women. ${ }^{35}$ However, historians have traditionally had difficulty interpreting the commercial activity of Dutch women in early America without using the boundaries imposed by seventeenth-century English cultural constructss regarding women. Specifically, there is conceptual contradiction that makes reconciliation between Dutch women's domesticity and expressions of their participation in commerce difficult. Therefore, there is a recidivist tendency to retreat to comfortable models associated with English culture in early America. In order to resolve the paradox, historians interpret the commercial activities of married women in New Netherland as an extension of their husbands' business affairs. ${ }^{36}$ By implication, seventeenth-century Dutch wives in America are unintentionally cast in the role of deputy-husband in the model established by Laurel Thatcher Ulrich alluded to in chapter two. ${ }^{37} \mathrm{I}$ believe this is a misrepresentation of marital partnership among the seventeenth-century Dutch. While

\footnotetext{
${ }^{35}$ Biemer, "Criminal Law and Women in New Amsterdam and Early New York," in Zeller, ed. A Beautiful and Fruitful Place, 73-82: 74.

${ }^{36}$ Morris, "Women's Rights in Early American Law," Studies in the History of American Law, chapter 3: 126-200; Shattuck, "A Civil Society," 156.

${ }^{37}$ Ulrich, Good Wives, 35-50.
} 
married Dutch women legally acted in place of their husbands, particularly in commerce, they were not exclusively adjuncts to their husbands. Inferring commercial activity by Dutch wives in early America was secondary to their husbands' promotes a particularly English expression of gender roles in marriage. The implications are wives acted with little independent thought. Nevertheless, difficulties of interpretation arise from contradictory expressions inherent in Dutch patriarchy.

Manifestations of seventeenth-century Dutch cultural standards were ostensibly inconsistent. Authors like Simon Schama, Arie van Deursen, and others continue to try to resolve the contradictions by debating interpretations of dynamic forces that influenced early modern Dutch perceptions of women's roles. ${ }^{38}$ With abundant use of iconography, Simon Schama reached into the psyche of the seventeenth-century Dutch elite to explain the contradictions between domesticity and the uncommon responsibilities and opportunities conferred on married women. Relying more on literary records than symbolism, van Deursen's subjects were commoners. ${ }^{39}$ However, both historians arrived at similar conclusions about seventeenth-century Dutch women. They recognized the uniqueness of women's roles in Dutch society as a product of an extraordinary age, the potential for excess of which was restrained by the forces of religious and social conventions.

\footnotetext{
${ }^{38}$ Schama, The Embarrassment of Riches; van Deursen, Plain Lives in a Golden Age; "Jacob Cats and the married woman," 35-38; Lia van Gemert, "The Power of the weaker vessel: Simon Schama and Johan van Beveriwjck on women," 39-50; Marijke Spies, "Not every contradiciton is a contradiction: A response to Lia van Gemert," 5153, Kloek, Women of the Golden age.

${ }^{39}$ Van Deursen, Plain Lives in a Golden Age, preface.
} 
Regardless of the ability of some Dutch women to use the uncommon opportunities available to them in the early modern period to acquire different expressions of independence, marriage remained the primary agency of material support for most. ${ }^{40}$ However, marriage and the family connections created by marriage were interdependent and once created were usually insoluble. ${ }^{41}$ In that context, independent commercial activity by married Dutch women in Europe and America was an important function of family responsibility in ways similar to that of Dutch men. That is, wives and husbands shared responsibilities for the material support of their families.

Commercial activity by women in New Netherland and seventeenth-century New York was intricately woven into the fabric of the colonial economy. While the division is arbitrary, separating levels of commercial activity between affluent and lessaffluent women provides an instrument for exploring ways their activities were connected to each other and the colonial and transoceanic economies. Women like Margaret Hardenbroeck, Maria van Rensselaer, and others came from financially powerful families and their commercial decisions often affected people with direct and indirect financial links to the families. The commercial activities of most women were performed to advance the financial interests of their immediate families and their individual decisions rarely affected large numbers of people. Notwithstanding the limited influence of their individual economic decisions, in aggregate the commercial

\footnotetext{
${ }^{40}$ Van Deursen, "Jacob Cats and the married woman," 37.

${ }^{41}$ Ibid.; Christoph, "The Colonial Family," in Zeller, A Beautiful and Fruitful Place, 111-118; Alice M. Kenney, The Gansevorts of Albany: Dutch Patricians in the Upper Hudson Valley (Syracuse, 1969).
} 
decisions of less-affluent women helped define the broader economic environment of the colony.

Magdalena Joire was the wife of Mattheu Blansjan, a Wildwijck (Kingston) farmer, and the mother of three minor children when her husband recorded their will in July $1665 .{ }^{42}$ She was skilled at knitting which she used to help support her family by selling items of knitted apparel and providing knitting instruction to the young women of Wildwijck. Providing woolens was an important activity in New Netherland prior to increased English immigration into the colony after England assumed political authority. ${ }^{43}$ In 1655 , Adriaen van der Donck indicated wool production was not as important in New Netherland as it was in New England, "where the weaving business is driven. ${ }^{44}$ By 1670, Daniel Denton reported the New York population was nearly selfsufficient in wool production. ${ }^{45}$

One of the significant inferences about Joire's commercial knitting production and service activities was her recognition of a market for her skill. In his 1995 dissertation, Dennis Maika reflected on the ability of elite, predominantly Dutch,

42،Will of Mattheu Blansjan,” Kingston Papers, 2: 575-576.

${ }^{43}$ Percy Wells Bidwell and John I. Falconer, History of Agriculture in the Northern United States, 1620-1860 (Washington, D.C., 1925), 26-32, found twenty-one percent of Dutch farms and 43 percent of English farms on Long Island had sheep in 1675 .

${ }^{44}$ Van der Donck, A Description of New Netherlands, 42.

${ }^{45}$ Daniel Denton, A Brief Description of New York: Formerly Called NewNetherlands With Places thereunto Adjoining (London, 1670; rpt. Richmond VA., 1973), 82. 
Manhattan merchants to aggressively pursue and prevail in their commercial endeavors despite existence of, but often with the cooperation of, English colonial administrators. ${ }^{46}$ Joire's activities and those of other non-elite women who supplied local markets were small in comparison to the major merchants and merchant-traders described by Maika, but indicate the purposeful pursuit of commerce was not limited by sex or status. Jorie appeared in court as a plaintiff when those who accumulated debts to her for knitting and knitting instruction failed to make payment or denied the amount she charged. ${ }^{47}$ Interestingly, Mattheu Blansjan, her husband, frequently appeared in court for a variety of suits and prosecutions, but he never appeared with or for his wife in suits related to her knitting. ${ }^{48}$

Consistent with the activities of Jorie, many New Netherland and seventeenthcentury New York wives turned domestic skills into commercial enterprises. Their efforts often required knowledge of markets and clientele and familiarity with regulations and concerns of public officials. In November 1656, Neeltie Wessels applied for permission from the Court of Burgomasters and Schepens of New Amsterdam to open a tavern for customers who consumed her cooking, wine, and beer. ${ }^{49}$ The primary concern of the magistrates was Wessels' ability to control the behavior of her customers when their drinking became excessive. Wessels neither

\footnotetext{
${ }^{46}$ Maika, "Commerce and Community," 129-156.

${ }^{47}$ Kingston Papers, 2: 426, 431, 432, 433.

${ }^{48}$ Ibid., 1: passim.

${ }^{49} R N A, 2: 233$.
} 
volunteered nor was she required to indicate how she would maintain order, but she was granted permission to open her establishment anyway, "on condition that she observe order as is proper therein." ${ }^{, 50}$ Conditional permission by the Court was pro forma, but indicated Wessels was not favored or denied consent owing to her sex. Further, we can infer from her request she was confident in her ability to manage the enterprise successfully.

The inference is based on the premise that Wessels, like other male and female retailers, was required to have or make a variety of commercial connections necessary for successful operation of her business. Specifically, she needed to know the people who would supply her with the food, wine, and beer she intended to prepare for sale, their reliability, how much they could supply and how often, and how much they were likely to charge. In addition, she was an entrepreneur in a debit-credit economy and the nature of her enterprise demanded establishment of credit and a reputation for repaying her debts.

The application of permission to operate a retail establishment that served food and alcoholic drinks further indicated Wessels' connections with the larger economy of New Netherland, including transoceanic commerce. First, Wessels and the producers who supplied her required a sympathetic and even proactive government willing to pass and enforce regulations conducive to trade. Among the duties of government was to regulate behavior and enforce civil contracts. For example, failure to report the methods she intended to use to maintain order in her tavern may indicate Wessels was required to

\footnotetext{
${ }^{50}$ Ibid.
} 
give a bond in the event intervention by the schout became necessary. In addition, government regulations helped maintain Wessels' business relationships with her producers and customers. That is, disputes over payments required adjudication based on established rules of law. Nevertheless, public officials in New Netherland went further by creating a regulatory environment similar to the Netherlands in which commerce was promoted.

Wessels' decision to open a retail business that served food was indirectly influenced by a 1656 New Amsterdam ordinance for creation of a market day. Establishment of a market day was consistent with local trade in the Netherlands and an example of the intense regulation of commerce in New Netherland. ${ }^{51}$ Creating market days was necessary in the early modern period to enable local buyers and sellers to come together to make their exchanges. The 1656 ordinance in New Amsterdam was established after market farmers complained to the magistrates their produce frequently lay rotting on the docks owing to lack of coordination with the local populace. ${ }^{52}$ New Netherland survived on agriculture, but prospered through commerce. Like seventeenth-century Holland, New Netherland practiced commercial agriculture and it

\footnotetext{
${ }^{51}$ For example, market days were incorporated into the legal system. Grotius, Jurisprudence of Holland, 27, maintained banns for marriage were required, "on three Sundays or market-days"; for the intense regulation of trade in Manhattan specifically and New Netherland in general see, Maika, "For Love of 'Orderly Behavior': Local Commercial Regulation, 1653-1674," "Commerce and Community," chapter 5: 279321.

${ }^{52} R N A, 1: 23$.
} 
was a negligent farmer who inadequately prepared his fields for production. ${ }^{53}$ Kitchen gardens were important for daily maintenance of families, but market gardens enabled merchants like Neeltie Wessels to conduct trade by providing her with the products she required for conducting business. From the creation of a market day, assuring weights and measures of imported goods like wine, and forming rules for debt litigation through use of established laws, government regulation was necessary for women and men to operate their local retail enterprises successfully. Commercial relationships that were established by town-dwelling businesswomen also enabled them to devote more time to management of their enterprises. They were freed from some of the burdens of production for their families because they were supplied with those items by the producers who contracted with their businesses. For example, time consuming activities like dairy production and beer brewing may not have been part of their weekly routine as it was for many other women. ${ }^{54}$

The web of commercial relationships required for successful retailing by Neeltie Wessels and other businesswomen was indicative of the significance and complexity of women's contributions to the colonial economy. Wessels was also commercially connected to farm women who, with their husbands, provided the labor that created the products she sold at retail in her establishment. Farm wives did not necessarily labor in gender specific tasks in isolation from the work of their husbands, but some duties were

${ }^{53}$ Van Deursen, Plain Lives in a Golden Age, 14-15; Folkerts, "Kiliaen van Rensselaer and Agricultural Productivity," 299-300.

${ }^{54}$ McMahon, "Gender, Dietary Decisions, and Food Preservation," 165; Cowen, More Work for Mother, 25. 
more conducive to the responsibilities of motherhood. Among the agricultural products like meat, bacon, and turnips listed in the market-farmer's petition for a market day were butter and cheese. ${ }^{55}$ It is unlikely seventeenth-century New Netherland and New York farm women produced dairy products exclusively for market, but selling surpluses gave women opportunities to contribute to the maintenance of their families by providing extra income. Moreover, using elementary economic analysis, an experienced farm wife could roughly calculate how much of her production was likely to be surplus. ${ }^{56}$ Material goods often passed from one generation or family in New Netherland and seventeenth-century New York to another. Surplus agricultural production enabled farm families to maintain machinery that, owing to the marketability of surpluses, may be considered capital goods. Tools like churns for butter-making and presses for cheese-making were probably made locally by coopers like Jan Harmensen of New Amsterdam. ${ }^{57}$ The tools are indicative of commercial relationships between surplus domestic production by women and local specialized crafts manufacturing. However, a few capital tools could not be made locally. For example, beer brewing was also performed by wives for family consumption and the market and required specialized knowledge and tools. ${ }^{58}$ At least some of the materials necessary for brewing

${ }^{55} R N A, 1: 23$.

${ }^{56}$ Joan M. Jensen, Loosening the Bonds: Mid-Atlantic Farm Women, 1750-1850 (New Haven, CT., and London, 1986), 87.

${ }^{57} R N A, 5: 332$.

${ }^{58}$ Ulrich, Good Wives, 23. 
beer were initially brought over from the Netherlands or imported from other areas. Owing to the volume of consumption of beer in New Netherland and seventeenthcentury New York, machinery for brewing was valuable. An inventory of brewery items sold by Rynier van der Coele[n] to Thoomas Harmensen was representative of others recorded in sale and legacy inventories. Among the tools necessary for brewing beer, the Coelen brewery included, "a brew-kettle and tubs, malt kiln ... distilling kettle, hose, (and) head [cover] of the still and tubs. ${ }^{, 59}$

As highly saleable commodities, beer and distilled liquors were not the exclusive manufacture of farm women. However, the level of demand in the colony increased opportunities for women to improve the financial conditions of their families through brewing. When, in April 1665, Maria van Rensselaer was suffering from the combined conditions of advanced pregnancy and chronic debilitating illness, her husband, Jeremias van Rensselaer, assumed management of the family brewery located across the Hudson river (east side) from their Rensselaerswijck home. ${ }^{60}$ Van Rensselaer indicated he had, "taken up brewing, and this for the sake of my wife, as in her father's house she always had the management thereof, to wit, the disposal of the beer and helping to find customers for it." ${ }^{\prime 61}$

${ }^{59}$ Kingston Papers, 2: 681. Tools like these were necessary for brewing beer in significant quantities and are mentioned in enough inventories of brewers to consider them essential.

${ }^{60}$ Christoph, "Worthy, Virtuous Juffrow," 26-28. I refer to Maria's illness on page 40 .

${ }^{61}$ CJVR, 377-378. 
Jeremias van Rensselaer's commentary about his wife's pre-marriage commercial activity is instructive owing to the sparsity of records about the training of young women for commercial activity. Particularly court records of litigation reveals post facto evidence of women's training in commerce, but only a few records show how they were trained. Jeremias van Rensselaer's comment about his wife's management of her father's brewery indicates their training was experiential. Nevertheless, generalizations based on the experiences of one young woman and particularly an elite woman, are cautionary. Fortunately, the van Rensselaer correspondence reveals how another young woman from considerably more humble circumstances was trained.

Talckien [Taltie, Talletje, Talletien], who was not further identified in the van Rensselaer correspondence, was the maidservant of Anna van Rensselaer, the family matriarch. Owing to self-initiative or the encouragement of van Rensselaer family members, Talckien began to send items of trade to New Netherland with the bulk materials sent by the van Rensselaers. The amount and value of the goods she attempted to trade were small compared with the trade of the van Rensselaers. Regardless, owing to her meager resources Talckien's participation in transoceanic commerce on this limited scale represented a significant investment for her. In December 1656, Anna van Rensselaer wrote to Jeremias, "Talckien send herewith, from the little she has and out of what she has now and then scraped together and saved out of her mouth, in a small box, marked [illegible], six silver spoons, which cost 30 florins, and also a pair of silk stockings, of 10 florins. Do your best to send shortly something 
in return for them ... “62

As a servant in the van Rensselaer household, Talckien must have been privy to family discussions and activities related to commerce. More specifically, close proximity to her direct employer, Anna van Rensselaer, allowed Talckien to witness the activities of a decisive and powerful woman involved in the intricacies of transoceanic commerce. After a few tentative trading efforts, Talckien apparently felt confident enough to take greater risks. She was encouraged in her trading efforts by Nicolaes van Rensselaer, younger brother of Jan Baptist and Jeremias. In addition, she could make use of the van Rensselaer trading network and Jeremias' action as factor. Under those conditions she borrowed money at interest to invest in trade. Jan Baptist, who was at home in the Netherlands, expressed concern about her investment and was mildly critical of Nicolaes for encouraging the girl to take the risk. He wrote to Jeremias, "The goods sent to you by brother Nicolaes belong to [our] servant girl. Please see to it she get her return at the first opportunity. The rascal [dien bengal] (Nicolaes) has made the maid believe a good deal, so that she has borrowed some money for that purpose on which interest must be paid." ${ }^{63}$ Notwithstanding its small amount, the van Rensselaers were not willing to subsidize Talckien's investments. Nevertheless, they took measures to help her achieve a profit, which indicates something about ways young women were 36.

62،Anna van Rensselaer to Jeremias van Rensselaer, December 5, 1656," Ibid.,

63، Jan Baptist van Rensselaer to Jeremias van Rensselaer, December 5, 1656," Ibid., 201. Dien Bengal, which is how Jan Baptist referred to Nicolaes for encouraging Talckien, is translated in modern Dutch, "naughty boy," which may indicate lighthearted condemnation. 
trained in commerce.

Other than being employed by the van Rensselaers and her limited efforts in transoceanic commerce, nothing is known about Talckien. ${ }^{64}$ However, based on the small amount of items she offered for trade and the circumstances of other young women hired out as servants to wealthier neighbors in the Netherlands, it is likely she was born to a family with modest means. ${ }^{65}$ The experiences of some maidservants was, in balance, very negative. Their lot was characterized by ill-treatment and strained relations with their employers. ${ }^{66}$ The relationship between Talckien and the van Rensselaers contradicts that characterization.

Specifically, Talckien's encouragement from the van Rensselaers and use of their trading network with New Netherland implies a familial relationship. In regard to her trading efforts she was treated no differently than family members also learning the rudiments of commerce. Anna and Jeremias van Rensselaer corresponded about the trading activities of the van Rensselaer daughters, Hillegonda and [E]leonora, in terms similar to those used in correspondence about Talckien. Writing in December 1656,

\footnotetext{
${ }^{64}$ Particularly important may have been her age. For example, few maidservants in Rotterdam in the eighteenth-century were under twenty years old and many made the occupation a life time career. See, Marybeth Carlson, "A A Trojan horse of worldliness?' Maidservants in the burgher household in Rotterdam at the end of the seventeenth century," in Kloek, Women of the Golden Age, 87-95:93.

${ }^{65}$ Ibid.; Rudolf Dekker, "Children on their Own, Changing Relations in the Family: the Experiences of Dutch Autobiographers, Seventeenth to Nineteenth Centuries," in van Schuurman and Spierenburg, Private Domain, Public Inquiry, 61-71: 64.

$$
{ }^{66} \text { Carlson, “"A Trojan Horse of Worldliness?”, 89-90. }
$$
}


Anna van Rensselaer indicated,

"The fine gold and silver bands (hat bands) I have not sent either, for I am sending now 4 fine hat bands, such as I trust you mean. They are for account of your sister Leonora and you must trade them for her and send her the return goods . . . as also those for the 2 pistols which you took with you for her on your last voyage. She thinks that you have had them now long enough to have goods in exchange for them, in which she is right." 67

Similar information about Hillegonda's trading efforts were included in other correspondence, but her premature death in 1656 abruptly ended her participation. ${ }^{68}$

The van Rensselaer correspondence offers only glimpses into ways young women were introduced to trade. Nevertheless, they show young women were expected to learn the ways of commerce through experience. The older van Rensselaers were solicitous about the trading efforts of the young women in their household to the point of patronization. By nurturing their tentative efforts, Anna van Rensselaer and her sons introduced the young women to the intricacies of trade without allowing them to become overwhelmed. Specifically, their patronization was intended to ensure success and whet their appetites for trade. This method of training allowed for increasing amounts and complexities of commercial activity over time and, assuming success, was self-perpetuating. However, training young Dutch women for the responsibilities of commercial participation likely would not have occurred without commensurate legal

${ }^{67}$ Anna van Rensselaer to Jeremias van Rensselaer, December 18, 1656," CJVR, 38.

${ }^{68}$ Ibid. Jeremias was notified of her death on December 5, 1656. 
obligations.

Law and more importantly, its application, is a measure of the expression of the collective social will. ${ }^{69}$ Historians have explored the complexities of Dutch law that enabled married Dutch women in America to perform commercial responsibilities.

Further, they have provided examples of women who appeared in court to prosecute and defend legal claims to the proceeds from implied and written commercial contracts. ${ }^{70}$ However, no one has commented on the assertiveness with which Dutch women in America defended those claims. A survey of women's participation in fifty-nine debt litigation cases from the records of four courts in New Netherland and seventeenthcentury New York for a seventeen year period from 1654 to 1671 reveals consistencies in ways women acted to defend and promote individual and family commercial interests. $^{71}$

\section{Debt Litigation Cases Involving Women}

${ }^{69}$ Edwin W. Patterson, Jurisprudence: Men and Ideas of the Law, 411-412. Law as an expression of social will was part of the German school of jurisprudence developed in the nineteenth-century jurist, Friedrich Karl von Savigny, who wrote about the history of Roman law in the Middle Ages and served as professor of Roman law at the University of Berlin. Ibid., 410.

${ }^{70}$ Biemer, "Seventeenth-Century Law in New Netherland-New York," Women and Property in Colonial New York, chapter one: 1-9; Shattuck, "A Civil Society," 140142, 153-156; Morris, "Women's Rights in Early American Law," Studies in the History of American Law, chapter three.

${ }^{71}$ Commercial transactions beyond regular family financial management was determined by investigation of the details of each case. The courts and numbers of records from each were as follows: forty-three from "Minutes of the Burgomasters and Schepens of New Amsterdam," RNA; 7 from Kingston Papers, NYHM; five from the Orphanmaster's Court of New Amsterdam, and; 4 from the Court of Fort Orange and Beverwijck. 


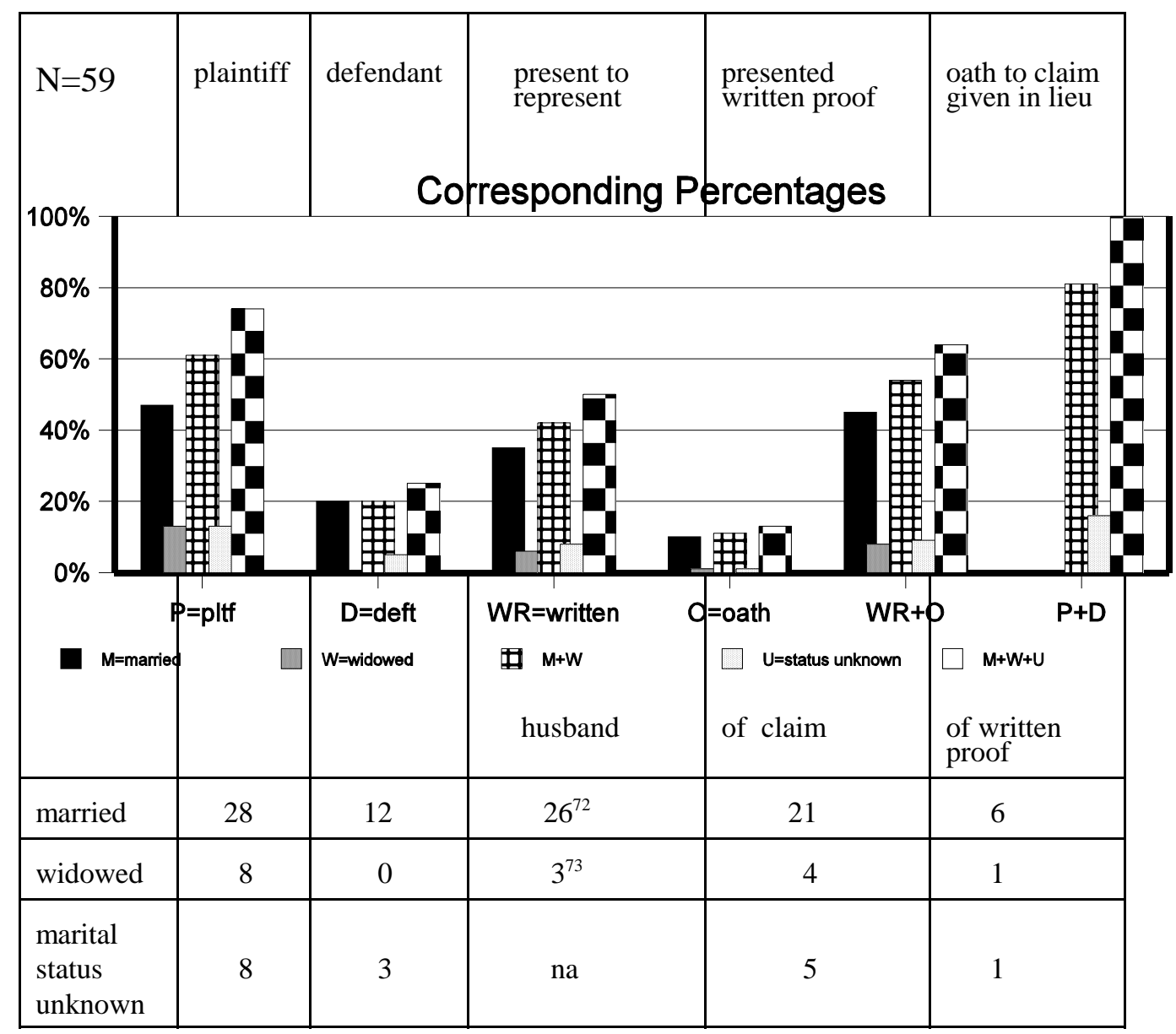

${ }^{72}$ In one case, Sarah Pietersen versus Dirck de Noorman, Pietersen was represented by her husband, Willem Koeck.

${ }^{73}$ These were cases of widows who sued to procure judgements for commercial transactions initiated by their husbands. 
As the table and chart above indicate, whether they initiated suit or were defending their interests, female litigants offered written proof of their claims in 51 percent of the cases. However, when oaths were given, which had the same legal effect as written proof, the percentage increases to 64 percent. Furthermore, 81 percent of the women were married or widowed. In addition, in a substantial majority of the cases women were the plaintiffs rather than defendants. These figures indicate particularly married women's confidence in the validity of their claims and their ability to formally prosecute or defend those claims. More importantly, they reveal women had knowledge of the importance of keeping accurate records. In total, nearly two-thirds of the female litigants in the survey were aware of the requirement of formal proof and used that knowledge to their advantage, indicating they were competent and confident in performing commercial duties.

Frequently, litigation was over small amounts or ostensibly insignificant items, as when retail merchant, Mrs. Anthonie sued cooper Jan Harmensen over a butter churn she claimed was defective and unmerchantable. ${ }^{74}$ However, the amount or relative significance of the item was not as important as the legal and social principles involved. The economy of New Netherland and seventeenth-century New York was not consumer based, yet it does not fit the communal colonial social relationships popular in early

\footnotetext{
${ }^{74} R N A, 6: 304$.
} 
American historiography. ${ }^{75}$ Further, people in New Netherland and New York were litigious in commercial relationships decades before increases in quantities of consumer goods. That is, increased consumption was not prerequisite to establishment of businesslike relationships. ${ }^{76}$ In a colony with a small population accustomed to living spatially near each other in close-knit communities, litigants often knew each other well. ${ }^{77}$ In reliance on mediation and arbitration rather than juries for civil litigation, Dutch legal procedure appears informal to modern jurists. However, application of Dutch jurisprudence was not arbitrary. In a seventeenth-century colonial society with a high level of literacy, strict adherence to legal procedure and written instruments of proof characterized jurisprudence in New Netherland. ${ }^{78}$ Litigants who brought suit had

${ }^{75}$ Christopher Clark, Roots of Rural Capitalism: Western Massachusetts, 17801860 (Ithaca, N.Y., 1990); "Household Economy, Market Exchange and the Rise of Capitalism in the Connecticut Valley, 1800-1860," Journal of Social History 13 (1979), 169-1889; Allan Kulikoff, The Agrarian Origins of American Capitalism (Charlottesville, VA., 1992); James Henretta, "Families and Farms: Mentalitié in PreIndustrial America," $W M Q, 3^{\text {rd }}$ ser. (1978), 3-32; "The Transition to Capitalism in America," in James A. Henretta, Michael Kammen, and Stanley N. Katz, eds. The Transformation of Early American History: Society, Authority, and Ideology (New York, 1991), 218-238.

${ }^{76}$ Rosen, Courts and Commerce, 6.

${ }^{77}$ Donna Merwick, Possessing Albany, 1630-1710: The Dutch and English Experiences (Cambridge, 1990), 106; "Dutch Townsmen and Land Use: A Spatial Perspective on Seventeenth Century Albany, New York," WMQ, $3^{\text {rd }}$ ser. (January, 1980), 53-78: 60.

${ }^{78}$ Shattuck, "A Civil Society," 55-61. Among the indications are frequency of signatures on legal documents, frequent reference to account books in civil litigation, schoolmasters' applications to open schools, and existence of a seventeenth-century colonial newspaper, the New Netherland Mercury. There are no extant copies of the newspaper, but reference to it is found in CJVR, 329, 332. 
to be confident of the accuracy of their claims and their ability to prove them or prepared for court costs and the possibility of counter suits.

Therefore, legal procedure was an important agency for expression of commercial responsibilities and opportunities by women. The sample of fifty-nine debt litigation records involving women indicates women were particularly adept at using the mechanisms of law to achieve success in their litigation efforts.

The accompanying table and chart below shows female litigants were successful in nearly sixty-two percent of the cases regardless of whether they were plaintiffs or defendants. Combined with cases about which the outcome went unrecorded owing to submission to arbitration or ordered private reconciliation the percentage advances to sixty-four. More importantly, rulings against women were slightly less than seventeen percent of the total.

Outcome of Court Decisions Involving Women

\begin{tabular}{|c|c|c|l|l|}
\hline $\begin{array}{c}\text { for } \\
\text { woman }\end{array}$ & against woman & sent to arbiters & $\begin{array}{l}\text { ordered to } \\
\text { make private } \\
\text { settlement }\end{array}$ & $\begin{array}{l}\text { postponed } \\
\text { with no } \\
\text { further result }\end{array}$ \\
\hline 36 & 10 & 6 & 6 & 1 \\
\hline
\end{tabular}




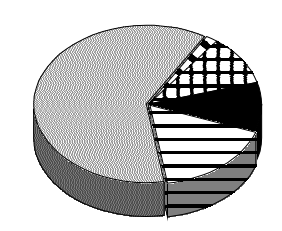

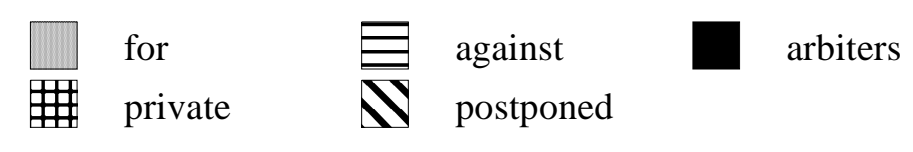

These percentages show an uncommon level of legal competence among Dutch women in America, which is consistent with a tradition of commercial activity by Dutch women in Europe. Law was the primary means through which women protected and expressed their commercial efforts. Significantly, eight female defendants in the sample won their cases. ${ }^{79}$ These eight are important owing to their ability to defend commercial transactions with written records or affirmation by oath. That is, they managed commercial transactions with enough knowledge to convince the magistrates of the accuracy of their accounts. Women plaintiffs were more successful, but unlike defendants, were the challengers and could make sure of the accuracy of their accounts prior to litigation.

Another conspicuous relationship established from the survey is commercial activity and marriage. As indicated previously, eighty-one percent of the women

\footnotetext{
${ }^{79}$ In one case the plaintiff and defendant were both women, March 2, 1665, Marytje Jellis versus Cataryna de Sille. RNA, 5: 194.
} 
surveyed were married or had been married. That data indicates women considered commercial activity a duty of marriage. Nevertheless, there was something more than duty involved. While more open to expanded roles for women than many cultures, seventeenth-century Dutch patriarchy in Europe and America was not tolerant enough to allow women political and religious expression in ways similar to men. That is, traditional formal positions of power in church and government were the prerogative of males. Women could and did express themselves informally and some, like Anna Maria van Schuurman, were able to express themselves formally in writing in these arenas. Regardless, owing to patriarchal convention women were denied liturgical participation. Van Schuurman eschewed her literary pursuits in favor of following Jean de Labadie, the one-time Jesuit turned Protestant reformer. While she defended the religious doctrines of Labadie in works like her autobiographical apologia, Eukleria, and even lived in his house in Amsterdam for a brief period, had she desired to become an advocate in the pulpit, she would have been denied the opportunity. ${ }^{80}$ Given her devotion to Labadie and his doctrines and her prodigious talents, it is informative about her and her culture that she did not attempt to do more than write about her convictions. ${ }^{81}$

Legal and social acceptance of commercial activity by women or, more accurately, the expectation that women could and would perform commercial duties

\footnotetext{
${ }^{80}$ Irwin, Anna Maria van Schuurman, 7-9; Trevor J. Saxby, The Quest for the New Jerusalem: Jean de Labadie and the Labadists, 1610-1744 (Dordrecht, 1987).

${ }^{81}$ Van Schuurman was also an accomplished painter, of no small talent.
} 
gave women uncommon opportunities for self-expression. Nevertheless, commercial activity was intimately tied to women's roles as wives and mothers. At higher levels of commercial participation, for example, as merchant-traders, the connection with domesticity is sometimes hardly recognizable. Yet, even among women merchanttraders, there were subtle indications of a commercial activity-domesticity connection. For example, on the 1679 voyage of Margaret Hardenbroeck's, King Charles, described by Jasper Dankaerts, Hardenbroeck took her eleven year old daughter, Annetje Philipse. ${ }^{82}$ Also, Maria van Rensselaer survived seven pregnancies, the first of which gave her the earlier mentioned debilitating illnesses, from which she suffered for the rest of her life. Despite her illnesses and the death of her husband when she was only twenty-nine years old, she successfully managed Rensselaerswijck in widowhood. ${ }^{83}$ One can only speculate about the difficulties encountered by Maria as she tried to govern a household of young children, particularly while she was pregnant. When her illness was in remission she went about on crutches. ${ }^{84}$ Dankaerts made mention of a

\section{${ }^{82}$ Dankaerts Journal, 85.}

${ }^{83} C M V R, 3$; Christoph, "Worthy, Virtuous Juffrow," 25-30. She was perpetually pregnant or nursing between 1663 and 1673 . Jeremias wrote to his mother in 1665, "There are many here who presume that she will recover if, please God, she should again come to be in childbed, which, please God, may be expected in three or four months." "Jeremias van Rensselaer to Anna van Rensselaer, April 15, 1665," CJVR, 377. Christoph also makes the point mobility would have been especially difficult for Maria since her center of balance moved as the fetuses developed during pregnancy [30].

${ }^{84}$ Christoph, "Worthy, Virtuous Juffrow," 30, also makes the point mobility would have been especially difficult for Maria since her center of balance moved as the fetuses developed during pregnancy. In addition, her last child, Jeremias, was born shortly after the death of her husband. CMVR, 3 . 
visit to Maria van Rensselaer during her widowhood and revealed, "In her last childbed, she became lame or weak in both of her sides, so that she had to walk with two canes or crutches." ${ }^{85}$ In September 1680 she replied to Reygart [Richard] van Rensselaer, her deceased husband's brother and the last remaining children of the first patroon, who had complained Rensselaerswijck was not producing a profit,

\begin{abstract}
"That the friends in Holland through the war have suffered great losses makes us heartily sorry, God knows, but consider, dear brother, whether to lose my health and in addition to lose my property and my dearest partner and to be left with six children and such an encumbered estate is not hard on me either, especially, to sit here and not to know what I have and to get further and further in debt, for as long as I remain thus in possession of the undivided estate it will be nothing but loss to me and to the friends." 86
\end{abstract}

Dutch women expected marriage and motherhood as a social mandate.

However, many woman found fulfillment in domesticity in ways perhaps many

husbands and fathers did not. Nevertheless, as the above excerpt from Maria van

Rensselaer's letter indicates, the addition of commercial responsibilities to the duties of domesticity was sometimes overwhelming. Maria van Rensselaer's de facto management of Rensselaerswijck made her exceptional, but not because she was

${ }^{85}$ Dankaerts Journal, 317.

86“"Maria van Rensselaer to Reygart van Rensselaer, December, 1680," CMVR, 38. "Friends" probably refers to the other investors in Rensselaerswijck. While this letter implies Maria desired division of the estate, she was more concerned about a full accounting of assets and liabilities. There were several people, as blood relatives, through marriage, and as investors, who made claims on Rensselaerswijck. I believe she implied division of the estate at this point in her life because she felt overwhelmed. 
female. Management of Rensselaerswijck during this period included protecting the patroonship from seizure by the English government, legal challenges from interlopers like Robert Livingston, the very real possibility of bankruptcy owing to accumulating debts, and efforts to make the venture profitable through commercial agriculture. ${ }^{87}$ Nevertheless, the addition of a debilitating illness and the responsibilities of motherhood made the success of Maria's subsequent efforts to keep the patroonship intact extraordinary. That she was also a woman who, with other Dutch women in seventeenth-century New York, were beginning to discover the debilities ascribed to women under English law, makes her success unparalleled.

Women's commercial activity began to decline gradually in the seventeenth century after the English assumed political control of the colony in 1664. Changes were initially subtle and occurred in response to anglicization as it was expressed through law. Records of debt litigation show little change for women prior to the brief period of the second Dutch administration of the colony in 1673 through 1674 . Nevertheless, the process of anglicization of law began soon after English expropriation of New Netherland.

Soon after the 1664 seizure of New Netherland by England, purposeful efforts to substantively and procedurally anglicize the law were started by English administrators on behalf of the Duke of York. Singularly, the changes made by the English proprietary governments were inconsistent and inconsequential. However, in aggregate, they

${ }^{87}$ Livingston claimed a share of the patroonship owing to his marriage to widow of Nicolaes van Rensselaer. CMVR, 5. 
pushed Dutch women further to the periphery of commercial activity. Initial efforts toward anglicization of law occurred with development of the Duke's laws, which were promulgated in the spring of $1665{ }^{88}$ However, the administrative efforts of New York's first proprietary governor, Richard Nicolls, were not only aimed at initiating replacement of Dutch jurisprudence with English. Changes were also intended to deny local governance to Long Island English Puritans. When living under Dutch administration, the Puritans there developed laws and legal procedures based on New England bible codes and English jurisprudence rather than adhere to unfamiliar and, for them, religiously untenable Roman-Dutch law and procedure. ${ }^{89}$

From the beginning of the English expropriation of New Netherland, English governors sought hierarchical structure in administration of the colony. The primary instrument used to effect change was law. The system implemented by Governor Nicolls was designed to focus authority in the governor. It included at the summit, the Court of Assizes, on which sat the governor, the council, and justices of the peace. Jurisdiction included criminal, equity, and civil cases over $£ 20$. At the next level were the courts of session, in which civil cases of more than $£ 5$, but less than $£ 20$ were heard. At the lowest level were the town courts that handled civil cases involving less than

${ }^{88}$ Johnson, "The Advent of Common Law in Colonial New York," in Billias, ed. Law and Authority in Colonial America, 76. Although the Duke's Laws were initially applied to limited areas of New York, they set a precedent for hegemonic anglicization of law.

\footnotetext{
${ }^{89}$ Ibid.
} 
$£ 5 .^{90}$ More significantly, jury trials were an optional feature of adjudication above the town court level. ${ }^{91}$ Most of the Dutch in the colony were unfamiliar with the concept of jury trials and seldom made use of them. ${ }^{92}$ Nevertheless, during the earlier proprietary period, i.e., pre-1673, structural and procedural changes in the court system were not uniformly applied throughout the colony.

Realizing the potential for creating ethnic divisions, early proprietary governors like Richard Nicolls were prudent in effecting changes in the court structure of New York. For example, while significant changes were made affecting particularly Puritan colonists, structural alterations came gradually to Dutch settlements along the Hudson, including Albany and its environs. Proprietary governors acted with circumspection in the preponderance of Dutch colonists. In addition, the articles of capitulation, to which the Dutch were required to agree as a condition of surrender, included concessions like continuation of pending suits, enforcement of pre-acquisition contracts, and allowance for Dutch inheritance practices. ${ }^{93}$ Therefore, in addition to avoiding alienation of the resident majority non-English population, wholesale changes in administration of law were not incorporated because they would have created an unmanageable logjam of

${ }^{90}$ Goebel, "The Courts and the Law in Colonial New York," 253-254.

${ }^{91}$ See for example, the appointment of a twelve man jury, August 22, 1665, RNA, 5: $284-285$.

${ }^{92}$ Murrin, "English Rights as Ethnic Aggression," 60.

93،"Articles of Capitulation,” NYCD, 2: 250-253. 
litigation for English administrators. ${ }^{94}$

Other specific features of the articles of capitulation also mitigated potential difficulties in the transition to English administration of law and facilitated continuation of commercial activity by women. In addition to enforcement of private contracts negotiated under Dutch administration, the articles conferred upon the Dutch the status of denizens, which authorized trade with England and her colonies. Further, in ostensible violation of the Navigation Acts, direct trade with the Netherlands was accorded Dutch merchant-traders for a period of six months. ${ }^{95}$

While Nicolls was one of the most effective proprietary governors, his actions in dealing with the Dutch were demanded by the exigencies of his task. ${ }^{96}$ Except for Long Island which, owing to the Puritan presence, presented its own difficulties, any government or legal structure he initiated in the colony at the local level would by necessity have been dominated by the Dutch or Dutch-acculturated population. Using force to bring about wholesale change was never a consideration. Avoiding alienation of the majority population was an important consideration for developing the profitability of the colony. Granting status as denizens offered the legal fiction of

\footnotetext{
${ }^{94}$ Describing the jurisprudence and practice of law in New Netherland as Dutch or Roman-Dutch, does not imply ethnic uniformity in the colony. Nevertheless, although the population of New Netherland was, "too great a mixture of nations," they lived under Dutch administration of law. Charles Lodwick, "New York in 1692," Collections of the New York Historical Society, 2d ser., vol. 2 (New York, 1842), 244, qtd. in Goodfriend, Before the Melting Pot, 3.

95“"Articles of Capitulation,” NYCD, 2: 250-253.

${ }^{96}$ Ritchie, The Duke's Province, 19.
} 
English citizenship upon the non-English population of New York, which gave them opportunity to adapt their institutions to those devised by English colonial administrators. ${ }^{97}$ Nevertheless, the structural and other alterations made by English governors like Nicolls were designed to purposefully move New York commerce into the sphere of restrictive English commercial policy. At the same time, they avoided creating ethnic or other divisions that would negatively influence trade and therefore, profitability.

The articles of capitulation, Duke's Laws, and initial changes in the court structure had little effect on Dutch participation in commerce. In addition to avoiding alienation of the Dutch, proprietary governors looked after their own interests. For example, Francis Lovelace was an unnamed investor in the Duke of York, a trading vessel owned by Margaret Hardenbroeck and her husband Frederick Philipse. With his brother, Thomas, he also owned shares in the ships Hopewell and Good Fame. ${ }^{98}$ Cooperation with Dutch merchant-traders like Philipse caused Andros troubles with

\footnotetext{
${ }^{97}$ Under seventeenth-century English law, conferring denizenship upon foreign born individuals was a prerogative of the monarch that allowed its recipients dual status as an alien and natural-born citizens; or, "a position midway between an alien and natural-born or naturalized subject, being able to take lands by purchase or devise, but not able to take lands by descent." H.C. Black, Black's Law Dictionary, 434. Specifying retention of Dutch inheritance practices in the surrender agreement may have been an effort to overcome debilities of descent conferred by denizenship. NYCD, 2: 251.

${ }^{98}$ Biemer, Women and Property in Colonial New York, 38. He also traded through Dutch agents, including Eagidus Luyck, Francis Hooghlandt, Nicholas Governeur, and Isaac Bedloo. Cathy Matson, "The 'Hollander Interest' and Ideas about Free Trade in Colonial New York: Persistent Influences of the Dutch, 1674-1764," in Zeller, ed. A Beautiful and Fruitful Place, 251-268: 253.
} 
English merchants which led to his recall by the Duke of York to answer charges of

malfeasance. In addition to a letter of recall personally from the Duke, on May 24,

1680, Andros received notice from the Duke's secretary, Sir John Werden, explaining

why his government was under investigation. Werden wrote,

"You may perceive both by the Duke's letter and Mr. Lewen's com[m]ission that the Chiefe thing we enquire after is the chardge and revenue of your government of which we have met calculacons soe vastly differing from your account that as on one side we have not yet sufficient evidence to believe them certaine, soe on the other we cannot but be solicitous to have a strict enquiry made into the businesse by a person wholely unconcerned (such as the Duke takes Mr. Lewen to be) though it were but to justify you and the rest of the officers under you; which is indeed what I expect from the scrutiny, rather than to find the Duke or you soe grossly abused in the yearly account." ${ }^{\circ 9}$

Among the accusations made by Lewen who, as an English merchant, was

hardly unbiased, was collusion with Dutch merchants to avoid competition from English

merchants. In his report he stated,

"I have been informed by severall in New Yorke that there hath been such particular Connivance practiced to some few Dutch Merchants viz ${ }^{\mathrm{t}}$ ffredrick Phillips \& Stephanus van Cortlandt the Gov ${ }^{\text {rs }}$ Trustee there both in regard of Trade $\&^{\mathrm{e}}$ by such gentlemen dealing $\mathrm{w}^{\text {th }}$ them, $\&$ such rigid usage to others that hath caused a great Obstruccon to Trade by those discouragem ${ }^{\text {ts }}$ given indeed to all English both by the Gov $^{r}$ himselfe and persons imployed by him, having suffered goods to be brought in contrary to the Act of Navigcon \& Trade, and hath soe terrifyed severall persons who did complaine of the same that none dared to appeare to prosecute which hath not only been hard on the English Inhabitants there, but hath much hindered \& prevented many others from Barbadoes and

\footnotetext{
${ }^{99}$ NYCD, 3: 283.
} 
other places both from tradeing thither, and from comeing to settle with their ffamileys $\mathrm{w}^{\mathrm{ch}}$ may be prevented for the future by placeing such discreet $\&$ honest Offic ${ }^{\text {rs }}$ that Justice may be equally distributed to all men, \& yo ${ }^{\mathrm{r}}$ Roy $^{\mathrm{ll}}$ Highn $^{\mathrm{s}}$ not deceived \& abused." 100

In mentioning the Andros-Philipse commercial connection, Lewen reflected the typically English social and legal assumption that commercial transactions were the responsibility and prerogative of the male head of the household. Through this patriarchal assumption, any member of Frederick Philipse's family who participated in commerce with Andros was acting under the authority of Philipse. That is the concept of paterfamilias prevailed. ${ }^{101}$ However, the foundations of the Philipse family commercial power were built by Margaret Hardenbroeck prior to her marriage to Philipse. Owing to Hardenbroeck's intense commercial activity and opportunism during the proprietorship, Andros' commercial activities with the Philipse family were often through her.

Hardenbroeck used a variety of legal and perhaps illegal means to adapt to the commercial changes wrought by English expropriation of New Netherland. Apart from the exceptions made in the articles of capitulation and the one time exemption

${ }^{100}$ Ibid., 307-308. In accusing Andros of hindering settlement, Lewen spoke specifically to Andros' commission from the Duke to, "give all manner of encouragement to planters of all Nations, but especially to Englishmen, to come and settle under your government." Ibid., 216.

${ }^{101}$ For analyses of ways paterfamilias was applied in the southern colonies see, Terri Lynn Snyder, “'Rich Widows Are The Best Commodity This Country Affords': Gender Relations and the Rehabilitation of Patriarchy in Virginia," (Ph.D. dissertation, University of Iowa, 1992); Brown, Good Wives, Nasty Wenches, and Anxious Patriarchs, and Norton, Founding Mothers and Fathers. 
made by the Crown for the King Charles, the English government insisted on adherence to the conditions of the Navigation Acts. However, strict compliance with or enforcement of the Navigation Acts had the potential to sever or at least seriously interrupt important trade ties between New York and Europe established during the tenure of Dutch administration. ${ }^{102}$ In addition, it would disturb foundations of political liaisons proprietary governors found necessary to construct to govern effectively. ${ }^{103}$ Alienation of powerful commercial families like the Philipses and van Cortlandts would damage opportunities for building commercial networks the governors had begun to form to advance their personal interests and those of political consorts, Crown, and country. ${ }^{104}$

Margaret Hardenbroeck was a resourceful merchant-trader and she made efforts to adjust to changes in commercial regulations brought about by English acquisition of New Netherland. Direct and indirect evidence of financial connections between Hardenbroeck and Andros compels the conclusion of favoritism. The former is well

102،Governor Stuyvesant to the Duke of York," NYCD, 3: 163-164; "Petition of Peter Stuyvesant to the King and Privy Council,” Ibid., 164-165.

${ }^{103}$ Ritchie, The Duke's Province, 45-46.

104“Lewen's Report,” NYCD, 3: 307-308; “Governor Andros' Answer to Mr. Lewen's Report," Ibid., 312-313. Andros was particularly adept in establishing a political and financial base with important New York Dutch families. See, Ritchie, The Duke's Province, 100. Among the personal interests of New York proprietary governors was avoidance of unmanageable personal debt accrued for public expenditures. For example, the estate of Francis Lovelace was difficult to determine owing to his personal credit for public necessities with New York merchants and laborers. $N Y C D, 2: 587-588$. In the end, Andros was ordered to seize Lovelace's estate in order to satisfy debts he owed to the duke. Ibid., 3: 226. 
known to historians of early New York history. ${ }^{105}$ In 1677, Hardenbroeck appealed to the secretary of the duke of York, Sir John Werden, for what was in effect a grant of immunity from the Navigation Acts. She requested a Dutch ship she was interested in purchasing receive status as an English ship. Had permission been granted, she would have been able to trade freely between Europe and America. Werden informed Hardenbroeck through Andros that while the practice had been common in the past, it was no longer permissible. ${ }^{106}$

Over time, a politically and financially mutually beneficial relationship developed between Frederick and Margaret Hardenbroeck Philipse and Edmund Andros. ${ }^{107}$ An event that indirectly implies existence of a commercial relationship between Andros and Hardenbroeck occurred in 1680, during the period when Andros was recalled to English by the Duke. ${ }^{108}$ In his absence, the Margaret, one of two ships the Philipses had named for themselves in 1670, the other named the Frederick, was seized for customs violations by the Surveyor of Customs. ${ }^{109}$ Specifically, the ship's owners had not paid the ten percent ad valorem tax on goods imported on non-English

\footnotetext{
${ }^{105}$ Mariana van Rensselaer, History of the City of New York in the Seventeenth Century, 2 vols. (New York, 1909), 2: 217; Ritchie, The Duke's Province, 121; Biemer, Women and Property in Colonial New York, 40.

106“Sir John Werden to Governor Andros," NYCD, 3: 246-247.

${ }^{107}$ Ritchie, The Duke’s Province, 100.

108“Duke of York to Governor Andros," NYCD, 3: 283.

109،Lewen's Report," Ibid., 306. The Margaret was jointly owned by the Philipses, Thomas Delavel, and Jeremias van Rensselaer. Biemer, Women and Property in Colonial New York, 39; Ritchie, The Duke's Province, 86.
} 
ships. ${ }^{110}$ The Receiver General, William Dyre, took his post simultaneous with Andros' appointment as governor. In the absence of Andros, Dyre could not continue a practice with ships like the Margaret that may have been common previously. ${ }^{111}$

Clearly, as a woman Margaret Hardenbroeck exercised uncommon influence in the political and economic activities in proprietary New York. With perspicacity in business demonstrated prior to 1664 , Hardenbroeck was required to tap seldom used talents to adjust to changes after 1664 and particularly after 1674 when England acquired permanent possession of the colony.

After permanent acquisition by England in 1674, elite women like Hardenbroeck and Maria van Rensselaer experienced advantages that enabled them to cope with some of the legal changes that were unavailable to non elite women. Specifically, they were able to deal with the English in their own language, which although he was fluent in Dutch, Edmund Andros declared the official language of the courts in $1674 .{ }^{112}$ That is, while elite women could use the language of the courts those women unschooled in English could not. In combination with other efforts to anglicize the courts, including use of juries and several structural changes, mandating use of English may explain the decline in the number of female traders in the period from 1674 to 1700 in New York

\footnotetext{
${ }^{110}$ The ad valorem tax for goods on English ships was two percent. Ibid., 217.

${ }^{111}$ Ibid., 306.

${ }^{112}$ Ritchie, The Duke's Province, 140.
} 
and Albany found by Linda Biemer. ${ }^{113}$ However, distinctly different perceptions of patriarchy as it applied to law was also a factor in the apparent decline in commercial activity by women.

While extant records allow historians to know more about the activities of elite women like Hardenbroeck than non elite women, the records are sparse compared to those of elite men like Hardenbroeck's husband, Frederick Philipse. Therefore, a significant qualification about discussing the commercial activities of women in proprietary New York is the connection between English patriarchy and English jurisprudence. That is, as the court structure and legal procedure in New York became more anglicized, an assumption of English patriarchy is reflected in the records. Dutch women became more marginalized from commercial activity owing to assumption of paterfamilias at law. Coverture, by which the legal identity of married women under common law was subsumed into that of their husband, gave the appearance women could not act as commercial agents exclusive of their husbands under English law. Notwithstanding exceptions like premarital contracts and status as femme sole trader, women's legal ability to acquire and dispose of property was largely circumscribed. ${ }^{114}$ More significantly, if expression of law is a measure of collective social will as the nineteenth-century German school of jurisprudence founded by Karl von Savigny maintained, among its many functions English law was an instrument of expression of

\footnotetext{
${ }^{113}$ Biemer, "Criminal Law and Women in New Amsterdam and Early New York," 76.

${ }^{114}$ Shoemaker, Gender in English Society, 196.
} 
English patriarchy. ${ }^{115}$ That is, in the early modern period patriarchy existed in every European culture, but each culture possessed unique patriarchal characteristics. ${ }^{116}$ Law was one conveyance for the patriarchal identity of each culture.

English patriarchy was inherent in English law regardless of the area of law discussed, including common, ecclesiastical, local and equity law. English common law, which was highly circumscriptive of women in general and wives in particular, did not provide the basis for jurisprudence in New York until after Leisler's Rebellion, 1689-1691. ${ }^{117}$ Nevertheless, the assumption of paterfamilias was apparent in the structural and procedural changes that occurred prior to 1691.

As noted by historians, women in general and wives in particular continued to play a vital role in the New York economy long after the English expropriation. ${ }^{118}$ However, evidence of their contributions in court records became less evident over time

${ }^{115}$ Patterson, Jurisprudence, 410-414; Shoemaker, "Ideas about Gender," Gender in English Society, chapter 2: 15-58, provides a biblical and philosophical basis for patriarchy and gender as it was expressed by the early modern English.

${ }^{116}$ Patriarchy and its expression through law was not static. For example, the severe circumscriptions contained in English common law were internally and externally ameliorated. The former through instruments like pre-marital agreements and status as femme sole trader and the latter by appeal to ecclesiastical and other courts that did not use common law jurisprudence. Shoemaker, Gender in English Society, 196; Hoffer, Law and People in Colonial America, 5-7.

${ }^{117}$ Johnson, "The Advent of Common Law in Colonial New York," 74.

${ }^{118}$ Richard Morris, "Women's Rights in Early American Law," Studies in the History of American Law, 173-197; Dexter, Colonial Women of Affairs; Jordan, "Women Merchants in Colonial New York"; Gundersen and Gampel, "Married Women's Legal Status in Eighteenth-Century New York and Virginia"; Biemer, Women and Property in Colonial New York. 
owing to cultural patriarchy expressed in English law. That is, while anglicization of law in New York gradually compelled women to the periphery of commercial activity, initial decreases in levels of commercial activity by women in the proprietary period were more apparent than real. Changes in jurisprudence were slow in coming to upstate areas of New York, but as the percentage of Dutch emigration and increased English immigration from areas like Massachusetts increased, English patriarchy became more entrenched in New York. ${ }^{119}$ Women continued vital roles in commerce, but as Deborah Rosen discovered, their roles were marginalized. Specifically, rural women contributed to their families and the economy through domestic functions like butter and cheese making and urban women contributed by acting as adjuncts to their husbands. ${ }^{120}$

However, it is evident that not all wives of commercially active men in eighteenth-century New York were subordinate to their husbands. Some acted as primary agents of commerce in their families. However, they tended to be elite women. For example, Mary Alexander, daughter of John Spratt, who was a Scot, and Maria De

\footnotetext{
${ }^{119}$ Immigration of English to New Netherland began prior to English expropriation of the colony as found by Oliver Rink, "The People of New Netherland: Note on Non-English Immigration to New York in the Seventeenth-Century," New York History, vol. 62, no.1 (1981), 5-42: 41. English immigrants streamed into New York following the 1664 expropriation, but owing to out-migration did not stabilize. In April 1666, Richard Nicolls complained to Lord Arlington of, "new comers of our own nation, who at first (as wee find by experience) are blowne up with large designes, but not knowing the knacke of trading here to differ from most other places, they meet with discouragements and stay not to become wiser." "Colonial Nicolls to Lord Arlington, April 9, 1666," NYCD, 3: 114. The multitude of reasons for English out migration are explained by Goodfriend, Before the Melting Pot, 54.
}

\footnotetext{
${ }^{120}$ Rosen, "Women, the Courtroom, and the Marketplace," Courts and Commerce, chapter 5: 95-110.
} 
Peyster Spratt, who was Dutch and the widow of Samuel Provost, brought a successful mercantile business to her second marriage with James Alexander in 1721. Despite her new status as femme covert, Mary Alexander continued to operate her business as if she were femme sole trader. The story was related by her husband of how she returned to work at the store the day following the birth of one of their five daughters. ${ }^{121}$

More revealing for what it indicates about wives' independence in commerce was a letter to the editor in Peter Zenger's New York Weekly Journal, in 1734. The authorship of the letter is in doubt owing to a crusade against Governor William Cosby by a group of prominent New York politicians who used the Journal as their voice. Nevertheless, owing to the need for plausibility the letter could have been written by the women to whom it was ascribed. ${ }^{122}$ Among other comments, the letter contained the following:

"We are House keepers, Pay our taxes, carry on Trade, and most of us are she Merchants, and as we in some measure contribute to the Support of Government, we ought to be Intituled to some of the Sweets of it; but we find our selves intirely neglected, while the Husbands that live in our Neighborhood are daily invited to Dine at Court."123

The letter is important not only because it indicates the existence of women

${ }^{121}$ Nicholas Varga, "Mary Spratt Provoost Alexander," Notable American Women, 1607-1950, Edward James, ed. (Cambridge, MA., 1971), 1: 35-36.

${ }^{122}$ The anti-Cosby faction included, James Alexander, William Smith, Jr., Cadwallader Colden, Rip van Dam, and Lewis Morris, Sr. and Lewis Morris, Jr. Jordan, "Women Merchants in Colonial New York," 412-413.

${ }^{123}$ New York Weekly Journal, January 21, 1734. 
merchants in New York City, but also because it asserts their independence. The "she merchants" did not claim equality with their husbands, but expressed a level of competence and contributions to the colonial economy commensurate with those of any other male and female entrepreneur. The implication was their entrepreneurial and financial capacities entitled them to participate politically.

While eighteenth-century evidence hints at women's involvement in commerce, it pales in comparison to seventeenth-century court records that reflect Dutch legal influence. Therefore, while women continued to participate in commerce in the late seventeenth and eighteenth centuries, they experienced legal debilities that arose from ascendance of common law. ${ }^{124}$ Nevertheless, there is an interesting conclusion suggested by the stories of Mary Alexander, the "she merchants" in Zenger's newspaper, and a few other women mentioned in eighteenth-century records. While the law limited the legal capacities of women to contract and acquire property, it did not absolve them of commercial responsibilities important to the support of their families.

Historians like Elizabeth Dexter, Richard Morris, and others have demonstrated that despite the debilities conferred on them by English law, wives performed essential commercial responsibilities in colonial New York. ${ }^{125}$ However, while these authors

${ }^{124}$ Morris, Studies in the History of American Law, 166-167; Rosen, Commerce and Community, 100-101, revealed that while some married women were able to perform mercantile functions independently as femme sole traders, most acted with limited independence owing to their marital status. Most independent women entrepreneurs were widows.

${ }^{125}$ Morris, Studies in the History of American Law, 173-197; Dexter, Colonial Women of Affairs; Jordan, "Women Merchants in Colonial New York." 
displayed evidence to support their theses that women were active in commerce, recently Deborah Rosen used the same information and other evidence to compile a statistical analysis that shows the negative effects of legal circumscription on women's commercial activity. ${ }^{126}$ She built upon a trend discovered for the late seventeenth century by Linda Biemer. ${ }^{127}$

What is evident from studying the records of New Netherland and seventeenthcentury New York is both groups of historians are correct. The court records of New Netherland are particularly important to historians of early American women owing to the frequent appearance of married women, unmarried women, and widows in court. These records offer information about law and more importantly, its application by adjudicators. Roman-Dutch law asserted subordination of wives to their husbands with important qualifications that conferred commercial responsibilities on them. Through those responsibilities they also acquired opportunities uncommon for married women in early modern Europe and America. ${ }^{128}$ However, for most married women, commercial activity was intimately tied to promoting the financial interests of their families rather than self-aggrandizement.

If wives were the partners of their husbands with commensurate financial responsibilities and opportunities during Dutch legal administration, as anglicization of

\footnotetext{
${ }^{126}$ Rosen, "Mitigating Inequality: Women and Justice in Colonial New York," 313-329; Courts and Commerce.

${ }^{127}$ Biemer, Women and Property.

${ }^{128}$ Morris, Studies in the History of American Law, 176-177.
} 
law developed their status as subordinate partners became entrenched. However, throughout the Dutch and English colonial periods, women's participation in commerce was largely to promote the financial conditions of their families. The humanist, religious, political, and especially commercial development of the early modern Netherlands profoundly affected ways women participated in commerce in areas influenced by Dutch culture and society. However, concomitantly with opportunities to participate in the Dutch golden age of commerce, orthodoxy insisted female significance was based on marriage and motherhood. Dutch wives in Europe and America improved their personal status by using legal and social commercial independence successfully to promote the financial welfare of their families.

As anglicization of law in New York became entrenched, women found their commercial independence increasingly circumscribed. The individual effects for some families was husbands' legal responsibilities for commerce increased while other families experienced financial stagnation or worse. Anglicization of law had the aggregate effect of limiting full expression of ability by a large group of commercially talented people who, in aggregate, had potential to significantly affect the prosperity of the colonial economy. Women's declining responsibility for commerce with commensurate ability to make independent commercial decisions affected families and through them, the colonial economy. New York's commercial economic orientation continued to expand during the eighteenth-century, but denial of women's former place in commerce limited its potential. 


\section{Chapter Four}

\section{Women and Power in New Netherland and Seventeenth-Century New York: A Different Model of Patriarchy in Early America}

"Governor Dongan has been up here all winter and in the summer occupied my house in the county. Now again, Governor Andros has come here. ..."1

In the New Amsterdam Court of Burgomasters and Schepens' first session of 1654, Adriaen Keysar sued several individuals who had not paid him money they owed. Among the defendants was (Jan) Harmen[sen], a cooper who was previously mentioned in reference to Mrs Anthonie. Keysar maintained Harmensen owed him fl49:12 (fortynine florins, twelve stuivers) on an account pending since 1652. Harmensen acknowledged the account, but since his wife kept the accounts he could not supply information about how much they had paid on this one. He reported, "that there was something due at that time, but as his wife has gone to Fatherland, and he does not know if she has paid pltf. he requests delay until his wife's return."2 Despite the request, the court ordered Harmensen to pay what Keysar could prove.

1"Maria van Rensselaer to Richard van Rensselaer, September 19?, 1688," $C M V R, 185$. Dongan stayed on the van Rensselaer estate between October 25, 1687 and March 28, 1688. His absence from New York City required giving extraordinary power for administration to Major Anthony Brockholls. Dongan and Andros were in the area to negotiate a treaty with the five nations of the Iroquois. $N Y C D, 3: 438-444,557-561$.

${ }^{2} R N A$, I: 147 . 
Twenty-four years later, Maria van Rensselaer penned a letter to her brother-inlaw, Richard van Rensselaer, living in Holland. She informed him she was unable to get the accounts of her late husband together owing to the presence of Governors Dongan and Andros. ${ }^{3}$ Van Rensselaer neglected to mention the large contingent of soldiers Dongan brought with him to counter a potential French presence. The contingent of soldiers with Dongan numbered 200 with 800 more expected to arrive. ${ }^{4}$ Dongan camped and provisioned the soldiers at Rensselaerswijck.

When she assumed authority over Rensselaerswijck as official treasurer and de facto director in November 1678, Maria van Rensselaer acquired responsibility for a commercial venture burdened with significant financial encumbrances. ${ }^{5}$ Despite the fiscal condition of the patroonship and staggering personal hardships, Maria managed Rensselaerswijck with adequate skill to keep the property in the van Rensselaer family. In doing so, she laid the foundation for an American van Rensselaer dynasty.

Beyond the encumbrances of ill health, the death of Jeremias, and financial hardship, Maria van Rensselaer tried to help secure a patent for the property from the provincial government. She did so largely by entertaining provincial governors. In June 1678 she informed Richard [Reygart] van Rensselaer, her brother-in-law, "We are

3“Maria van Rensselaer to Richard van Rensselaer, September 19?, 1688." CMVR, 185. 184.

4‘"Kiliaen van Rensselaer to Richard van Rensselaer, September? 1687,” Ibid.,

${ }^{5}$ Ibid., 4. Including debts and unsettled accounts relating to the heirs, including her own children. 
longing very much for the arrival of governor (Andros) in the hope that something may have been done in the matter of the colony." She coordinated her efforts with those of Richard van Rensselaer who used unofficial channels in Holland. Those channels included Hetwich Agnes, countess of Brederode, who intervened with Mary, Princess of Orange, who petitioned her father, James, duke of York. ${ }^{7}$

These examples of women who assumed uncommon authority and responsibilities reveal important facets about the dynamics of gender-based power sharing among the Dutch in Holland and seventeenth-century America. Like most women in the rest of Europe and early America, these women experienced limits placed on them by western patriarchy. The Dutch did not appoint any women governor-general of New Netherland and, like the Mayflower Compact and the United States Constitution, no women signed the Remonstrance of New Netherland in $1653 .{ }^{8}$ Nor did any woman receive an appointment as clergy to the Reformed churches in the colony. ${ }^{9}$ In these respects, patriarchy in New Netherland was similar to English patriarchy in New England and the Chesapeake. However, there were significant differences from

6“Maria van Rensselaer to Richard van Rensselaer, June 1678,” Ibid., 22.

7"Richard van Rensselaer to Robert Livingston, April 11, 1683," Ibid., 97. A warrant was sent of Andros in June 1678, that allowed him to issue a patent for Rensselaerswijck. However, the warrant had several qualifications, including the exemption of Fort Orange, payment of taxes, and observation of administration by the provincial government. NYCD , 3: 269-270. A patent excluding Albany, was granted on November 4, 1685 by Governor Dongan. CMVR, 7.

${ }^{8}$ Mary Beth Norton, Founding Mothers and Fathers: Gendered Power and the Forming of American Society, (New York, 1996), 4.

${ }^{9} N Y C D$, I: 552. 
English patriarchy. Despite her anonymity, Jan Harmensen's wife, who handled all the family's accounts, was more like Maria van Rensselaer and the countess of Brederode than the "good wives" of colonial New England and the Chesapeake. ${ }^{10}$

In the historiography of early American women, most authors approach the study of patriarchy through the structure and administration of law. For many historians, the impotence of early American women was based on the patriarchal structure of law.

They do not totally dismiss the effects of environment. Nevertheless, their focus is on examples from court records that support their position that women's inability to control property was a major factor in the practice of early American patriarchy. ${ }^{11}$ In contrast, a few historians take a more balanced approach by recognizing structure was not the only defining characteristic of American patriarchy in a sex-skewed, labor deprived colonial environment. $^{12}$

Dutch women in seventeenth-century America shared power with men in a variety of structural and psychological ways that took little notice of status and wealth.

\section{${ }^{10}$ Ulrich, Good Wives, 7.}

${ }^{11}$ Salmon, Women and the Law of Property, xii-xiii; Brown, Good Wives, Nasty Wenches, and Anxious Patriarchs, 30; Rosen, Courts and Commerce, 9; Perhaps the foremost author of this genre of the history of early American women is Mary Beth Norton, whose works include, "Eighteenth-Century Women in Peace and War: The Case of the Loyalists," WMQ, $3^{\text {rd }}$ ser., no 33 (1976), 386-409; "The Myth of the Golden Age," Women in America: A History, Carol R. Berkin and Mary Beth Norton, eds. "introduction"; "Gender and Defamation in Seventeenth-Century Maryland," $W M Q, 3^{\text {rd }}$ ser. no. 44 (1987), 3-39; Founding Mothers and Fathers.

${ }^{12}$ Julia Cherry Spruill, "Under the Law," Women's Life and Work in the Southern Colonies, chapter 16: 340-366; Richard Morris, "Women's Rights in Early American Law," Studies in the History of American Law; Ulrich, Good Wives, 38. 
That is, the foundation of Dutch women's ability to decide how they administered their property, the future of their children, and their own lives was cultural. It was expressed through custom and in limited ways through law.

Jan Harmensen's revelation that his wife knew more about the Keysar account than did he, shows she may have had responsibility for most of the financial affairs in the Harmensen family. More specifically, it suggests she had responsibility for making sure the bills were paid. Records of husbands' deference to their wives' knowledge of accounts are not common in the annals of New Netherland, but occur frequently enough to show husbands were comfortable with the arrangement. Cases in which wives appeared independently in court in debt litigation and other civil suits are more common. The plentitude of those cases further reinforces the conclusion that husbands willingly relinquished duties related to finances and public representation of family interests to their wives.

More significantly, husbands' acceptance of their wives' financial and public roles implies that decision making within Dutch families did not fit the patriarchal model of family structure used by some historians of early American English women. In addition, it does not fit the paternalism some historians have used to characterize early American families. Some authors maintain paternalism was merely a veneer over a deeply-rooted rigid patriarchy. ${ }^{13}$ Unfortunately, the records do not directly reveal why Dutch husbands often deferred to their wives in decision making about finances and public representation. Some were undoubtedly content to do so out of indolence. For

\footnotetext{
${ }^{13}$ Brown, Good Wives, Nasty Wenches, and Anxious Patriarchs, 322.
} 
many, it provided opportunities to pursue other responsibilities, as in the circumstance of merchant-traders and factors. Maria van Rensselaer's training and willingness to assume duties related to commerce, enabled her husband, Jeremias van Rensselaer, to carry out responsibilities related to factoring and management.

However, the reasons why husbands like Jorsey (George) Rapalje, a tavenkeeper, deferred to his wife, Catelyntje, are inclusive. ${ }^{14}$ Catalyntje kept the accounts for the tavern and, owing to that circumstance, often represented the business in court. ${ }^{15}$ Some of Jorsey's activities, based on his appearances in court, may provide a clue to why Catalyntje was the bookkeeper for the family business. For example, Jorsey Rapalje was also a landlord. In August 1653, Poulus Schrick sued Rapalje for an outstanding account of f178:13:8 for received goods. However, Rapalje produced an offset account for back rent on a house he rented to Schrick. ${ }^{16}$ Similarly, Rapalje found it necessary to sue Hendrick Hendricksen, who vacated the house Rapalje rented to him without paying the back rent. ${ }^{17}$

Like many people in New Netherland, Rapalje may have also carried on local trading. The records indicate he brought suit against various people between September

${ }^{14}$ Unlike many women in the records of New Netherland, the patronymic of Catalyntje Rapalje was not identified.

\footnotetext{
${ }^{15} R N A, 1: 8,94,109,338 ; 3: 408,424$.

${ }^{16}$ Ibid., 105.

${ }^{17}$ Ibid., 377.
} 
1653 and November 1661 for what appear to be commercial accounts. ${ }^{18}$ In addition, in July 1661, he requested appointment as harbormaster. ${ }^{19}$

Owing to the sparsity of records about Catalyntje and Jorsey Rapalje's relationship, only generalizations are possible. Clearly, Catalyntje's acceptance of responsibility for managing the family's business accounts gave Jorsey opportunities to pursue other ventures. In addition, she was obviously educated enough to perform her responsibilities successfully. ${ }^{20}$ Additionally, the relationship between Catalyntje and Jorsey and that of others like theirs' shows additional information needs to be included in the historiography of women in early America.

It is as important to avoid oversimplification about the seventeenth-century American Dutch as it is with any other ethnic group. Life in different geographic areas of early America was too complex for absolute labels on individuals and societies. ${ }^{21}$ Nevertheless, based on records like that of Catalyntje and Jorsey the Dutch did not view patriarchy in the same way as colonists in English colonies. Inclusion of wives in the records of New Netherland shows they participated more frequently in the public affairs of their families than did women in other colonies. In addition, they participated in

\footnotetext{
${ }^{18}$ Ibid., 1: 114; 3: 408.

${ }^{19}$ Records of the Orphanmaster's Court, 2: 97.

${ }^{20}$ However, it cannot be determined if her education was formal or informal.

${ }^{21}$ Brown, Good Wives, Nasty Wenches, and Anxious Patriarchs, 322-323.
} 
ways uncommon for women in English colonies. ${ }^{22}$

Moreover, the manner in which wives' participation in public affairs was

recorded in court minutes suggests something greater than mere acceptance of women in those roles. Court records were not literary venues for embellishment in any colony. Nevertheless, the casual way wives were included in the court records of New Netherland points to an application of utilitarianism that was not based on gender. With noted exceptions Dutch law gave precedence for decision making about property to husbands and women were excluded from formal positions of power in government and religion. But, on a familial level women in general and wives in particular were not adjunctive. As indicated, control of labor and property is a measure of patriarchy. ${ }^{23}$ This does not apply to the New Netherland Dutch. Jan Harmensen's wife's maintenance of financial accounts and more important, Jan Harmensen's inability to produce information about them in court, suggests the degree of her authority over labor and property. In her absence, Jan Harmensen was unable to prove the amount of his indebtedness (property) which indirectly affected his future labor.

On occasion, litigants and court officials requested or required wives to produce authorization from their husbands allowing them to represent family interests in court. However, the examples are so few they are anomalies. There was only one recorded

\footnotetext{
${ }^{22}$ That is not to say women in English colonies never participated in the public affairs of their families. See, for example, Elizabeth W. A. Dexter, Colonial Women of Affairs: Women in Business and the Professions in America Before 1776, (Boston and New York, 1931); Spruill, Women's Life and Work; Morris, "Women's Rights in Early American Law," Studies in the History of American Law.

${ }^{23}$ Brown, Good Wives, Nasty Wenches, and Anxious Patriarchs, 4.
} 
example of a husband in New Netherland who applied his legal authority as a husband to prevent his wife's control of property. ${ }^{24}$ Claes van den Bergh of Fort Orange (Albany) sued the wife of Jan Martensen for various items, including a testament with silver mountings, stockings, silver buttons, and linen caps, which his wife had sold without his permission. The Court of Fort Orange and Beverwijck found in favor of van den Bergh. ${ }^{25}$ While this was the single example of a husband who used the law to restrict his wife's control of property, the courts did so on at least two occasions. Interestingly, one of those occasions was when Catalyntje Rapalje was not allowed to represent her husband. In a continuation of the previously mentioned suit by Poulus Schrick, the Court of Burgomasters and Schepens of New Amsterdam disallowed the appearance of Catalytje for her husband. ${ }^{26}$

The second record of the court's restriction of a wife's acting for her husband also occurred in the Court of Burgomasters and Schepens. In the court session on October 5, 1654, represented by his wife, Annetie [Anneken], Egbert van Borsum sued Johannes van Beeck. The magistrates denied Annetie's advocacy of the suit unless she was able to show authority from her husband. ${ }^{27}$

To delay action by the courts, on at least three occasions, male defendants

${ }^{24}$ Grotius, The Jurisprudence of Holland, 29.

${ }^{25}$ FOCM, 2: 227-228; Martha Shattuck, “A Civil Society," 163-164, provides greater detail of this case and significant commentary about its meaning.

${ }^{26} R N A$, I: 109.

${ }^{27}$ Ibid., 248. 
required women who sued them to produce authority from their husbands or that their husbands appear. In March 1655, Lubbert van Dincklagen demanded Cornelia Schellinger, who sued him for fl1156, to exhibit authority from her husband, "and that she shall then institute her action in writing." 28 On March 13, 1656, Jacob van Cowenhoven, whom Merritie Joris sued for a debt of fl234.9, requested to settle with her husband..$^{29}$ One week later, on March 20, 1656, acting for her husband, Aryaen Woutersen, Catalyntje Verbeeck was the defendant in a suit brought by Jacob Steendam. Steendam insisted, "he has nothing to do with the woman, requests that the husband, who was summoned, shall appear in person." 30

Finally, only one record exists of a case in New Netherland in which a wife produced documentation of her husband's permission to act for him. In August 1660, Maritie Tomas, wife of Poulus van de[r] Beeck, "in virtue of procuration from her husband," sued Thomas Swartwout for ninety florins for the purchase of 102 planks. $^{31}$

Despite seventeenth-century Dutch law that stated,

"Conversely, a married woman may not appear in court except as authorized by her husband; may not alienate or encumber her husband's property or her own; may not contract debts to bind herself or her husband ... “ 632

${ }^{28}$ Ibid., 297.

${ }^{29}$ Ibid., 2: 60.

${ }^{30}$ Ibid., 64.

${ }^{31}$ Ibid., 3: 194.

${ }^{32}$ Grotius, The Jurisprudence of Holland, 29-31. 
among the thousands of cases in the New Netherland records, only these four in some fashion mention a husband's procuration to his wife to act in his behalf. Grotius indicated this section of the law was militated by the commercial acceleration of the Dutch economy. Specifically, he related wives' domestic authority to trade items of a household nature was expanded during the commercial revolution to include contracting, "in all matters relating thereto (public commerce)." ${ }^{33}$ Therefore, laws that required husbands' authority for wives to act in their place were anachronisms. That helps to explain why their application rarely occurred in New Netherland.

Dutch wives' authority to act in their husbands' behalf in court was not the only variation from traditional characterizations of early American patriarchy. Another measure of patriarchy used by historians of early American women was male control of the sexual activity of women within the household, including wife, daughters, and dependent female servants. ${ }^{34}$ When the paterfamilias was unable to control the sexual behavior of the women in his household, the state could and sometimes did, intervene. ${ }^{35}$ Regulation of the sexual behavior of females by males reinforced the hierarchical structure of the male dominated state. ${ }^{36}$

An important aspect of controlling women's sexual behavior was domesticity,

${ }^{33}$ Ibid., 31.

${ }^{34}$ Brown, Good Wives, Nasty Wenches, and Anxious Patriarchs, 4.

${ }^{35}$ Norton, "The Government of Familyes," Founding Mothers and Fathers, prologue: $27-56$.

${ }^{36}$ Brown, Good Wives, Nasty Wenches, and Anxious Patriarchs, 15-17, 91-94. 
i.e., staying close to the hearth. Husbands did not closely monitor the comings and goings of most wives unless they had reason to question their fidelity. However, with notable exceptions, among the English in America, being absent from their families for extended periods was unusual for wives. ${ }^{37}$

The responsibilities of domesticity among Dutch wives were no less significant and perhaps more significant for the welfare of their families. Beyond the duties commonly associated with marriage and motherhood many wives were responsible for managing the family purse. The obligations of domesticity were sometimes antithetical to responsibilities associated with managing accounts. Many wives balanced opposing obligations by corresponding their requirements to people who, owing to business relationship or affinity, acted for them. The examples of Maria van Rensselaer and Margaret Hardenbroeck are well known to historians of the seventeenth-century Dutch in America. ${ }^{38}$ However, non elite wives also relied on correspondence to manage accounts. For example, in November 1655, the wife of Cornelis Teunissen, who was not named in the record, represented her husband in a suit against him by Cornelis van

\footnotetext{
${ }^{37}$ Those exceptions included midwives who, particularly during difficult deliveries, were sometimes required to attend their patients for several days. Ulrich, "Martha Ballard and Her Girls," in Steven Innes, ed. Labor and Early America (New York,1988), 70-105; A Midwife's Tale: The Life of Martha Ballard, Based on Her Diary, 1785-1812 (New York, 1990).

${ }^{38}$ CMVR; Christoph, “"Worthy, Virtuous Juffrow Maria van Rensselaer”; Dankaerts and Sluyter, Journal of a Voyage to New York; Mary L. Booth, History of the City of New York From Its Earliest Settlement to the Present Time (New York, 1859), 829; Jean P. Jordan, "Women Merchants in Colonial New York," New York History (October, 1977), 412-439: 418; Biemer, "Margaret Hardenbroeck: Merchant, Shipowner, Supercargo," Women and Property, chapter 3, 33-43: 41; Ritchie, The Duke' Province, 59, 121.
} 
Ruyven. Van Ruyven demanded fl300 plus interest for two oxen. Teunissen's wife reported receiving, "a letter from Holland from her friends, whereby her own inheritance belongs to her, and that pltf. has those letters." 39 Van Ruyven demanded the oxen be turned over to him, but that, “in consideration of the deft's lose circumstances, to give her fl40 to make an even sum." $" 40$

However, when Dutch wives found it necessary to attend to matters personally over extended periods, they were not prevented from doing so by any social reasons. Wives traveling to distant places like Holland or to other colonies may have been considered an extension of their responsibilities for managing the financial affairs of their families. Owing to the Journal of Jasper Dankaerts and the Philipse Papers at Historic Hudson Valley, Margaret Hardenbroeck's travels are well known to historians of New Netherland and early New York. ${ }^{41}$ However, her elite status afforded opportunities that may not have been available to women of lesser means.

Extended travel by non elite women in New Netherland rarely mirrored that of Margaret Hardenbroeck. However, records affirm Dutch society in America accepted wives' absences from their families. Jan Harmensen did not reveal why his wife had traveled to the Netherlands. ${ }^{42}$ Owing to the couple's non elite status, the reason must have been compelling. Perhaps it was to attend to family members back home. Perhaps

\footnotetext{
${ }^{39} R N A$, I: 406.

${ }^{40}$ Ibid., 407.

${ }^{41}$ Dankaerts and Sluyter, Journal of a Voyage to New York.

${ }^{42} R N A$, I: 147.
} 
the death of a parent required her presence to help with probate. Another reason may have been to attend to trade. At the same session of the Burgomasters and Schepens court in which Jan Harmensen appeared, Cristina Capoens, wife of Jacob Haey was the defendant in another debt litigation case. ${ }^{43}$ Jacobus Vis sued her for payment of 1128 pounds of tobacco. Capoens maintained she made the obligation in Virginia and was only obligated to pay there. She further revealed, "the time is such, that she has not been able to go thither to make the payment there.; it is therefore no fault of hers that it has not been made."44

Particularly revealing about Capoens' case was that she did not involve her husband and she assumed responsibility for the debt, including the requirement of traveling to Virginia. After appointing arbiters to settle the case, the court added the provision that litigants could not continue it until the return of the defendant's husband. ${ }^{45}$ However, it is clear Capoens was in command of the account in question and her husband's appearance served to establish joint legal responsibility for the debt. Capoens' assumption of personal responsibility infers unusual decision making authority within her family.

If Capoens' appearance was a single example or, one of few, in the records of Dutch wives' decision making authority within their families, her action would not be

${ }^{43}$ January 12, 1654. Ibid., 148.

${ }^{44} \mathrm{Ibid}$. The case was turned over to arbiters who were commanded to resolve the difference between the litigants or report their opinion to the court if resolution proved impossible.

\footnotetext{
${ }^{45}$ Ibid.
} 
significant. However, hers was one of many similar expressions of authority exerted by wives. Owing to marital dysfunction and eventual separation, a particularly interesting case was that of Nicolaes Boot against the wife of Louren Jansen in March 1656. The suit involved a debt of fl28.15. Jansen's wife acknowledged the debt, but claimed the amount was fl12, owing to payments already paid to Boot's wife, Merritje Joris. Boot denied payment had been made to his wife and demanded proof from Jansen's wife. The court mandated Jansen's wife to produce proof she paid Marritje Joris. ${ }^{46}$

Two factors tempt the conclusion that a struggle for authority occurred between Nicolaes Boot and Merritje Joris. First, Boot did not petition the court again for the money, which infers Jansen's wife produced the proof required by the court. Second, the record of marital dysfunction between Boot and Joris began not long after this suit, in April 1658. Specifically, their relationship deteriorated to the point Joris requested a separation from her husband. ${ }^{47}$ If Joris came to the decision to seek a legal separation after a long instance of marital discord, she and Boot were likely living under strained conditions in 1656. As a merchant-trader, Boot often depended on Joris to attend business affairs at home, including maintenance of accounts. Therefore, by not revealing details about specific accounts, Joris used her position and knowledge to exert power in her marriage.

Beyond a struggle for authority within the Boot and Joris marriage, Boot's suit against the wife of Louren Jansen subtly indicated existence of powerful relationships

\footnotetext{
${ }^{46}$ Ibid., 2: 67.

${ }^{47}$ Ibid., 374.
} 
among women in the colony. While Nicolaes Boot was the plaintiff in the suit, it was the financial relationship between Joris and Louren Jansen's wife that created the need for it. Owing to wives' management of many family and business accounts in New Netherland, women collectively influenced the economy of New Netherland. Wives' financial decision making authority did not necessarily always occur without their husbands' knowledge. Nevertheless, since many wives assumed responsibility for keeping ledgers and paying bills, collectively they exercised considerable power in New Netherland.

In addition to civil litigation, there were other indications in public records of wives' exercise of power through financial decision making. For example, in October 1655, the director-general and his council authorized a collection for building physical barriers to ward off Indian attacks. The collection was voluntary, but, "in case of opposition or refusal by disaffected or evil minded, [the director-general authorized the Burgomasters and Schepens] to assess such and according to the state and conditions of the same to exact a reasonable contribution. ..."48 Four women, all of whom were referred to as wives, e.g., "Michel Poulisen's wife," were among the contributors. ${ }^{49}$ Three of the women voluntarily contributed varying amounts ranging from ten to twenty florins. They assessed only one woman, Teunis the mason's wife, who volunteered to pay five florins, but was assessed to pay six. ${ }^{50}$

\footnotetext{
${ }^{48}$ Ibid., I: 366.

${ }^{49}$ Ibid., 370.

${ }^{50}$ Ibid., 370-373.
} 
Therefore, the financial decision making authority of wives shaped economic activity in New Netherland. However, although wives were an economically powerful force in aggregate, power was fragmented owing to their priorities. Specifically, the priority for most women was their family. A series of debt litigation cases initiated by Cornelia Schellinger in 1656 illustrates the intimate relationship between family and women's power. When Cornelia Schellinger sued three other women, including Annetie Smith, Tryntie Heymans, and Tryntie van Hengelen, on February 28, 1656, the recorder identified her as the wife of Jacob Schellinger. However, when she sued Adriaen Keysar, she did so under her own name. ${ }^{51}$ The difference is subtle and may only be owing to the style of the recorder. Regardless, the variance illustrates a dichotomy in women's exercise of power. Specifically, women's exercise of power was an accepted feature of seventeenth-century Dutch culture and the vast majority of women exercised power for the benefit of their families. As I will show, it was not until the extraordinary events of Leisler's Rebellion and his subsequent fall that women turned their network into a force for political change. However, even during Leisler's Rebellion, women's unity was fragmented along family lines that corresponded to the political landscape.

The intimate relationship between self-actualization and the importance of family and lineage in Dutch culture explains why Dutch women focused their uncommon power on their families. Like most women in the seventeenth-century,

\footnotetext{
${ }^{51}$ Ibid., 48-49.
} 
Dutch women found identity through their roles as wives and mothers. ${ }^{52}$ It is no coincidence that Dutch law reinforced identification with the family by defining women's power through marriage and family. Women were legally defined as subordinate to their husbands, but many of those laws were medieval anachronisms in the early-modern exponential commercial growth of the Netherlands. ${ }^{53}$ This was particularly the circumstance in New Netherland where the life of the colony was dependent on commerce. However, commerce was not the only reason the law and social practice were incongruent.

An entry in the court of Beverwijck records for the power of attorney granted by Hans Coenraetsen to his wife, Barentge Straetskereke, illustrates the conflict between present circumstances and medieval laws governing the authority of wives. Coenraetsz sailed for the West India Company as a cadet. His long absences required someone to act for him, including collecting his pay from the director-general and attending to his financial obligations. However, rather than limit his wife to only these duties, he granted her extraordinary authority to act. The notarized instructions also included prerogative,

${ }^{52}$ Sherrin Marshall, "The Core Family Unit and the Lineage: Identity, Relations, and Realities," (New York, 1987), chapter one: 1-12.

${ }^{53}$ Grotius, The Jurisprudence of Holland, 29-33. Historians will continue to debate the patriarchal conservatism of Dutch laws and the relative legal power of seventeenth-century Dutch women. See, for example, Biemer, Women and Property; Firth Haring Fabend, A Dutch Family in the Middle Colonies, 1660-1800 (New Brunswick, 1991); Narrett, Inheritance and Family Life; Shattuck, "A Civil Society,"chapter three; Adriana E. van Zwieten, “'[O]n her woman's troth': Tolerance, Custom, and the Women of New Netherland," de Halve Maen, (Spring, 1999), 3-14. 
"to execute and furthermore all things to do, perform and transact which may be needful and which she may deem advisable; [the principal] promising at all times to ratify without contradiction whatever his said wife in the matter aforesaid shall do and perform."54

Grotius' assertion that,

"the commerce and wealth of the country being greatly increased, the principle [of allowing wives control over domestic production and property] was extended, so that, to-day, a married woman, engaged in public commerce or trade, may contract in all matters relating thereto, and consequently may bind herself and her husband ...,",55

implies extraordinary power for wives to act independently and infers marriage was a partnership. However, it was in contrast to Grotius' further contention, "the female sex is generally colder and more moody than the male sex, and less fitted for affairs which require understanding: therefore the male sex is given by nature a sort of authority over women." 56 From which husbands were considered the head of the family with exclusive authority over family property. Grotius also made a Filmer-like analogy between the hierarchy of the family and the hierarchy of the state. ${ }^{57}$ Therefore, the seventeenthcentury Dutch were in the throes of transition. In some respects they held to the security of the past, but experienced too much prosperity from commercial capitalism to redefine

${ }^{54} E R A, 3: 34$.

${ }^{55}$ Grotius, The Jurisprudence of Holland, 31.

${ }^{56}$ Ibid., 15-17.

${ }^{57}$ Ibid., 15, 29-31; Katherine A. Lynch, "The Family and the History of Public Life," Journal of Interdisciplinary History (1994), 665-684. Robert Filmer, Patriarcha and Other Political Works, Peter Laslett, ed. (Oxford, 1949). 
the parameters of their cultural quintessence.

Legally, wives were the partners of their husbands, but they were not full partners. However, a gap existed between Dutch law and Dutch culture that enabled wives to advance their own and their families' interests without suffering reproof for stepping beyond patriarchal limits. ${ }^{58}$ That is, legal sanctions were available and sometimes applied, but most Dutch husbands placed as much confidence in their wives as did Hans Coenraetsen. This implies husbands "allowed" their wives' independence, which is contradictory. However, another perspective is, Dutch law recognized marriage as a partnership that limited the absolute authority of husbands in ways the legal codes of many other European countries, particularly England, did not. That is, through specific exceptions, Dutch marriage laws mitigated the severity of patriarchal conservatism. Rapidly advancing commercial wealth, humanism, and religious reformation made unlimited patriarchal authority, if it ever existed, insufficient to meet the needs of early modern Dutch society.

However, this begs the question, did the power of Dutch women derive from their domesticity, which some authors characterize as an ill-defined but decidedly subordinate position $?^{59}$ The answer is more complex than assigning a theory of gender-

\footnotetext{
${ }^{58}$ Most authors of New Netherland and seventeenth-century American Dutch history link Dutch law and Dutch culture. See, for example, David William Voorhees, "'how ther poor wives do, and are delt with': Women in Leisler's Revolt," de Halve Maen, vol.lxx, no.2 (Summer, 1997), 41-48: 41. However, as I have shown, Dutch law was in many ways antiquated with medieval patriarchal conservatism ill-suited for a commercial economy.

${ }^{59}$ Norton, Founding Mothers and Fathers, 8; Cowen, More Work for Mother, 7; Brown, Good Wives, Nasty Wenches, and Anxious Patriarchs, 14; Sarah F. McMahon,
} 
based power that begins in the family and progresses to the state and religious institutions. ${ }^{60}$ Sociologically, power has traditionally been associated with dominance. ${ }^{61}$ An often overlooked but important characteristic of power is responsibility. Specifically, it is taking responsibility for the consequences of decision making.

No historian of early American women has denied women overall and wives in particular had significant responsibilities that ensured the maintenance of their families. Although many historians have recognized the non-domestic duties of women, for most historians domesticity was their defining characteristic. ${ }^{62}$ Decision making about domestic labor by wives was no less complex than that of husbands who more often represented their families in public arenas. Furthermore, decision making in domestic responsibilities was equally as important to family maintenance as other decisions. After all, a family that didn't have a member knowledgeable about food preservation might starve in the onslaught of winter.

However, wives in English colonies were no more responsible for the consequences of their decisions than their husbands and the law allowed. Their legal

"Laying Food By: Gender, Dietary Decisions, and the Technology of Food Preservation in New England Households," McGaw, ed. Early American Technology, 164-196: 168.

${ }^{60}$ Brown, Good Wives, Nasty Wenches, and Anxious Patriarchs, 15-17.

${ }^{61}$ Catherine MacKinnon, Feminism Unmodified: Discourses on Life and Law (Cambridge, MA., 1987), 40; Abigail J. Stewart, "Toward a Feminist Strategy for Studying Women's Lives," in Carol E. Franz and Abigail J. Stewart, eds. Women Creating Lives: Identities, Resilience, and Resistance (Boulder, CO., 1994), 11-35: 25.

${ }^{62}$ De Hart and Kerber, "Gender and the New Women's History," Women's America, introduction: 3-23. 
incapacities, particularly in regard to absence of independent status, i.e., femme covert, limited their personal liability in most civil litigation cases. ${ }^{63}$ Dutch law limited the liability of wives in a similar fashion in that wives were considered sub tutela, i.e., under the guardianship of their husbands. However, under Dutch law the community property feature of marriage combined with the cultural phenomenon of assigning extraordinary responsibilities to wives to cause their decision making to affect themselves, their families, and others. Extending the quote on page 184, in the language of Grotius, a wife,

"may contract in all matters relating thereto (trade), and consequently may bind herself and her husband, and alienate and encumber her stock. All other women may only make contracts relating to household affairs, and so far bind themselves and their husbands: a husband cannot prevent this, unless at the same time he forbids his wife by legal process to exercise this function, and causes the same to be proclaimed: but in every case, beside what has been said above, the husband may be sued so far as he may have been enriched by his wife's contract." ${ }^{, 64}$

In order for the commercial economy of the seventeenth-century Netherlands and New Netherland to function efficiently, Dutch marriages were partnerships in theory and practice. In defining husbands' authority over community property, Grotius earlier maintained, "If the husband contracts in debts from any cause whatever, the wife too is bound by them without her consent.." ${ }^{05}$ Therefore, Dutch marriages functioned as a

\footnotetext{
${ }^{63}$ Salmon, Women and the Law of Property, 14-15; Friedman, A History of American Law, 208-209.

${ }^{64}$ Grotius, Jurisprudence of Holland, 31.

${ }^{65}$ Ibid., 29.
} 
unit. Husbands exercised limited legal authority over the non domestic activities of their wives. Nevertheless, the flexibility of Dutch law enabled wives to make contracts for which their husbands were liable.

Marital partnership and wives' participation in the commerce required Dutch women to assume greater responsibility for the consequences of their decisions than experienced by most women in early America. Owing to marital partnership, wise decisions enriched them and poor decisions encumbered them. Moreover, their decisions affected their families, other people, and consequently, the economic vitality of New Netherland and seventeenth-century New York. Most wives wielded their decision making authority carefully in order to protect the financial future for themselves and their families. They often did so to the point of self sacrifice. The detailed efforts of Maria van Rensselaer to save Rensselaerswijck for her son and other progeny while she experienced overwhelming personal hardship is recounted elsewhere here and by Peter Christoph. ${ }^{66}$ Owing to her elite status and the far reaching effects of her decisions, van Rensselaer is well known to historians of early New York. However, although her level of responsibility was unique among Dutch women in New Netherland and seventeenth-century New York, the experience of responsibility for decision making was not. Many non elite women with fewer resources than van Rensselaer were equally assiduous in assumption of responsibilities that affected them and their families.

Three debt litigation cases randomly selected from the 1663 Kingston Court

${ }^{66}$ See, "More Than Deputy-Husbands," and "Women and the Colonial Economy," (tentatively chapters 2 and 3); Christoph, “'Worthy, Virtuous Juffrow Maria van Rensselaer'." 
records illustrate the significance of decision making by women to themselves, their families, and formal structures like law and economics.

On January 29, Hester Douwens sued Tjirck Classen deWit for fl300.18 in sewant for goods and jewelry purchased by the defendant. DeWit maintained he settled the account verbally with Douwens in the presence of her husband and that the balance was not so much. He maintained he owed only, "twenty-six schepels of wheat, a schepel of onions, and a half a thousand bricks." ${ }^{97}$ The court had little interest in the declaration of a verbal settlement without proof. Nevertheless, in fairness to the defendant the magistrates delayed action for fourteen days in order for deWit to present a counter bill or proof (witnesses?) he already settled with Douwens. ${ }^{68}$ Three weeks later the litigants reached a private settlement that included the wheat and bricks and 3.5 florins. ${ }^{69}$

In May 1663, Hendrick Jochemsen sued Geertruyt Andrissen for an unrecorded amount owing from her late husband, Jacob Jansen Stol. Andrissen accepted responsibility for the debt, but informed the court she would like to examine her husband's books to determine the validity. As in the circumstance of Tjirck Classen deWit, the magistrates allowed Andrissen fourteen days to examine her husband's books and reach a settlement with Jochemsen. ${ }^{70}$ The absence of further action in the

\footnotetext{
${ }^{67}$ Kingston Papers, I: 56-57.

${ }^{68}$ Ibid., 57.

${ }^{69}$ Ibid., 61.

${ }^{70}$ Ibid., 69-70.
} 
case indicates Andrissen may have privately settled with Jochemsen.

The last illustration is a case in which Gysbert van Imbroch sued Annetje Ariaens, "wife of Aert Pietersen Tack."71 Van Imbroch wanted to be paid before any of Ariaens other creditors and requested a court order to prevent alienation of her grain crop to others. Ariaens retorted if van Imbroch, "will undertake to pay her debts [including those contracted to feed her family during the harvest] she will then get out and leave." 72

Individually, these three debt litigation cases are not important. Their greatest significance is their similarity with many other debt litigation cases involving women in the records of New Netherland. Collectively, these and other cases involving women reveal their exercise of power. First, Dutch society in America accepted their authority to make legal decisions affecting their families and therefore the colonial economy. Legal liability for the consequences of decision making reinforced acceptance of their authority and provided a formal structure for accountability. When Annetje Ariaens responded to van Imbroch's demand for payment, her sentiments were common to all who have the responsibility for debts without the resources to pay them. Besides telling van Imbroch if he would pay her debts she would "get out and leave," she explained she had borrowed to buy food during the harvest, "otherwise she could not have taken in the crops." 73 The latter information may have been more for the magistrates than for van

\footnotetext{
${ }^{71}$ Ibid., 91-92.

${ }^{72}$ Ibid., 91.

${ }^{73}$ Ibid., 91-92.
} 
Imbroch. She expressed a sense of overwhelming helplessness at her inability to make ends meet. Her only recourse was to tell her tale of woe in the hope it would generate enough sympathy to generate a reprieve from the court. However, the magistrates were notorious for upholding the legal foundations of a debt-credit economy. The court was emphatic in its decision. Ariaens was ordered, "not [to] appropriate or decrease, much less alienate, any of the grain." 74

The Ariaens case illustrates wives were accountable for the decisions made in a public arena, i.e., commercial enterprise. However, cases like the Douwens' suit against Tjirck Classen deWit shows the legal system supported wives' decision making authority when wives were attentive to laws that governed commerce. In a colony founded to make profits from commerce and maintained owing to the presence of a population largely involved in trade, rules of commerce were vital. Being a woman had nothing to do with Margaret Hardenbroeck's success as a merchant-trader. Her success at commerce came from an astute business sense, attention to contractual law, and a cultural heritage that promoted wives' participation in trade.

While anachronisms like husbands' restriction of wives' decision making authority existed under Dutch law, only one husband in the records of New Netherland exercised it, the previously mentioned Claes van den Bergh of Fort Orange. ${ }^{75}$ Perhaps so few challenged their wives owing to advantages that accrued from their wives' participation in trade. The story of Frederick Philipse (Flipsen), who came to New

\footnotetext{
${ }^{74}$ Ibid., 92.

${ }^{75}$ see p. 8.
} 
Netherland as a ship's carpenter and became the second husband of Margaret

Hardenbroeck and was thereby enriched is well known. ${ }^{76}$ However, elite status was not a prerequisite for husbands to enjoy enrichment by their wives commercial activity.

While commercial activity by non elite wives often appears trivial in comparison to those of women like Margaret Hardenbroeck, it establishes a historical pattern of sharing responsibility for decision making between Dutch wives and husbands. Wives' commercial activity was often a consequence of their husband's labor. For example, in April 1654, the wife of Teunis Tomasen sued Michiel Paulisen for fl13. "due her for a chimney, built by her husband."77 Similarly, in November 1655, the wife of Andries Jochemsen sued Pieter Jansen for, " 18 gl[uiders] or 150 sticks of firewood for wages earned four years ago." ${ }^{.78}$ Did she make the decision to accept firewood in lieu of specie? With winter approaching it was likely the more prudent choice.

\footnotetext{
${ }^{76}$ One of the earliest historians to recognize Hardenbroeck's contribution to the Philipse legacy was Mary L. Booth, History of the City of New York From Its Earliest Settlement to the Present Time (New York, 1859), 859. However, although Booth maintained Hardenbroeck, "possessed remarkable energy and practical talent," she couldn't resist associating the beginning of Frederick Philipse's financial success with Pieter Rudolphus, Hardenbroeck's first husband, "to whose business he succeeded." More recently, Linda Biemer, "Margaret Hardenbroeck: Merchant, Shipowner, Supercargo," Women and Property in Colonial New York, chapter 3:33-43, attributed Philipse's advancement to his marriage with Hardenbroeck, but similarly implies Rudolphus was the foundation of her wealth. [34] Based on the record of taxes paid by Rudophus in 1655, I maintain the business acumen she brought to both marriages was an important contributor to the prosperity of both men. David T. Valentine, "Tax and Contribution List," History of the City of New York (New York, 1853), appendix: 315317; Gherke, "Margaret Philipse: New York Merchant," (unpublished paper, West Virginia University History Forum, 1997), 7-10.

${ }^{77} R N A$, I: 188 .

${ }^{78}$ Ibid., 410.
} 
The records of New Netherland are replete with similar examples of decision making by wives that, at least on the familial level, had profound importance. More significantly for the historiography of early American women, there is little indication among the Dutch of a dynamic tension based on gender that presumes much of the writing about seventeenth-century American women. ${ }^{79}$ Partnership in marriage among the Dutch was achieved by developing a practical relationship of reciprocal responsibilities and opportunities, i.e., authority, in which wives were coequal. Inasmuch as the family was the foundation of early-modern Dutch society, many Dutch women learned about the responsibilities of authority at an early age and through experience exercised it wisely through marriage and widowhood. ${ }^{80}$

One of the problems with much of the historiography of seventeenth-century America and early American women in particular is the focus on English culture to the marginalization of other cultures. ${ }^{81}$ In addition, with the exception of historians like Richard Morris, Julia Cherry Spruill, Laurel Thatcher Ulrich, and a few others, the historiography of early American women has focused on narrowly defined social models. English defined gender as an expression of patriarchal conservatism has been

\footnotetext{
${ }^{79}$ Norton, Founding Mothers and Fathers, 4; see also, Brown, Good Wives, Nasty Wenches, and Anxious Patriarchs.

${ }^{80}$ Sherrin Marshall, The Dutch Gentry, 1500-1650: Family, Faith, and Fortune (New York, 1987), 2; A.M. van der Woude, "Variations in the size and structure of the household in the United Provinces of the Netherlands in the seventeenth and eighteenth centuries," 301; Schama, Embarrassment of Riches, 425; Van Deursen, Plain Lives in a Golden Age, 84-95.

${ }^{81}$ Joyce D. Goodfriend, "Writing/Righting Dutch Colonial History,” New York History, vol. 1xxx, no. 1 (Jan., 1999), 5-28: 6.
} 
one of them. Kathleen Brown tied ascendance of conservative English patriarchy and institutionalization of slavery with the fallout of Bacon's Rebellion in Virginia. ${ }^{82}$ The subtitle of Mary Beth Norton's most recent work, Founding Mothers and Fathers: Gendered Power and the Forming of American Society, reveals her premise that power was gendered in seventeenth-century America. However, the title is misleading. She indicates in the introduction that her focus is, "on the first-half century of English colonization in North America." 83

Social constructs of feminist historians like Brown and Norton are useful and important for studying the historical context of the lives of the majority of early American women. However, as Abigail J. Stewart maintains, one the characteristics of feminist strategy for studying women's history is resisting acceptable subjects for inquiry. ${ }^{84}$ Therefore, early American Dutch women and the uncommon cultural characteristics that help us understand them should not be considered mere anomalies to accepted models of early American life. More specifically, the Dutch concepts of reciprocity for responsibilities within marriage and the significance of decision making by wives contribute to the multi-cultural patchwork of early American women's lives. An example of the importance of Dutch wives and their expressions of power

${ }^{82}$ Brown, Good Wives, Nasty Wenches, and Anxious Patriarchs, 4.

${ }^{83}$ Norton, Founding Mothers and Fathers, 4 . The title implies the work is inclusive of different in early America. However, the work is exclusively about English culture in early America.

${ }^{84}$ Stewart, "Toward a Feminist Strategy," 13. 
within Dutch culture is evident in women's participation in Leisler's Revolt. ${ }^{85}$ Particularly after 1674, when the English acquired uncontested possession of New Netherland by treaty, factionalism developed among the New York Dutch population. The development of factions goes to the heart of the historiographic debate about the causes of Leisler's Rebellion. Specifically, there were many among the commercial elite who resisted what they considered Leisler's pretensions in assuming leadership of the colony. They had successfully adapted to political and legal changes consequent from the English acquisition of New Netherland and the Leisler faction represented a threat to the new order. ${ }^{86}$

Women who participated in the political events surrounding Leisler's Rebellion followed patterns of behavior similar to that of their mothers and grandmothers. There was a long tradition of popular revolt involving women in the Netherlands. Women often led seventeenth-century food riots, or oproar, in the Netherlands. At least two authors maintain European women were identified with food riots owing to the intimacy of their relationship with cooking. ${ }^{87}$ Specifically, rising food prices affected them

${ }^{85}$ Voorhees, “"how ther poor wives do, and are delt with.”

${ }^{86}$ Maika, "Commerce and Community," (Ph.D. dissertation, NYU, 1995), 502; David William Voorhees, "'In Behalf of the true Protestants religion:' the Glorious Revolution in New York," (Ph.D. dissertation, NYU, 1988); Murrin, "English Rights as Ethnic Aggression," 64.

${ }^{87}$ Olwen Hufton, "Women in Revolution, 1789-1796," Past and Present, no. 53 (1971), 90-108: 95; Rudolf M. Deker, "Women in Revolt: Popular Protest and Its Social Basis in Holland in the Seventeenth and Eighteenth Centuries," Theory and Society, vol. 16, no. 3 (May, 1987), 337-362: 341. 
through their connection with consumption. ${ }^{88}$ Their immediate concern was feeding their children. Psychologically, inability to feed their families affected selfidentification with their roles as wives and mothers.

However, more than lack of food brought Dutch women to the streets in protest. In addition to food riots, women participated in and sometimes lead popular protests against new taxation and political changes. ${ }^{89}$ Rudolf Deker has explored different theories about why women often joined popular protests; including the theories the authorities were less likely to prosecute women, that women found personal satisfaction in taking measures into their own hands, and were more likely to protest when the reasons for the protests negatively affected their domestic roles. ${ }^{90}$

While popular uprisings and women's involvement in them occurred with regularity in the seventeenth and eighteenth centuries in the Netherlands, they were the result of extraordinary circumstances. For example, the Organist riot of 1653 was precipitated by the death of William II in 1650 and a resultant struggle for power between centralized power and the anti-Organists. ${ }^{91}$ Similarly, in 1672 women took to the streets in the Organist revolts in Holland and Zeeland. ${ }^{92}$

Women did not hold political office or formally make decisions affecting

\footnotetext{
${ }^{88}$ Sheila Rowbotham, Hidden from History (London, 1973), 26.

${ }^{89}$ Deker, "Women in Revolt," 340.

${ }^{90}$ Ibid., 337-346.

${ }^{91}$ Schama, The Embarrassment of Riches, 65; Deker, "Women in Revolt," 340. ${ }^{92}$ Ibid.
} 
matters of state. However, they were staunch defenders of their families and friends. As I have shown through civil suits, many wives managed income and expenses for their families and were fierce competitors in court when family financial interests were threatened. In their management of financial affairs and more so in their domestic roles as wives and mothers they helped create the order by which their society lived. Therefore, it is not surprising they were equally fierce when political instability threatened that order.

Women established order through networks of family and neighbors. In that regard, wives's participation in the events of Leisler's Rebellion was consistent with others in which Dutch women were involved. Particularly anti-Leislerian wives were not interested in the maintaining the pre-Leisler political status quo except insofar as that arrangement insured maintenance of networks based on family and status. Specifically, anti-Leislerian women were obstreperously resistant to Leisler's threats to the social and economic order they helped create, maintain, and through which they accomplished their goals. In essence, Leisler's Rebellion threatened their power.

Therefore, women's involvement in Leisler's Rebellion did not represent crystallization of ethnic or gender issues. Particularly women who opposed Leisler did so as the wives of anti-Leisler husbands and families. ${ }^{93}$ However, the scattered records that indicate their participation in events show women's actions were usually

${ }^{93}$ For that reason, the records indicate women were unequivocally involved in the events between 1689 and 1691, but seldom were their actions overt enough to be included in the public record. 
spontaneous rather than calculated..$^{94}$ For example, in 1689 Nicholas Bayard, who was an avowed enemy of Leisler, reported he escaped bodily harm and perhaps even death when a, "multitude of armed men, striking and beating against the door, threatening by swords and fire armes to force open s[aid] door.. ${ }^{95}$ Bayard included an addendum that noted, "Trijn Jans the wife of Jan Joost was very active in this ffurie."

A woman's precipitate decision made in the passion of the moment may have also been behind the mutilation of Leisler's body following his execution in May 1691 . According to one report, a woman requested Leisler's heart and for a reward the executioner obliged her. The validity of this rumor cannot be ascertained to a historian's satisfaction, but Leisler's body was mutilated after his execution. ${ }^{97}$ The woman was reportedly Judith [Judick] Verleth, wife of Nicolas Bayard. The veracity of the account is less important than what it implies. It reveals women involved in the events sometimes reacted passionately to what they perceived as personal affronts.

Prior to Leisler's Rebellion women in New Netherland were not reluctant to physically assault their neighbors, spouses, and others for perceived insults, defamations, and out of positions of authority. For example, in April 1656, Nicholas Boot purchased a female slave from Alexander d'Inoyoseph. Prior to delivery of the

${ }^{94}$ Voorhees, “"how ther poor wives do, and are delt with'," 41.

${ }^{95}$ quote, $N Y C D$, 3: 603; for the foundation of Bayard's animosity toward Leisler, see Charles M. Andrews, ed. "A Modest and Impartial Narrative," Narratives of the Insurrections, 1675-1690 (New York, 1915), introduction: 317-318

${ }^{96} N Y C D, 3: 604$.

${ }^{97}$ Voorhees, "“how ther poor wives do, and are delt with',"41. 
slave to Boot she was apparently beaten to the degree she was no longer able to work and Boot sued for financial restitution. The magistrates ruled, "Boot is bound to receive back the said negress, on condition that d'Inoyossef shall prove, that the negress has received no injury by being beaten by his wife." 98 Owing to absence of further litigation in this case it is assumed the slave recovered.

In May 1658, Barent Egbersen and his wife (unnamed) and Jan Smedinck and his wife (also unnamed) occupied different halves of the same house. Smedinck and his wife rented their half of the house from Egbersen. Different families occupying halves of the same house was not an unusual arrangement in New Netherland. ${ }^{99}$ However, these families could not get along and complained of each other to Schout Nicasius de Sille that their neighbors, "kept a disorderly house and beat each other."100 Barent Egbersen further stated, "that the women had words together and that his wife struck Jan Smedincks wife on the back, but that Jan Smedincks wife struck his wife more severely and Jan Smedinck also; and that his wife is near her time."101 The magistrates ordered Smedinck and his wife to vacate the house, but insisted Smedinck pay the remaining amount owed for rent. ${ }^{102}$

More interesting in relation to Leisler's Rebellion is the record of Judith [Judick]

${ }^{98} R N A, 2: 88$.

${ }^{99}$ Cohen, The Dutch American Farm.

${ }^{100}$ Ibid., 376.

${ }^{101}$ Ibid.

${ }^{102}$ Ibid. 
Verleth's past record in court. Verleth demonstrated a proclivity for physical violence long before the events of Leisler's Rebellion. As early as June 1655 she was brought to court by Wolfert Webber who sued her for assault. Webber complained, "of violence, force and abuse committed against him by (Verleth) and her sister, Sarah, last week in his house; striking him, in his own house and flinging stones at him.” Verleth countered with accusations that Webber called her a whore and struck her and her sister. The court ordered both parties to present evidence of their accusations at a later session, but there is no record Webber followed up with his litigation. ${ }^{103}$

If the reports about the mutilation of Leisler's body in 1691 are correct and Verleth participated, she had not lost her predilection for violence. Indeed, she achieved a new level of barbarism. However, much had occurred in the intervening years to bring about her reaction. As the wife of Nicolas Bayard she was involved in the Loockermans' feud that pitted Leisler and his wife, Elsie Tymens, against Bayard and others connected by blood and marriage to the New York oligarchy that had developed in the latter half of the seventeenth century. ${ }^{104}$ Leisler represented his wife's mother's, Maria Loockermans, interests after the death of her third husband, Govert Loockermans. ${ }^{105}$ Elsie Tymens was the daughter of Tymens Jansen, Maria's first husband, and perhaps because he died intestate, Elsie's patrimony was not settled prior

${ }^{103}$ Ibid., I: 326.

${ }^{104}$ Fabend, “'According to Holland Custome': Jacob Leisler and the Loockermans Estate Feud," De Halve Maen, vol. 67, no. 1 (Spring, 1994), 1-8: 3.

${ }^{105} R N A, 7: 99,103-104$. Leisler also represented Jacob Loockermans, son of Govert. Fabend, “'According to Holland Custome'," 6. 
to Maria's subsequent marriages to Dirck Cornelissen and Govert Loockermans. When Leisler began to unravel the convoluted condition of Maria Loockermans' estate following the death of Govert, he sought the greatest advantage for his wife's patrimony. ${ }^{106}$

Owing to their personal hatred of Leisler, Bayard and his wife, Judith Verleth, needed little encouragement to condemn his assumption of authority. ${ }^{107}$ However, they are representative of the fractures that had occurred in New York Dutch society as a result of English acquisition of New Netherland. Linda Biemer and others have commented on the particular assault on married Dutch women's legal ability to act in partnership with their husbands. ${ }^{108}$ The Glorious Revolution that brought William and Mary to the throne in 1688 came during a period of financial hardship that exacerbated factionalism. ${ }^{109}$ Combined with fears of attack from the French or Indians, the colony was ripe for political unrest. Lieutenant Governor Francis Nicholson reported on the

${ }^{106}$ Fabend, "“According to Holland Custome'," 6. Leisler is portrayed by Fabend as a shrewd manipulator of unique circumstances. Depending on specific circumstances, Leisler applied English or Dutch inheritance practice to secure the greatest advantage for his wife from the Loockermans estate.

${ }^{107}$ Bayard's personal animosity toward Leisler is evident in all of his correspondence about Leisler's administration. See for example, "Colonel Bayard to Sir Edmund Andros, October 10, 1689," Ibid., 635-636.

${ }^{108}$ Biemer, Women and Property, 8-9; Narrett, "Dutch Customs of Inheritance," 29; “Men's Wills and Women's Property Rights in Colonial New York," 101; Voorhees, "'how ther poor wives do, and are delt with"," 42-43.

${ }^{109}$ Lawrence H. Leder, Robert Livingston, 1654-1728, and the Politics of Colonial New York (Chapel Hill, 1961), 57-60. The administrative change referred to was the creation of the Dominion of New England in 1685. 
beginning of that unrest to the Board of Trade in May 1689. ${ }^{110}$ However, Nicholson may have aggravated an already tense situation and compounded factionalism. Owing to dispute over or refusal by "severall Merchants" to pay customs and others duties, Nicholson called a meeting of

"all the civil Magistrates and military officers of his City, and with their consent and advise, did order that the said Revenue arising by the Customs Excise and Weighhouse from the first day of this instant month of May sh ${ }^{\mathrm{d}}$ be applied towards the paying and defraying of the Charges of $\mathrm{s}^{\mathrm{d}}$ Fortifications, by which meanes we hope in some manner to preserve the said Revenue."111

Nicholson did so with the advice and consent of several members of the

Colonial Council united by ties of blood and marriage who later vehemently condemned

Leisler. The Council members were Frederick Philipse, Stephanus van Cortlandt, and Nicholas Bayard. ${ }^{112}$ All women in New York in the 1680s felt the negative effects of anglicization of law in the 1680 s owing to their status as femme covert. However, wives of husbands in the network of Stuart government patrons suffered least. Like other women anglicization of law denied these wives many of their former avenues of expression. Nevertheless, they worked alongside their husbands to build a coterie of

110"Lieutenant Governor Nicholson and Council of New-York to the Board of Trade, May 15, 1689,"NYCD, 3: 574-576. Nicholson was acting as governor owing to the incarceration of Edmund Andros by Boston rebels.

${ }^{111}$ Ibid., 575 .

${ }^{112}$ Ibid., 576. Neither van Cortlandt nor Philipse were as vituperative in their language about Jacob Leisler as was Bayard. See, "Stephen Van Cortlandt to Governor Andros, July 9, 1689", Ibid., 590-597; and, "Messrs. Philips and Van Cortlandt to Secretary Blathwayt, August 5, 1689,” Ibid., 608. 
financially and politically well connected people united by blood and marriage. ${ }^{113}$

Leisler and his following represented a threat to the power and they sought to protect their interests. ${ }^{114}$

Verleth was not the only anti-Leisler woman to act impetuously with physical violence. In 1690, Leisler's commissioner, Jacob Milbourne was physically assaulted by Margareta Slichtenhorst Schuyler. ${ }^{115}$ Schuyler was the widow of Philip Pietersen Schuyler, and the sister-in-law of Stephanus van Cortlandt, brother of Maria van Rensselaer. Maria had a low opinion of Philip and Margareta Schuyler owing to their efforts to acquire land that she was trying to secure through official and unofficial channels. On two occasions Maria referred to Philip Schuyler as an interloper and once inferred deceit by Margareta. ${ }^{116}$

The records of women's involvement in Leisler's Rebellion are sparse and the assertion that women assumed positions of leadership is equivocal. ${ }^{117}$ However,

${ }^{113}$ For example, Margaret Hardenbroeck, wife of Council member Frederick Philipse, continued commercial activity in the 1680s. Biemer, Women and Property, 39.

${ }^{114}$ Voorhees, "'how ther poor wives do, and are delt with'," 45.

${ }^{115}$ Voorhees, "'how ther poor wives do, and are delt with'," 41. Margareta was the daughter of Brant van Schlectenhorst, who was one of the early directors of Rensselaerswijck. Biemer, Women and Property, 59.

${ }^{116}$ CMVR, 125, 169. The Schuylers efforts were part of the larger effort by Robert Livingston to acquire Rensselaerswijck. Livingston was married to Alida Schuyler, daughter of Philip and Margareta. Biemer, Women and Property, 59; CMVR, 128.

${ }^{117}$ Charles Howard McCormick, Leisler's Rebellion (New York, 1989), 220, maintained women were among the internal leadership. 
leadership is difficult to define in a series of events that developed from personal rivalries and religious extremism exacerbated by external political change. ${ }^{118}$ Specifically, polarization of factions was a process and leadership emerged and sometimes submerged as positions crystallized. Nevertheless, women played a decisive role in events through their communication network. On June 26, 1689, Nicolas Bayard recorded, "the widow Peyster, Mrs Van Brugh and severall others told my wife that the rabble of Leiseler had sworne to have mee alive or dead, and therefore advized mee to departe very suddanly." ${ }^{119}$ In June 1689, Bayard's wife was brought before the Council, governed by Leisler. She was searched and found to be carrying in her purse letters for the opposition. ${ }^{120}$

Division into factions and expressions of personal dislike toward Leisler illustrates the complexity of understanding the causes of Leisler's Rebellion and explains historians' varied interpretations. ${ }^{121}$ Specifically, evidence of factionalism based on lineage and marriage encourages the interpretation that the Rebellion was a popular uprising against entrenched interests. ${ }^{122}$ The epithet used most commonly by

${ }^{118}$ Christoph, "Social and Religious Tensions in Leisler's New York," De Halve Maen, vol. 67, no. 4 (Winter, 1994), 87-92.

${ }^{119}$ NYCD, 3: 604.

${ }^{120} D H N Y, 2: 262$.

${ }^{121}$ Voorhees, “The Execution: Jacob Leisler, traitor or martyr?" Hudson Valley Magazine (February, 1990), 25-28: 25.

${ }^{122}$ Ibid.; Christoph, "The Colonial Family: Kinship and Power," in Zeller, ed. A Beautiful and Fruitful Place, 111-118. 
Nicholas Bayard to describe the Leislerians was "rabble," though on occasion he also referred to them as "Rogues, Rascalls, Villans \& Divells." ${ }^{23}$

Class division between the entrenched interests of the anti-Leislerians and Leisler and his administration was encouraged by Bayard and others. Although Leisler's pedigree was in many ways superior to his own, Bayard portrayed him as bourgeois. ${ }^{124}$ Bayard's class prejudice was revealed in the pamphlet, "A Modest and Impartial Narrative," which most historians of early New York believe he wrote. Of Leisler, he wrote,

"This is too little to satisfy the unsatiable Ambition of this Great usurper, Leysler, who could not content himself with the station nature had fitted him for, and placed him in, but his soaring, aspiring mind aiming at that which neither his birth nor education had ever qualified him for, to wit, to be their Majesties Lieutenant Governor of this Province. .." ${ }^{25}$

Class prejudice is not an indictment of Bayard, nor of the faction to which he belonged. Instead, it is a reflection of the structure of New York Dutch society that

123“"Colonel Bayard's Narrative of Occurences in New - York, from April to December, 1689," NYCD, 3: 642.

${ }^{124}$ Fabend, “'According to Holland Custome'," 3; Bayard's hatred of Leisler was due to more than class prejudice. During his tenure as Lieutenant-Governor, Leisler had Bayard jailed. In January 1689 in a fawning, subservient way Bayard was compelled to petition Leisler for relief. He wrote, in part, "That the petitioner \& Prisoner since this two days, has been taken with an extreme sickness in Body, \& humbly craves your Honorable Commisiration, the Petitioner acknowledging his great Error in disgrading the authority which he humbly ownes \& Craves pardon for. . . Promising to behave himself from henceforth with all submission. ..." $D H N Y, 2: 63$. I believe this petition goes a long way toward explaining the savage treatment of Leisler and Milbourne after their surrender of New York to Colonel Slaughter in 1691.

${ }^{125}$ Andrews, ed. Narratives, 326-327. 
developed in response to changing political authority and increasing anglicization. Specifically, the group of Dutch New York elite that developed a symbiotic relationship with the Stuart government used traditional Dutch cultural pathways to achieve power. One cultural characteristic that stands out was their dependence on marriage to cement and create unions between families. This did not directly confer power on women. Nevertheless, it made them integral to the structure of power. In combination with a cultural tradition that placed unusual responsibilities and opportunities on women in their roles as wives, marriageability took on greater significance as an expression of female authority. Therefore, an advantageous match between, for example, Maria van Cortlandt and Jeremias van Rensselaer, was beneficial to both families. Moreover, through the familial connections made by the marriage, Maria exercised considerable power after the death of Jeremias. Some marriages were not so advantageous.

The marriage of Elsie Tymens and Jacob Leisler began a series of events that contributed significantly to the passions expressed in Leisler's Rebellion. Their marriage started the internecine struggle for the estate of Govert Loockermans that pitted Jacob Leisler and, by extension, Elsie, against her immediate and extended family. The struggle and events of Leisler's Rebellion engendered much of the passionate factionalism that characterized New York politics for many decades afterward. In addition, after Jacob Leisler's violent execution, Elsie Leisler was initially left destitute. ${ }^{126}$

\footnotetext{
${ }^{126}$ The mutilation of Leisler's body alluded to earlier included at the least decapitation. "The Commander-in-Chief and Council of New - York to Mr. Blathwayt, Aug. 6, 1691," NYCD, 3: 794-796: 794.
} 
Following Leisler's execution in April 1691, his estate was seized by the government. On August 8, 1691, Elsie Leisler wrote to her son Jacob Leisler, Jr., in England,

"After they have Robd us of al they have tacken the great wood boat too, and they Ceep and detain the books from me, So that I am now Stript of all and have nothing left for me and your sisters to live on am now forced to borrow mony to buy bred with." 127

In the same letter, she mentioned a threat of eviction from her home ordered by the Governor, Colonel Henry Sloughter and, the following year, acting Governor Richard Ingoldsby followed through. ${ }^{128}$ Evidently the passions inspired by Jacob Leisler were still intense, for they evicted her in the middle of winter in January 1692.

However, like many Dutch women in New York, Elsie Leisler was accustomed to independent initiative. ${ }^{129}$ Despite the loss of her husband and property, she petitioned the provincial government for relief and organized efforts for official intervention by the crown. She petitioned Ingoldsby for return of confiscated property owing to, "being Destitued of any Maenes for $\mathrm{y}^{\mathrm{e}}$ Support of her Selfe \& distressed family: for the

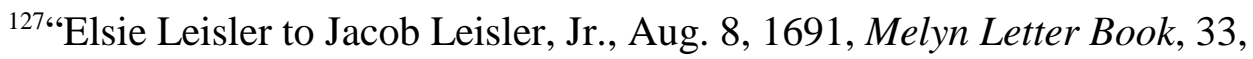
courtesy of David Voorhees.

${ }^{128}$ Ibid.; Voorhees, “'how ther poor wives do, and are delt with'," 47. Ingoldsby was acting governor until the arrival of Benjamin Fletcher, who was governor from 1992 to 1998.

${ }^{129}$ Elsie Tymens Leisler was a trusted and competent partner of Jacob Leisler. 
approaching Winter." ${ }^{130}$ In addition, she instructed her son, Jacob, Jr., to petition the crown on her behalf for relief. ${ }^{131}$ In March 1691, Queen Mary interceded for Elsie Leisler and Mary, her daughter and widow of Jacob Milbourne, by issuing an order for restoration of their estates. ${ }^{132}$ However, reversal of the attainder on Jacob Leisler, which required an act of Parliament, did not occur until 1695, and in the interim Elsie continued to suffer at the hands of anti-Leislerians. ${ }^{133}$ Perhaps in an effort to seek some relief, Elsie settled the Loockermans estate with the heirs of Jacob Loockermans in October 1692. However, the agreement was, "according to Holland custom," and Elsie was deprived of an accurate accounting of her patrimony from the Tymens estate. Indicative of the animosity her extended family held for Elsie, the agreement included a clause, "any of the undersigned heirs, who refuses to fulfill this agreement, or any part thereof, will forfeit to the other heirs the sum of one hundred pounds, New York

${ }^{130} D H N Y$, 2: 394-95. Evidence of Elsie's qualification for assuming responsibility for public affairs is contained in an early bill of sale. In December 1675 she received power of attorney from her husband to sell the ketch, Neptune, to William Dyre. "Bill of Sale for Neptune from Elsie Leisler (acting on behalf of her husband) to Capt. William Dyre," December 12, 1675, Leisler Papers, courtesy of David Voorhees.

131" "Petition of the Widow Leisler, Her Son and Six Daughters," New York Historical Society, Collections (1868), I: 335-336, hereafter N.Y.H.S. Collections.

132“"Order of Council in Case of Leisler and Milbourne," March 11, 1691, NYCD, 3: 827 .

133" Petition to the King to Reverse the Attainders," n.d. N.Y.H.S. Collections (1868), I: 336-337. The author of the petition, Abraham Gouvereur, complained Queen Mary II had granted respite from the seizure of the property and imprisonment of the leading Leislerians, but "a good part thereof be still detained from them contrary to the $\mathrm{s}^{\mathrm{d}}$ grant." 
money." "134 It is likely that in October 1692, Elsie Leisler did not possess that much wealth in specie or property.

Nevertheless, Elsie Leisler continued her efforts to overturn the attainders and secure the return of her property and that of other orphaned and widowed Leislerians. For example in August 1694, she solicited monies from Daniel Polemus and Roelof van Kercken, "to help bear the expenses incurred by my son in england for the cause of those who have been in prison because there are some who do not have the ability themselves and I cannot bear the heavy burden alone." ${ }^{135}$ In addition, she continued her petitions to the provincial government which, since anti-Leislerians were in control, refused to relinquish their hold on her property. For example, in January 1694, the Council refused her petition, since "There appearing no letters Patents to his Excellency as alleaged th [Governor] did expresse all readynesse to give obedience to their Maties Council [\&] desired to see them."136 In March 1694, her petition was again considered and again refused. ${ }^{137}$ It was not until May 2, 1695 that at the order of William III, Parliament reversed the treason sentence on Leisler, Milborne, and others and cleared the way for return of the property of Elsie Leisler. ${ }^{138}$

134، Agreement of Loockermans Heirs,” Oct. 21, 1692, Leisler Papers.

135“Elsie Lesiler to Daniel Polemus and Roelof van Kercken,” Aug. 10, 1694, Leisler Papers.

${ }^{136}$ Minutes of the Council of New York, January 4. 1694.

${ }^{137}$ Ibid., March 26, 1694.

${ }^{138} \mathrm{DHNY}, 2: 435-436$. 
How can Elsie Leisler's determination and ability to overcome the retribution of the enemies of her husband be explained? One may argue that desperate times called for desperate measures. The temptation to compare her with the handful of early American English women who displayed uncommon leadership in adverse circumstances is compelling. Specifically, the efforts of Margaret Brent in Maryland in the seventeenth century, Eliza Lucas Pinckney in South Carolina in the eighteenthcentury, and Hannah Lee Corbin in Virginia in the Revolutionary period come to mind. ${ }^{139}$

Circumstances were extraordinary for Elsie Leisler. After her husband's execution she became a focus of pent-up anti-Leisler sentiment. Considering the Loockermans estate feud and the settlement of the Loockermans estate to Elsie's disadvantage, denying inherited property to her is unsurprising. However, her response is also unsurprising. Owing to her Dutch heritage she was equipped with skills necessary to organize efforts for restoration of her property and that of other Leislerians. Education and administrative management of family financial ventures were not exclusive to women in Dutch culture in early America, but were more common among people with different status. Like Maria van Rensselaer, Catelyntje Rapalje, the wife of Jan Harmensen, and even Judith Verleth, Elsie Leisler used her skills to defend and promote the interests of her family and community of friends established through her

139،"Descendants of Coll ${ }^{\circ}$ Giles Brent," De Bow's Review, vol. 5 (1851), 43; Berkin, "The Rise of Gentility: Class and Regional Differences in the EighteenthCentury," First Generations: Women in Colonial America (New York, 1996), chap. 6: 129-164, 129-154; Gherke, "Beyond a Woman's Sphere: Public Lives of Elite Women in Eighteenth-Century Virginia," Duquesne History Forum (October 1996). 
marriage to Jacob Leisler.

The ways Dutch women exercised power in New Netherland and seventeenthcentury New York does not fit traditional gender-based social constructs used by most historians of early American women. More specifically, exercise of power by early American Dutch women does not follow patterns used to explain early American English women. In their identification with family and community, they were similar to women with English heritage. However, with those conventional avenues of women's expression of power, Dutch women sought opportunities and accepted responsibilities often unlike those of other women in early America. 


\section{Chapter Five}

\section{The Experience of Dutch Widows in New Netherland and Seventeenth-Century New York}

“. . . the worthy Annete Dircx, widow of the deceased Pieter Kock, of this city, burgher

... on the one part, and Willem Abrahamsen van der Brode with Deonys Isaaksen van Hartoghvelt, carpenters, who declared to have contracted with each other for the building and building wages of a house ... "

On October 12, 1674, Maria van Rensselaer became the widow of her partner in life, Jeremias van Rensselaer. ${ }^{2}$ Since 1658 , Jeremias van Rensselaer had been director of Rensselaerswijck, a large land grant known as a patroonship reminiscent of a feudal manor near, what is today, Albany, New York. ${ }^{3}$ It was granted to Jeremias' father,

${ }^{1}$ Kenneth Scott and Kenneth Stryker-Rodda, eds. New York Historical Manuscripts, Dutch: The Register of Salomon Lacharie, Notary Public of New Netherland, 1661-1662 (Baltimore, 1978), 14, [hereafter cited as Register of Salomon Lacharie.

${ }^{2} C M V R, 3$.

${ }^{3}$ The, "Freedom and Exemptions," granted by the Dutch West India Company, upon which the patroon system was based, used feudal phraseology. Thomas J. 
Kiliaen, in $1630 .{ }^{4}$ In addition to managing the affairs of Rensselaerswijck, Jeremias acted as an agent in America for the commercial interests of his family and other individuals and families in the United Provinces. Consequently, his death in 1674 was potentially harmful to the capital and commercial interests of many entrepreneurs in Europe and America.

Nevertheless, by the time of Jeremias' death, the van Rensselaer family in Europe was a remnant of what it had been only a few years before. The immediate family in Europe was dwindling. The patriarch of the family and original patroon of Rensselaerswijck, Kiliaen, died in 1643 and his widow, Jeremias' mother, Anna, who managed the family's commercial affairs following her husband's death, died in 1670. In addition, several of Jeremias' siblings, including two sisters and a half brother, preceded him in death. ${ }^{5}$ More importantly, owing to affairs in the Netherlands, the two eldest surviving sons, Jan Baptist and Richard, were unable to directly manage Rensselaerswijck. After Jeremias' death, Nicolaes, a clergyman and the younger brother of Jeremias, went to New York at the request of Jan Baptist van Rensselaer to attend to the patroonship and assume responsibilities with the domine of the Reformed Church in

Condon, New York Beginnings: The Commercial Origins of New Netherland (New York, 1968), 125.

${ }^{4} N Y C D, 1: 44$. During his life Kiliaen van Rensselaer managed Rensselaerswijck from the Netherlands with appointed on-site managers to assist him. He never personally traveled to the patroonship.

${ }^{5}$ CJVR, 5-6. 
Albany. ${ }^{6}$

As important as the death of Jeremias van Rensselaer was to the van Rensselaer family in Europe and to the local and transoceanic commercial activities of Rensselaerswijck, no one experienced a greater loss than Maria van Rensselaer. She married Jeremias when she was sixteen, but owing to her background and training was prepared for life as the wife of one of New Netherland's affluent bachelors. However, despite her early training and the talents she displayed in the management of Rensselaerswijck during widowhood, at times she found the responsibilities of widowhood overwhelming. Her primary concern was protecting the patroonship for her progeny. Specifically, she was interested in passing on the responsibilities of Rensselaerswijck to her son, Kiliaen. Notwithstanding her wish, within two years of Jeremias' death, Nicolaes was appointed director of Rensselaerswijck by the van Rensselaer patriarch by succession, Jan Baptist. ${ }^{7}$ The appointment was approved by Governor Edmund Andros. In a letter to Jan Baptist in 1675, Maria expressed disappointment in his decision to name Nicolaes director. In addition to expressing her desire that Kiliaen be named director of the patroonship, Maria maintained that prior to

${ }^{6}$ Nicolaes was the seventh child of Kiliaen van Rensselaer. Ibid., 5. He was sent to assist Domine Gideon Schaets.

${ }^{7}$ Nicolaes petitioned Andros for provisional appointment as director of Rensselaerswijck in October 1675. In April 1676, he presented credentials to the Court of Albany signed by Jan Baptist and Governor Andros that confirmed his appointment. However, Maria was named treasurer and her brother Stephanus van Cortlandt was named bookkeeper of the patroonship by the Holland directors. CMVR, 4 . 
his death, Jeremias had expressed his desire that Kiliaen be named director. ${ }^{8}$ Inasmuch as Kiliaen was only twelve years old at the time, it was recognized his mother intended to act as director until he reached age of majority.

If de facto management of Rensselaerswijck was her goal, Maria didn't have long to wait. Nicolaes, who was ordained in the Church of England, and whose appointment as Domine of the Reformed Church of Albany came from the Duke of York, was opposed by the local congregation. The congregation opposed his appointment enough to accuse him of, "preaching false doctrine." As a result, according to A.J.F. van Laer, he was deposed as Domine by Governor Andros. ${ }^{10}$ According to Richard van Rensselaer, the third surviving van Rensselaer brother, the false doctrine mentioned in the accusation included showing, "Quaker tendencies." After Nicolaes' deposition and his subsequent death in 1678, which was soon followed by the death of Jan Baptist, Maria took over responsibilities for Rensselaerswijck.

However, her activities in behalf of the patroonship were not as official director.

Rather, she performed her duties through the nominal appointment of her brother,

8“Maria van Rensselaer to Jan van Wely and Jan Baptist van Rensselaer, November 1675?," Ibid., 13-16.

${ }^{9} \mathrm{He}$ was also not the best choice to become director of Rensselaerswijck. According to Richard van Rensselaer, "he did not care to work." And, he had difficulty determining an occupation. "Richard van Rensselaer to Jeremias van Rensselaer, Nov. 30, 1658," CJVR, 116-117.

${ }^{10}$ Van Laer, "Preface," CMVR., 7. Van Laer may have meant he was deposed as director of Rensselaerswijck.

${ }^{11}$ CJVR, 117. 
Stephanus van Cortlandt, to the directorship.

Appointment of Stephanus van Cortlandt as director was a judicious and practical effort to keep Rennselaerwijck intact and in Maria's control during a period of gradually increasing anglicization of law that reflected English patriarchal culture. ${ }^{12}$ Women in England and England's colonies in America had more independence in widowhood than they experienced at any other time in their lives. Nevertheless, as widows their ability to continue enterprises they helped attend during marriage was often dependent on their late husbands' management abilities and whether these husbands had shared non-domestic managerial and fiscal responsibilities with their wives. A single woman's appearance in court was a rarity in the English colonies in America. Owing to their legal status as femme covert during marriage, the first time many colonial English women in America appeared in court was when they were required to probate their deceased husbands' wills. ${ }^{13}$ While there were many widows who successfully managed their late husbands' affairs for their own benefit in colonial English America, there were also widows who knew little about their husbands' estates. $^{14}$

\footnotetext{
${ }^{12}$ The remaining van Rensselaer brother, Richard, was unable to come to New York to attend affairs and management of Rensselaerswijck. Appointing Maria de facto director allowed uninterrupted management of the patroonship's fiscal affairs.

${ }^{13}$ Norton, Founding Mothers and Fathers, 157.

${ }^{14}$ Martha J. King, "'What Providence Has Brought Them to Be': Widows, Work, and Print Culture in Colonial Charleston," 147-166; Judith A. Ridner, "To Have Sufficient Maintenance': Women and the Economics of Freedom in Frontier Pennsylvania, 1750-1800," 167-190; Vivian Bruce Conger, “'If Widow, Both Housewife and Husband May Be': Widows' Testamentary Freedom in Colonial
} 
Particularly in the seventeenth century when development of a unique American culture was embryonic, circumstances of the colonial environment mandated more latitude for wives. The circumstances required them to assume responsibilities and take advantage of opportunities than they could under common law in England. ${ }^{15}$ The unique conditions of early American life help to explain why English common law was slow in achieving hegemony in America and was never uniformly applied in any colony. ${ }^{16}$ However, the exigencies of colonial American life did not lessen many effects of English cultural patriarchalism. English patriarchy included the view public activities, such as representation of family affairs in court, were the responsibility and prerogative of males. ${ }^{17}$ Widows were often dependent on grown sons, sons-in-law, male executors appointed by their husbands, or other males to assist with probate. Further, while it was applied differently in individual English colonies, under common law

Massachusetts and Maryland," 244-266, in Eldridge, ed. Women and Freedom in Early America; Joan M. Jensen, Loosening the Bonds: Mid-Atlantic Farm Women, 25-26; Norton, "Eighteenth-Century American Women in Peace and War: The Case of the Loyalists," $W M Q, 3^{\text {rd }}$ ser. no. 33 (1976), 386-409. Norton surveyed the claims of 468 women refugees in England after the American Revolution and found only forty-three were able to provide adequate information about their late husbands' estates.

${ }^{15}$ Morris, "Women's Rights in Early American Law," Studies in the History of American Law, chapter 3: 126-200, 126.

${ }^{16}$ Salmon, "Diversity in American Law," Women and the Law of Property in Early America, chapter 1: 3-13. Another reason for lack of wholesale use of English law in seventeenth-century America was ignorance of English law by colonists. That is, few seventeenth-century Americans had formal legal training. See, Peter Hoffer, "Preface," Law and People in Colonial America, ix-xiv; and, Friedman, History of American Law.

${ }^{17}$ Brown, Good Wives, Nasty Wenches, and Anxious Patriarchs, 3; Salmon, Women and the Law of Property, 19. 
dower interests did not succeed past the life of widows. ${ }^{18}$

In contrast to court records in most English colonies, married Dutch women so frequently acted independently in debt litigation and other civil suits in New Netherland that their appearance in court records was commonplace. Many New Netherland women received experiential training in public commercial roles before marriage that served them and their families well both in marriage and widowhood. For example, as indicated earlier, prior to her marriage to Jeremias van Rensselaer, Maria van Cortlandt worked in her father's brewery where she acquired experience in commercial accounting and sales.

Any training in commerce and other public roles women received in their parent's household was usually diligently applied in their own households after they married. There are enough records of married women who represented their family's interests in court to show wives actively pursued their family's financial and proprietary interests. Married women's responsibilities for the assets of their families in New Netherland was a cultural expression based on historical, religious, and economic foundations. ${ }^{19}$ In addition to married women's appearances in court, expressions of grief by widowed husbands are testimony to the importance of wives to their families. In writing his old friend, Jeremias van Rensselaer, a congratulatory letter on the latter's marriage to Maria van Cortlandt, Pieter Hartgerts of Amsterdam was compelled to offer

\footnotetext{
${ }^{18}$ Morris, Studies in the History of American Law, 161.

${ }^{19}$ See "More Than Deputy-Husbands," chapter 1 and "Women, the Colonial Economy and Anglicization of Law," chapter two.
} 
news of his own wife's death. With heartfelt grief, he related,

"My wife, God help me, died recently in childbed, after she had been delivered of a lifeless child, so that I am left sitting here between two chairs in the ashes." 20

Hargarts' metaphoric expression of grief comes through eloquently with reference to sitting in ashes, but something more is implied by the two chairs. Literary visualization of two empty chairs connotes recognition of a tragic end to a marital partnership. Inconsolable grief and inability to function without his wife was implied by Hargarts use of metaphor.

Less esoteric was Domine Jonas Michaëlius' expression of grief after the death of his wife in 1628. She died soon after their arrival in New Netherland. After her death he wrote to Domine Adranus Smoutius in the Netherlands,

"I cannot let pass, without embracing it, according to my promise. And, at first to unburden myself in this communication of a sorrowful circumstance, it pleased the Lord, seven weeks after we arrived in this country, to take from me my good partner, who had been to, for more than sixteen years, a virtuous, faithful, and altogether amiable yokefellow; and I now find myself alone with three children, very much discommoded without her society and assistance." 21

Several widowed Dutch women were less emotional, but made platitudinous reference to the biblically-based historical plight of widows. Maria Momma, widow of

${ }^{20}$ CJVR, 320 .

21،"Letter of Reverend Jonas Michaëlius, 1628," (to Reverend, Mr. Adranus Smoutius in Amsterdam), J. Franklin Jameson, ed. Narratives of New Netherland, 1609-1664 (New York, 1937), 122. 
Wouter van Twiller, one of the early directors of New Netherland, an investor in Rensselaerswijck, and nephew of Kiliaen van Rensselaer, the first patroon of Rensselaerswijck, reflected,

"It was so sad for me that I become [burdened with] so much trouble and loss, where quietude would serve me better. But you must take it all in good part and say with Job: 'What, shall we receive good at the had of God, and shall we not receive evil'? The Lord's will must be done. He has promised to be a husband unto the widow and He will relieve me of all my sorrow." 22

Despite her profession of faith, Maria Momma was not spiritually patient enough to leave matters completely to God. She sought to advance her own circumstances in widowhood. The excerpt above was from a letter to her cousin by marriage, Jeremias van Rensselaer, whom she depended upon to collect debts owed to her late husband. Reluctant to offend his neighbors through formal prosecution and debtors' practical inability to pay their debts with hard currency in a cash poor economy, van Rensselaer found collecting debts difficult. At times he was better able to collect from those who owed him personally rather than those who were indebted to the people he represented. ${ }^{23}$ Van Rensselaer's reluctance to force payment through lengthy and costly litigation, in addition to incurring, "the hatred of the people if I deal too harshly with them [because?] they were good people," caused complaint from Mrs. Momma. ${ }^{24}$

22“"Maria Momma to Jeremias van Rensselaer, Dec. 16, 1659,” CJVR, 123.

23“"Jeremias van Rensselaer to Jan Baptist van Rensselaer, June 6, 1660,” Ibid., 221.

\footnotetext{
${ }^{24}$ Ibid.
} 
Commenting on van Rensselaer's inability to collect debts owed to her through her late husband's estate, Maria Momma related,

"You will please do the best you can in the matter. I am surprised that people are so slow in paying what they owe. They ought to remember that [some day] they also may leave a [widow] and children and that those will likewise be glad to have what [is due them]." 25

The hardships experienced by Maria van Rensselaer after the death of her husband and her valiant and successful effort to surmount them make her a heroic personage in early American history. However, reference to her widowed status in letters was intended to have a specific effect on their recipient, Richard van Rensselaer, her brother-in-law. Richard van Rensselaer, who succeeded to patriarch of the family after the death of Jan Baptist in 1678, repeatedly sought accurate accountings of the liabilities and assets of Rensselaerswijck with particular interest in any profits that might be forthcoming. Richard van Rensselaers's interest in profits from Rensselaerswijck was not personal except insofar as he was responsible for an accounting to the heirs of the original investors and creditors. ${ }^{26}$

The initial information provided Richard by Maria was unsatisfactory for his purposes. ${ }^{27}$ However, on several occasions she made clear to Richard the state of her

25“"Maria Momma to Jeremias van Rensselaer, Dec. 16, 1659,”Ibid., 193.

26“"Richard van Rensselaer to Maria van Rensselaer, May 4/14, 1682," CMVR, 61. Kiliaen van Rensselaer had majority interest in Rensselaerswijck with 6/10 interest. "Richard van Rensselaer to Peter De Lanoy, September 1/11, 1684," Ibid., 159.

27“"Richard van Rensselaer to Maria van Rensselaer, May 4/14, 1682," Ibid., 64. Nor was he able to provide her with information about goods in the Netherlands 
condition prevented administering Rensselaerswijck in the manner he desired. As early as 1680 , she complained that the death of her husband left her with increasing debts and six children. ${ }^{28}$ She was able to overcome immediate consequences of the poor fiscal condition of Rensselaerswijck, but she was unable to resolve the primary causes of the patroonship's perpetual debt. A letter to Richard van Rensselaer in August 1683 implied she was becoming impoverished. ${ }^{29}$ She appealed to him for help with reference to her widowed condition, pleading, "I pray brother to take that into consideration sometime and to [help] a sorrowful widow." ${ }^{30}$

The pleas of Maria Momma and Maria van Rensselaer indicate the universal association of widowhood with poverty arising from women's perceived congenital weaknesses relating particularly to public affairs. Commerce and law changed some of the fundamental structures of patriarchalism in Dutch culture and gave women responsibilities and opportunities rare in other cultures. Nevertheless, language continued to associate widowhood with a stage of a woman's life characterized by

belonging to her deceased husband, claiming a "multiplicity of affairs," prevented action on her request. "Richard van Rensselaer to Maria van Rensselaer, July 12, 1680," Ibid., 34. 38.

28“"Maria van Rensselaer to Richard van Rensselaer, September(?), 1680,” Ibid.,

${ }^{29}$ She maintained, "I can not live with my family on 200 schepels of wheat and then receive calls from the most prominent people every day." "Maria van Rensselaer to Richard van Rensselaer, August 15, 1683," Ibid., 117.

${ }^{30}$ Ibid. 
destitution. ${ }^{31}$ The image of the impoverished widow was available to widowed women who sought relief from aggressive creditors and others who demanded reconciliation of accounts.

This is not intended to deny that widows financial conditions were worsened following the deaths of their husbands. Rather, it indicates status is another important category for understanding the conditions of widows in New Netherland and seventeenth-century New York. Widows like Maria van Rensselaer, Maria van Twiller, Margaret Hardenbroeck, and others were secure in their ability to independently manage affairs after the deaths of their husbands. However, elite status by birth that was maintained through endogamous marriages gave them advantages unavailable to most widows. Elite Dutch women often did not need male benefactors for maintenance and frequently represented their own interests during widowhood. Therefore, remarriage after the death of a husband was an option rather than an economic necessity for them.

There are many compelling reasons why an individual might choose to remarry after the death of a spouse. Companionship, legitimate and Church sanctioned sexual activity, assistance in rearing children, and social pressure in a population with a skewed sex ratio are among them. However, one of the most important considerations in early America, particularly for widowed women, was financial. ${ }^{32}$ Partnership characterized

\footnotetext{
${ }^{31}$ Grotius, Jurisprudence of Holland, 29-31.
}

${ }^{32}$ Herbert Moller, "Sex Composition and Correlated Culture Patterns of Colonial America," WMQ, vol. 2, no.3 (March, 1945), 113-153: 140; Lois Green Carr and Lorena S. Walsh, "The Planter's Wife: The Experience of Widows in Seventeenth-Century Maryland," WMQ, vol.34, no.4 (October, 1977), 543-571: 555; Terri Lynn Snyder, “'Rich Widows Are the Best Commodity This Country Affords': Gender Relations and 
Dutch marriages in New Netherland and seventeenth-century New York. Evidence of partnership includes the Dutch custom of joint wills and equitable division of testamentary and intestate property through practice and law. Consequently, many widows were capable of managing affairs after the deaths of their husbands.

Nevertheless, many widowed women chose remarriage over continued widowhood. ${ }^{33}$

Attending to the needs of orphans and widows was viewed as one of the functions of civil government in New Amsterdam when the city received a charter in 1653. ${ }^{34}$ Assumption of this obligation by the New Amsterdam government was part of an ongoing seventeenth century process in the Netherlands that diverted administrative responsibility for widows and orphans from private managers to public institutions. Private managers included the Reformed Church. Public institutions included the Burgerweehuizen [orphanages for children from propertied families], Aalmeozeniersweeshuizen [orphanages for indigent children], and orphanmaster's functions by municipal courts. The Burgomaster's Court of New Amsterdam assumed the duties of an orphanmaster's court after establishment of municipal government in 1653, but in February 1656, a formal Court of Orphanmasters for New Amsterdam was

Patriarchy in Virginia," (Ph.D. dissertation, University of Iowa, 1992).

${ }^{33}$ Narrett, "Dutch Customs of Inheritance, Women, and the Law in Colonial New York City"; "Patterns of Inheritance in Colonial New York City, 1664-1775: A Study in the History of the Family."

${ }^{34}$ Minutes of the Orphanmaster's Court of New Amsterdam, vi; RNA, 1: 380. Recognition of need for assuming responsibility for administering care for orphans was not immediately translated into creation of a formal body for that purpose. 
created. $^{35}$

In addition to arranging for care of children who lost both parents, the court was required to administer property of children whose fathers or mothers had died intestate. ${ }^{36}$ With the intent of protecting the property of minor children from profligate step-parents, the court was required to administer the property of children whose surviving parent intended to remarry. ${ }^{37}$

Available records do not conclusively prove economic necessity was the primary motivation for remarrying widows. A skewed sex ratio, companionship, and intimacy are powerful reasons for marrying second and even third and fourth times. However, financial security must have been particularly important to widows with children.

number of

\begin{tabular}{|l|c|}
$\mathrm{n}=26$ & children \\
\hline widowed women (15) & 37 \\
\hline widowed men (11) & 22 \\
\hline
\end{tabular}

${ }^{35} R N A, 2: 45$.

${ }^{36}$ When both parents died, the court had several options available. For example, maintenance of the six minor children of Pieter Cecer and his wife, (name not recorded), was turned over to the Reformed Church in January 1656, after the guardians reported the estate of Cecer and his wife had neither property nor money left for that purpose. In June 1657, the two children of Cornelis Croesen and his wife, (name not recorded), deceased, were sent to live with their grandfather in the Netherlands. Minutes of the Orphanmaster's Court, 1: 13, 21-22. It was common practice for will to exclude administration of the estate by the Orphanmaster's Court owing to the Court's conservative investment strategies in administering the property of orphans. See Shattuck, “A Civil Society," 171-172.

${ }^{37}$ In the event guardians had been appointed to administer the estate, surviving spouses sometimes questioned the authority of the court to require an accounting. 


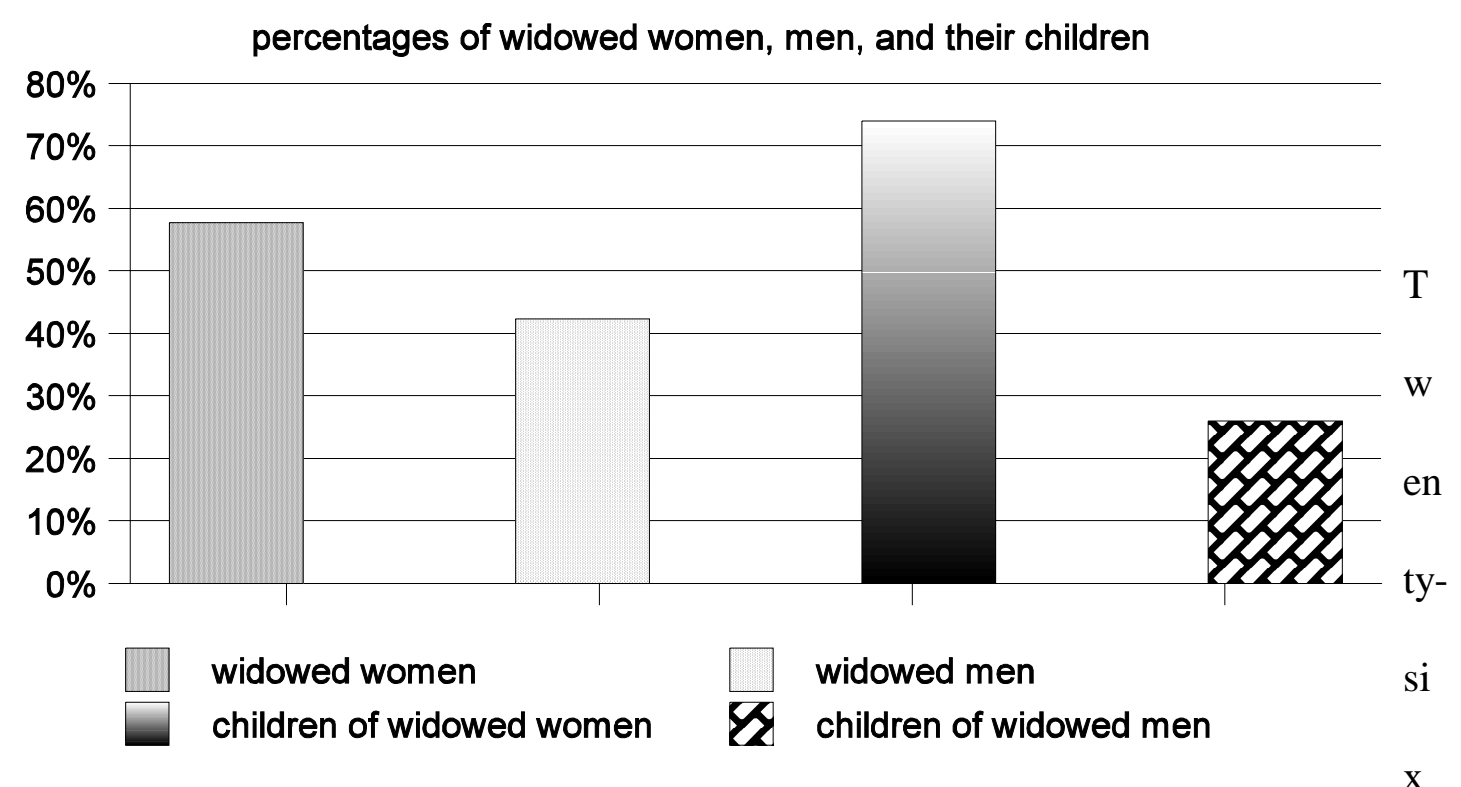

of 49 orphan cases culled from the Records of the Orphanmaster's Court of New

Amsterdam included mandates to surviving spouses with children who intended to

remarry to settle the childrens' legacies. ${ }^{38}$ Fifteen or 57.7 percent of the twenty-six were

${ }^{38} \mathrm{~A}$ variety of cases are contained in the Orphanmaster's Court minutes. The remaining twenty-three cases included settlement of legacies on children of widows who did not intend to remarry, those children who lost both parents, and in one case, 
widowed women while eleven or 42.3 percent were widowed men. However, thirtyseven or 63.7 percent of the children had deceased fathers while twenty-two or 37.2 percent had deceased mothers. The average number of children per household of widowed women was 2.4 , while the average number of children per household of widowed men was 2 . The table and chart on the preceding page represent these figures graphically.

Further analysis of these cases in the Orphanmaster's Court records adds credence to the hypothesis that widowed women with children were likely to remarry for financial reasons. Specifically, widowed women were more likely to have a larger number of dependent children than did widowed men. ${ }^{39}$ The table and graph on the next page indicate the numerical distribution of children per widowed parent by sex.

\begin{tabular}{|c|c|c|}
\hline & $\begin{array}{l}\text { widowed } \\
\text { women }^{40}\end{array}$ & $\begin{array}{l}\text { widowed } \\
\text { men }\end{array}$ \\
\hline 6 & 2 & 0 \\
\hline
\end{tabular}

adult children who sought a court ordered accounting of their legacy owing to their mother's resistance to their private overtures for settlement.

${ }^{39}$ The ages of minor children were not indicated in five of the cases reported.

${ }^{40}$ Two cases did not report the number of children, but indicated the number was plural. 


\begin{tabular}{|l|l|l|}
\hline 5 & 0 & 0 \\
\hline 4 & 3 & 1 \\
\hline 3 & 3 & 2 \\
\hline 2 & 1 & 1 \\
\hline 1 & 7 & 4 \\
\hline
\end{tabular}

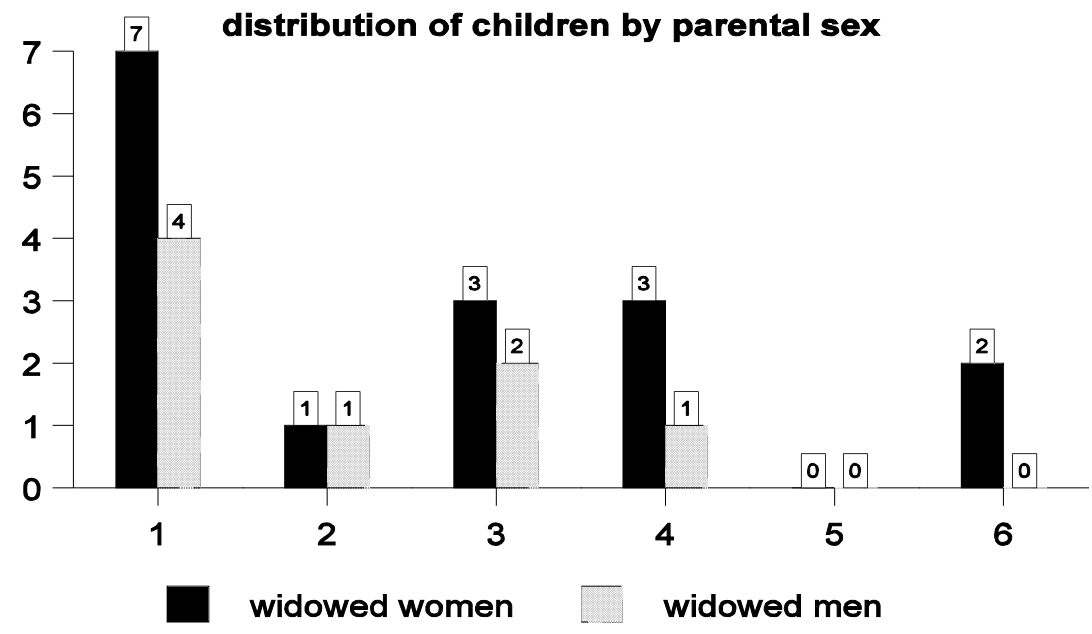

Information gleaned from the twenty-six orphanmaster's cases indicates that material support for their children may have been an important factor for widowed women in their decision to remarry. However, contravening evidence exists in the details of some cases in which husbands died intestate. Specifically, some widowed women challenged the authority of the Orphanmasters Court to require inventories and settlement of their deceased husbands' estates. Each case had unique circumstances that led to the challenge, but all widows who contested the court's authority maintained they were not 
required to give an accounting so long as they intended to remain single. Some widows were adamant in their refusal to follow the court's order. For example, in February 1658, Geertje Hendrick, widow of Andrees Hoppe, maintained she was not required to take an inventory, "so long as she does not marry again." The court demanded the inventory, "according to the customs of our Fatherland." In reply to the court's demand Hendrick asserted, "she does not intend to do it and the Orphanmasters may do what they please." ${ }^{41}$ However, the court did not tolerate challenges to its authority.

At the next court session, Hendrick was asked if she reached an agreement about the children's settlement with previously appointed guardians. She again asserted she need not do so unless she intended to marry again. When the court replied that she must, she asserted, "Must is force," which in proverbial Dutch meant, "What one does by force is done against one's will." By this phrase she acknowledged the futility of further resistance to the court's order and assented to work out an agreement with the guardians. $^{42}$

More curious was the record of Rachel van Tienhoven. Like Geertje Hendrick, Rachel van Tienhoven complained she was not obligated to give an inventory of her husband's estate owing to her intent to remain single. ${ }^{43}$ However, Rachel van Tienhoven had perhaps greater reason to remain unmarried than did Hendrick. Rachel (Vinje) van Tienhoven was married to Cornelius van Tienhoven in

\footnotetext{
${ }^{41}$ Records of the Orphanmaster's Court, 1: 75.

${ }^{42}$ Ibid., 77.

${ }^{43}$ Ibid., 87.
} 
$1630 .{ }^{44}$ Owing to his licentious behavior while married and the suspicious

circumstances of his death, Rachel's condition upon being widowed were unique. ${ }^{45}$

However, during widowhood, she displayed a tenacity for survival common among

widowed women in New Netherland and seventeenth-century New York.

Van Tienhoven was a bookkeeper under Director Wouter van Twiller and was

promoted to Provincial Secretary under Willem Kieft, a position he continued under

Pieter Stuyvesant. ${ }^{46}$ Accused of being a libertine and dissembler by the authors of the

Remonstrance of New Netherland, van Tienhoven was implicated in political intrigue

that affected the administration of Pieter Stuyvesant. Stuyvesant's accusers maintained,

van

Tienhoven's appetites were so strong that:

${ }^{44}$ Rachel [Raghel] Vinje [Vingne, Vinge] was the daughter of Guelyn Vigne, a Huguenot from Valenciennes, France, who immigrated to New Netherland in 1614, or, more likely 1624. Dankaerts Journal, 114-115; T.Welles, Ancestral Tablets from Colonial Days to the Present (New York, n.d.), 192. The marriage of Rachel and Cornelius was reported in, Laila Fulkerson Thompson, A History of the Fulkerson Family from 1630 to the Present (New York, 1979), 8.

${ }^{45}$ I have only sketched the details of Cornelius van Tienhoven's behavior that were relevant to Rachel van Tienhoven. The most significant primary source of van Tienhoven's public and personal activities are contained in NYCD, 1: 433-435, 453-454, 512-518. O'Callaghan, History of New Netherland, or, New York Under the Dutch 2 vols. (New York, 1848), 2: 168-169, 321-322, provided selected information on van Tienhoven, including the unobjective condemnation, "Profligate in principle, a debauchee in morals, addicted to every vice that a corrupt heart could delight in, he ran his career of guilt so triumphantly that he fancied there was no day of retribution for him." [322]

${ }^{46}$ From the, 'Korte Historiael Ende Journaels Aenteycheninge,' by David Pietersz[en] De Vries, 1633-1643 (1655), Jameson, ed. Narratives of New Netherland, 208. 
"With the Indians even, he has run about like an Indian, with little covering and a patch before him through lust for the prostitutes to whom he has ever been excessively addicted, and with whom he has had so much intercourse, that no punishment nor menaces of the Director can drive him from them." 47

If accusations by political enemies were the only evidence of van Tienhoven's licentiousness, historians might well question the veracity of the reports. Unfortunately for Rachel van Tienhoven, and for Cornelius' historical reputation, there is substantially more evidence of an unrestrained sexual appetite that led to blatant disregard for social, legal, and religious standards governing marriage. Specifically, while in the Netherlands to answer charges against his actions and those of Director-General Stuyvesant, Cornelius van Tienhoven began an extramarital affair with Lysbet Janssen Croon van Hoogvelt [Hoogevelt]. Croon was the daughter of the deceased Jan Franssen Croon, a basket-maker in Amsterdam and his widow, Marritgen Ommers. Owing to van Tienhoven's representation of himself as a bachelor, Croon and her mother were ignorant about his marriage to Rachel Vinje. ${ }^{48}$

Van Tienhoven went to great lengths to conceal his marriage to Rachel and his illicit affair with Croon. According to the testimony of Louisa Noë, van Tienhoven requested she find a room for him in Amsterdam. When she desired to know his relationship with Croon, van Tienhoven related, "that he had run away with the woman, NYCD, 1:309.

47"Remonstrance of New Netherland and the Occurences There, July 28, 1649,"

48، SSworn statement of Elizabeth Janns, Innkeeper, before D.V. Schelluyne, Notary Public, December 6, 1651," Ibid., 514. 
against the will of her parents, but that he intended to marry her on the first opportunity." ${ }^{49}$ Additional testimony by other innkeepers where van Tienhoven stayed with Croon indicated van Tienhoven perpetuated the lie he was married to Croon. ${ }^{50}$ Finally, when van Tienhoven was caught by two sheriffs representing The Hague, he was required to pay a fine and "some oysters and a drink for the two sheriffs."

Disregarding his wife and children and the legal, social, and religious tenets of marriage, van Tienhoven was so enamored with Lysbeth he decided to take her back to New Netherland. Upon their arrival in New Netherland, Lysbeth discovered the truth about her paramour's married state and soon thereafter abandoned him. ${ }^{52}$

There are no records of Rachel van Tienhoven's reactions to her husband's extramarital affairs prior to or after he brought Lysbeth van Hoogvelt to New Netherland.$^{53}$ However, the van Tienhoven marriage does not fit the characterization of partnership that defined marriage for many couples in seventeenth-century Dutch

\footnotetext{
49،“Testimony of Louisa Noë to Martin Beeckman, Notary Public, December 8, 1651," Ibid., 515.

50، Testimony of Margareta van Eeda to Martin Beeckman, Notary Public, December 11, 1651,” Ibid., 517.

51“"Testimony of Jacob Thomassen van Kessel, December 8, 1651,” Ibid., 516.

${ }^{52}$ Lysbeth later married Jacob van Curler, on August 4, 1652. "Records of the Reformed Church in New Amsterdam/New York-Marriages," New York Genealogical and Biographical Record.
}

${ }^{53}$ Cornelius van Tienhoven was not the only man or public official to involve himself in extra-marital affairs. See, reference to Arendt van Curlaer [Curler] in chapter 3, "Dysfunctional Marriages." However, owing to the absence of records about the relationship between Cornelius and Rachel van Tienhoven, it cannot be determined how stable the marriage was. 
culture. ${ }^{54}$ Given Cornelius's public responsibilities in New Netherland, Europe, and elsewhere, and his extramarital liaisons, Rachel was fortunate to have been born and lived in a culture that conferred uncommon responsibilities on wives. ${ }^{55}$ Although overcoming legal and financial challenges did not occur without major difficulties, owing to her culturally and circumstantially acquired independence, Rachel was able to confront vicissitudes that harassed her when she acquired widowed status.

The circumstances through which Rachel van Tienhoven became a widow were unique. Specifically, it was uncertain whether Cornelius van Tienhoven absconded or actually died. ${ }^{56}$ Determining Rachel's status was important for a variety of reasons. First, her status prescribed Rachel's legal liability for debts accumulated during her

\footnotetext{
${ }^{54}$ One of the purposes of marriage in the West in the seventeenth-century was to, "Extinguish those Fleshly desires \& appetites incident to humane nature ... " Hugo Paltists, ed. Minutes of the Executive Council of the Province of New York: Administration of Francis Lovelace, 1668-1673. 2 vols. (Albany, 1910), 1: 334.

${ }^{55}$ For example, in his capacity as fiscal (treasurer) of New Netherland, van Tienhoven was sent by Pieter Stuyvesant to Virginia to promote commercial relations between the two colonies. Charles T. Gehring, trans. and ed., "Correspondence (of Pieter Stuyvesant), 1647-1653, New Netherland Document Series, 11 vols. (Syracuse, 2000), 11: 230. Similarly, in 1656, he was sent to Rhode Island. O'Callaghan, ed. "Council Minutes," Calendar of Historical Documents in the Office of the Secretary of State, Albany, N.Y. (Albany, 1865), vol. 8: 169, [hereafter cited as Council Minutes].

${ }^{56}$ Cornelius van Tienhoven's hat and cane were found floating in the Hudson River, giving the impression his boat capsized and he drowned. However, his body was not recovered and more significantly, he was under suspicion of embezzlement of public funds. On two occasions, the New Netherland Council ordered him to turn over the account books for investigation. Ibid., 171, 174. In addition, the council ordered seizure and "seal of all the books and papers belonging to Cornelius van Tienhoven, late fiscal, he having absconded." Ibid., 176. O'Callaghan, History of New Netherland, 322, was unequivocal in his belief van Tienhoven absconded.
} 
marriage to Cornelius. ${ }^{57}$

After the demise of Cornelius van Tienhoven, creditors descended on his estate without regard to its condition or Rachel's claims. Rachel made a variety of attempts to protect her interests and those of her three minor children. On December 21, 1656, the colonial council ordered a watch on the van Tienhoven house because, "his wife is nightly removing baskets of goods from the premises . . . "58 A month earlier, the council ordered confiscation of his books and papers. ${ }^{59}$

During the December 21 session of the council in which a watch was ordered on the van Tienhoven house, an inventory of Cornelius van Tienhoven's personal effects was ordered. ${ }^{60}$ After this order, Rachel began use of legal avenues to protect herself and her children. In the next session, on December 27, 1656, she petitioned for revocation of the order to take an inventory of Cornelius' personal effects. ${ }^{61}$

Official responses to the presumed death of Cornelius van Tienhoven, including Rachel's responsibilities, indicate careful attention to legal requirements without coordination of efforts. Confiscation of van Tienhoven's books and papers allowed the West India Company (WIC) officials to investigate his alleged embezzlement, but denied Rachel protection from creditors and the requirements of law regarding her

\footnotetext{
${ }^{57}$ Grotius, Jurisprudence of Holland, 29.

${ }^{58}$ Council Minutes, 178.

${ }^{59}$ Ibid.

${ }^{60}$ Ibid.

${ }^{61}$ Ibid.
} 
children. In the four year period following Cornelius' "death," 1656 to 1659, she appeared in court fourteen times as defendant or plaintiff. Six of those appearances were as a defendant in original suits against her for nonpayment of outstanding debts. Six others were suits initiated by her for reconciliation of accounts with creditors. ${ }^{62}$

For much of her widowhood Rachel van Tienhoven, who died in 1663, sought return of personal account books and papers seized by WIC officials. As late as December 1661, the Orphanmaster's Court required her to make a report on her husband's property for the purpose of settling her children's paternal estate. She reported it was not possible owing to lack of settlement with the WIC, which retained his books. The court then ordered her to appoint guardians for her children, which was a requirement under Dutch law. ${ }^{63}$ The court suggested the guardians, "may take a hand in the case with the company."

Rachel tried independently to resolve the matter of her husband's books and papers retained by the WIC, but was unsuccessful. She recognized the futility of continuing those efforts and that she could not indefinitely forestall the requirements of the law in regard to her children's paternal legacy. Perhaps owing to exhaustion of

${ }^{62} R N A, 3,4,5$ : passim.

${ }^{63}$ Minutes of the Orphanmaster's Court, 1: 203; Grotius, Jurisprudence of Holland, 39, indicated appointment of guardians was required within eight weeks of the death of one or both parents, "or within the time fixed by local by-laws and customs." In addition, although the court had ultimate authority in appointment of guardians of children whose parent or parents died intestate, the law gave equal consideration to the wishes of surviving widowed women as it did to widowed fathers. Ibid., 37.

${ }^{64}$ Minutes of the Orphanmaster's Court, 1: 203. 
alternatives or recognition of the efficacy of soliciting help from public officials, Rachel turned to the Orphanmaster's Court for assistance in retrieving her husband's books and papers. At her specific request, on March 9, 1662, the court promised, "to do their best for her and decide for that purpose to make ... (a request) to the Director General and Council." ${ }^{\prime 5}$ Unfortunately, the Orphanmaster's Court Minutes registered neither the wording of the request from the court to the Director General and Council nor the reply that came on April 6, 1662. ${ }^{66}$ However, we can conclude she was unable to reconcile the paternal estate prior to her death on February 18, 1663, owing to the appointment of administrators who were charged with making, "an inventory ... to settle and close up the estate for the satisfaction of the creditors and that the heirs may come to their own.. .$^{67}$

Owing to her husband's public roles and the suspicious circumstances surrounding his ostensible death, Rachel van Tienhoven's experiences as widow were unique. In addition, Rachel van Tienhoven had advantages in shouldering the legal responsibilities of widowhood because of her family connections and her role as the wife of an important public official, out of favor though he may have been. Specifically, upon her death the Orphanmasters' Court appointed four guardians,

\footnotetext{
${ }^{65}$ Ibid., 209.
}

${ }^{66}$ According to Berthold Fernow,, trans. and ed., the request was blank in the original and the reply from the Director General and Council was written on the margins of the request and, "as the request is rather long, it cannot be recorded ... and is therefore deposited in the drawer of chest no. 4." Ibid., 214.

${ }^{67}$ Ibid., 232-233. 
including Jan Vinge, her father and Pieter Stoutenburgh, her brother-in-law. The two were former schepens of New Amsterdam. Moreover, through her husband Rachel likely knew the other two guardians, Jacques Cousseau, another former schepen and, Cornelis Steenwyck, a member of the Orphanmaster's Court. ${ }^{68}$

Notwithstanding the unique circumstances of her widowhood, Rachel van Tienhoven's responses to the challenges of widowhood were consistent with those of many other widowed women in New Netherland and seventeenth-century New York. Specifically, she was knowledgeable, tenacious, and resourceful in protecting her interests and those of her children. When her connections with officialdom could not provide legal assistance, as in the case of creditors and debtors, she proved capable of acting independently. In August 1658, she personally defended herself against a suit by Jacob van Cowenhoven, who claimed a payment of 138 florins. The court records show Rachel answered the claim in writing, proving van Cowenhoven had not paid her late husband. In response, the court ordered van Cowenhoven, "to produce further proof on the next Court day." ${ }^{69}$

While Rachel van Tienhoven personally represented her interests in court, she occasionally turned to professional assistance. Two weeks following the suit by van Cowenhoven in August 1658, she was represented by Mattheus de Vos in a suit against Barent Oesterman for 150 florins. $^{70}$ This case is particularly interesting because it

\footnotetext{
${ }^{68}$ Ibid., 233.

${ }^{69} R N A, 2: 421$.

${ }^{70}$ Ibid., 427.
} 
reveals Cornelius van Tienhoven may have mixed public monies with personal accounts. However, it is unclear it van Tienhoven advanced monies to Oesterman for a fine that was levied against him, Oesterman, for an assault charge and Oesterman had not paid it or, if van Tienhoven used Oesterman's fine as collateral for a personal debt. Either way, Rachel was resourceful enough to use experienced legal assistance, i.e., de Vos, in prosecuting the debt. ${ }^{71}$

While Rachel van Tienhoven's actions in response to the difficulties of widowhood were similar to those of many widows in New Netherland and seventeenthcentury New York, they were most consistent with those of other elite women. After the death of her first husband, Pieter Rudolphus De Vries, Margaret Hardenbroeck confounded the efforts of creditors in suits against her late husband's estate. For example, in March 1662, in a suit against the De Vries estate on behalf of Matthys Bode, an Amsterdam merchant, Margaret maintained her brother, Abel, had been sent to Holland with power of attorney to settle the claims. While Abel Hardenbroeck appears in the records of New Netherland on several occasions, he was not necessarily the most dependable person to send on a such a mission. ${ }^{72}$ Consequently, the suit was not settled

\footnotetext{
${ }^{71}$ Mattheus de Vos was one of several notaries in New Netherland. Notaries were trained in Dutch law and licensed to practice after examination by the court. Wessels, History of Roman-Dutch Law, 197-200; Shattuck, “A Civil Society," 55n76.

${ }^{72}$ For example, Abel married Annetje Meinders without having settled the estate of her first husband, Dirck Barensen Smitt, on her children as required by law. When, with the help of Abel, she submitted a statement and inventory of property, the Orphanmaster's Court rejected it and required another which, "after some haggling," was agreed to by Annetje and Abel. Minutes of the Orphanmaster's Court, 1:230-231.
} 
until October $1665 .^{73}$

While it was not common among widows in New Netherland to have difficulties meeting legal requirements and challenges regarding their late husbands' estates, it did occur. This was particularly common among widows whose husbands died intestate. In November 1663, the Orphanmaster's Court made inquires about the estate of Hendrick van der Walle, to his widow Seletje Jans. Jans was asked if she and her husband had devised a will and when she replied in the negative, they inquired about her husband's estate. Jans answered she had no knowledge of her husband's affairs in Holland. However, she volunteered the information that prior to his death her husband requested Joannes de Peister and Joannes Schevelbergh to act as guardians. Assenting to the wishes of the deceased, which was normal procedure, the court appointed de Peister and Schevelbergh as administrators of the estate. ${ }^{74}$

Owing to brevity of information, the circumstances of Leentje Dirckx Servaas is more difficult to discern. However, the single entry of a suit against her by Claas van Elslant for burial expenses associated with her husband's funeral compelled sympathy from the court. When Elslant approached her about the bill she "gave him a foul answer, saying the house was sold and 'Get your pay, where you can."' The indigence of Servaas was implied by the Orphanmaster's Court's reaction to the suit. First, they asked Elslant, "whether he is too hard with the bill." Receiving no answer to the inquiry from Elslant, the court ordered him to take up the matter with Servaas in the Court of

\footnotetext{
${ }^{73}$ Ibid., 203-204.

${ }^{74}$ Ibid., 247.
} 
Breukelen (Brooklyn) for which he was to produce proof of his debt. ${ }^{75}$

Although resort to official authorities for relief was rare, compulsion or sagacity caused some widows who had trouble from creditors to seek relief through requirements of law involving their children. That is, the Orphanmaster's Court sometimes stood between a widow and her creditors. When Thoomas Pouly sued Cathalyna Simsons in the court at Fort Orange for a debt over a horse that was acquired from Pouly by her late husband, Simsons appealed to him by stating she had put matters into the hands of the Orphanmaster's Court. Pouly demanded payment, but the justices ruled the plaintiff had to wait until curators were appointed. ${ }^{76}$ Dutch courts were diligent in protecting widows and their children from impoverishment if circumstances afforded them the opportunity.

Circumstances for dealing with the claims of creditors were materially advantageous for elite widows. However, the presence of material resources also often attracted more creditors who aggressively pursued outstanding debts. For example, in her twenty month period of widowhood between the death of her first husband, Pieter Rudolphus DeVries in 1661 and her marriage to Frederick Philipse in December 1662, Margaret Hardenbroeck was named as a defendant in fourteen civil suits in the Court of Burgomasters and Schepens of New Amsterdam. ${ }^{77}$

Another woman who experienced periods of difficulty in widowhood was

${ }^{75}$ Ibid., 2: 151.

${ }^{76}$ FOCM, 2: 246.

${ }^{77} R N A, 3-4$ : passim. An overwhelming majority of those cases were with Mighiel Muyen, who acted as attorney for Matthys Bode, and Amsterdam merchant. Biemer, Women and Property, 35. 
Johanna de Laet. De Laet was the daughter of Joannes (Johan) de Laet, the first historian of New Netherland. ${ }^{78}$ She was married to Joannes (Johan) de Hulter, who immigrated to New Netherland in $1653 .{ }^{79}$ Following the death of de Hulter in late 1655 or early 1656 , she subsequently married Jeronimus Ebbingh in $1659{ }^{80}$ Johanna inherited one-tenth interest in Rensselaerswijck through her father and de Hulter. ${ }^{81}$ In addition to leaving Johanna a proprietary interest in Rensselaerswijck and other assets, de Hulter also left debts and unfulfilled contracts. Johanna also survived the death of her second husband, Jeronimus Ebbingh, who similarly left her with debts

\footnotetext{
${ }^{78}$ Records of the Orphanmaster's Court, 1: 105n15. Fernow reported Johanna was the widow of Joannes (Johan) de Laet, but this was inaccurate. In a contract with Johann de Laet in 1674, Jeremias van Rensselaer indicated she had inherited her share of Rensselaerswijck from her father, Johan de Laet. CJVR, 458. Jonathan Pearseon, trans. Early Records of the City of and County of Albany and Colony of Rensselaerwyck, 4 vols. (Albany, 1869), 56n3 (hereafter cited as ERA), reported Johanna was the daughter of Johan de Laet and the husband of Joannes de Hulter. The work referred to written by de Laet was, Nieuwe Wereldt, ofte Beschrijvinghe van WestIndien (full title in English: New World, or Description of West-India, collected out of Various Writings and Notes from Various Nations by Joannes de Laet, and provided with needful Maps and Tables). Chapters seven and eleven are reprinted in Jameson, Narratives of New Netherland, 36-60.

${ }^{79} E R A, 1: 56$ n3.

${ }^{80}$ Records of the Orphanmaster's Court, 1: 105. According to Pearson, ed. ERA, 1: 56n3, de Hulter boarded the Graef in Amsterdam in May 1653. By April 4, 1656, Johanna was his widow. FOCM, 1: 262. She married Ebbingh on February 22, 1659. "Records of the Reformed Dutch Church in New Amsterdam/New York-Marriages," $N G B R$.

${ }^{81}$ Jeremias van Rensselaer indicated in 1674 her share was ten percent. “Jeremias van Rensselaer to Jan Baptist van Rensselaer, June 29, 1674," CJVR, 461. She and Jeremias were in disagreement about her efforts to sell her interest in Rensselaerswijck. His desire was, "to be rid of her." Ibid., 241. Johan de Hulter had been a partner in Rensselaerswijck according to Pearson, ERA, 1: 56n3.
} 
and incomplete contracts. Particularly the Fort Orange and Beverwijck court records reveal the concentrated efforts of Johanna to reconcile her inherited indebtedness with inherited assets. In addition, owing to her interests in Rensselaerswijck, the correspondence of Jeremias van Rensselaer further recorded her experiences as a widow.

The period between the death of Joannes de Hulter (late 1655 or early 1656) and her marriage to Jeronimus Ebbingh in 1659 was particularly litigious for Johanna de Laet. Many of her appearances in court were as a plaintiff in suits against those who had outstanding debts against her late husband's estate. For example, in separate actions on July 9, 1658, she brought suit against Jacob Tyssen for 5500 bricks and Cornelis Vosch for 12,000 bricks and 1600 tiles. ${ }^{82}$ Similarly, later in July of the same year, she sued Rutger Jacobsen and Goossen Gerritsen for "about 30 beavers for tiles and brick furnished for the church." ${ }^{, 83}$

De Laet was also a defendant in several suits arising from settlement of de Hulter's estate. Litigation against de Laet began soon after the death of Joannes de Hulter. In February 1656, not long after the death of de Hulter, Johanna was required to call witnesses to confirm fulfillment of a contract made during her marriage. ${ }^{84}$ The case was not resolved until April 1656 when, under oath, witnesses confirmed the delivery

\section{${ }^{82}$ FOCM, 2: 126.}

${ }^{83}$ Ibid., 141. The court assumed the debt and requested a month's delay in making the payment.

\footnotetext{
${ }^{84}$ Ibid., 1: 252.
} 
of, "150 lbs. of butter, five schepels of flour and four traces," by de Hulter. ${ }^{85}$

Subsequent years prior to her marriage to Jeronimus Ebbingh in 1659 saw a number of suits in the Court of Fort Orange and Beverwijck against de Laet for a variety of debts and contracts. ${ }^{86}$

For reasons undisclosed in the records, in November 1657 de Laet sold at public auction possessions she inherited from de Hulter, including a brick kiln, a tile kiln, and her domicile. ${ }^{87}$ While de Laet's specific motives for the sale are in question, selling part of her assets enabled her to resolve her inherited indebtedness. However, this was not the last time Johanna de Laet sought divestment of her property in New Netherland.

Jeremias van Rensselaer had an ongoing debate with Johanna de Laet over her desire to liquidate her interest in Rensselaerswijck. As early as 1660 she approached van Rensselaer about her interest in Rensselaerswijck and indicated her desire to sell it to the van Rensselaer family. ${ }^{88}$ Van Rensselaer repeatedly denied her an account of her interest and indicated the van Rensselaers did not want to buy her out. When, in 1670, he again refused to buy her share, she responded by indicating she would sell it, "to some person or other." ${ }^{89}$ From the beginning, van Rensselaer feared she would sell it,

\footnotetext{
${ }^{85}$ Ibid., 262. A trace is part of a harness used on draft animals used to pull wagons or carriages.

${ }^{86}$ See particularly, Ibid., 2: passim.

${ }^{87} E R A, 1: 56-58$.

${ }^{88}$ CJVR, 241.

${ }^{89}$ Ibid., 425.
} 
"to some yokel or other," and sought the advice of his brothers in the Netherlands. ${ }^{90}$ As a result he managed to delay her efforts for a total of fourteen years. In 1670, when she approached Jeremias about buying her share in the patroonship, he restated his refusal to purchase her interest. ${ }^{91}$ By 1673 , she was even more determined to rid herself of the property.

In September 1673, she petitioned the colonial government, which by that time was headed by Dutch governor, Anthony Colve, for an order to Jeremias van Rensselaer for an "account and relinqua" of her interest in Rensselaerswijck. ${ }^{92}$ After statements and examination of papers related to the petition, the council ordered van Rensselaer, "to deliver, within two months from this date, into the Secretary's office here, to be recorded, an account and relin[q]ua of said administration up to this date." 93 Nine months later Jeremias contracted with de Laet for her share in the patroonship and exchanged her interest for a rented farm, including a farmhouse, a barn, arable land, and livestock. ${ }^{94}$

In an age when marriages came about for reasons other than affinity, it is difficult to determine why Johanna de Laet gave up widowhood to marry Jeronimus Ebbingh in 1659. However, she was careful to manage her own financial affairs after

\footnotetext{
${ }^{90}$ Ibid., 241.

${ }^{91}$ Ibid., 425.

${ }^{92}$ NYCD, 2: 596-597.

${ }^{93}$ Ibid., 597.

${ }^{94}$ CJVR, 458-459.
} 
marriage to Ebbingh. In addition to excluding community property from the marriage, a legal mechanism by which Ebbingh was denied control of her assets and she was not responsible for his debts, de Laet often conducted her own affairs. ${ }^{95}$ In order to settle the Holland accounts of de Hulter for the benefit of her children, in September 1659, de Laet independently traveled to the United Provinces with a considerable amount of her own and Ebbingh's money. ${ }^{96}$ In addition, after her marriage to Ebbingh, she often represented herself in court in efforts to administer property she rented, leased, and sold. $^{97}$

The property of wealthy widows sometimes attracted the attention of individuals willing to take advantage of widows' perceived vulnerability. Robert Livingston was relentless in his efforts to acquire Rensselaerswijck property through his marriage to Alida van Rensselaer, widow of Nicolaes van Rensselaer. ${ }^{98}$ Owing to the requirements of Dutch and English law, when Robert Livingston married Alida van Rensselaer, he assumed Nicolaes' debts. ${ }^{99}$ However, Livingston's claims on Rensselaerswijck, which he maintained derived from his responsibilities for Nicolaes' debts, were not made

${ }^{95}$ Grotius, Jurisprudence of Holland, 31. By excluding community of goods, de Laet also denied herself a share in profits accrued during the marriage.

${ }^{96}$ Minutes of the Orphanmaster's Court, 1: 109, 166-168.

${ }^{97}$ Kingston Papers, 1: 308, 2: 540, 657.

${ }^{98}$ Biemer, Women and Property, 53-55.

${ }^{99}$ Lee, Introduction to Roman-Dutch Law, 79, 81; Richard van Rensselaer to Maria van Rensselaer, May 4, 1682," CMVR, 63. 
exclusively from a sense of duty for repaying those debts. ${ }^{100}$ He married Alida eight months following the death of her husband and, based on his efforts to procure Rensselaerswijck property, sought to profit from his marriage. In a 1680 letter to his sister, Maria van Rensselaer, Stephanus van Cortlandt indicated Livingston was attempting to negate Alida's inherited indebtedness. He cautioned Maria to, "keep a sharp lookout."101 This came after Maria was mildly reprimanded by Richard van Rensselaer for allowing Livingston to see the will of Johan van Wely, the original patroon's brother-in-law. ${ }^{102}$ In 1682, Richard van Rensselaer accused Livingston of seeking, "to avail yourself of unfounded claims and that you are a solicitor of fraudulent affairs."103 Further, Richard considered bringing suit against Livingston through Ludovicus Cobes, who on various occasions acted as secretary for the van Rensselaer interests in New York. ${ }^{104}$

Maria van Rensselaer was fortunate to have people like her brother-in-law, Richard van Rensselaer, and her brother, Stephanus van Cortlandt, to come to her aid in

\footnotetext{
${ }^{100}$ Leder, Robert Livingston, 24-32.

101،Stephanus van Cortlandt to Maria van Rensselaer, December, 1689," Ibid., 43.

102“'Richard van Rensselaer to Maria van Rensselaer, July 12, 1680,” Ibid., 35.

103،Richard van Rensselaer to Robert Livingston, May 4/14, 1682,” Ibid., 65.

104“"Richard van Rensselaer to Maria van Rensselaer, May 4/14, 1682," Ibid., 64. Maria advised against using Cobes because, "he drinks too much and is easily talked over. "Maria van Rensselaer to Richard van Rensselaer, [January?] 1683," Ibid., 86. In the end, at Maria's suggestion, Peter Delanoy was retained to represent the van Rensselaer interests against Livingston. Leder, Robert Livingston, 28-29.
} 
resisting Robert Livingston's machinations. Maria van Rensselaer undoubtedly would have been an able opponent for Livingston without them. However, the family relationships provided by her status, to which Livingston tried to aspire when he married Alida van Rensselaer, accorded her powerful allies. ${ }^{105}$

Wealth and status presented some widowed women with liabilities and opportunities rarely experienced by many non-elite widowed women. However, status was not a prerequisite for widowed women's efforts to legally protect their interests and those of their progeny. A common theme that runs through the records of widowed women's experiences in New Netherland and seventeenth-century New York was willingness to guard material and liquid assets. However, the success of their efforts was often dependent on experiential knowledge acquired during marriage. The circumstances of Metje Wessels and Annetje Dircx [Dircks] illustrate. ${ }^{106}$

Metje Wessels, widow of Wessel Wesselsz[en] was an active new Amsterdam entrepreneur whose status and wealth did not compare favorably to that of elite women. Nevertheless, with resolution she personally defended her interests on many occasions during marriage and after the death of her husband. Her experiences in court before the death of Wesselszen in 1661 enabled her to act with confidence after. ${ }^{107}$ For example,

${ }^{105}$ Ibid., 21. Livingston owed much of his success to the relationships he established when he married Alida. Through his marriage, he acquired what he did not through birth, status. The marriage gave him ties to the Schuyler family, specifically Alida's father, Philip Pieterse Schuyler, his five sons and daughter, Gertruyd, who married Stephanus van Cortlandt.

${ }^{106}$ Dircx was also referred to in some records as Annetje or Anna van Vorst.

${ }^{107}$ Register of Salomon Lacharie, 7. 
in March 1658, she sued Abraham Pietersen for an outstanding debt of 17 florins.

Pietersen had purchased a hog from Wessels for which he was making weekly installment payments. When it was reported Pietersen intended to return home to the Netherlands, apparently without paying the balance of his debt to her, Wessels had his goods attached. ${ }^{108}$

In November 1659, Wessels was a defendant in a case in which she was accused of killing and butchering a hog prior to having the hog's value assessed by the farmer of the excise, i.e., tax assessor. She reported that on the day the hog was killed and butchered she had sent her daughter, Mary, to find the farmer of the excise to report the value of the animal. However, Mary was unable to find the farmer of the excise. After some discussion by the magistrates, Wessels offered to prove she had attempted to report the value of the hog. The Court of Burgomasters and Schepens of New Amsterdam ordered her to do so on the next court day. ${ }^{109}$ These are only two examples of Wessels appearances in court during her marriage to Wesselszen. Prior to the death of her husband, Wessels appeared as a defendant or plaintiff in civil suits in the Court of Burgomasters and Schepens of New Amsterdam on at least nineteen occasions. ${ }^{110}$

Wessels' court appearances did not diminish after the death of her husband. She used experiential knowledge gained from previous court appearances to bring about

${ }^{108}$ RNA 2: 345 .

${ }^{109}$ Ibid., 3: 81. This case against Wessels does not appear in the records on the next or subsequent court days, leading to the conclusion it was dropped by the farmer of the excise.

${ }^{110}$ Ibid., 1-3: passim. 
successful litigation on many occasions during widowhood. For the ten months remaining in 1661 following the death of her husband, Wessels was involved in litigation no fewer than 27 times. ${ }^{111}$ In the vast majority of cases, 22 times, Wessels was the plaintiff. In 17 of the cases in which she appeared as a plaintiff, the cases were continued owing to default by the defendants or requests by the defendants for continuances. In one important case in which she was a defendant, Wessels retained the seized accounts of Reyndert Jansen Hoorn, who had absconded. Represented in this case by counsel, Thielman van Vleeck, she maintained her claims against Hoorn's assets had priority over those of other creditors. ${ }^{112}$ Attorneys for the other creditors, Govert Loockermans and Jacobus Backer, continued to pursue release of Hoorn's assets. Unfortunately for Wessels, the Court of Burgomasters and Schepens eventually ruled in favor of Loockermans and Backer. ${ }^{113}$ Nevertheless, with the help of van Vleeck, she was able to delay the decisions for five months. That is, she eventually received a share of Hoorn's assets, but tenaciously fought to retain the full amount owed to her.

The experience of widowhood for Annetje Dircx was not unique among Dutch women in New Netherland, but it was anomalous. Dircx entered marriage with Pieter Kock against her will. She rescinded her initial promise to marry Kock. Unfortunately,

${ }^{111}$ Ibid., 3: 249-429, passim. Based on the power of attorney she gave to Thielman van Vleck, a notary public, to collect outstanding debts due her deceased husband, it appears Wessels Wesselszen died in February 1661. Register of Salomon Lacharie, 7.

$$
\begin{aligned}
& { }^{112} R N A, 3: 266 . \\
& { }^{113} \text { Ibid., 317-319. }
\end{aligned}
$$


Dircx made the promise in the presence of witnesses. Owing to a superior legal position, Kock persisted in his efforts through legal action in the Court of Burgomasters and Schepens of New Amsterdam. Evidence of Kock's persistence is recorded in the minutes of that court where he appeared or was represented fifteen times between February 1653 and May 1654 in his efforts to secure legal recognition of his marriage to Dircx. ${ }^{114}$ Despite her efforts, Dircx was eventually required by the Court of Burgomasters and Schepens to marry Kock. ${ }^{115}$

Dircx experienced more than legal disadvantages when she sought release from her marriage agreement. In addition, she experienced the effects of these disadvantages for most of her life, including the period after the death of her husband. Dircx was among the minority of women in New Netherland who were illiterate. A year after the death of Kock in 1661, Dircx sold 25 morgans (approximately 50 acres) to Henrick Jansen Spieringh. ${ }^{116}$ She acknowledged the sale with her mark, indicating she probably could not write. Presence of a mark rather than a signature is neither absolute proof of an inability to write nor proof Dircx was unable to read. Nevertheless, those conclusions are indicated by her use of others to assist her when she appeared in court. For example, when she was struggling for release from her marriage contract with Kock, she was represented by her step-father, Jacob Stoffelsen. On other occasions she was

\footnotetext{
${ }^{114}$ Ibid., 1: passim.

${ }^{115}$ Ibid., 199-200.

${ }^{116}$ Minutes of the Orphanmaster's Court, 2: 28-29.
} 
represented by notary David Provoost. ${ }^{117}$

Dircx does not appear in court records during her marriage to Pieter Kock.

While illiteracy may have been an important factor in her non-appearance in court, Dircx was nevertheless in the minority of women who did not share legal responsibilities with their husbands.

In addition to lack of court experience that may have better informed her about the requirements of law, another difficulty experienced by Dircx during much of her life was impoverishment. Soon after the death of Kock, lack of legal knowledge combined with poverty to cause problems greater than she was able to resolve. In February 1661, she contracted with carpenters Willem Abrahamsen van der Borde and Deonys Isaaksen van Hartoghvelt to build a house. ${ }^{118}$ The contract was very specific about the details of the house, including the roof, two cellars, doors, and even, "two planed transom window frames with sashes and glass." 119 In light of her illiteracy, that much detail implies she may have had assistance in making the contract. ${ }^{120}$ However, she may have been aware of some of the details owing to existence of an earlier contract between her late husband and other carpenters who had been hired to build the house.

${ }^{117}$ For Stoffelsen's role see, Ibid., 1: 54, 64, 80. Provoost appears in the records on three occasions. Ibid., 150, 154, 163.

${ }^{118}$ Goodfriend, “"Too Great a Mixture of Nations'," 57-58, provided detailed information about the life of van Hartoghvelt and his wife and children.

${ }^{119}$ Register of Salomon Lacharie, 15.

${ }^{120}$ Ibid., 14-15. The contract was drawn up by Lacharie and witnessed by two people who, for unexplained reasons, were not named in the document or required to sign it. 
Existence of the earlier contract came to light when the carpenters, Robbert Roelantsen and Abraham Janzen, brought suit against Dircx. ${ }^{121}$ The carpenters requested the court to uphold their contract and therefore nullify the later contract between Dircx and van der Borde and van Hartoghvelt. Showing ignorance of the law of contracts, Dircx maintained the earlier contract was made void by the death of her husband and she was free to contract independently with others. ${ }^{122}$ Without knowledge of law drawn from previous experience and having no one to assist her in the matter, Dircx was not aware of the validity of the earlier contract. ${ }^{123}$ After hearing the arguments, the Court of Burgomasters and Schepens ordered Dircx to follow the terms of the original contract. ${ }^{124}$

Unfortunately for Dircx, the parties to receive the contract were irrelevant. She could not pay them. In September 1661, Roelantsen and Janzen sued Dircx for twelve and one half beavers of outstanding installment debt on the house they were building for

${ }^{121}$ It is assumed when Lacharie, who was trained at law, drew up the contract between Dircx and van der Borde and van Hatoghvelt, he was unaware of the earlier contract between Kock and Roelantsen and Janzen.

${ }^{122} R N A, 3: 310$.

${ }^{123}$ Referring to contracts, Grotius explained, "Contract we have previously described in terms of natural law; from which it may be understood that a mere declaration or even promise which is not made with the intention that it shall be accepted or which is not in fact accepted confers no right: but promises made in God's honour, or from antecedent causes for the honour of the country or of a city, are deemed in law to be accepted contract, so that even the heir (who generally is not bound by his ancestor's mere promises) may be sued upon them." Jurisprudence of Holland, 305.

${ }^{124} R N A, 3: 310$. Specifically, the magistrates ordered Dircx to allow Roelantsen and Janzen to build the house or, if not, to pay them according to the contract. 
her. ${ }^{125}$ Dircx reported she offered the carpenters half that amount in partial payment, but they refused. The record does not indicate that the magistrates considered either Dircx's widowed state or her responsibilities as a parent. ${ }^{126}$ They ordered the full amount plus court costs paid.

However, Dircx's inability to pay the full amount implied poverty. One reason the magistrates may have ruled against Dircx was because she had assets about which she may have been ignorant. Her late husband was not a stranger to litigation and was often successful in protecting his financial interests. ${ }^{127}$ More significantly, after an Indian attack in 1655, Director General Stuyvesant and the colonial council mandated contributions from New Amsterdam property owners for improvement of defenses. The resolution required property owners to contribute voluntarily or through taxation. ${ }^{128}$ The taxation of Pieter Kock was 20 florins, which was the same as the contribution made by carpenter and neophyte merchant, Frederick Flipsen (Frederick Philipse). ${ }^{129}$ The least paid was 4 florins and the most was 150 florins. The average, dispersed over 210 burghers, was 30 florins. Based on this limited information, it appears Kock was neither wealthy nor impoverished. Therefore, ignorance as result of lack of court

${ }^{125}$ Ibid., 364.

${ }^{126}$ She had at least one child by Kock. See appointment of guardians, Records of the Orphanmaster's Court, 1: 160.

${ }^{127} R N A, 1$ : passim.

${ }^{128}$ Ibid., 366-367.

${ }^{129}$ Ibid., 371. Flipsen or Philipse was not as wealthy in 1655 as he would become in subsequent years after his marriage to Margaret Hardenbroeck. 
experience and apparently little familiarity with her family's financial accounts caused Dircx greater difficulty than either her illiteracy or ostensible poverty.

However, although the circumstances of widowhood forced Dircx to take more responsibility than she was accustomed to during her marriage, she soon learned ways to protect her interests. On February 18, 1662, she appeared in the Court of Burgomasters and Schepens of New Amsterdam in a case involving Abraham Pieters[en] Corbyn, who was incarcerated for theft. Corbyn denied commercial dealings with Dircx that, according to her, included an exchange of livestock and unnamed goods. Dircx produced an account of the transactions and offered details which Corbyn could not refute. However, the magistrates denied Dircx payment from Corbyn, maintaining the amount she charged was exorbitant. ${ }^{130}$ Nevertheless, her presentation of documents showed an increased level of awareness of legal requirements. Specifically, she was more aware of the need to support her verbal assertions.

In May 1662, Dircx was summoned to the Orphanmaster's Court about an outstanding debt to the estate of Sicx van der Stighlen. She reported the amount she owed (four beavers), called in a witness to confirm it, and gave an oath as to the accuracy. ${ }^{131}$ Then, in July 1663 , ostensibly to acquire an outstanding debt owed to her, Dircx petitioned the Council of New Netherland for an inventory of the property of John de Smet of Westchester. Her petition was granted. ${ }^{132}$ Admittedly, court records do not

\footnotetext{
${ }^{130}$ Ibid., 4: 34-36.

${ }^{131}$ Records of the Orphanmaster's Court, 2: 139.

${ }^{132}$ Council Minutes, 1: 250.
} 
reflect intense legal activity by Dircx during widowhood. She appears in court records in only six separate actions. ${ }^{133}$ Nevertheless, her success in the two examples above compare favorably to her earlier lack of success. The implication is that she learned from her earlier failures. She was able to do so owing to the virtually universal conditions of widowhood that forced women into added responsibilities that many found difficult. This was particularly so while they were grieving the loss of their husbands. However, Dircx's cultural heritage was also an important factor owing to easy acceptance of women in roles as financial managers and family representatives in public forums like court.

Nevertheless, Dircx and other Dutch widows in New Netherland shared some characteristics with others in colonial America. Like most widowed women in other areas of colonial America, widowed Dutch women in New Netherland were thrust into unwelcome arenas of responsibility during a period of mourning. Further, widowed women with children were expected to assume added burdens without diminution of their unique role as mothers. That is, regardless of other responsibilities, motherhood was paramount. Also like many other colonial American widows, most Dutch widows handled the responsibilities of widowhood with determination to overcome their difficulties. In a sex-skewed population advantageous to women, the clearest avenue of relief from added hardship for widows in New Netherland and elsewhere was a second, and for some, a third or fourth marriage. Finally, like widowed women in other

${ }^{133}$ The unmentioned action was in relation to the building of her house. The council refused to allow her to have a house built in the lot for which she applied owing to its nearness to the fort. Ibid., 223. 
colonies, widowed New Netherland Dutch women with wealth and elite status experienced enhanced advantages and vulnerabilities.

Regardless of all the similarities with other widowed women in early America, the experience of widowed Dutch women was also unique. Technically, Dutch laws severely restricted the proprietary interests of wives and their ability to represent themselves and families in public forums. That is, they were legally limited in their ability to represent their families in court and in their proprietary capacities because they were assigned the status of sub tutela or minority status under the control of their husbands. ${ }^{134}$ Strict adherence to these laws by the Dutch in earlier centuries is equivocal. Laws that severely limited the legal capacities of wives were clearly antiquated by the progress of the commercial revolution and Protestant Reformation in the sixteenth and seventeenth centuries. ${ }^{135}$ Consequently, Dutch wives acquired responsibilities uncommon for most women in Western Europe. The combination of social acceptance of enhanced roles for wives and practice of uncommon responsibilities created an atmosphere that allowed many Dutch women to successfully assert prerogatives during widowhood.

This does not imply Dutch women found widowhood less painful or overwhelming than did women in other cultures. The letters of widows like Maria van Rensselaer and more significantly, court records of widows like Rachel van Tienhoven,

${ }^{134}$ Although laws governing wives' position were similar among the various Dutch provinces, this statement refers specifically to Holland. Grotius, Jurisprudence of Holland, 29-33.

${ }^{135}$ Narrett, Inheritance and Family Life, 43. 
Metje Wessels, and Annetje Dircx indicate widows' assumption of responsibilities formerly shared with their husbands was often staggering. The responsibilities of parenthood further complicated their condition. While rare, instances of widows' abdication of debts accumulated during marriage through renunciation did occur. ${ }^{136}$ One reason for the rarity of abdication of rights to their estates may have been because of the qualification that renunciation could not occur in the circumstance of,

"women-traders, who in the presence or in the absence of their husband have publically intermeddled with the trade-transactions in the selling or buying of merchandise, for they are bound to answer for their husbands' debts." 137

Inasmuch as New Netherland was a product of the Dutch golden age of commerce and many women participated in trade, formal renunciation may not have been an option for many.

However, another reason why many widowed women did not renounce their debts were the responsibilities of partnership marriage. Dutch society in seventeenthcentury America (and the United Provinces) refuted the patriarchal conservatism of Dutch laws that governed the activities of women. Nevertheless, as authors like Linda Biemer, David Narrett, and Deborah Rosen, and others have shown, during the last decade of the seventeenth century English acculturation affecting women was easily

${ }^{136}$ Shattuck, "A Civil Society," 174-175. Widows could turn their estate over to the courts for administration or make a formal public renunciation of community property. Grotius, Jurisprudence of Holland, 123, referred to the latter as boedelafstand; literally, "abdication of estate."

${ }^{137}$ Ibid. 
recognizable. ${ }^{138}$ Exhaustive research of New York wills by historians like David Narrett has evinced the declining role of widows in the social and economic life of late seventeenth and eighteenth century New York. ${ }^{139}$ As English acculturation moved women to the periphery of economic activity, families grew less dependent on wives and mothers for financial management and public advocacy. Therefore, particularly as the eighteenth-century progressed, unless wives were merchants and possessed legal status as femme sole trader, they were less likely to bring experiential knowledge into widowhood.

It is difficult to measure widows' independence in the late seventeenth and eighteenth centuries in New York. As the influence of English culture increased in New York society, criminal and testamentary court appearances by women outnumbered their appearances in civil litigation suits. ${ }^{140}$ Therefore, in relation to widows, historians have

${ }^{138}$ Biemer, Women and Property; Narrett, Inheritance of Family Life, Rosen, "Mitigating Inequality,"; Courts and Commerce; Salmon, Women and the Law of Property; Gundersen and Gampel, "Married Women's Legal Status in EighteenthCentury New York and Virginia." Acculturation came about through a variety of subtle yet pervasive legal and social conveyances, including ascent of English common law, a gradually increasing ratio of people with English heritage, and development of a powerful commercial elite anxious to gain the benefits of cooperation with English authorities. See, Goodfriend, "Too Great a Mixture of Nations"”; and Maika, "Commerce and Community."

${ }^{139}$ Narrett, Inheritance and Family Life; "Men's Wills and Women's Property Rights in Colonial New York," in Ronald Hoffman and Peter J. Albert, eds. Women in the Age of the American Revolution (Chapel Hill, 1989), 91-133.

${ }^{140}$ Biemer, Women and Property, 7-9; "Criminal Law and Women in New Amsterdam and Early New York," in Zeller, ed. A Beautiful and Fruitful Place, 73-82. 
given greater attention to changing testamentary practices. ${ }^{141}$ The process was gradual, but over time Dutch practices that influenced women's roles were replaced by practices influenced by English culture.

Widows in every period of American history have had unwelcome and often overwhelming legal and social responsibilities thrust upon them. Given the experiential knowledge gained by Dutch women in New Netherland during marriage, most were better prepared for widowhood than was the case for later generations of New York women. Many historians have written about the circumscriptive and sometimes misogynistic character of early American patriarchy that affected all classes of women throughout the stages of life. ${ }^{142}$ Therefore, I conclude, the ascent of English culture in New York represented a regression in efficient management of the financial and legal affairs of a major segment of the New York population. From Dutch cultural foundations that recognized value in women as widows, as the colony acculturated to English expressions of gender roles for women New Yorkers deprived themselves of valuable sources of experience, knowledge, and talent.

\begin{abstract}
Afterword
Madaleena Blansjan, Plaintiff, vs. Allert Heymansen, Defendant: Plaintiff demands of defendent a sum of $7 \mathrm{sch}$.[epels] of whea $t$ for having instructed their daughter in knitting, and they made a verbal agreement that they were to pay as much as she was
\end{abstract}

${ }^{141}$ This was the basis for the work of Marylynn Salmon, Women and the Law of Property in Early America, xiii.

${ }^{142}$ The list of sources for this approach to the history of American women is extensive. Therefore, the works are included in the bibliography. 


$$
\text { paid by others ..." }
$$

English expropriation of New Netherland inaugurated a period of change for American Dutch women that is more recognizable as a historical phenomenon that it was when it occurred. Gradual anglicization of law that culminated in application of common law in most areas of the colony following Leisler's Rebellion is one explanation for the development. ${ }^{2}$ Patriarchally conservative English common law that denied specifically wives' interest in property is one of the most historically recognizable changes for Dutch women in New York. ${ }^{3}$ Wider use of common law in New York, under which wives were subsumed, grew from the perceived need to exert greater imperial authority in New York in the wake of Leisler's Rebellion.

One reason changes for Dutch women in New York are more historically evident was that domesticity formed the foundation of Dutch women's roles in New Netherland. The records indicate under Dutch law and custom, women had significant

${ }^{1}$ Kingston papers, 1: 426-427.

${ }^{2}$ Narrett, "Men's Wills and Women's Property,” 105.

${ }^{3}$ Codification of common law after Leisler's Rebellion came about partly because of the amorphous condition of jurisprudence in the colony. Codification gave the law tangibility that pleased most colonial jurists and litigants. However, the ascent of common law in New York was part of a larger movement that emphasized English common law all of Britain's colonies in America. Friedman, History of American Law, 90-93. Although not written until the eighteenth-century, Sir William Blackstone, Commentaries on Laws of England, 4 vols. (Oxford, 1765-1769), 1: 442, quoted and discussed in Ulrich, Good Wives, 7, described marriage for women as, "the very being or legal existence of the woman is suspended during marriage, or at least incorporated into that of the husband; under whose wing, protection, and cover, she performs everything." 
responsibilities for the welfare of their families. It is difficult to know the extent of women's responsibilities in colonies founded by English colonists because women did not often represent their families in public forums like court proceedings. Nevertheless, Dutch women's appearances in court and commerce grew out of their roles as wives and mothers. After England expropriated New Netherland, many Dutch wives were denied public responsibilities for the welfare of their families. Therefore, it is important to qualify Dutch women's public activities as an expression of domesticity rather than independence.

The energies of women were not completely turned inward toward home and hearth in the seventeenth and eighteenth centuries. Women remained commercially active as widows, through implied or actual legal exceptions like status as femme sole trader, and sometimes extralegally. Women's involvement in Leisler's Rebellion is seen by some historians as an expression of Dutch women's frustration with increased circumscription. ${ }^{4}$ However, even in that much debated event, women's participation was defined by family and connections of affinity and finance.

One important consequence of common law ascendance in New York was cessation of legal divorce and separation. Recognized legally as a civil function under Dutch and Puritan law, marriage was redefined by provincial English administrators seeking to introduce English jurisprudence and customs to a foreign population. Therefore, marital dissolutions were continued for a brief time during the colony's

\footnotetext{
${ }^{4}$ Voorhees, "'how ther poor wives do, and are delt with"”; Burrows and Wallace, Gotham, 93.
} 
proprietary period. Nevertheless, despite legal availability under Dutch law and women's autonomy to act independently for the benefit of their families, dissolutions seldom occurred under Dutch and early English administrations.

The most evident characteristic of Dutch women in New Netherland and New York in the seventeenth century was their dedication to their families. When they appeared in public proceedings as principal participants in litigation and commerce, women most often did so as members of nuclear and extended families.

Historians have long debated the relative circumscription of early American women, particularly seventeenth-century women. That debate has largely focused on women in colonies initially founded by England. The premises that formed the debate over early American English women helped establish the grounds for a discussion of Dutch women in New Netherland and New York in the seventeenth century. Specifically, law has provided many paradigms for measuring relative circumscription or diminution of circumscription of early American English women. Similarly, historians of early American Dutch women have depended on the Roman-Dutch founded law of Grotius and van Leeuwen to establish a foundation for their investigations. While Roman-Dutch law provided particularly married women with freedom of action in areas seldom afforded women under English common law, it also placed limits on their independence. That is, Dutch law assumed marriage and motherhood were the primary roles of women.

In 1930, Richard Morris built upon and added substance to the assertions of Elizabeth Dexter about the condition of women in particularly seventeenth-century 
America. Morris indicated marriage in seventeenth-century America was, "a reciprocal agreement (that) materially helped to raise women from the state of legal

subordination."5 Morris related the severity of particularly English common law was militated by economic and social conditions of colonial American life. ${ }^{6}$ More recent authors have challenged Morris' premise. In their studies of early American women, scholars like Mary Beth Norton, Kathleen M. Brown, and others have found the patriarchal social formation of seventeenth-century England consistent with life in early America. They offer sectional differences between the Chesapeake and New England, but imply separate spheres based on gender, with domesticity being dominant for women. $^{7}$

The studies indicated above that challenged the premises of Dexter and Morris asserted generalizations based on English cultural background and region. Seventeenth-

${ }^{5}$ Morris, Studies in the History of Early American Law, 127; Dexter, Colonial Women of Affairs.

${ }^{6}$ Ibid., 126. Herbert Moller, "Sex Composition and Correlated Cultural Patterns of Colonial America," WMQ, $3^{\text {rd }}$ ser. no.2 (1945), 113-153; Mary Ritter Beard, Women as a Force in History (New York, 1946), resounded Morris' thesis. Moller showed a skewed sex ratio in colonial America contributed to greater responsibilities and opportunities for women.

${ }^{7}$ Linda Kerber, Women of the Republic: Intellect and Ideology in Revolutionary America (Chapel Hill, 1980), 7; Lyle Koehler, A Search for Power: "The Weaker Sex in Seventeenth-Century New England (Urbana, Ill., 1980); Norton, "The Evolution of White Women's Experience in Early America," American Historical Review, vol. 89, no.3 (June, 1984), 593-619; and, Founding Mothers and Fathers; Carol K. Karlson, The Devil in the Shape of a Woman: Witchcraft in Colonial New England (New York, 1987); Gloria Main, "Gender, Work, and Wages in Colonial New England, WMQ, vol. 51, no.1 (January, 1994), 39-66; Brown, Good Wives, Nasty Wenches, and Anxious Patriarchs. 
century New England and the Chesapeake colonies have received disproportionate historiographic attention. For example, Morris used many court cases from New Netherland to support his thesis about the autonomy of early American women. No author who has challenged Morris' thesis has recognized that fact and given attention to the contributions of the Dutch.

In reality, every early American woman for whom we have records was unique. ${ }^{8}$ Scholarship in the history of early American women has reached a stage of development that shows need to recognize the diversity of cultural models of patriarchy and gender. Gender defined life for women and men in early America, but so did status, family, labor, and ethnicity. Studies using these foci are prolific, but most often are based on English culture.

Owing to his use of New Netherland and early New York court records, it is not surprising that Richard Morris found greater flexibility for particularly married women in early America. His reciprocity thesis of marriage in seventeenth-century America very well described early American Dutch marriages. Nevertheless, his work did not explore the Dutch foundations of partnership marriage in the middle colonies.

From the moment England expropriated New Netherland, English cultural ascendance began. Nevertheless, the process was not sudden, uniform, or comprehensive. Although it is difficult to measure sociologically, elements of Dutch culture continued to influence the development of colonial New York society for many years after the colony became an English possession. The influence of Dutch

\footnotetext{
${ }^{8}$ Perhaps the best example of this was related by Ulrich, A Midwife's Tale.
} 
inhabitants is more evident in the political and commercial history of the colony, particularly in factional alignments following Leisler's Rebellion. For historians of early American women, one problem with public documents like court records influenced by English law is women were often written out. In addition, absence of newspapers and diaries and sparcity of correspondence compounds the problem.

Owing to Dutch influence, inclusion of women in the court records of New Netherland and New York in the seventeenth century is prolific. Therefore, those records offer uncommon opportunities for learning about ways early American women interacted with their families, each other, their neighbors, and their physical environment. The majority of women in the records were of Dutch descent, but other cultures were represented as well. Many of the others had become acculturated by living in the Netherlands prior to emigration to New Netherland. Anyway, they were living in Dutch culture and under Dutch law. Study of seventeenth-century American Dutch and Dutch acculturated women invites greater inclusion of women from every culture who helped shape early American life. Moreover, greater emphasis on women's contributions adds greater depth, breadth, and accuracy to early American history. 


\section{Bibliography}

\section{Primary sources: Collections}

Leisler Papers, New York University, (excerpts courtesy of David William Voorhees).

Melyn Letter Book, American Antiquarian Society, Worcester, MA., (excerpts courtesy of David William Voorhees).

\section{Published Primary Sources}

Andrews, Charles, ed. Narratives of the Insurrections, 1675-1690. New York: Barnes and Noble, 1959.

Bredero, Gerbrand. The Spanish Brabanter. ed. and trans. David Brumble, III. Binghamton: State University of New York, 1981.

Cats, Jacob. Huwelijck. comp. Agnes Sneller. Amsterdam: Em. Quirido's Uitgeverij, 1993.

Christoph, Peter R., Kenneth Scott, and Kenn Stryker-Rodda. New York Historical Manuscripts: Dutch, Kingston Papers, 2 vols. Baltimore: Genealogical Publishing, 1976. and Florence A. Christoph, eds. New York Historical Manuscripts, English: Records of the Court of Assizes for the Colony of New York, 1665-1682. Baltimore: Genealogical Publishing, 1983.

Corwin, E.T. Ecclesiastical Records of the State of New York. 7 vols. Albany: James B. Lyon, 1901-1916.

Denton, Daniel. A Brief Description of New York: Formerly Called New-Netherlands With Places thereunto Adjoining. ed. Gabriel Furman. New York, 1845.

Fernow, Berthold, ed. Records of New Amsterdam, 1664-1674. 7 vols. Baltimore: Genealogical Publishing, 1976. Minutes of the Orphanmaster's Court of New Amsterdam, 1652-1663. 2 vols. Albany: Harper, 1907.

Filmer, Robert. Patriarcha and Other Political Works. ed. Peter Laslett. Oxford: Oxford University Press, 1949. 
Fox, Dixon R., ed. Minutes of the Court of Session, Westchester County, 1657-1696. New York: Barnes and Noble, 1924.

Gehring, Charles T. and Nancy Anne McClure Zeller, eds. Education in New Netherland and the Middle Colonies: Papers of the $7^{\text {th }}$ Rensselaerwyck Seminar of the New Netherland Project. Albany: New Netherland Project, 1985. , trans. and ed., Fort Orange Court Minutes 1652-1660. Syracuse: Syracuse University Press, 1990. , trans. and ed.,"Correspondence of Pieter Stuyvesant.” New Netherland Document Series. 11 vols. Syracuse: Syracuse University Press, 2000.

Grotius, Hugo (Hugo de Groot). Jurisprudence of Holland. trans. R.W. Lee. Oxford: Clarendon Press, 1926.

Hanlin, Paul M. and Charles E. Baker, eds. Annotated Minutes of the Supreme Court of Judicature of the Province of New York, 1691-1724. 3 vols. New York: Barnes and Noble, 1959.

Heywood, Thomas. Pleasant Dialogues and Dramas. London: vaduz, 1637; reprint, Louvain:Kraus, 1963.

Irwin, Susan L. ed. and trans. Anna Maria van Schurman: Whether a Christian Woman Should Be Educated, and other writings from her intellectual circle. Chicago: University of Chicago Press, 1998.

Ivatt, Albert, ed. The Memoirs and Travels of Sir John Reresby, Bart., 1634-1689. Cambridge: Cambridge University Press, 1904.

Lincoln, Charles Z. ed., The Colonial Laws of New York from the Year 1664 to the Revolution. 5 vols. Albany: Rochester, N.Y.: J.B. Lyon, 1896.

Jameson, J. Franklin, ed. Narratives of New Netherland, 1609-1664. Reprint. New York: Barnes and Noble, 1937.

Minutes of the Common Council of the City of New York, 1675-1866. 8 vols. New York: Dodd, Mead and Company, 1905.

Moryson, Fynes. An itinerary containing his ten yeares travell through the twelve dominions of Germany, Bohmerland, Sweitzerland, Netherland, Denmarke, Poland, Italy, Turky, France, England, Scotland \& Ireland. New York: Macmillan, 1907-1908. 
Murphy, Henry C., ed. Journal of a Voyage to New York and a Tour in Several American Colonies in 1679-1680 by Jasper Dankers and Peter Sluyter. Ann Arbor: UMI, 1966.

O'Callaghan, Edmund B., ed. Documents Relative to the Colonial History of the State of New York. 11 vols. Albany: Weed, Parsons and Company, 1853-1887. Laws and Ordinances of New Netherland, 1638-1674. Albany: Weed, Parsons and Company, 1868.

History of New Netherland or New York Under the Dutch. 2 vols. New York: D. Appleton, 1848.

The Register of New Netherland, 1626-1674. Albany: J. Munsell, 1865.

O'Callaghan, Edmund B., trans. Documentary History of the State of New York. 4 vols. Albany: Weed, Parsons, 1868.

Paltsits, Victor H., ed. Minutes of the Executive Council of the Province of New York: Administration of Francis Lovelace, 1668-1673. 2 vols. Albany: State of New York, 1910.

Pearson, Jonathan, trans. A.J.F. van Laer, rev. and ed. Early Records of the City and County of Albany, 1654-1678. 4 vols. Albany: J. Munsell, 1916-1919.

"Petition to the King to Reverse the Attainders." vol. I, 1665-1707, in New-York Historical Society Collections, New York: 1868: 336-337.

"Petition of Widow Leisler, Her Son and Six Daughters." vol. I, in New York Historical Society Collections, New York: 1868: 335-336.

Purple, Edwin R. Records of the Reformed Church in New Amsterdam and New York. New York: 1890.

"Records of the Reformed Church in New Amsterdam/New York-Marriages." New York Genealogical and Biographical Record.

Scott, Kenneth, ed. Minutes of the Mayor's Court of New York, 1674-1675. Baltimore: Genealogical Publishing, 1983.

Scott, Kenneth, comp. New York City Court Records, 1684-1760: Genealogical Data from the Court of Quarter Sessions. Washington, D.C.: National Genealogical Society, 1982. 
Stokes, I.N.P. ed. Iconography of Manhattan Island, 1498-1909. 6 vols. New York: Robert H. Dodd, 1915-1928.

Temple, William. Observations Upon the United Provinces of the Netherlands. ed. George Clark. Oxford: Oxford University Press, 1972.

Van Beverwijck, Jan. Uitnementhyt de Vroulicken. Dordrecht: 1643.

Van der Donck, Adriaen. A Description of New Netherlands. ed. Thomas F. O’Donnell. Syracuse: Syracuse University Press, 1968.

Van Laer, A.J.F., trans. and ed. Correspondence of Jeremias van Rensselaer, 16511674. Albany: University of the State of New York, 1932.

Correspondence of Maria van Rensselaer, 1669-1689. Albany: University of the State of New York, 1935.

Minutes of the Court of Albany, Rensselaerwyck, and Schenectady, 1680-1685. 3 vols. Albany: University of the State of New York, 1926-1932.

Minutes of the Court of Fort Orange and Beverwyck, 1652-1660. 2 vols. Albany: University of the State of New York, 1920-1923.

The Van Rensselaer Bowier Manuscripts. Albany: University of the State of New York, 1908.

Van Leeuwen, Simon. Commentaries on Roman-Dutch Law. ed. C.W. Decker. trans. J.G. Kotze. London: Printed by command of His Majesty's secretary of state for the Department of war and of colonies, 1921.

Wooley, Charles. A Two Years Journal in New York and Part of Its Territories in America. Cleveland: Burrows Brothers, 1902.

\section{Secondary Sources: Books}

Beard, Mary Ritter. Women as a Force in History: A Study in Traditions and Realities. New York: Macmillan, 1946.

Becker, Carl L. The History of Political Parties in the Province of New York, 17601776. Madison: University of Wisconsin., 1909. 
Berkin, Carol. First Generations: Women in Colonial America. New York: Hill and Wang, 1996.

Biemer, Linda B. Women and Property in Colonial New York: The Transition from Dutch to English Law, 1643-1727. Ann Arbor: UMI, 1983.

Black, H.C. Black's Law Dictionary. St. Paul, MN.: West, 1990.

Bonomi, Patricia U. A Factious People: Politics and Society in Colonial New York. New York and London: Columbia University Press, 1971.

Booth, Mary L. History of the City of New York From Its Earliest Settlement to the Present Time. New York: W.R.C. Clark \& Meeker, 1858.

Brown, Kathleen M. Good Wives, Nasty Wenches, and Anxious Patriarchs: Gender, Race, and Power in Colonial Virginia. Chapel Hill: University of North Carolina Press, 1996.

Buckland, William Warwick. A Manual of Roman Private Law. Cambridge: Cambridge University Press, 1953.

Roman Law and Common Law: A Comparison in Outline. Cambridge: Cambridge University Press, 1936; Reprint, William W. Gaunt and Sons, 1994.

Clark, Alice. The Working Life of Women in the Seventeenth-Century. Reprint, London: Routledge, 1992.

Clark, Christopher. Roots of Rural Capitalism: Western Massachusetts, 1780-1860. Ithaca: Cornell University Press, 1990.

Cohen, David Steven. The Dutch-American Farm. New York: New York University Press, 1992.

Condon, Thomas J. New York Beginnings: The Commercial Origins of New Netherland. New York: New York University Press, 1968.

Cowen, Ruth Swartz. More Work for Mother: The Ironies of Household Technology from the Open Hearth to the Microwave. New York: Harper Collins, 1983.

Deetz James. In Small Things Forgotten: The Archaeology of Early American Life. Garden City, N.Y.: Doubleday, 1977. 
Dexter, Elizabeth. Colonial Women of Affairs: Women in Business and the Professions in America Before 1776. New York: Houghton, 1931.

Fabend, Firth Haring. A Dutch Family in the Middle Colonies, 1660-1800. New Brunswick: Rutgers University Press, 1991.

Faragher, John Mack. Women and Men on the Overland Trail. New Haven: Yale University Press, 1979.

Fischer, David Hackett. Albion's Seed: Four British Folkways in America. New York: Oxford University Press, 1989.

Fiske, John. The Dutch and Quaker Colonies in America. 2 vols. Boston: Houghton Mifflin, 1901.

Franits, Wayne. Paragons of Virtue: Women and Domesticity in Seventeenth-Century Dutch Art. New York: Cambridge University Press, 1993.

Franz, Carol E. and Abigail J. Stewart, eds. Women Creating Lives: Identities, Resilience, and Resistance. Oxford: Oxford University Press, 1994.

Fraser, Antonia. The Weaker Vessel. New York: Knopf, 1984.

Friedman, Lawrence M. A History of American Law. New York: Simon and Schuster, 1985.

Gehring, Charles T. A Guide to Dutch Manuscripts Relating to New Netherland in United States Repositories. Albany: State University of New York, 1978.

Goodfriend, Joyce D. Before the Melting Pot: Society and Culture in Colonial New York City, 1664-1730. Princeton: Princeton University Press, 1992.

Greven, Philip J. Four Generations: Population, Land, and Family in Colonial Andover, Massachusetts. Ithaca: Cornell University Press, 1970.

Guide to Records in the New York State Archives. Albany: University of the State of New York and The State Education Department of State Archives and Records Administration, 1993.

Hackett, David G. The Rude Hand of Innovation: Religion and Social Order in Albany, New York, 1652-1836. New York: Oxford University Press, 1991. 
Haks, Donald and Maria Christine van der Sman. eds. Dutch Society in the Age of Vermeer. trans. Wendie Shaffer. Zwolle: Waanders Publishers, 1996.

Haks, Donald. Huewlijck en Gezin in Holland in de 17de and 18de eeuw:

Processtukken en moralisten over aspecten van het zeventiede-en achttiende-eeuwse gezinleven. Assen: Verloren, 1982.

Haley, K.H.D. The British and the Dutch: Political and Cultural Relations Through the Ages. London: Butler and Tanner, 1988.

Hill, Christopher. The Century of Revolution, 1603-1714. New York: Norton, 1980.

Hoffer, Peter C. Law and People in Colonial America. Baltimore: The Johns Hopkins University Press, 1992.

Hoffman, Ronald and Peter J. Albert. eds. Women in the Age of the American Revolution. Chapel Hill: University of North Carolina Press, 1989.

Israel, Jonathan I. The Dutch Republic: Its Rise, Greatness, and Fall, 1477-1806. Oxford: Oxford University Press, 1995.

Jensen, Joan M. Loosening the Bonds: Mid-Atlantic Farm Women, 1750-1850. New Haven: Yale University Press, 1986.

Judd, Jacob, and Irwin H. Polishook. Aspects of Early New York Society and Politics. Tarrytown, N.Y.: Sleepy Hollow Restorations, 1974.

Kammen, Michael. Colonial New York: A History. New York: Scribners, 1975.

Karlsen, Carol K. The Devil in the Shape of a Woman: Witchcraft in Colonial New England. New York: Norton, 1987.

Kemp, William Webb. The Support of Schools in Colonial New York by the Society for the Propagation of the Gospel in Foreign Parts. New York: Arno Press, 1969.

Kenney, Alice P. The Gansevoorts of Albany: Dutch Patricians in the Upper Hudson Valley. Syracuse: Syracuse University Press, 1969.

Kerber, Linda K. and Jane Sherron De Hart, eds. Women's America: Refocusing the Past. New York: Oxford University Press, 1995. 
Kerber, Linda K. Women of the Republic: Intellect and Ideology in Revolutionary America. Chapel Hill: University of North Carolina Press, 1980.

Kermode, Jenny and Garthine Walker, eds. Women, Crime and the Courts in Early Modern England. Chapel Hill: University of North Carolina Press, 1994.

Kierner, Cynthia. Traders and Gentlefolk: The Livingstons of New York, 1675-1790. Ithaca: Cornell University Press, 1992.

Kilpatrick, William Heard. The Dutch Schools of New Netherland and Colonial New York. New York: University Press, 1969.

Kim, Sung Bok. Landlord and Tenant in Colonial New York: Manorial Society, 16641775. Chapel Hill: The University of North Carolina Press, 1978.

Kloek, Els, Nicole Tweeuwen, and Marijke Huisman, eds. Women of the Golden Age: An international debate on women in seventeenth-century Holland, England, and Italy. Hilversum: Verloren, 1994.

Koehler, Lyle. A Search for Power: "The Weaker Sex" in Seventeenth-Century New England. Urbana,IL.: University of Illinois Press, 1980.

Kulikoff, Allan. The Agrarian Origins of American Capitalism. Charlottesville: University of Virginia Press, 1992.

Leder, Lawrence, Jr. Robert Livingston, 1654-1728, and the Politics of Colonial New York. Chapel Hill: University of North Carolina Press, 1961.

Lee, R.L. An Introduction to Roman-Dutch Law. Oxford: Oxford University Press, 1931.

Lerner, Gerda. The Creation of Patriarchy. New York: Oxford University Press, 1986.

Lovejoy, David S. The Glorious Revolution in America. New York: Harper and Row, 1972.

MacKinnon, Catherine. Feminism Unmodified: Discourses on Life and Law. Cambridge, MA., Harvard University Press, 1987.

Marshall, Sherrin, ed. Women in the Reformation and Counter Reformation. Bloomington: University Indiana Press, 1989. 
The Dutch Gentry, 1500-1560: Family, Faith, and Fortune. Westport, CT., Greenwood Press, 1987.

McCormick, Charles Howard._Leisler's Rebellion. New York: Garland Publishing, Inc., 1989.

Merwick, Donna. Possessing Albany, 1630-1710: The Dutch and English Experience. New York: Cambridge University Press, 1990.

Mook, Bertha. The Dutch Family in the Seventeenth and Eighteenth Centuries: An Explorative-Descriptive Study. Ottawa: University of Ottawa Press, 1977.

Morris, Richard B. Studies in the History of American Law, with Special Reference to the Seventeenth and Eighteenth Centuries. Philadelphia: J.M. Mitchell, 1959.

Narrett, David E. Inheritance and Family Life in Colonial New York City. Ithaca: Cornell University Press, 1992.

Nooter, Eric and Patricia Bonomi. eds., Colonial Dutch Studies: An Interdisciplinary Approach. New York, 1988.

Norton, Mary Beth. Founding Mothers and Fathers: Gendered Power and the Forming of American Society. New York: Knopf, 1996.

O'Callaghan, Edmund B. History of New Netherland or New York Under the Dutch. 2 vols. New York: D. Appleton, 1848.

Prior, Mary. Women in English Society, 1500-1800. New York: Cambridge University Press, 1985.

Reich, Jerome R. Leisler's Rebellion: A Study of Democracy in New York, 1664-1720. Chicago: Chicago University Press, 1953.

Seybolt, Robert Francis. Apprenticeship and Apprenticeship Education in Colonial New England and New York. New York: Teacher's College, Columbia University, 1917.

Showmaker, Robert B. Gender in English Society, 1650-1850: The Emergence of Separate Spheres?. London and New York: Longman, 1998.

Ulrich, Laurel Thatcher. A Midwife's Tale: The Life of Martha Ballard, Based on her Diary, 1785-1812. New York: Knopf, 1990. 
Good Wives: Image and Reality in the Lives of Women in Northern New

England, 1650-1750. New York: Vintage, 1991.

Van Deursen, Arie T. Plain Lives in a Golden Age: Popular culture, religion, and society in seventeenth-century Holland. Cambridge: Cambridge University

Press, 1981.

Van Doorsten, Jan. Ten Studies in Anglo-Dutch Relations. Leiden: Sir Thomas Browne Institute, at the University Press, 1974.

Van Rensselaer, Mariana G. History of the City of New York in the Seventeenth Century. 2 vols. New York: Macmillan, 1909.

Van Vloten, Jan. Het Nederlandsche Kluchspel van de 14e tot 18e eeuw. 3 vols. Haarlem, n.d.

Webb, Stephan Saunders. 1676: The End of American Independence. New York: Knopf, 1984.

Webb, Stephan Saunders. The Governors-General: The English Army and the Definition of the Empire, 1569-1681. Chapel Hill: University of North Carolina Press, 1979.

\section{Newspapers:}

De Bow's Review

New York Weekly Journal

\section{Secondary Sources: Articles and Papers}

Archdeacon, Thomas J. "The Age of Leisler-New York City, 1689-1710: A Social and Demographic Interpretation." In Aspects of Early New York Society and Politics. ed. Jacob Judd and Irwin H. Polishook. Tarrytown, N.Y.: Sleepy Hollow Restorations, 1974: 63-82. 
Bielinski, Stefan. "The Schout in Rensselaerswijck: A Conflict of Interests.” In $\underline{A}$ Beautiful and Fruitful Place: Selected Rensselaerswijck Seminar Papers. Albany: New Netherland Publishing, 1991: 3-12.

Biemer, Linda B. "Criminal Law and Women in New Amsterdam and Early New York." In A Beautiful and Fruitful Place: Selected Rensselaerswijck Seminar Papers. ed. Nancy Anne McClure Zeller. Albany: New Netherland Publishing, 1991: 73-82.

Bonomi, Patricia U. "The Middle Colonies: An Embryo of the New Political Order." Perspectives on Early American History: Essays in Honor of Richard B. Morris, New York: Harper and Row, 1973.

Carlson, Marybeth. “'A Trojan Horse of worldliness?': Maidservants in the burgher household in Rotterdam at the end of the seventeenth century." In Women of the Golden Age. ed. Els Kloek. Hilversum: Verloren, 1994: 87-95.

Carr, Lois Green and Lorena S. Walsh. "The Planter's Wife: The Experience of White Women in Seventeenth-Century Maryland." William and Mary Quarterly. 34 (October, 1977), 542-571.

Carter, Alice C. "Marriage Counselling in the Early Seventeenth-Century: England and the Netherlands Compared." In Ten Studies in Anglo-Dutch Relations, ed. Jan van Doorsten. Leiden: Sir Thomas Browne Institute, at the University Press, 1974: 94-127.

Christoph, Peter R. "Social and Religious Tensions in Leisler's New York," de Halve Maen. 67 (Winter, 1994), 87-92

“The Colonial Family: Kinship and Power." In A Beautiful and Fruitful Place: Selected Rensselaerswijck Seminar Papers. ed. Nancy Anne McClure Zeller. Albany: New Netherland Publishing, 1991: 111-118.

“Worthy Virtuous Juffrow Maria van Rensselaer." de Halve Maen 70 (Summer, 1997), 25-40.

Clark, Christopher. "Household Economy, Market Exchange and the Rise of Capitalism in the Connecticut Valley, 1800-1860." Journal of Social History. 13 (1979): 169-189.

Cohen, David Steven. "How Dutch Were the Dutch of New Netherland." New York History. 62 (January, 1981), 43-60. 
Cott, Nancy F. "Divorce and the Changing Status of Women in Eighteenth-Century Massachusetts." William and Mary Quarterly 33 (October, 1976): 586-614.

"Eighteenth-Century Family and Social Life Revealed in Massachusetts Court Records." Journal of Social History. 10 (1979): 20-42.

De Baar, Mirjam. "Transgressing Gender Codes: Anna Maria van Schuurman and Antoinette Bourignon as Contrasting Examples." In Women of the Golden Age, ed. Kloek. Hilversum: Veloren, 1994: 143-152.

Deker, Rudolf. "Children on their Own, Changing Relations in the Family: the Experiences of Dutch Autobiographers, Seventeenth to Nineteenth Centuries." In Private Domain, Public Inquiry: Families and Life-Styles in the Netherlands and Europe, 1550 to the Present. Hilversum: Verloren, 1996: 61-71.

"Women in Revolt: Popular Protest and Its Social Basis in Holland in the Seventeenth and Eighteenth Centuries." Theory and Society. 3 (May, 1987): 337-362.

Demos, John. "Demography and Psychology in the Historical Study of Family Life: A Personal Report." In eds. Peter Laslett and Richard Walls. Household and Family in Past Time: Comparative Studies in the Size and Structure of the Domestic Group over the Last Three Centuries in England, France, Serbia, Japan, and Colonial North America, with Further Materials from Western Europe. Cambridge: Cambridge University Press, 1972: 561-569.

Fabend, Firth Haring. “'According to Holland Custome': Jacob Leisler and the Loockermans Estate Feud." de Halve Maen. 1 (Spring, 1994), 1-8.

Folkerts, Jan. "Kiliaen van Rensselaer and Agricultural Productivity in His Domain: A New Look at the First Patroon and Rensselaerswijck Before 1664.” In $\underline{A}$ Beautiful and Fruitful Place: Selected Rensselaerswijck Seminar Papers. ed. Nancy Anne McClure Zeller. Albany: New Netherland Publishing, 1991: 295308.

Goebel, Julius, Jr. "The Courts and the Law in Colonial New York." In Essays in the History of Early American Law. ed. David H. Flaherty. Chapel Hill: University of North Carolina Press, 1969: 245-277.

Goodfriend, Joyce D. "The Dutch Colonial Legacy: 'Not Hasty to Change Old Habits for New." de Halve Maen. 65 (Spring, 1992): 5-9. 
"Writing/Righting Dutch Colonial History." New York History. 80 (Jan. 1999): 5-28.

Gowing, Laura. "Language, power and the law: women's slander litigation in early modern London." Women, Crime and the Courts in Early Modern England. Chapel Hill: University of North Carolina Press, 1994: 26-47.

Greven, Philip J. "Family Structure in Seventeenth-Century Andover, Massachusetts." William and Mary Quarterly. 23 (April, 1966), 234-256.

Gundersen, Joan R. and Gwen Victor Gampel. “Married Women’s Legal Status in Eighteenth-Century New York and Virginia." William and Mary Quarterly 39 (1982), 114-134.

Henretta, James. "Families and Farms: Mentalitié in Pre-Industrial America." William and Mary Quarterly 35. (1978): 3-32.

“The Transition to Capitalism in America." In The Transformation of Early American History: Society, Authority, and Ideology. eds. James Henretta, Michael Kammen, and Stanley Katz. New York: Knopf, 1991: 218-238.

Howard, Ronald W. "Apprenticeship and Economic Education in New Netherland and Seventeenth Century New York." In Education in New Netherland and the Middle Colonies: Papers of the $7^{\text {th }}$ Rensselaerwyck Seminar of the New Netherland Project. Albany: New Netherland Project, 1985.

Hufton, Olwen. "Women in Revolution, 1789-1796." Past and Present 53 (1971): 90108.

Johnson, Herbert Alan. "The Advent of Common Law in Colonial New York." In Selected Essays: Law and Authority in Colonial America. ed. George Athan Billias. Barre, MA.: Barre Publishing, 1965: 74-91.

“The Prerogative Court of New York, 1686-1776." In Essays on New York Colonial Legal History. ed. Herbert Alan Johnson. Westport,CT.: Greenwood: 1981: 55-105.

Jordan, Jean P. "Women Merchants in Colonial New York.” New York History. (October, 1977): 412-439.

Klein, Milton M. "New York in the American Colonies: A New Look." In Aspects of Early New York Society and Politics, eds. Jacob Judd and Irwin H. Polishook. Tarrytown: Sleepy Hollow Restorations, 1974: 8-28. 
Laurence, Anne. "How Free were English Women in the seventeenth-century." In ed. Kloek. Women of the Golden Age, 127-135.

Leuker, Maria-Teresa. "Women's sphere and honour: the rhetorical realism of Bredero's farces, A response to Giesla van Oostveen." In Women of the Golden Age. ed. Els Kloek. Hilversum: Veloren, 1994: 65-69.

Levy, Barry J. "'Tender Plants: Quaker Farmers and Children in the Delaware Valley, 1681-1735." Journal of Family History 3 (Summer, 1978), 116-135.

Lodwick, Charles. "New York in 1692." Collections of the New York Historical Society. 2d ser. vol. 2. New York: 1842.

Lynch, Katherine A. "The Family and the History of Public Life.” Journal of Interdisciplinary History (1994): 665-684.

Main, Gloria. “Gender, Work, and Wages in Colonial New England." William and Mary Quarterly, 51 (January, 1994): 39-66.

Marshall, Sherrin. "Protestant, Catholic, and Jewish Women in the Early Modern Netherlands." In Women in Reformation and Counter-Reformation Europe: Private and Public Worlds, ed. Sherrin Marshall. Bloomington, Indiana: Indiana University Press, 1989: 120-139.

Matson, Cathy. "The 'Hollander Interest' and Ideas about Free Trade in Colonial New York: Persistent Influences of the Dutch, 1674-1764." In A Beautiful and Fruitful Place: Selected Rensselaerswijck Seminar Papers. ed. Nancy Anne McClure Zeller. Albany: New Netherland Publishing, 1991: 251-268.

McKinley, Albert E. “The English and Dutch Towns of New Netherland.” American Historical Review. 6 (1900): 1-18.

McMahon, Sarah F. "Laying Foods By: Gender, Dietary Decisions, and the Technology of Food Production in New England Households, 1750-1850.” In Early American Technology: Making and Doing Things from the Colonial Era to 1850. ed. Judith McGaw. Chapel Hill: University of North Carolina Press, 1994.

Merwick, Donna. "Dutch Townsmen and Land Use: A Spatial Perspective on Seventeenth-Century, Albany, New York." William and Mary Quarterly 37 (January, 1980): 53-78. 
"Review of A Dutch Family in the Middle Colonies." Journal of American Ethnic History. (Summer, 1995), 77-80.

Moller, Herbert. "Sex Composition and Correlated Culture Patterns of Colonial America." $\quad$ William and Mary Quarterly. 34 (March, 1945): 113-153.

Murrin, John M. "English Rights as Ethnic Aggression: The English Conquest, the Charter of Liberties of 1683, and Leisler's Rebellion in New York." In Authority and Resistance in Early New York. eds. William Pencak and Conrad Edik Wright. New York: New York Historical Society, 1988: 56-94.

Narrett, David E. "Dutch Customs of Inheritance, Women, and the Law in Colonial New York City." In Authority and Resistance in Early New York, eds. William Pencak and Conrad Wright. New York: New York Historical Society, 1988: 2755.

"Men's Wills and Women's Property Rights in Colonial New York." In Women in the Age of the American Revolution, eds. Ronald Hoffman and Peter J. Albert. Charlottesville: University of Virginia Press, 1989: 91-133.

Norton, Mary Beth. "Eighteenth-Century Women in Peace and War: The Case of the Loyalists." William and Mary Quarterly. 33 (1976), 386-409.

"Gender and Defamation in Seventeenth-Century Maryland." William and Mary Quarterly. 44 (1987): 3-39.

“The Evolution of White Women's Experience in Early America." American Historical Review. 89 (June, 1984): 593-619.

"The Myth of the Golden Age." In Women of America: A History. eds. Carol R. Berkin and Mary Beth Norton. Boston: Houghton Mifflin, 1979: introduction.

Prior, Mary. "Freedom and autonomy in England and the Netherlands: Women's Lives and Experiences in the seventeenth-century, A response to Anne Laurence." In ed. Kloek. Women of the Golden Age, 137-140.

Rink, Oliver. "The People of New Netherland: Notes on Non-English Immigration to New York in the Seventeenth-Century." New York History. 62 (1981): 5-42.

Roodenburg, Herman T. "The Autobiography of Isabella de Moerloose: Sex, Childrearing, and Popular Belief in Seventeenth-Century Holland." Journal of Social History. (Summer, 1985), 517-540. 
Rosen, Deborah A. "Mitigating Inequality: Women and Justice in Colonial New York." In Women and Freedom in Early America, ed. Larry D. Eldridge. New York: New York University Press, 1997: 313-329.

Seybolt, Robert Francis. "The Evening Schools of Colonial New York City." In Fifteenth Annual Report of the New York State Education Department. 1 (1919): 630-645.

Segalen, Mertine. "The House Between Private and Public: A Socio-historical Overview." In Private Domain, Public Inquiry: Families and Life-Styles in the Netherlands and Europe, 1550 to the Present. ed. Anton Schuurman and Pieter Spierenburg. Hilversum: Veloren, 1996: 240-253.

Sneller, Agnes. "Reading Jacob Cats." In Women of the Golden Age, ed. Els Kloek. Hilversum: Veloren, 1994: 21-34.

Spalletta, Matteo. "Divorce in Colonial New York." The New York Historical Society Quarterly 39 (October, 1955): 422-440.

Spies, Marijke. "Not every contradiction is a contradiction, A response of Lia van Gemert." In Women of the Golden Age. ed. Els Klock. Hilversum: Verloren, 1994: 51-53.

Stewart, Abigail J. “Toward a Feminist Strategy for Studying Women's Lives.” Women Creating Lives: Identities, Resilience, and Resistance. eds. Carol E. Franz and Abigail J. Stewart and Boulder, CO.: Westview Press, 1994.

Syrett, Harold C. "Private Enterprise in New Netherland." William and Mary Quarterly. 11 (October, 1954): 536-550.

Tebbenhoff, Edward H. "Tacit Rules and Hidden Structures: Naming Practices and Godparentage in Schenectady, New York, 1680-1800.” Journal of Social History (Summer, 1985), 567-585.

Van der Heijden, Manon. "Secular and Ecclesiastical Marriage Control: Rotterdam, 1550-1700.” In ed. Anton Schuurman and Peiter Spierenburg. Private Domain, Public Inquiry: Families and Life-Styles in the Netherlands and Europe, 1550 to the Present. Hilversum: Veloren, 1996.

Van der Woude, A.M. "Variations in the size and structure of the household in the United Provinces of the Netherlands in the seventeenth and eighteenth centuries." In Household and Family in Past Time. ed. Peter Laslett. Cambridge: Cambridge University Press, 1972: 299-318. 
Van Deursen, Arie T. "Jacob Cats and the married woman, A response to Agnes Sneller." In Women of the Golden Age. ed. Els Kloek. Hilversum: Veloren, 1994: 35-38.

Van Oostveen, Giesla. "It Takes All Sorts to Make a World: Sex and Gender in Bredero's Farce of the Miller." In Women of the Golden Age, ed. Els Kloek. Hilversum: Veloren, 1994: 55-64.

Van Zwieten, Adriana E. “'[O]n her woman's troth”: Tolerance, Custom, and the Women of New Netherland.” de Halve Maen 55 (Spring, 1999): 3-14.

Varga, Nicholas. "Mary Spratt Provoost Alexander." Notable American Women, 16071950. ed. James Edward. Cambridge, MA.: Harvard University Press, 1971: 35-36.

Voorhees, David W. "“how ther poor wives do, and are delt with': Women in Leisler's Rebellion,” de Halve Maen 70 (Summer, 1997): 41-48. "Leisler's Pre-1689 Biography \& Family Background.” de Halve Maen. 62 (December, 1989), 1-7.

“The Execution: Jacob Leisler, traitor or martyr?" Hudson Valley Magazine (February, 1990): 25-28.

Wright, Langdon G. "Local Government and Central Authority in New Netherland." The New York Historical Society Quarterly 57 (January, 1973): 7-29.

\section{Secondary Sources: Dissertations and Papers}

Goodfriend, Joyce D. “'Too Great a Mixture of Nations': The Development of New York City Society in the Seventeenth Century." Ph.D. diss., University of California at Los Angeles, 1975.

Shattuck, Martha Dickinson. "A Civil Society: Court and Community in Beverwijck, New Netherland, 1652-1664.” Ph.D. diss., Boston University, 1993.

Voorhees, David W. "'In Behalf of the true Protestants religion': the Glorious Revolution in New York.” Ph.D. diss. New York University, 1988. 
Maika, Dennis. "Citizenship in Seventeenth-Century Manhattan: The Local Politics of Inclusion in the Changing World of Atlantic Commerce, 1657-1675." unpublished paper, Omohundro Institute of Early American History and Culture. Worcester, MA., June, 1998.

Maika, Dennis. "Commerce and Community: Manhattan Merchants in the Seventeenth Century.” Ph.D. diss., New York University, 1995.

Gherke, Michael. “Beyond a Woman's Sphere: Public Lives of Elite Women in Eighteenth-Century Virginia." unpublished paper, Duquesne History Forum, (October, 1996).

"Margaret Hardenbroeck: New York Merchant." unpublished paper, First Annual West Virginia University History Forum, 1997.

"Wives as Family Financial Managers in New Netherland and SeventeenthCentury New York." unpublished paper, Omohundro Institute of Early American History and Culture. Austin, TX.: 1999.

Snyder, Terri Lynn. “'Rich Widows Are The Best Commodity This Country Affords': Gender Relations and the Rehabilitation of Patriarchy in Virginia." Ph.D. diss. University of Iowa. 1992. 